

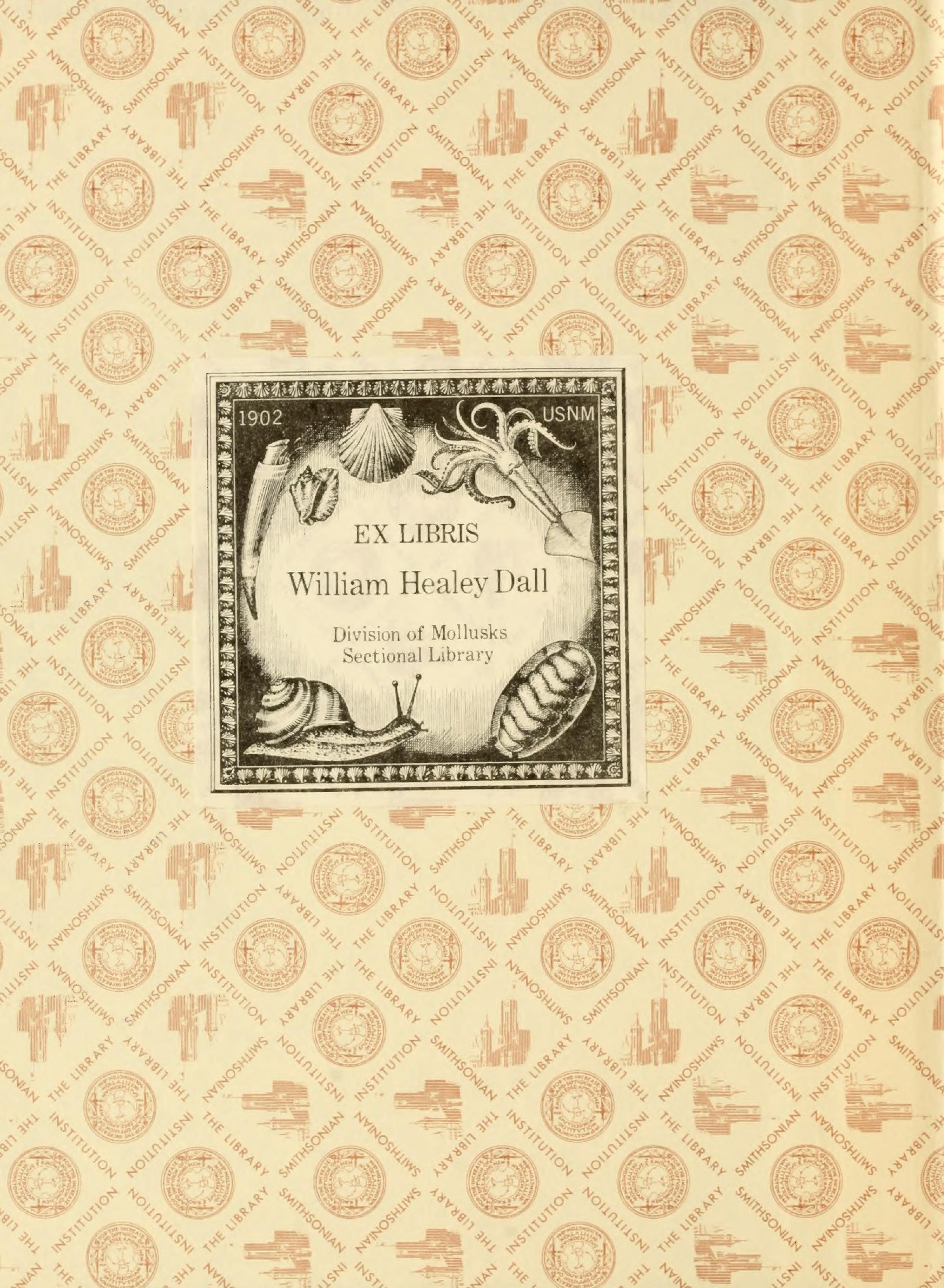




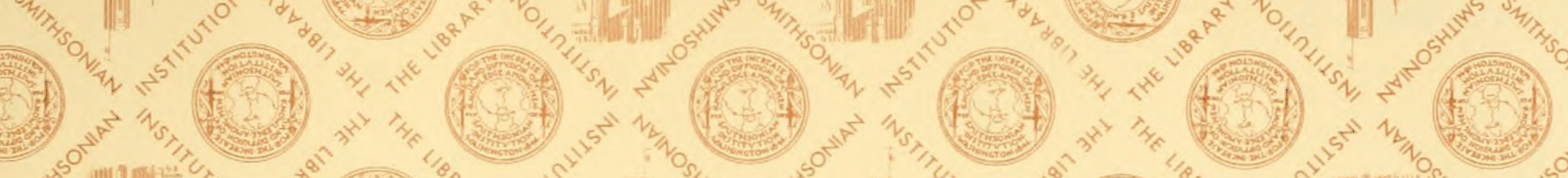

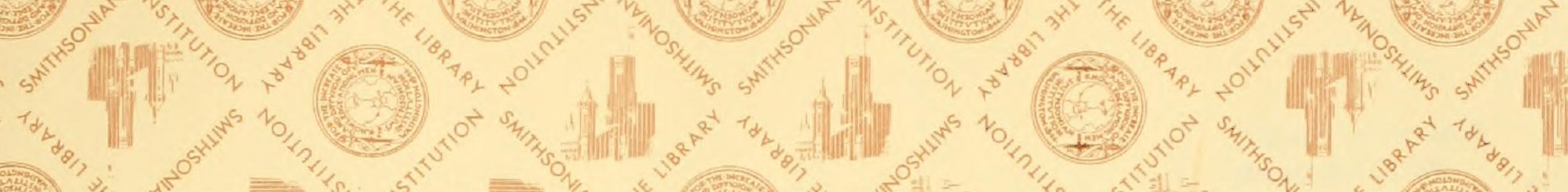
(5i)

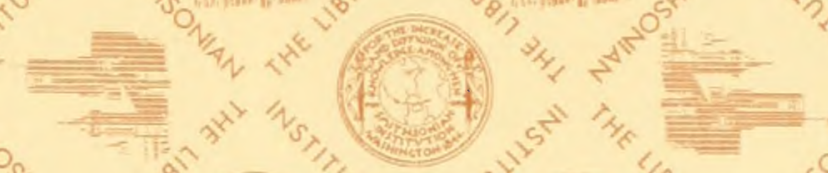

$\left(\frac{1}{2}\right)$

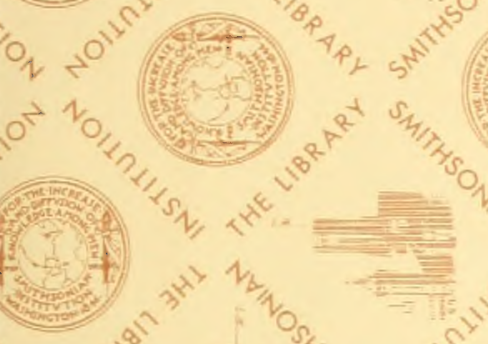
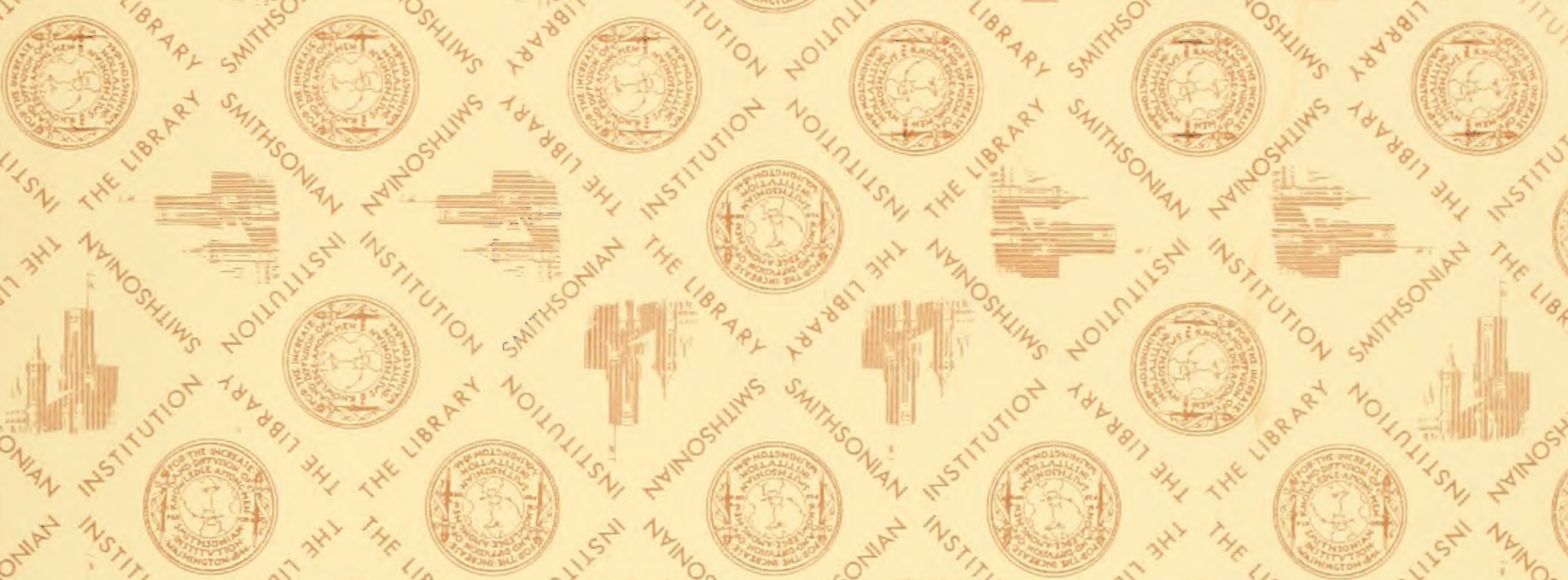

$\left(\frac{3}{2}+\frac{1}{2}\right)$

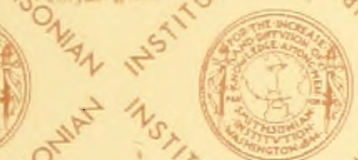
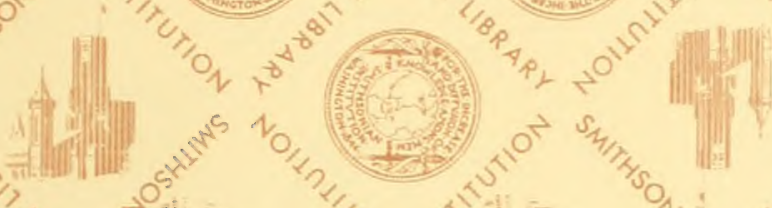

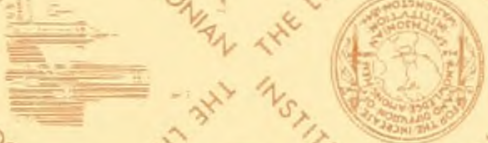

(II)

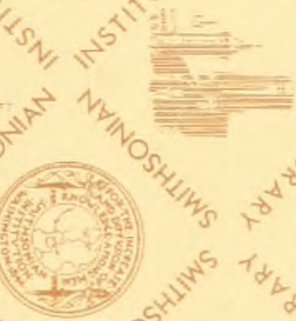

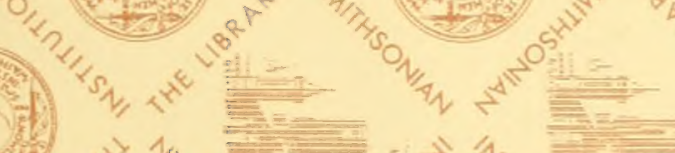
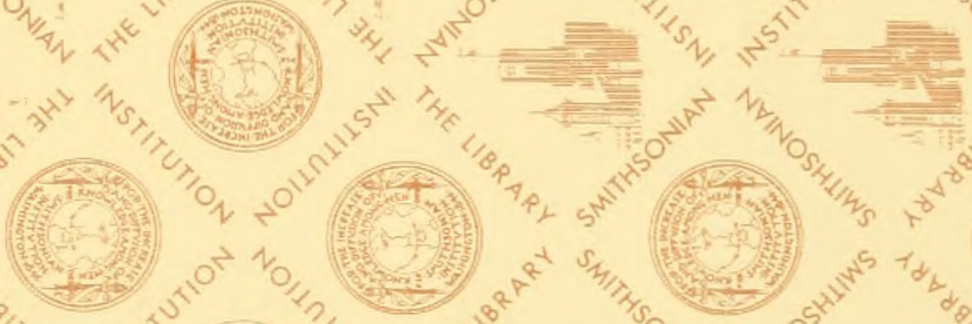

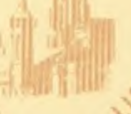

(fint)

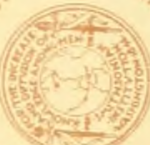

$\mathrm{O}_{1}$

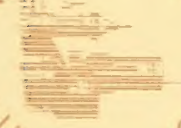

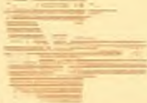

$\left(\frac{3}{4}+\frac{1}{4}\right.$

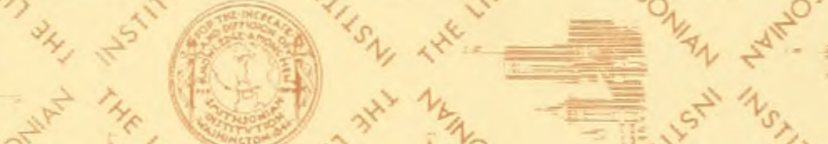

$\underline{\underline{n+1}}$

(f) $\left.\frac{1}{2}, 2\right)$

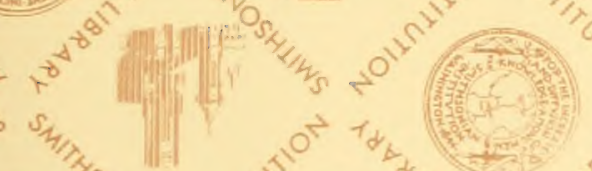

i.

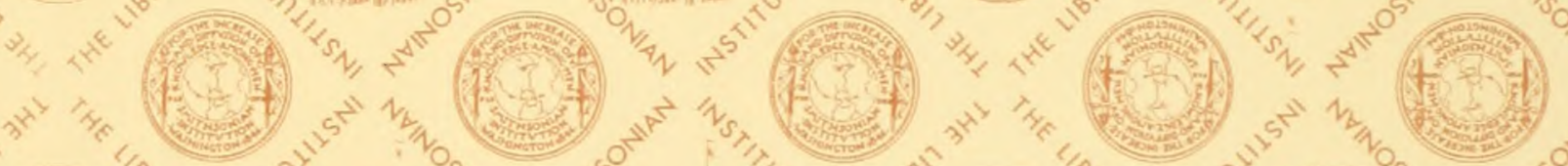

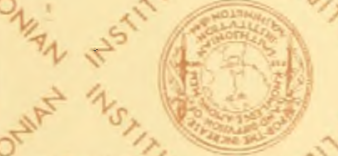

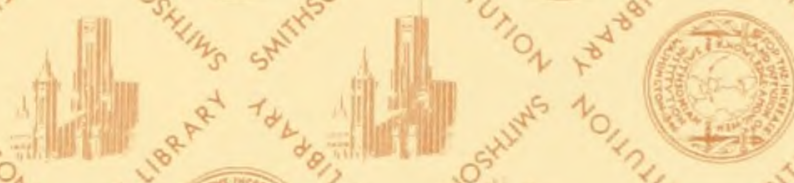
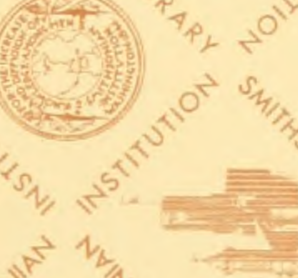

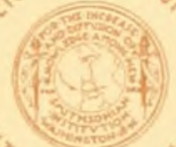

保-

(fer.

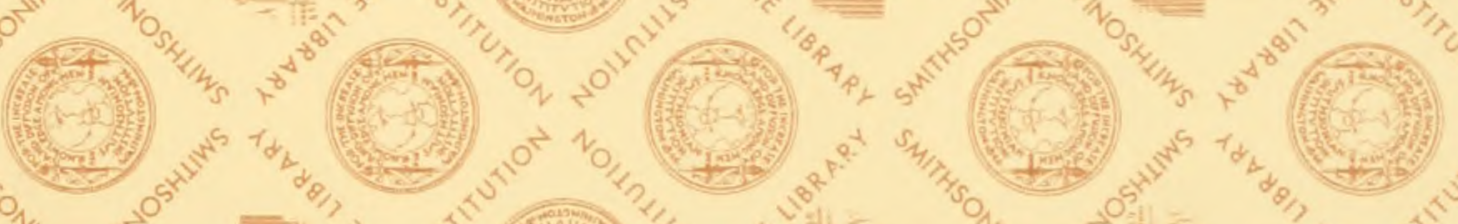

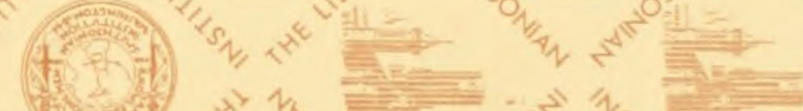

$\left(3-\frac{1}{3}\right)$ 



$$
L \text { - odhner }
$$

Division in iviollualss

Soctional Librory 



\section{RESULTS}

OF

DR. E. MJÖBERGS

\section{SWEDISH SCIENTIFIC EXPEDITIONS}

TO

AUSTRALIA $1910-1913$

XVII.

\section{MOLLUSGA \\ Division of Mollusing \\ Sectional Library \\ BY}

NILS HJ. ODHNER

STOCKHOLM

WITH 3 PLATES AND 5 I FIGURES IN THE TEXT

COMMUNICATED APRIL 25TH 1917 BY HJ. THÉEL AND E. LÖNNBERG

STOCKHOLM

ALMQVIST \& WIKSELLS BOKTRYCKERI-A.-B.

BERLIN

R. FRIEDL ÄNDER \& SOHN

11 CARLSTRASSE
LONDON

WILLIAM WESLEY \& SON

28 ESSEX STREET. STRAND
PARIS

LIBRAIRIE C. KLINCKSIECK

11 RUE DE LILLE 

KUNGL. SVENSKA VETENSKAPSAKADEMIENS HANDLINGAR. Band 52. N:o 16.

\section{RESULTS}

$\mathrm{OF}$

DR. E. MJÖBERGS

\section{SWEDISH SOIENTIFIO EXPEDITIONS}

TO

AUSTRALIA 1910-1913

XVII.

MOLLUSGA

BY

NILS HJ. ODHNER

STOCKHOLM

WITH 3 PLATES AND 51 FIGURES IN THE TEXT 

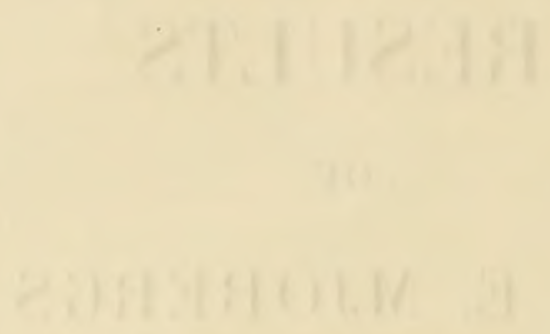

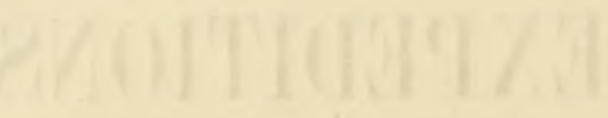
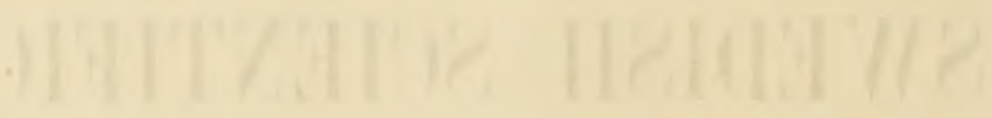


\section{Introluction.}

The present publication deals with all the abundant material of marine, as well as land and fresh-water, mollusea that was collected during Dr. MJöвERG's two journeys to Australia in the years 1911-13. As these expeditions were directed to regions of Australasia of the fauna of which but little was previously known, the publication of their malacological results will certainly be of scientific value. The collections not only contain new forms, but also contribute to give a more complete knowledge of the distribution of the animals in question, and, further, they have been, as far as possible, utilized in order to increase our knowledge of the morphology of many little studied mollusca. It is only to be regretted that in some cases too scanty material has been collected and that the collections are not so prolific in an oecological respect as they would have been if combined with information as to the habits and occurrence of the animals, as well as with notes on the local conditions; such accounts would have been very desirable, especially for the land mollusca.

The marine fauna from the regions of the Indian Ocean has been the object of continuous research in numerous more or less comprehensive publications, and the literature which it is necessary to deal with in studying mollusca from these regions is very scattered and difficult of survey. This inconvenience is increased by the fact that both the descriptions and the figures given by the authors often suffer from many deficiences; the latter are sometimes so unsatisfactory and reproduce characteristics so unessential that identification is sometimes quite impossible. Some of the authors seem only to have had before their eyes the object of establishing a lot of new forms without taking pains to give them the scientific value that they can only acquire by careful characterization. By such neglect considerable difficulties are placed in the way of subsequent identification, an experience often encountered in dealing with the present material. When the determinations have seemed uncertain, I have given a figure of the form in question or a description of its characteristies or of the points distinguishing it from the type to which it has been referred. In other doubtful cases I have preferred to establish a form as new rather than refer it to some previously described, but insufficiently characterized, species.

For every species of the collection I have stated not only the number of specimens collected, but also the maximum dimensions attained in each locality. By 
doing so one gains on the one hand the possibility of judging of the frequency of the species, on the other, a means of comparing its size with that attained in other localities. Generally, however, in faunistic works the lists of species contain only the bare names and the localities, though the value of the works would be considerably enhanced if the number and maximum dimensions of the specimens were added - something which would present no difficulty.

An especially critical explanation I have considered to be necessary for the family of Chamidae, and I have devoted considerable attention to this entire group, as the views generally accepted hitherto about the habitual characteristics and the delimitation of species within this group seemed to me to require a revision. The results of this inquiry will be published separately later on, but the most important ones are shortly cited here, and as a result of these studies the new genus $P$ seudochama is now introduced.

Other more comprehensive anatomical studies have been devoted to Chamostrea plicifera n. sp., Madrella fermuinosa and Atopos (Prisma) australis (?), and shorter accounts of the organization have been given, among others, for species of the genus Microcystis, Macrochlamys suturalis n. sp., and Silala wilcoxi.

Among new or otherwise interesting forms mentioned in this work may be named some land mollusca from (Queensland, which present a rery interesting support. for the theory (previously advanced on the basis of the geographical distribution of the mollusca) ${ }^{1}$ of a connection between the Australian continent and New Guinea on the one hand and New Zealand on the other. Thus a new species of the genus Chloritis has been described, which shows typical characteristics of the animal, but in its shell recalls a Cristigibba, a genus hitherto known as limited to New Guinea. Another interesting form of land mollusca confined to both regions, namely a specimen of the imperfectly lnown genus Atopos, has also a place in the collections and has been anatomically examined. Of the little known genus Hedleya (Fam. I'upinellidac), hitherto represented by a single specimen, a new species has been found.

Mr. CH. Hedley has pointed out ${ }^{2}$ that besides the tertiary land bridge between Australia and New Guinea, by means of which a part of the recent fauna of Queensland immigrated, also another land connection existed, connecting Australia with Tasmania and New Zealand with New Guinea during an earlier epoch (the mesozoic time). From this time probably dates the presence of, among others, the genus Flammulina, the distribution of which comprises Eastern Australia, Tasmania, Lord Howe's Island, New Guinea, New Caledonia and New Zealand. Of this genus a new species was collected in tropical Queensland farther towards the north than ranges the general distribution of the genus, namely on the top of Bellenden Ker, 4,000 feet, where this species may perhaps be considered a relic, having found in the more temperate climate on the mountain favourable conditions for its continued existence under the tropical latitude of Northern Queensland. With this theory agrees the

1 CrI. Hedery, On the origin of the land-snail fauna of Quecnsland, Australia. Nautilus, Yol. 6, 1893.

2 The evolution of the Queensland coast. Address by the president. Rep. Austral. Assoc. for Adrancement of Science, Vol. XII, Brisbane 1909, p. 330. 
fact that the single species of the genus from New Guinea, described by HEDLEY (1897) as $F$. abdita, was found at a height of 12,200 feet.

Whether the influence of the tertiary land bridge between Northern Australia and New Guinea may be traced in the present distribution of even the marine mollusca is a question that Mr. HEDLEY has drawn attention to, but it is not possible to answer it until more comprehensive investigations have given a more complete material of facts. On the one hand, there occur a great many mollusca both on the east and the west coasts of Australia simultaneously, for which reason the Torres Straits seem to have formed the way by which their migration took place. It may, however, on the other hand, be questioned whether Torres Straits, the shallowest part of which does not exceed seven fathoms in depth, was really used as passage by all the mollusca of north-west Australia, which also have a distribution on the eastern coast. Some for which an eastern origin is probable, such as Cerithiopsis crocea and Gena strigosa might have existed on the north-western coast long before the formation of the Torres Straits. Of special interest in this respect are the genera Chamostrea ${ }^{1}$ and Ephippodonta, which are lacking on the Queensland coast but appear on S. E. Australia on the one hand and N. W. Australia on the other, though in different species, it is true. There seems to be also some possibility that the forms in question might have spread, on the contrary, along the south and west coasts of Australia.

As to the composition of the marine fauna of N. W. Australia, the present collections make evident that the chief part of its constituents have a more or less extended range within the Indian Ocean. About three-fourths of them are confined to the area between Africa and the Philippines, and only one-fourth are limited to the coasts of Australia, such as the species of Pectunculus and Cardita, Chione peronii, Turcica maculata, Vermetus novachollandiae, Strombus campbelli, Voluta oblita.

The problem of the relations of the molluse fauna confined to the Australian continent has received from the present collections a paleontological contribution, as there were found some specimens of extinct land mollusea belonging to genera of which a few are not represented in Australia at present, but which show undoubted affinity to forms belonging to surrounding districts. They were collected (July 1913) in dark caves in the chalky ground at Chillagoe, North Queensland, and comprise the following new forms: Planispira praehadra, Microcystis antiqua, Hypselostoma australis, Aphanoconia extincta, and Omphalotropis minuta. Further, there were found some specimens of Microphyura microdiscus, a small shell described by BAVAY (1908) from the north coast of New Guinea. According to Dr. MJöBerG, the caves at Chillagoe are excavated in the cretaceous rocks, and are consequently of tertiary age; and the mollusca found in them are with certainty relics from this epoch. Unfortunately no detailed accounts have been given by Dr. MJöBERG. 'These finds, therefore, can only be simply mentioned here as facts which it is hoped will lead to more com-

1 Ch. albida IsAmanck is recorded from N. S. Wales, Victoria and Tasmania, New \%ealand and Chatam Island (Hutros 1885, Proc. Linn. Soc. N. S. W., Vol. LX). 
prehensive and productive investigations on the interesting history of the Australian land molluse fauna.

The total number of species of mollusca collected by Dr. MJörkrG and mentioned in this publication amounts to 292, including 36 new species or varieties, distributed as shown in the following surwey:

\begin{tabular}{|c|c|c|c|c|c|c|c|c|c|c|}
\hline \multicolumn{3}{|c|}{ Marine } & mollusea & from & Western & Australia & 219 & thereof & new & 20 \\
\hline \multicolumn{3}{|l|}{, } & , & 。 & Wastern & s & 3 & " & , & \\
\hline \multicolumn{3}{|c|}{ Land and fresh-water } & , & , & Western & s & 15 & " & " & \\
\hline 3 & \& & $=$ & , & $"$ & Eastern & 。 & 50 & s & , & \\
\hline Fossil & land & & $\Rightarrow$ & . & 8 & $"$ & 6 & " & 8 & \\
\hline
\end{tabular}

Of the Western Australian marine mollusca the collections from the shores of Broome are enumerated separately as being of less value, because they comprise numerous shells obtained from the inhabitants and therefore of somewhat uncertain locality.

'The Fastern Australian localities where land mollusca were collected are situated in the northern and southern regions of Queensland, and of their more exact geographical position may be given the following accounts:

Atherton, Herberton, Evelyne, Cedar Creek, Malanda and Bellenden Kier are situated south, and Chillagoe sonth-west of Cairns in North Queensland;

Christmas Creek, Glen Lamington, and Mount Tambourine, lie in South Queensland, south of Brisbane;

Coleman River debouches into Carpentaria Gulf on the west coast of York Peninsula.

Most of the figures of the three plates reproduced in the present publication are from photographs made by the author and retouched with well-known ability by Mr. G. LiLjevill. All the text figures, as well as figs. 68 - 70 of Pl. 2, have been drawn by the author.

To Mr. CH. Hedley, Sydney, I am under great obligations for much valuable advice and for kind assistance in controlling my identifications of some forms which were impossible to determine with certainty by the aid of literature only, as well as for his great kindness in sending me material for comparison of a great many of Australian mollusca. I am also indebted to Prof. A. Wirés, Uppsala, and Prof. A. Wicmans, Leiden, for their kindness in helping me in special cases. 


\section{A. Marine Mollusca.}

\section{Mollusca from the shores of Broome.}

Pinna bicolor Chennitz, var. A great many specimens of this species were taken on the muddy shores of Broome, the largest one measuring $22 \mathrm{~cm}$ in length. The colouration, consisting of dark radiating stripes, corresponds to that of the typical P. bicolor (figured by REEve, Conch. Icon. 11, fig. 17) but the shape differs in its straighter, obtusely truncated and not slowly curving posterior margin. The specimens are like some from Madagascar collected by Dr. KAUDERN; an especially characteristic feature are the sinuous squamular scars, which give the longitudinal ribs an imbricate appearance. Traces thereof, together with distinct squames, are present in the typical $P$. bicolor, judging from specimens in the Swedish State Museum. The Australian form is only somewhat darker than that from Madagascar and shows confluent rays, especially on the inner shell surface; at the posterior margin there is, however, a lighter zone, where they appear clearly.

P. nigra Cnennitz, 1 shell of $29 \mathrm{~cm}$, interiorly dark brown with the muscular scar causing a curving-out of the pallial line, exteriorly with obscure broad longitudinal ridges, with dense squamular sears.

P. chemnitzi Hanler, 1 sh., 1. $206 \mathrm{~mm}$.

Ostrea hyotis Livise, 1 sh., diam. (breadth) $17 \mathrm{~cm}$.

0. imbricata LAMARck, $1 \mathrm{sh}$, diam. (breadth) $12 \mathrm{~cm}$.

On these Ostrea shells there were attached several mollusca, such as Septifer, Chama, Sigarelus.

0. inermis SOW IRB Y, some worn shells, max. 1. $62 \mathrm{~mm}$.

0. ordensis SAville-Kent. Broome, on twigs of White Mangrove (Avicennia officinalis), many sps, max. l. about $15 \mathrm{~mm}$. This small-sized form was discovered by SAVLLE-KENT in Cambridge Gulf and briefly mentioned by him in 1889 (Proc. Roy. Soc. Queensland, 6, p. 224-5). He deseribed it in 1891 and later 
on gave some illustrations of its mode of attachment and growth ('The Naturalist in Australias, London, 1897, p. 249-50).

Pteria (Margaritifera) maxima Jumksos, many specimens, max. diam. (height) $21 \mathrm{~cm}$; one valve with a P'innotheres attached on the inside and covered by its margaritaceous layer. About this species see further below (p. 15).

Malleus albus LAMARCK, 4 shis, max. 1. $254 \mathrm{~mm}$.

Modiola philippinarum HANLEY, 2 shs, max. 1. $51 \mathrm{~mm}$.

M. plumescens DUNKER, 1 right valve, 1. $40 \mathrm{~mm}$. Though worn and without the characteristic cuticular hairs, it proves by comparison with a specimen from Cape Jaubert to belong to this species because of its rough growth strigations.

Anomia (Patro) elyros GrAY, 9 upper valves, max. $1.62 \mathrm{~mm}$, which seem to agree best with the figure of $A$. elyros in REeve (Conch. Icon. 11, 1859, fig. 3).

Spondylus victoriae SowERry var. wrightianus Crosse, I sh., 1. $110 \mathrm{~mm}$ (enclosed the spines). For this species ef. E. A. Surtr, 1884 (Rep. Zool. Coll. JAlert.).

Arca navicularis BRUGüì̀e, l right valve, worn, $1.38 \mathrm{~mm}$.

A. granosa Linné. In mangrove mud on the shore, many specimens, max. I. $44 \mathrm{~mm}$, and one shell thrown up on the beach $\left({ }^{21} / 7\right.$ 1911). The specimens differ in showing a more produced posterior shell-end from fig. 12 in REEvE's Conch. Icon. 2, 1843. Further the present specimens differ from the type in the acuminated corner between the posterior and inferior margin, through which the form becomes more oblique and the radiating ribs running to this point broader than the remaining ones (in the typical form, the broadest ribs are in the median part of the shell); the ribs above the corner are, further, lower than those of the typical form and have no linobs; the umbones are somewhat narrower and higher; the breadth of the hinge margin is greater than in the type. The number of ribs is 20 , and $\mathrm{nr} 13-15$ is the angular rib. 'This variety seems to be most like A. cuneata REEve (fig. 37, Conch. Icon. 2) which is stated to occur at Zanzibar. Lamy (1907) finds that sles spécimens qui portent ce nom d'A. cuneala dans les collections du muséum [Paris], et qui proviennent d'Australie et de Ceylan, sont simplement des échantillons de granosas (p. 213), an opinion that makes me more convinced in my view that the present specimens belong to the same species. - Its distribution ranges from Bombay to the Philippines and Japan (LYNGE 1909).

A. decussata Sowrrby, 1 sh., 1. $33 \mathrm{~mm}$.

Pectunculus radians LAstrok, 3 shs, max. $1.15 \mathrm{~mm}$, show agreement with typical specimens from Australia in the State Museum.

Tridacna squamosa Lamarck, $1 \mathrm{sh}, 1.25 \mathrm{~cm}$.

Cardium elongatum Brugurìre, 1 sh., 1. $84 \mathrm{~mm}$. 
Jaubert.

C. multispinosum ReEve, 1 left valve, $1.35 \mathrm{~mm}$.

C. rugosum Lamarck, $1 \mathrm{sh}$, height $46 \mathrm{~mm}$, on the shore 90 miles $\mathrm{S}$. of Cape

Tellina ostracea HANLEY, 1 sh., 1. $26 \mathrm{~mm}$ (resembling fig. $124 b$ in ReveE's Conch. Icon. 17).

Psammobia coerulescens Lamarck, 1 sh., l. $44 \mathrm{~mm}$.

Asaphis deflorata Linnḱ, 1 sh. $1.61 \mathrm{~mm}$.

Cryptogramma squamosa Linné, 2 shs, max. $1.27 \mathrm{~mm}$.

Cytherea resticulata Sowerbx, 1 sh., 1. $113 \mathrm{~mm}$.

Chione berryi Deshayes, some shs, max. 1. $33 \mathrm{~mm}$.

Ch. peronii LaMiarck, 3 shs, max. 1. $34 \mathrm{~mm}$.

Artemis incisa ReEve, some single valves, max. 1. $49 \mathrm{~mm}$.

Tapes variegata SowErbY, many shs, with varying colouration, max. $1.34 \mathrm{~mm}$.

T. textrix Chennitz, I right valve, $1.29 \mathrm{~mm}$.

Venerupis subdecussata DeshaYes, 2 shs, max. 1. 27; h. 18.5; br. (both valves closed) $14 \mathrm{~mm}$. Both shells, which are somewhat different in shape, agree very well with the figures given by HEDLEr 1913 (Pl. XVI, figs. 27, 28).

Clementia papyracea GraY, 1 sh., 1. $38 \mathrm{~mm}$.

Mactra depressa Spenaler, I left valve, 1. $38 \mathrm{~mm}$.

M. antiquata SPENGLer, 1 sh., 1. $52 \mathrm{~mm}$.

Acmaea saccharina Linné var. stellaris QUor \& Gamard, 2 shells, max. I. $25 \mathrm{~mm}$; on the beach 90 miles $\mathrm{S}$. of Cape Jaubert, 1 sh., 1. $24 \mathrm{~mm}$. - The specimens quite correspond to the figures in PILSBRY, Man. of Conch. Vol. XIII, 1891, pl. 36, figs. 63,64 .

Glyphis jukesi ReEve, 1 sh., 1. $19.5 \mathrm{~mm}$.

Trochus niloticus Livné, 3 shs, max. h. $90 \mathrm{~mm}$.

T. architectonicus A. ADAMs, 7 shs, on the shore $\left({ }^{26} / 7\right), \max .1$. $35 \mathrm{~mm}$.

Euchelus atratus GMeLrN, 6 shs, max, h. $26 \mathrm{~mm}$.

Monodonta labio LinNé, 6 shs, on the shore, max. h. $28 \mathrm{~mm}$.

Turbo petholatus LINNÉ, 1 sh., h. $40 \mathrm{~mm}$.

T. porphyrites MARTYN var. porcatus REEVE, 2 sps on the shore $\left({ }^{26} / 7\right)$, max. diam. 25 $\mathrm{mm}$. In their rather strong spiral keels they most resemble 1 . porcatus REEVE (Conch. Icon. 4, fig. 52), but having feebler keels than this form they pass into $T$. versicolor REFVE (Conch. Icon. fig. 19).

K. Sv. Vet. Akat, Handl, Band 52. N:o 16. 
Nerita lineata Chemisz, $2 \mathrm{sps}$, on the shore $(15 / \mathrm{c})$, max. diam. $37 \mathrm{~mm}$; on the one specimen was attached an Ostrea (O. rosacea?) assuming as well the colouration as the sculpture of the Nerita. - The shore 90 miles S. of Cape Jaubert, 4 shs, max. d. $37 \mathrm{~mm}$.

N. polita Linné, 1 sh., l. $15 \mathrm{~mm}$.

N. chamaeleon LinNé, I sh., 1. $13 \mathrm{~mm}$; the shore 90 miles S. of Cape Jaubert, 4 shs, max. d. $16 \mathrm{~mm}$.

Natica conica LAMARCK, many shells and specimens on the shore, max. h. $36 \mathrm{~mm}$.

N. filosa Soveriy, 3 shs, max. h. $29 \mathrm{~mm}$.

Sigaretus planulatus RecLuz, Wollal telegraph station, 30 miles NE, 12 feet deep $(3 / 6), 1$ sp., 1. $11.4 \mathrm{~mm}$ (shell).

Cerithium morus LAMARCK var. patiens BAYLE, 1 sh., l. $18 \mathrm{~mm}$, among oysters on the shore $\left({ }^{23} / \%\right)$. The specimen closely resembles $C$. musivum Hombron \& JaCQUINOT (compare 'TrYon 1887, Man. of Conch, Vol. IX, pl. 24, fig. 47).

C. Corallinum Dufresne, many sps, on the shore $(15 / 6)$, max. h. $32 \mathrm{~mm}$. Like fig. 1 and 2, 'Taf. 39 in Kobelt 1898 (Martini \& Chemnitz, Conch. Cab. I: 26).

Cerithidea decollata LINNÉ, I sh., 1. $30 \mathrm{~mm}$.

Potamides (Tympanotonus) palustris LinNe, many shs, on the shore, max. l. $110 \mathrm{~mm}$.

P. (Terebralia) semitrisulcatus (BoIтLN) M̈̈rci, on the shore, I sp., h. $61 \mathrm{~mm}$.

Telescopium telescopium Linné, 1 sh., 1. $110 \mathrm{~mm}$.

Siliquaria ponderosa Mörci, 1 sh., about $27 \mathrm{~mm}$ in height; mouth about 10 $\mathrm{mm}$ in diameter.

Strombus campbelli Griffitir \& Prdaeon, 1 sh., h. 4 o mm. Corresponds to the figure in Tryon, Man. of Conch. VII, 1885, p. 115, pl. 5, fig. 46.

Strombus pacificus SWAINSON var,, 2 shs, max. 1. $71 \mathrm{~mm}$. Both specimens show the characteristic rifling on the inside of the lip in which it differs from $S$. auris dianc; further the spire is comparatively much produced, so that it agrees entirely with ReEve's fig. 35 (Conch. Icon. 6, 1851). 'The colour, however, is uniformly milky within the aperture, and on the body whorl the outer colouring (brown spots and lines) shines through the thin callus spreading over this portion; typically this part is brownish.

Eulima martinii A. Adums. On the shore 90 miles S. of Cape Jaubert, 3 shells, max. h. $25 \mathrm{~mm}$. 
Dolium olearium Lamarck, on the shore, 6 shs, max. $118 \mathrm{~mm}$.

D. costatum MwNKE, on the shore, 1 sh., h. $72 \mathrm{~mm}$.

Cassis coronulata Soweriy, 2 shs, max, 1. $78 \mathrm{~mm}$.

Nassa livida GrAY (= unicolorata KIENER), on the shore, many shs and sps, $\max$. h. $33 \mathrm{~mm}$.

N. monile KIENER (var.), on the shore (15/6), many sps, max. h. $13.5 \mathrm{~mm}$. Colour, form and sculpture varying. A few somewhat shorter and broader sps with sharper ribs belong to var. acuticosiata MonTRAILLE.

Cancellaria asperella LAMARoK, 2 shs, max. h. $36 \mathrm{~mm}$.

Cypraea thersites Gaskoin, many shs, max. 1. $56 \mathrm{~mm}$.

C. suhviridis REEvE, 4 shs, max. 1. $38 \mathrm{~mm}$.

C. caurica Linné, 1 sh., 1. $40 \mathrm{~mm}$.

C. errones Linné, 2 shs, max. 1. $28.5 \mathrm{~mm}$, on the shore $(26 / 7)$.

Planaxis sulcata Bors, on the shore, many sps, max. h, $17.5 \mathrm{~mm}$.

Tritonidea (Cantharus) fumosa Dillwys, 2 sps, on the shore $(23 / 6)$, max. h. $27.5 \mathrm{~mm}$. Yellowish red aperture margins and a trace of a whitish peripheric band on the last whorl are the specific characteristics met with also in these specimens (cf. 'Tryon, Man. of. Conch. Vol. III, 1881, pl. 73, fig. 247).

Pyrula tessellata КовеLt, 2 shs, max. 1. $57 \mathrm{~mm}$.

Megalatractus aruanus Linné, 5 shs, $\max .1 .60 \mathrm{~cm}$, br. $28 \mathrm{~cm}$; together with egg capsules (cf. Hedley 1900, Stud, on Australian Moll. part II, Proc. Linn. Soc. N. S. IV., Vol. 25, p. 508, pl. 25 fig. 18).

Turricula corrugata LAMARCK, 1 sh., h. $35 \mathrm{~mm}$.

Ovula volva Liñé. 1 sh., 1. $108 \mathrm{~mm}$.

Murex monodon ReEve, l sh., on the beach, h. $90 \mathrm{~mm}$.

M. tribulus Linné, 3 shs, max. 1. $83 \mathrm{~mm}$.

M. cervicornis LamarcK, 1 sh., 1. $42 \mathrm{~mm}$.

M. brevispina Lamarck, 1 sh., 1. $58 \mathrm{~mm}$.

Terebra duplicata Linné, 2 sps, max. 1. $70 \mathrm{~mm}$.

Oliva scripta LAMARCK, I sp., 1. $36 \mathrm{~mm}$, crawling on the shore (16/5).

Ancillaria cingulata Sownrmy, S. of Broome, 1 sh., h. $47 \mathrm{~mm}$.

Conus capitaneus LiNnÉ, 2 shs, 1. $60 \mathrm{~mm}$. 
C. omaria Hwass var. colubrinus LaMarck, 2 shs, max. $1.47 \mathrm{~mm}$.

Melo diadema Lamarck, 10 shs, max. J. $36 \mathrm{~cm}$, br. $24 \mathrm{~cm}$.

Voluta reticulata REEVE, 2 shs, max. h. $90 \mathrm{~mm}$.

V. oblita E. A. Smitir 1909 (=V. norrisii Soweriy, non GraY; REeve, Conch. [con., 6, fig. 15), 2 shs, max. h. 67 mm. Both specimens have strong spines on the shoulder of the whorls (about 12 in one turn). The smaller shell is exactly like the fig. 15 given by REEVE, and somewhat broader than the larger one, which, however, even in its colouration with indistinet brown lines shows that it belongs to the present species. Mr. Surm has shown that $V$. norrisii of GRAI is a distinct species, not identical with the present form. According to Sum, $V$. oblita is recorded from N. IV. Australia and from King George's Sound (cf, also HEDLEY 1916).

Bulla tenuisculpta n. sp. (Pl. 1, figs. 1-3). Shell ovoid, everywhere with well rounded outlines, rather thin and shining, except for fine, sparse, engraved, somewhat undulating lines towards the base and around the apex, and thin longitudinal cords most noticeable towards the apex. Apical perforation moderate with some spiral striations. Colour marbled with small white and reddish brown confluent dots and four revolving series of indistinct, somewhat dark, clouds. In the interior of the aperture the colouring shines through. Columella slightly sinuous with a thin callous margin spreading a fragile layer over the parietal wall to the apex. Maximum dimensions: height 33, breadth 22, diameter of apical perforation $1.5 \mathrm{~mm}$.

This species seems to be closely related to $B$. quoyi GRAY in the presence of its fine impressed striae towards the base, but as these occur also around the apex and its size is more considerable than that of $B$. quoyi, which is, further, more solid, I have considered the present form to be a distinct species. Seren empty specimens were found on the shore of Broome.

Octopus membranaceus Quor \& Gamard, Wollal telegraph station, 30 miles NE., 12 feet $(3 / 6), 2 \mathrm{sps}, \max .1 .25 \mathrm{~mm}$.

Tonica truncata Sowerby. Broome, low water, on the shore $\left({ }^{26} / 7\right), 3 \mathrm{sps}$, resembling in colour and sculpture the figure in Rervi (1S47, Pl. 16, fig. 93) and Pilsbry (1893, Pl. 40, figs. 1, 2). Colour light grayish, girdle with brown stripes radiating from each valve. Valves of a yellowish gray colour with dark gray longitudinal stripes, on the lateral areas often confluent into spots that may stretch over the whole valve; anterior valve minutely punctate all over by the presence of resthetic eyes.

Max. length $35 \mathrm{~mm}$, breadth $25 \mathrm{~mm}$.

The valves exhibit the peculiarity of being separated laterally by interjacent snibs from the girdle. In the anterior valve there are 8 slits, in the median 1 , and in the posterior 14. 'There seems to be only a slight difference in the form of the valves, these being in the present specimens more than usually extended laterally. The species has been previously recorded from the Philippines (cf. PILSBRY 1893). 
2. Mollusca from the Pearl Banks off Cape Jaubert.

\author{
a. Lamellibranchia. \\ FAM, LIMIDAE.
}

Lima squamosa Lamarck. 45 miles W. S. IV. off Cape Jaubert, $48-60$ feet $(8 / 7), 5$ sps, max. 1. $42 \mathrm{~mm} ; 42$ miles $\mathrm{W}$. S. IV., 60-72 feet $\left({ }^{11} / 7\right), 5$ sps, max. 1.23 $\mathrm{mm}$. - The present specimens differ from the Mediterranean form only in somewhat feebler longitudinal ribs and smaller scales. MeLvide \& STANDEN (1899) trace the species from the regions of the Indian Ocean to Torres Straits: \& We have traced it across the Isthmus of Suez to Red Sea waters, then along the coasts of India and Ceylon, eastward, uninterruptedly» (p. 182). In the collections of the Swedish State Iuseum the species is represented from Singapore and Osaka. Also Lynge (1909) records it from Singapore. E. A. Suiru (1885, Rep. Challenger) mentions it from the Philippines, the Louisiade Archipelago and New Zealand, and Liscrke discusses its distribution in Japan.

L. fragilis Chemnitz. 42 miles W. S. W., 42 feet $(5 / 7), 1$ sp., $1.8 .5 \mathrm{~mm} ; 45$ miles IV. S. IV., 70-72 feet $\left({ }^{14-16 / 8}\right), 4 \mathrm{sps}$, max. $1.12 .5 \mathrm{~mm}$. - The species has a wide distribution from Suez and Persian Gulf to the Philippines, and the Society Islands (Lynge 1909; Melvilu \& Standen 1906, v. Martens 1886); IV. Australia (HEDLEY 1916).

\title{
FAM. OSTREIDAE'.
}

Ostrea vitrefacta Soweris 45 miles W. S. W., 72-80 feet $(3,14 / 7)$, many sps, max. $1.12 \mathrm{~mm}$, from spines of Echinids. In shape the specimens resemble 0 . mytiloides Lamarck (ReEve, Conch. Icon. 18, fig. 3), but as the shell borders are set with teeth all round as in specimens of $O$. vitrefacta from Madagasear which have been compared, the present form may be considered identical with that species. From their attached position on the Echinid spines they have acquired a stretched form, tapering towards the apex. - The species is previously known from Mauritius (ReEve, Conch. Icon. 18, 1871).

0. rivularis (Gould) Lischke. 42 miles $\mathrm{W}$. S. W., $70-72$ feet $\left({ }^{25} / 5\right)$, many sps, max. 1. $18 \mathrm{~mm}$; 45 miles W. S. W., 48-72 feet, 4 sps, max. 1. $20 \mathrm{~mm}$. LrNat (1909) mentions the species from Gulf of Siam. It is, besides, known from Japan.

O. imbricata LAMArck. 45 miles W. S. W., 66 feet $(29 / 5), 1 \mathrm{sp}, 1.100 \mathrm{~mm}$. It shows in the colour (light reddish spots and stripes) and in its sculpture (radiating ridges here and there rising to tubular scales) close agreement with figure 36 in REEve's Conch. Icon. 18, 1871. LYNGE (1909) considers it to be a variety of $O$. hyotis and gives its distribution from the Persian Gulf to Japan, Java, and New Guinea; it occurs also on Queensland (HEDLEY 1910). 
NILS IIJ. ODIINER, MOLLUSC.1.

?0. rosacea Chlunitz. Some small specimens of a bright crimson colour which were attached on Trochus fenestralus and other shells may be referred to this species as their exterior characteristics agree best with REEVE's fig. 46 of this form. REEVE gives Lord Hood's Island as locality.

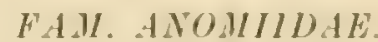

Anomia sol ReEve. 45 miles W. S. W., 60 feet $(13 / 8), 1$ sp., max. dian. (breadth) $28 \mathrm{~mm}$. It differs from the figure given by REEvE (Conch. Icon. 11, 1859, fig. 4) in its silvery hyaline colour, and from a specimen from Madagascar in its narrower radiating ridges. LYNGE (1909) mentions it from the Gulf of Siam and gives some particulars as to synonyms and distribution. HEDLEY (1899) records it from Funafuti.

\section{FAM PECTINIDAE}

Pecten squamatus Gmelin. 42 miles W. S. W., 72 feet $\left({ }^{2}, \mathrm{c}\right), 1$ sp., diam. 45 mm. Like fig. 82 in REEve (Conch. Icon. 1853) in colour and sculpture; the upper valve with 5 squamous ribs, between which run 3 minutely spinose riblets; on the inferior valve there is about each second riblet spinulose. The specimen differs from REEVE's figure in its strikingly unequal ears, in which characteristic it resembles P. squamosus Gmelin; the anterior ear is much larger than the posterior one. REeve (Conch. Icon. 8, 1853) gives the Philippines as the locality of this species, DAUTzENBLRG \& BAVAY (1912) record it from S. of 'Timor, Japan and 'T'ahiti.

P. asperrimus Lanarck. 45 miles W. S. W., 60 feet $\left({ }^{29} / 5\right), 1 \mathrm{sp}$, diam. $55 \mathrm{~mm}$; 72 feet $\left({ }^{16} / 8\right), 1 \mathrm{sp}$, diam. $33 \mathrm{~mm}$. The species differs from $P$. auslralis in the existence of many equal-sized intercostal lines between and on the sides of the ribs; in $P$. australis, which may perhaps be a variety of the present species, ${ }^{1}$ there is one narrow line on each side of the ribs. - According to Hutrox (1885) this species is distributed on the coasts of Australia, Tasmania, and New Kealand (cf. Heder 1916).

P. australis Soweriz. 45 miles W. S. W., $60-72$ feet $\left({ }^{16} / 7\right), 3$ sps, max. 1.50 mm; 42 miles W. S. W., 70 feet $(\pi / 5), 1$ sp., 1. 4 mm. Distribution: Swan River, Vest Australia (RELve 1853, Conch. Icon. 8; Hediry 1916).

P. dringi Rever. 42 miles W. S. W., 42 feet $(5 / 7), 1 \mathrm{sp}$, diam. $23 \mathrm{~mm} ; 45$ miles W. S. W., 66 feet $\left({ }^{15} / \mathrm{r}\right), 1 \mathrm{sp}, 1.15 \mathrm{~mm}$. In form and sculpture the specimens are like REEVE's fig. 152 a (Conch. Icon. 8), but the colour is brick-red, without any drawings; the right (inferior) valve is paler. - LYNGE (1909) and DAUTZENBERG \& BAVAY (1912) comprise this species in $P$. fulvicostalus and give its distribution from Red Sea to N. and E. Australia and Paumotu Isl.

P. fulvicostatus Adans \& ReEve. 45 miles $W$. S. W., 60 feet $\left({ }^{13} / 7\right), 3$ sps, max. diam. $50 \mathrm{~mm}$. They correspond to RELVE's figure 152 a but are larger in size. According to LYNGE (1909), this form is synonymous with $P$. dringi (cf.above).

1 E. A. SMiti (1885), Ioxge (1909), and Dautzexberg \& Bayay (1912) consider them synonymous. 
P. difformis n. sp. (PI. 1, figs. 4, 5). Shell highly compressed, of a broadly ovate shape, truncated above by a straight extended hinge line. Anterior margin nearly perpendicular, with a slight sinuation above the middle, inferior one well rounded and posterior slightly curving. No distinct ears on the upper valve. Umbones triangularly projecting somewhat behind the middle of the hinge line, defined by a feeble radiating impression behind and a more distinct one in front. Inferior valve somewhat smaller and flatter than the upper one, with a deep byssal sinus, bounded by a straight anterior margin of the valve, with a few denticles above and an S-formed curvation of the lower margin of the wing. Sculpture of both valves consisting of very fine radiating lines, more conspicuous towards the margins; the wing of the inferior valve with stronger radiating liræ. Colour hyaline with radially stretched snowy dots spread all over. Maximal dimensions: height $10.2 \mathrm{~mm}$; breadth (from anterior to posterior margin) $8.9 \mathrm{~mm}$; thickness of the closed shell $1.9 \mathrm{~mm}$. Locality: 45 miles W.S. W., 6 small sps with dried animals, attached to the basal part of a T'urbinaria.

Though certainly not full-grown, the largest of these specimens has such a peculiar form, aberrant from the normal shape of the Pectinidae, that it must be established as a new species. Above all the absence of ears is a remarkable characteristic. Compared with $P$. madreporarum PETiT, another species living on corals, the new form is broader at the hinge line, is less oblique and far less tumid, and it has a different, much finer, sculpture.

\section{FAM. SPONDYLIDAE.}

Plicatula australis Lamarck. 42 miles IV. S. W., 70 feet $\left({ }^{30} / 5\right), 2$ sps, max. 1. $28 \mathrm{~mm} ; 45$ miles $\mathrm{IV}$. S. W., $48-72$ feet $\left({ }^{8} / 7\right), 4$ sps, max. $1.35 \mathrm{~mm}$. 'The specimens agree in their small red-brown dots all over the shell with fig. $10 c$ in REEve, Conch. Icon. 19, 1873. It has been recorded from the Philippines and from Queensland (LŸNE 1909, HEDLEY 1910).

\section{FAM.AVICULIDAE.}

Fteria (Margaritifera) maxima Jameson. 42 miles W. S. W., 70 feet, 1 sp. $\left({ }^{25} / 5\right)$, 1. $33 \mathrm{~mm}$; 45 miles W. S. W., 60-140 feet, many sps, max. $1.70 \mathrm{~mm}$ (young). It was not until 1901 that this form, the largest mother-of-pearl oyster, was established, by Jameson, as a distinct species. Previously it was included under $P$. margaritifera of Linne. The distinctions between the two species were first pointed out by SAvitekent, though he thought the present form to be the typical $P$. margaritifera and named the second species Avicula cumingii RELVE. JAMESON shows, however, that the present species is not identical with the Linnean type, from which it differs in being larger and flatter and having a longer hinge line, with which the posterior margin makes an acute or right angle. Further, the border of the nacre on the inside usually has a white or golden colour, whereas in $P$. margaritifera it is 
dark green. Besides these characteristics pointed out by JAMESON, there are observable discrepancies between the two species also in the shape of the muscular sears on the interior side of the shell. The specimens from Cape Jaubert differ from equalsized ones of $P$. margarilifera in having the upper part of the muscular scar produced and relatively broad, its length equalling a third of the total length of the scar, and its breadth, in old specimens, about $\frac{2}{3}$ of that of the scar. In P. margaritifera, on the contrary, the upper lobe of the scar is considerably smaller, forming in length less than a third of the total length and in breadth about half that of the scar. 'This difference in the scars corresponds to a somewhat different arrangement of the muscles of the animal. In $P$. maxima the foot retractors have been inserted at the middle of the adductor, and the upper part of the latter has been produced dorsally. In $P$. margaritifera, on the contrary, the retractors are inserted with their chief part above the middle of the adductor, which thus projects beyond them only with a small portion. The same shape of the muscular scar is also found in specimens from East Indies, which in other respects exhibit the characteristies of $P$. maxima, so that there is no doubt that the two forms are specifically distinct.

According to JAMESON, the present species occurs on the north and north-east coast of Australia, on the coasts of N. Guinea, Borneo, Philippines, and Salomon Islands; W. Austratfa; (HEDLEx 1916).

Pteria (Electroma) zebra ReEve (Pl. 1, figs, 6-8). 42 miles W. S. W., 42 feet $(5 / 7), 2$ sps, max. 1. $6.8 \mathrm{~mm}$, on Lylocarpus phoeniceus (Busk); 45 miles W. S. W., 60 feet $(1 / \%)$, many sps, max. 1. $8 \mathrm{~mm}$, on Plumularia badia Kirchenp., and 1 small sp., 1. $3.5 \mathrm{~mm}$ in a large colony of Ophiodes dicholomus (ALLM.); 66 feet $\left({ }^{15} / 7\right), 1$ sp., 1. 11.2 $\mathrm{mm}$, on Plumularia badia; 72 feet $(25 ; 5)$, many sps, max. $1.5 .7 \mathrm{~mm}$, on Lylocarpus phoeniceus. - The species is figured by REEve (Conch. Icon. 10, 1857, Avicula, sp. 36) and, recently, by LYNGE (1909, Pl. 11, fig. 16-18). It occurs on the Maledives, the Gulf of Manaar and the Gulf of Siam, Port Elizabeth, Queensland, and Tasmania (Lynge 1909); W. Australia (HEDLEY 1916).

It is a very remarkable fact that the beautiful lineation of the specimens found off Cape Jaubert accords very closely with the substratum, so that the brown lines are narrower and somewhat denser in specimens attached to Lylocarpus (fig. 6) and coarser in those on Plumularia (fig. 7). Further, the ground colour of the shell is light yellowish in the former specimens, pure opaque white in the latter, where all the pigment has been concentrated in the brown stripes, thus giving them a deeper brown tint. The distribution of the colour, judging from these two types takes place during growth. In both cases the nepionic shell is colourless, and the brown stripes do not begin to appear until after attachment. No reciprocal change of colour between the two varieties, resulting in specimens on Plumularia with narrow, and in such on Lylocarpus with broad, lines has been observed in the present material, nor any stages of transition between the two types. This case of variation, consequently, seems to be due to the direct influence of the substratum, and the adaptation of the mussel to it may be explained by the presumption of the susceptibility of its 
epithelium to light influences and a faculty of reacting on them in such a manner that the pigment is distributed according to the distribution of light and shade in the closest surroundings. This faculty of reacting is to be regarded as a normal characteristic of the present molluse. That a single specimen has acquired an aberrant colouration (fig. S) may be explained on the supposition that it has remained unaffected by its surroundings; its epithelium has been sblind and the pigment has been diffused uniformly. 'The occurrence of this specimen, which may be considered as badly adapted in comparison with the others, does not speak in favour of the view that natural selection in this case was the regulator of the variation. The present form would be an interesting subject of experiment with respect to the theories mentioned.

Avicula straminea Dunker. 45 miles W. S. W., 60 feet $\left({ }^{17} / 7\right), 1$ sp., $1.12 \mathrm{~mm}$ from a colony of Ophiodes dichotomus (ALLM.); 72 feet $\left({ }^{16 / 7}\right), 1 \mathrm{sp}, 4.50 \mathrm{~mm}$. The specimens agree very well with the description and the figure given by DUNKER (Martini \& Chemitz, Conch. Cab. 7:3, 1872, Tab. 9, Fig. 1). It is distributed in the Indian Ocean (DUNKER).

Perna vulsella Lamarck (Pl. 1, figs. 9, 10). 42 miles W. S. IV., 70-72 feet $\left({ }^{26} / 5\right)$, many sps, max. 1. $52 \mathrm{~mm} ; 45$ miles W. S. W., 60-80 feet, many sps, max. 1. 68 $\mathrm{mm}$. The specimens differ from the Madagascar ones in their less obvious radiating rays and their more distinct, often strongly developed, posterior wing and sinuous posterior margin, which gives them some resemblance to $P$. fimbriata REEve (Conch. Icon. 11, 1858, fig. 23). Both the shape and the colour are, however, subject to great variation, and as the soft parts of the animals do not exhibit any differences, both the Madagascar and the Australian form are here referred to the same species. The distribution of the species comprises Natal, seas of India and America (cf. Bartsch 1915); Clessin 1891 (MARTine \& Chemintz, Mallacea) further records it from West-Africa (Loanda), and Nebvilu 1909 from Nauritius and the Philippines.

Malleus regula Fonsiit. 42 miles $W$. S. W., 72 feet $\left({ }^{2} / 6\right), 1$ sp., $1.90 \mathrm{~mm} ; 45$ miles, 70 feet, I sp., $1.14 \mathrm{~mm}$. The species is easily recognized by its longitudinal rib on the inside of the shell. Distribution from the Red Sea and the Persian Gulf to the Philippines, Japan, and S. Australia (Lrnge 1909); IV. Australia (Hedeer 1916).

\section{FAM. MYTILIDAE}

Mytilus horridus DunkFr. 45 miles $W$. S. W., 60 feet $\left({ }^{29} / \mathrm{s}\right), 1 \mathrm{sp}, 1.70 \mathrm{~mm}$. Its form agrees best with $M$. tortus of REEve (Conch. Icon. 10, 1857, fig. 6), which E. A. Snitu 1885 considers identical with M.horridus, and has the umbones turned to the left in relation to the posterior shell portion, further the whole shell (not only the posterior half, as in REEvE's figure) is covered with thick epidermal hairs, short at the umbones, prolonged towards the hinder margin, which are dentated in their ventral edge. Its long dorsal margin somewhat recalls a Pleria. - The species has been recorded from Cape York and the Philippines (E. A. Smrry 1885). 
Septifer bilocularis Linvt, var. 45 miles W. S. W., 80 fect $(29 / 6), 1$ sp., 1. 25.5 $\mathrm{mm} ; 60-72$ feet, many sps, max. 1. $45 \mathrm{~mm} ; 48$ feet $(8 / 7), 4$ sps, max. 1. $40 \mathrm{~mm}$; 42 miles IV. S. WV. 70 feet $\left({ }^{25} / 5\right)$, many sps, max. $1.35 \mathrm{~mm}$. The shells (fig. 2) are red and green in colour, like Mytilus nicobaricus or M. kranssi of REEve (Conch. Icon. 10, figs. 42 and 40); the colours may be more or less marbled.

With respect to the great polymorphism of the Septifer bilocularis series, I hold it to be of great scientific import to state which of the forms included in the species may be the typical one. The original specimen of Lrswe had not been hitherto identified with certainty. As it belonged to the Museum Ludovica Ulricae, I hoped to find it in the collections of Linnean conchylia at Uppsala. Through the kindness of Professor A. WinḱN, I am able to give a description and some figures of, as it seems, LINNÉ's original specimen of this species (fig. 1). Professor WinÉ

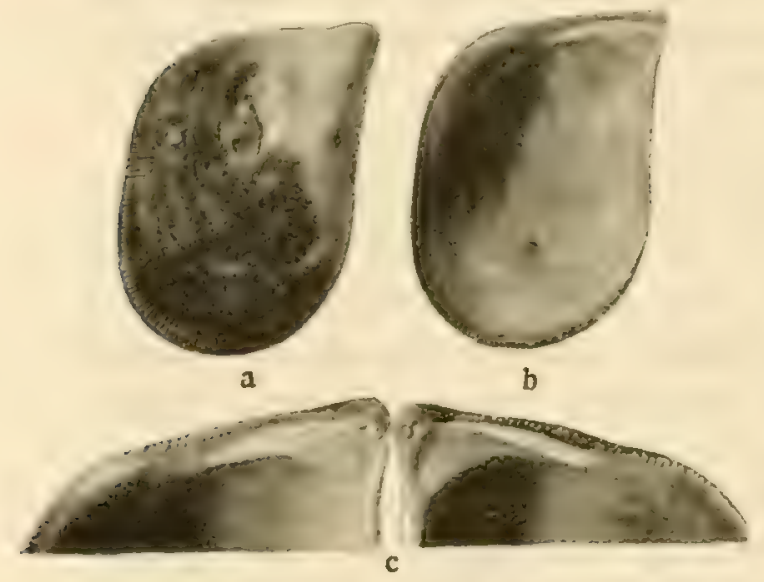

Fig. 1. Septifer bilocularis LINNÉ. LinNé's original of Myeilus bilocularis, Syst. Nat. X, p. F05. a right, $b$ loit valvo; slightly enlarged; $c$ umbonal parts with septa and hinges, $\times 2$.

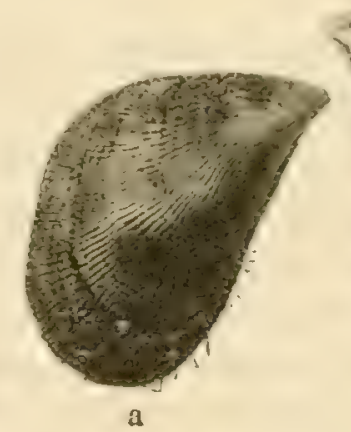

a

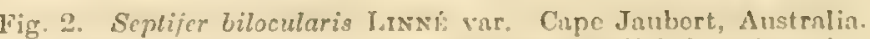
$a$ right, $b$ left valve, $c$ nnothor left vnlvo; slightly enlarged.

communicates the following remarks on the shell: „On account of the defective labelling in earlier times it is not absolutely certain that the specimen is the same as that described by Linnk. The labels originate from TiunBend, the printed one from a later time. LiNe mentions that his M. bilocularis is to befound in M(useum) $\mathrm{L}_{(\mathrm{u}-}$ dovicae) U(lricae). This museum was inherited by King Gustaf IV Adolf and was presented by him to Uppsala, for which reason it is designated „Mus. Gust. Ad.» on the labels of TuUnBera. It can be shown that this collection was added to and altered during the period between LINNé's examination of it and its presentation to Uppsala; however, as only one specimen of $M$. bilocularis exists, it is, of course, very probable that this is really the one described by LinNé. It agrees with the description and is, like many others of the royal conchylia, carefully polished.s

The specimen (fig. 1), both valves of which are quite entire - only the ligament has been removed - has a total length of $33 \mathrm{~mm}$ at a height from dorsal to ventral margin of 21 and a crassitude of $16.5 \mathrm{~mm}$. Its outline is somewhat quadrangular, due to the high dorsal margin. The colour of its anterior and ventral part is, as 
Linné says (Syst. Nat. X, p. 705), whitish, with some violet flames towaris the umbones and some traces of a reddish-yellow tint at the ventral side, originally spread over this region. Its posterior and dorsal part is reddish brown, darker towards the margins. The interior is white in front and below, violet with a slight margaritaceous hue for the chief part, and reddish brown along the dorsal and posterior margins.

The original sculpture still appears clearly towards the margins (fig. 1 a) which are finely crenelated all round with fine and dense radiating lines entirely covering the shell.

The interior septum (fig. 1 c) is rather broad (its breadth exceeding its height) and of a white colour. Its inner edge is slightly concave below and has in its upper half an almost obsolete convexity, which is situated half-way between the umbo and the posterior end of the ligament; the edge passes - deseribing a very slight sinus - into a comparatively short subligamental crest. From the ligament furrow the shelf is separated by a slight rib, which runs from the hindermost tooth, tapering backwards.

There are three teeth in the left valve, the median of them being the largest, as well as the rear one in the right valve. These each form a somewhat irregular knob with two or three smaller swellings.

The present Australian form differs from the typical specimen of S. bilocularis in having a more attenuated umbonal part and a septum which is longer than it is broad, and has, generally, in its upper half, a distinct prominence, which is situated nearer to the umbo than to the posterior end of the ligament. Further, the shelf is not limited from the ligamental furrow in the same manner as in the type. The teeth are about three in number in each valve, and vary much in form and position. These characteristics, as well as the white colour of the shelf, seem to be fairly constant in the Australian form, judging from the material at my disposal. Whether they are so important as to justify us in distinguishing the present form as a distinct species is a question that I cannot decide, since I lack sufficient material of the typical form for judging of the constancy of the characteristics of the Linnean specimen. I think that the Australian form must at least be considered a special variety in the same respect as the Indian and Japanese form, which is characterized by a constantly bluish green septum, with a tooth-like projection of the edge.

Modiola philippinarum HANLEY. 45 miles W. S. IV., 72 feet ( $\left.{ }^{11 / 7}\right), 1$ sp., 1.65 $\mathrm{mm}$; 80 feet $\left({ }^{29} / \mathrm{6}\right), 1 \mathrm{sp}, \mathrm{l} .6 .3 \mathrm{~mm}$. The first specimen is like $M$. albicosla Lavarci but differs in its somewhat sharper prominent lines of growth and more stretehed upper margin, and it agrees with fig. 1 in REEve (Conch. Icon. 10, 1858). In the second specimen the cuticular hairs are scanty, elongated, with short distant branches. The colour is red with a white costa. From M. plumescens it differs in its higher, rising upper margin and in its sharp concentrical folds, which are obsolete in front and begin to appear on the diagonal costa. Distribution: Red Sea and Persian Gulf to Japan, Torres Strait and Queensland (LrNGE 1909); IV. Australia (HEDLEY 1916). 
M. plumescens Dunker (Pl. 1, fig. 11). 42 miles $\mathrm{II}^{\text {. S. }} \mathrm{W}$., 42 feet, 1 sp. $(5 / 7)$, 1. $35 \mathrm{~mm}$; 45 miles W. S. W., 84 feet $(15 / 7), 10$ sps, max. 1. $7 \mathrm{~mm}$. Though the first specimen is in no other respect unlike the European M. barbala than that it has a longer upper margin, which forms a sharp angle to the hind margin, it must be referred to the present species, which is very like $M$. barbala but is distinguished from it by most authors. In its long ascendant dorsal line it is more similar to the figure given by Clessin (Mantine \& Cinematz, Conch. Cab. 8: 3, fig. 8, 9, Taf. 33) than to the specimen figured by LYNGE (1909, I'ab. II, fig. 13, 14). The prominent angle is certainly a variable characteristic. The young specimens from 84 feet in depth have dense but yet simple hairs and a greenish colour. For the synonymy and distribution (Java to Viti und Samoa Isl.) see LYNGE, 1909.

Modiolaria cumingiana (Dunker) Reeve. 45 miles IV. S. IV., 72 feet $(14 / 7$ ) from the mantle of ascidiae, $1 \mathrm{sp.,} 1.26 .7 \mathrm{~mm}$. The shell differs somewhat in shape from the figure given by REEVE (Conch. Icon. 10, pl. IX, fig. 63), but the sculpture and colour are typical. The form is rhomboidal and the length nearly twice the breadth; a prominent diagonal thick costa runs from umbo to posterior inferior angle; the anterior and the posterior area are radiately sculptured, the former with $S-10$ rather distant flattened ribs, the posterior one with denser similarly flattened ones about 18-20 in number (thereof about 5 or 6 in front of the diagonal costa); the median area is smooth, but finely and indistinctly radially striated. The umbones are rather prominent, but a little retracted from the anterior margin. Colour horny greenish brown. Inferior margin convex, slightly sinuous at the boundary rays of the lateral areas. The inside is simply margaritaceous with translucent striation.

M. cumingiana differs from M. impacta HERMANN in its more lengthened shape, and in the nature of its sculpture, the anterior rays of $M$. impacta being granular, here smooth. From 1I. cuncala GoutD it is distinguished by the number of radiating cords, which in that species are anteriorly 16, posteriorly 17 (BARTSCII 1915). 'The present species has a distribution from the Red Sea all round the coasts of Australia and far beyond them to Natal and Japan (LYNGE 1909).

M. miranda E. A. Sмiтr, 1884 (Rep. Zool. Coll. Alert). 42 miles W. S. W., 70 feet $\left({ }^{25} / \mathrm{s}\right), 1 \mathrm{sp}, 1.5 .2 \mathrm{~mm}$. This species, which was first found in Dunda Strait by the Alert expedition, was recently recorded by LYNGE(1909)from the Gulf of Siam. It is easily recognized by the fine concentric lines covering all the shell and crossing the radiating ribs, making them granulose. The median area is even, fincly reticulated. Colour green or red, with red zones.

Lithodomus gracilis Pribiper. 45 miles W. S. W., $48-70$ feet, boring the pearl mussle shells $\left({ }^{9} / 7\right), 2$ sps, max. $1.34 \mathrm{~mm} ; 42$ miles $W$. S. W., 70 feet $\left({ }^{26} / 5\right)$, 2 sps, max. 1. $40 \mathrm{~mm}$, deeply bored down in the pearl mussle shells. 'Ihe shells show the characteristic typical of this species, the striated area being extended 
farther towards the posterior end than it is in the West Indian L. niger D'ORBIGNY, a difference between these very similar species pointed out by LYNGE 1909, who gives its distribution from the Red Sea and Zanzibar to China, 'Torres Strait, and Tahiti. Hede ex (1916) records it from W. Australia.

L. reticulatus Dunker. 45 miles $\mathrm{IV}$. S. IV., 48 feet $\left({ }^{16} / \mathrm{r}\right)$, boring in a pearl mussle shell, $1 \mathrm{sp} ., 1.20 .5 \mathrm{~mm}$. The present specimens agree very well with the figure given by Dunker (Martini \& Chemnitz, Conch. Cab. 1882, Tab. 5 fig. 9, 10) and show the characteristic porous or reticulated crust covering the upper hinder part of the shell and projecting beyond its posterior end. DUNKkr (1882) mentions the species from Java(?).

\section{FAM. ARCIDAE.}

Arca navicularis Bruguike. 42 miles W. S. W., 70 feet $\left({ }^{30} / 5\right), 1$ sp., 1. 23 mm; 45 miles W. S. W., 60-70 feet, 5 sps, max. 1. 80 , L. 34, thickness $37 \mathrm{~mm}$; another sp., 1. 68, h. 35, br. $36 \mathrm{~mm} ; 48$ miles W. S. W., 140 feet, 1 sp., 1. $40 \mathrm{~mm}$. The dimensions given illustrate the variation in form of the species in this locality: even in the position of the umbones and the sculpture of the area there is great variety. 'They agree in most points with $A$. navicularis from Japan (present in $\mathrm{R} . \mathrm{II}{ }^{1}$ ) but differ from it in more distant furrows. The species is distributed from Suez to N. Caledonia (LAмy 1907).

A. imbricata BRUGuière, var. avellana LAMARCK (= Byssoarca maculala Sow ERBr, ReEve Conch. Icon. 2, Pl. XI, fig. 71, according to LAmY 1907). 45 miles W. S. W., 60 feet $(2 / 7), 1$ sp., covered with spongiae, 1. $29 \mathrm{~mm}$. - For the distribution (Indian Ocean to Japan) and synonyms see LyNGE 1909.

A. complanata Chemnitz. 42 miles W. S. W., 70 feet $\left({ }^{30} / 5\right), 1 \mathrm{sp} ., 1.41 \mathrm{~mm}$; 45 miles W. S. W., 66 feet $(29 / 5), 2 \mathrm{sps}, 1.50 \mathrm{~mm} ; 48$ feet $(8 / r), 2 \mathrm{sps}, \max , 1.27 \mathrm{~mm}$. The sculpture of these specimens most closely approaches that of the form Arca velata SowERnY, but the position of the umbones resembles that of specimens of $A$. decussata, from Eimeo for example (R. M.). The present form differs from both in having a wing in the posterio-superior corner; in this characteristic it agrees with the figure of $A$. decussala given by REEvE (Conch. Icon. 2, 1S44, Pl. XII, fig. 8I). LYNGE (1909) comprises both $A$. veluta and A. decussalu in A. complanata. 'The species has a wide distribution from the Red Sea to Japan, New '/ealand, Society and Galapagos Islands (LFNGE 1909).

A. plicata Cuemritz (= divaricata Sowerbi). 45 miles W.S. IV., $66-70$ feet. $\left({ }^{15} / 7\right), 2$ sps., max. 1. $18 \mathrm{~mm}$. The sculpture completely agrees with figs. $10 \mathrm{~s}$ and 112 in ReEve (Conch. Icon. 2, 1884), but the shape is variable; the large specimen

' Swedish State Museum of Natural Ilistory ("Riksmusemm»). 
has its anterior part somewhat produced towards the front and above; the smaller one is more like fig. 108 but with a more obvionsly indicated angle between the hinder and the upper margins. - LYvGE (1909) includes this form, which has a wide distribution in the Indian Ocean, with the American gradata and squamosa, and some others.

Pectunculus holosericus ReEve. 45 miles IV. S. IV., 66 feet $(2 \%), 1$ sp., 1. $38 \mathrm{~mm}$. The species is easily recognized from the figure and description given by Riseve (fig. 18. Conch. Icon. 1, 1843). It is previously recorded from New South Wales (E. A. SMiti 1885).

P. vitreus IsAMARCK (Pl. 1, figs. 12, 13). 45 miles W. S. W., 48 feet $(8 / 8), 1$ sp., 1. $20 \mathrm{~mm} ; 42$ miles $\mathrm{IV}$. S. W., 72 feet $\left({ }^{14} / 8\right), 1$ sp., $1.22 .5 \mathrm{~mm}$. REeve's fig. 44 (Conch. Icon. 1, 1843) seems to present an older specimen; the present specimens have dark brownish spots and somewhat broader ribs than the figured one, but in other parts they are very like it. MeLvill \& STANDEN report the species from Torres Strait (1899). The distribution is otherwise unknown (cf. LaMr 1911).

In the animal there are to be observed a series of large calcareous concretions situated within the nephridia (but seemingly confined to the intestine). Such secretions are also observed by PeLseneer in P. aurifluus (1911).

The present specimens correspond in their somewhat sloping and less convex anterior and posterior margins better to $P$. vitreus than to the rather similar $P$. orhicularis Angas (Proc. Zool. Soc. 1879, pl. XXXV, fig. 9), which has a more orbicular outline.

P. setiger n. sp. (Pl. 1, figs. 14, 15). Shell rounded oblong, with inflated umbones, upper margin nearly straight, outline for the rest well rounded. Sculpture consisting of about 35 coarse radiating ribs, transversally divided into tubercles, the interstices as broad as the ribs, or broader towards the margins, and bearing 2-3 radiating rows of cuticular hairs, which are longer towards the anterior margin. Colour brownish, marbled with white, forming 2-4 concentric bands on the lower and median part of the valves, and large confluent dots towards the umbones; ligamental area brown-striped, white-bordered. Dimensions: 1. 19, h. 18, thickness $12 \mathrm{~mm}$. Locality: 48 miles W. S. W., 78 feet $\left({ }^{15} / 7\right), 1$ sp. This species closely resembles in colour and sculpture $P$. cardiformis Angas (Proc. Zool. Soc. 1879, pl. XXXV, fig. 6), but differs from it in its dorsal margin and the broader interstices between the ribs, as well as in its cuticular hairs.

Limopsis multistriata ForskiL. 48 miles W. S. W., 78 feet, 1 sp., 1. 19 mm; 45 miles W. S. W., 48 feet $\left({ }^{8} / 7\right), 2$ sps, max. 1. $20 \mathrm{~mm}$. The specimens collected agree completely with specimens of this species from the Red Sea (in R. M.). Recorded, further, from the Arabian Sea, Singapore, Gulf of Siam, Japan, 'Torres Strait and Port Jackson (LYNGE 1909). 


\section{FAM. TRIGONIIDAE.}

Trigonia (Neotrigonia) uniophora GraY (Pl. 1, fig. 16). ${ }^{3} 45$ miles W. S. W., 48 feet $(8 / 7), 1$ sp., 1. $20 \mathrm{~mm} ; 60$ feet $\left({ }^{13} / 7\right), 1$ right valve on a sponge, $1.5 \mathrm{~mm} ; 4 \mathrm{~S}$ miles W. S. W., 78 feet $\left({ }^{15} / 7\right), 1$ sp., l. $21 \mathrm{~mm}$; 42 miles W. S. W., 72 feet $\left({ }^{14} / 7\right)$, 2 sps, max. l. $20 \mathrm{~mm}$. All the specimens agree with some shells sent by Mr. Hedery, as well as with figure $2 a$ in ReEve (Conch. Icon. 12, 1860). This species was previously known only from Torres Strait and south of N. Guinea, 3-28 fms (E.A. SMiti 1885). Mr. HedeEy informs me that is has, besides, been recorded from Indian Island, Bynoe Harbour, W. A., and Port Darwin, N. Terr., by BednalL (Trans. Philos. Soc. Adelaide I, 1878, p. 80).

T. uniophora GraY, var. crebrisculpta n. var. (Pl. 1, fig. 17). This variety differs from the typical form in sculpture and colour. The former consists of in all 28 radiating ribs, of which there are 19 in the anterior part (as far back as to the hinder angularity), in the furrow above it 1, and on the wing 4 ribs; above the last-named, there are 4 rows of isolated tubercles. On the upper parts of the ribs the tubercles are close-set and transversally dilated, on the under half of the shell, they are more distant and rounded, with smaller interstices in the same rib than the diameter of the tubercles. The interstices between the ribs are equal to the ribs in breadth. The colour is very light yellowish red. Locality: 45 miles W. S. W., 140 feet $\left({ }^{12} / 7\right), 1$ sp., l. 13, h. 12.3 , breadth $7.4 \mathrm{~mm}$.

A comparison with $T$. uniophora (type) as to the sculpture, shows that there is a considerable difference in the number of ribs in the present form and in the typical specimens collected at Cape Jaubert. In the last-named there are 16 (one specimen 15) anterior ribs, 2 (1) ribs in the furrow, 3 (4) on the wing and 2 or 3 (exceptionally 4) rows of tubercles above them.

In shape the present form is quite like the type. It seems to be a variety thereof, as the difference does not seem to be so great that a specific distinction is well founded. Its larger and stronger tubercles place it in about the same ratio to T. uniophora, as is for example T. margaritacea var. bednalli Verco (1907) to its head form. This last-named variety is characterized by its very compressed shape, its narrow ribs, its large, oblong, plate-like spines, broader at their free than at their attached ends, features which are exceedingly constant in the very large series obtaineds. In the present new variety the tubercles are swollen, not flattened. The new variety most resembles fig. $2 b$ of $T$. uniphora in REeve (Conch. Icon. 12, 1860). From T. strangei A. ADAMs, of which two valves were kindley sent to me by Mr. HEDLEY, the new variety differs in having more rounded not transversally dilated knobs, as well as in the presence of a sinus in the posterior margin.

\footnotetext{
'For the name Neotrigonia see Cossmasx, Anu. de P'aléoutologic, tome VII, fasc. II, 1912.
} 


\section{FAM.CARDITIDAE.}

Cardita crassicostata Lamarck. 45 miles IV. S. WV., $60-72$ feet $\left({ }^{11-23 / 3}\right), 4$ sps, max. l. $65 \mathrm{~mm}$, the large sp. with densely set, the smaller with more separated squamulae (the former thus similar to ReEve's fig. $7 d$ and the latter to $7 a$, Conch. Icon. 1, 1843); 42 miles W. S. W., 70 feet $\left({ }^{24} / 8\right), 2$ sps, max. 1. $48 \mathrm{~mm}$. - Philippines (Reeve); N. W. Australia (Brazier 1885); Queensland (Hedetey 1910), Victoria (Pritchard \& Gatliff 1904); S. Australia (Verco 1908); IV. Australia (Hediey 1916).

C. incrassata Sowerby (incl. C. mamorata ReEve), 45 miles W. S. W., 48 feet $(8 / 2), 4$ sps, and 72 feet $\left({ }^{16} / 7\right), 1$ sp. The large specimens (max. $1.41 \mathrm{~mm}$ ) from 48 feet have a lengthened shape, reminding one strongly of C' marmorata (REEvE's fig. 12), while the smaller ones are comparatively more elevated and shorter (= REEve's fig. $11 b=C$. mbicunda IIENKE); they are light reddish with brown dots as in the typical $C$. marmorata, but no unicoloured dots as in REEvE's fig. 11 a occur. - 42 miles IV. S. W., 42 feet $\left({ }^{10} / 7\right), 2$ sps, max. 1. $32 \mathrm{~mm}$. - ReEve gives this species from New Holland, and HEDLEY (1910) records it from Queensland, and (1916) W. Australia.

C. squamigera Desinyes (Pl. I, figs. 18, 19). 45 miles $W$. S. W., 48 feet $(8 / 7)$, I sp., l. $27 \mathrm{~mm} ; 60$ feet $\left({ }^{13} / \mathrm{r}\right)$, 1 right valve, 1. $15.5 \mathrm{~mm}$. ReEve (Conch. Icon. 1, fig. 14) mentions 18 ribs and a yellowish brown colour, while in the present specimens the number of ribs is 22 , and the colour is white with brown dots, as in C. variegata Brugunere. The ribs are, however, elevated and equal in breadth to the deep interjacent furrows and covered with distant raised squamulae in the median ones and transversal tubercles on the anterior, while, posteriorly, the lines of growth are prominent as fine folds. Any other species than $C$. squamigera seems me to be out of the question for identification, the more so as the figure given by CLessin in Conch. Cab. 10:1, 1888, is more like the present species than that of REEVE (fig. 14). The locality of the original specimen is unknown. CLessin gives Australia as its habitat.

\section{FAM. LUCINIDAE.}

Phacoides rugosus Hedier (= Lucina seminula Goumo). 45 miles W. S. W., 66 feet $(29 / \mathrm{s}), 3$ valves, max. $1.3 .5 \mathrm{~mm}$, which agree completely with the excellent figure given by HEDLeY (1909, pl. 37, fig. 17). - Distribution: S. Guinea; Hongkong (SMiti 1885); 'Torres Straits (HedLeY 1909); Gulf of Siam (LrNGE 1909).

FAM. ERYCINIDAR.

Kellya cycladiformis Desinyes. 42 miles W.S. W., 70 feet $\left({ }^{25} / 5\right), 1$ sh., l. S mm. - Distribution: Gulf of Siam, Queensland to Vietoria, New Zealand (LrNaE 1909). 


\section{FAM. GALEOMMATIDAR.}

Ephippodonta granulifera 11. sp. (PI. 1, fig. 20, text figs. 3, 4). Mussle with the valves widely gaping, elliptic in outline seen from above, its breadth being more than half its length. Valves elongated ovate, convex, with the dorsal margin straight, anterior and posterior margins rather abruptly set off from the dorsal margin, and forming a rounded corner with the inferior margin, the latter only feebly convex. Umbones somewhat in front of the middle. Median part of the shell strongly inflated, towards each end passing into a strong depression. Sculpture (fig. 4) consists of extremely fine and dense radiating dichotomically branching costae, set with very minute and dense granulae in a concentric arrangement all over the valve. Colour

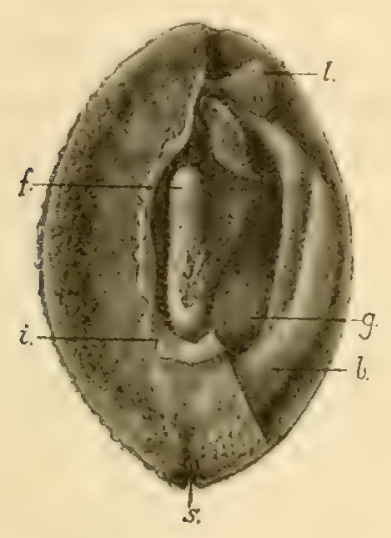

Fig. 3. Ephippodonta granulifera n. sp. Animal from under side; left valvo and mantle half removed. b. gills, fo foot with byssus; $g$. genital organs, $i$. inner brim of mantle; l. Iabinl palps; 8. branchial sipho.

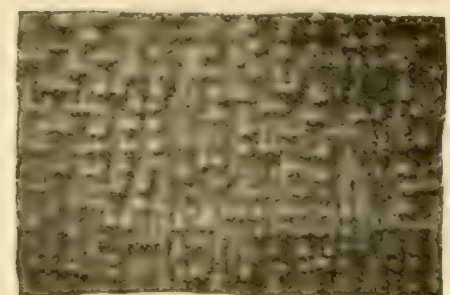

Fig. 4. Sholl sculpture of Ephippodonta granuli/era n. sp. $\times \mathbf{4 0 .}$

snowy. Dimensions of the valves: 1. 11.6; h. 5.4; breadth of the mussle $7 \mathrm{~mm}$. Mantle minutely papillated exteriorly and covering the valves, except for a narrow median stripe across each valve.

Inferior side of the mussle (fig. 3) shows a wide and thickened expansion of the mantle, filling the gap between the valves, but leaving for the foot a median split, which stretches from the second third to the hinder end; mantle edges with a densely tentaculated brim. Locality: 45 miles $W . S . W ., 72$ feet $(1 / 2), 1$ sp.

This new and interesting form differs from E. macdougalli established by TATE (1889) and later on described in greater detail by WoODWARD (1893), in its granular surface and the imperfect reflection of the mantle over the shell. The nearly equalsized E. macdougalli, max. $11 \mathrm{~mm}$ (WOODWARD) has spiny valves, which are entirely covered by the mantle. 
FAM.TELLINIDAE.

Tellina rhomboides Quox \& Gamand. 45 miles W. S. IV., 72 feet $(2 / 7), 1$ sp., 1. $9 \mathrm{~mm}$, with 2 red rays behind. - Distribution: From the Red Sea and Mauritius to the Philippines, Japan, New Guinea, Queensland, and New Zealand (Lrxas 1909).

FAM. MYIDAE.

Corbula crassa Hivds, 45 miles IV. S. W., 60-72 feet $\left({ }^{8-1 / 7 / 7}\right), 3$ small dead shells, max. I. $7 \mathrm{~mm}$; 140 feet $\left({ }^{12} / 7\right)$, I sp., $1.17 \mathrm{~mm}$. - Distribution: Gulf of Manaar to Gulf to Siam and Philippines; New Guinea, Queensland, N. W. Australia (LYNGE 1909).

\section{FAM. VENERIDAE.}

Venerupis irus Tinné (= macrophylla Drsirayes). 45 miles W. S. W., 72 feet $\left({ }^{0-13 / 3}\right), 4$ sps, max. l. $8 \mathrm{~mm} ; 42$ miles $W$. S. W., 70 feet $\left({ }^{20} / \mathrm{s}\right), 3 \mathrm{sps}, \max .1 .10 .2$ mm. It is distributed from England and Ireland through the Mediterranean and Red Seas to the Gulf of Siam, Philippines and Japan, as well as from Funafuti to Nauritius (LXNGE 1909).

For the synonyms of this species see LYNGE 1909.

Paphia sulcaria IıAMArck. 42 miles W. S. W., $66-70$ feet $\left({ }^{11 / 7}\right), 2$ sps, max. 1. $11.8 \mathrm{~mm}$. - Distribution: Red Sea-Noluccas, Indian Ocean (E. A. Surti 1891).

Chione foliacea Pindrpi (= tiara Rerve). 45 miles W. S. W., 48 feet $(5 / \%)$, 2 sps, max. 1. $13 \mathrm{~mm} ; 66$ feet $\left({ }^{15} / 7\right), 2$ sps, $\max .1 .18 \mathrm{~mm} ; 140$ feet $\left({ }^{12} / 7\right), 1 \mathrm{sp} ., 1$. $19 \mathrm{~mm} ; 48$ miles W. S. W., 78 feet $\left({ }^{15} / 7\right), 2$ sps, max. 1. $9 \mathrm{~mm}$. - Distribution: Red Sea, Madagascar, Ceylon, Queensland, Japan (E. A. SMiti 1885).

Ch. recognita E. A. Snutif. 45 miles IV. S. W., 66 feet $\left({ }^{15} / 7\right), 1$ sp., 1. $8.8 \mathrm{~mm}$, agreeing both in form and sculpture with Surti's fig. 5 (Pl. III, Challenger Rep. Lamellibranchia, 1885). The specimen was light reddish, with 2 brown dots on both valves, placed behind each other and on the upper half, thus causing a striking resemblance to the new Trivia bipunclala collected in the same locality. - Distribution: Maldives, Gulf of Siam, Philippines, Queensland (Lxage 1909).

Ch. laticostata n. sp. (Pl. 1, figs. 21, 22). 45 miles W. S. W., 70 feet $\left({ }^{1} / 6\right)$, $1 \mathrm{sp}$, , 1. $20 \mathrm{~mm}$, br. 11.5, h. $14 \mathrm{~mm}$. Shell elongated ovate, somewhat contracted towards the rear end, with submedian umbones, sculptured with about 15 concentric costae with narrow interstices, the last three of them very broad, occupying half the under part of the shell. 'Towards the hinder end the costae form indistinct and somewhat thickened angles. The costae are crossed by fine and dense radiating threads and microscopic striae, the former most risible in the interstices and towards the front margin, where they form coarse crenelations; smaller ones are present in the under and the posterior margins. Shell crean coloured with three cloudy light brown 
rays or flames; area extended and narrow with some transversal brown spots. Inside white with a light rosy tint in the median part. Isunula narrow, bounded by a deep furrow.

The shape of this shell recalls a Macrocallista or a T'apes, but the coarse sculpture is that of a Chione, except for the fact that it has only feebly indicated posterior prominences or lappets on the costae.

Circe plana n. sp. (Pl. 1, figs. 23-25). Shell somewhat squarely rounded in outline, highly compressed, sculptured with coarse concentric ridges towards the under margin; umbonal part smooth, diagonally slightly wrinkled at the sides; colour pale yellowish with two diverging rays of brown dots on the upper half and angular brown stripes on the lower half of the shell, the colouration being more obvious on its inside. Dimensions: 1. 31, h. 29, thickness (valves closed) $4.6 \mathrm{~mm}$. Locality: 45 miles W. S. W., 48 feet $\left({ }^{8}, 7\right), 1 \mathrm{sp}$.

The difference between this form and $C$. scripta Linsé, of which it is perhaps only a variety, lies chiefly in its considerable compression from the sides, and the fewer, but coarser, concentric costae, which number about 20 in all. A typical $C$. scripta of about the same size has these proportions; 1. 35.5, h. 29.5 thickness $9.5 \mathrm{~mm}$, and its finer and denser concentric ribs are about 32 in number. As to the interior, it is remarkable that in $C$. plana both the anterior side teeth of the right valve run in the prolongation of the foremost cardinal, while in $C$. scripla they form together a slight curve. Even in the soft parts there seem to exist differences, as in $C$. plana the posterior adductor has a length $=3$ times its breadth, and the posterior gill is about $1 / 4$ of the anterior one in breadth, while in $C$. scripta the posterior adductor has a length of scarcely twice its breadth, and the posterior gill is about $1 / 3$ of the anterjor one in breadth.

\section{FAM. PETRICOLIDAW.}

Naranio lapicida Chennitz. 42 miles IV. S. W., 66 feet (11/8), 1 sp., 1. $7.4 \mathrm{~mm}$. Distribution: Persian Gulf, Red Sea, Mauritius; Gulf of Siam to Queensland-S. Australia; Florida and Lesser Antilles (Ly YaE 1909).

\section{FAH. CARDIIDAE}

Cardium (Trachycardium) foveolatum SowsRBY. 45 miles IV. S. W., 66 feet $\left({ }^{15} / \mathrm{r}\right), 1 \mathrm{sp}, 1.10 \mathrm{~mm}$. The specimen agrees with the figure in Römer $(1869$, MARTINI \& Cremsitz, Conch. Cab. Pl. 11, fig. 8) and his description (p. 65) better than with fig. 87 in REEvE (Conch. Icon. 2, 1844), where the shape is more produced than in the present specimen. REEVE records the species from Swan River.

C. (Laevicardium) lyratum SowerbY, 45 miles W. S. WV., 66 feet $\left({ }^{15 / 8}\right) 1$ sp., 1. $6 \mathrm{~mm}$. Though of small size the present specimen shows distinctly the character- 
istic oblique rugations on the anterior part of the shell. - Distribution: E. Africa; Seychelles (v. MLartens 1880); Philippines (Rfeve); Queensland (Hedele 1910).

C. (Laevicardium) biradiatum Brugurère. 42 miles W. S. W., 70 feet $\left({ }^{29} / 5\right)$, $1 \mathrm{sp} .$, 1. $26 \mathrm{~mm}$, like fig. 49 in ReEve 1844. Distribution: Seychelles (v. Martexs 1850); Maldives and Laceadives (E. A. Sintri 1903); Ceylon, Andaman I., Amirantes, Seychelles (Melvill 1909); Philippines (Rewri); Queensland (HedLey 1910).

C. (Papyridea) papyraceum Cinmnitz. 48 miles W. S. W., 78 feet $\left({ }^{15} / 8\right), 2 \mathrm{sps}$, 1. 19 and $11 \mathrm{~mm}$. - Distribution from the Persian Gulf and Suez to Natal, Philippines and Japan; N. and E. Australia (LYNGE 1909).

\section{FAM.CHAMIDAE}

Chama lazarus Linné. 45 miles W. S. W., 60-66 feet $\left({ }^{29} / 5\right), 2$ sps and 2 valves, max. h. (sp.) $43 \mathrm{~mm}$. This species is one of the most characteristic of the genus and is well reproduced by RELve (Conch. Icon. 4, 1846, Pl. II, fig. 4). Its colour is white, with $2-3$ reddish brown rays on the posterior half of the shell, and a lemon yellow tint on the umbones; the inner side is uniformly white, finely grained, and striped radially. Characteristic are, further, the broad erect, somewhat undulating or foliaceous lamellae which extend over the whole shell and in the umbones are simple and even, not undulating or subspinulose, as in most of the Chamidae; the posterior muscular impression is lengthened ovate and does not reach the base of the hinge plate; the smooth marginal zone of the valves (out of the mantle line) is rather broad, about half as broad as the muscle scars.

To this species I refer Chama pulchella REEvE (Conch. Icon. 4, 1846, fig. 10 a), a species in which REEve comprised not only dextral but also sinistral shells. He figures in fig. $10 b$ a specimen with the umbones turned from right to left, which, in its exterior appearance (colour and sculpture) is strikingly similar to the dextral fig. $10 a$. Nevertheless, the specimen $10 b$ must be distinguished from that of fig. $10 a$ and referred not only to a distinct species but also to a new genus, Pseudochama, comprising the sinistral Chamas and characterized by differences in dentition and anatomy (see below). Through the kindness of Mr. S. F. HARMer, I got an opportunity of comparing photographs of the two forms in question from the inside, and they show the most apparent agreement with the typical conditions in either genus. Ch. pulchella of REEve consequently must be restricted to the dextral specimen of fig. $10 \mathrm{a}$, and for that of $10 \mathrm{~b}$ I propose the new specific name Pseudochama similis.

Even in the most recent manuals and other publications dealing with the Chamidae, one meets with the statement that in Chama the umbones are turned to the right or to the left indifferently even in the same specimen $;^{1}$ but no other example of this condition is said to be known than the above named Ch. pulchella (in REEvE's

1 Only ANTHONy (1905) remarks that ne has never found both conditions prevailing within one and the 
sense), which is repeated also by PeLseneEr (1911) in these words (p. 58): sLes espèces de ce genre ne sont pas toutes fixées sur le côté gauche: il existe des formes sinverses», fixées par le côté droit... (dans C. pulchella REEv£ d'Australie, la fixation se ferait indifféremment sur l'un ou l'autre côté).?

Through my own researches on Chama, which will be published later on, this view is shown to be quite unmaintainable and a subdivision of Chama as hitherto understood into Chama and Pseudochama corresponding to the normals and sinverses Chamas has for this reason been made (see further below).

Ch. spinosa Broderip. 45 miles W. S. W., 1 sp., 1. $20 \mathrm{~mm}$, with soft parts preserved and a specimen of Pinnotheres within the shell. 'The specimen, which agrees in shape and sculpture with fig. $44 b$ of REEve (Conch. Icon 4), was entirely overgrown with bryozoa but still exhibited the characteristic convexity and solidity of the shell, the minutely spinous sculpture, as well as, interiorly, the smooth or very faintly crenelated margins, the greenish gray tint and somewhat greasy lustre, as well as the solidity of the posterior tooth $(3 b)$, which is separated from the very indistinct, nearly suppressed anterior one $(3 a)$ by an intermittent depression, while in $C h$. reflexa both teeth are joined like a crest, which rises from the hinge plate and is distinctly separated by a furrow from the upper shell margin. E. A. Sintrin (1885) records this species from Port Jackson, and ReEve from Iord Hood's Island. In R. M. there exist examples from the Red Sea, Madagascar and Taliti.

Ch. reflexa Rerve. 42 miles W. S. W., 70-72 feet $\left({ }^{25} / 5\right)$, many sps, max. I. $48 \mathrm{~mm} ; 45$ miles W. S. W., 60-80 feet ( $\left.{ }^{29} / 6\right)$, many sps, max, h. $70 \mathrm{~mm}$. 'T'o this species I refer $C h$. jukesi REEVE, which proves to be merely the not full-grown (though mature) stages of $C h$. reflexa. The ample material before me shows the complete transition from the smaller forms with dense and fine spines and without the two rows of squamulae on the hinder side of the shell, which constitute the form jukesi, to larger specimens where the spines are more expanded and where there are two rows of radiating squamulae posteriorly. Also in colour may be observed this transition from the pale younger specimens (forma jukesi) to the more or less deeply reddish adult ones (the typical $C h$. reflexa).

The largest of the present specimens is marbled with red and yellow, and the inside of the inferior valve is violet. 'Iwo somewhat smaller specimens (max, h. 50 $\mathrm{mm}$ ) have retained the white colour of forma juliesi, in addition to a rosy tint on the umbones; the under valves are inwardly flesh-coloured in the larger, white in the smaller specimen. In its sculpture, consisting of dense squamulae, the larger of the named shells approaches Ch. mullisquamosa ReEve (Conch. Icon. 4, fig. 12), which may perhaps be a variety of the present species. 'The deeper the shell is coloured, tho stronger the animal is pigmented around and between the siphonal openings.

There is the closest similarity between the present specimens and some shells from Java and from the Red Sea in the collections of the Swedish State Museum. The last-named form part of the collections made by M'ANDREw in 1856 and differ only in the great solidity of their valves. 'Their exterior is usually much 
disturbed by boring organisms and overgrown with lime crusts, for which reason the shells get a porous structure, a feature that has led Cusssin to establish (very unhappily, as this is a far from essential characteristic) for this form a new species Ch. porosa. As to the synonyms of the species, it must be remarked that Cooke (1886) is incorrect in identifying the sinistral Ch. cornucopia REEVE with the present species; however striking their outer resemblance may be, they belong to different genera, the last-named species belonging to P'seudochama.

The characterization of this species given by REEve (Conch. Icon. 4, 1847) is not adequate, as it considers merely unessential characteristics, such as a reflection of the margin of the lower valve. It is very difficult to indicate the real peculiarities of the species as concerns the shell. The shell sculpture and colour vary considerably, sometimes the concentric lamellation is obvious, sometimes it is quite obscure and dominated by the development of the more or less depressed scales or spines. 'To the same species also certainly belong many other of REEvE's species», such as Ch. aspersa, planala, obliquata, muea, and sulphurea. ${ }^{1}$ Ch. reflexa differs from the West Indian $C h$. eclinata (in which probably are to be included $C h$. sordida BRoderil and sarda REEVP, perhaps also Ch. venosa ReEve, in that it lacks the divaricate sculpture of the last-named form expressed in the direction towards the posterior of the radiating lines and stripes along the hinder shell margin.

Good distinctions between the different species of the Chamidac are also to be observed from the anatomy, as will be found from the accounts below.

Pseudochama cristella (IAMARcK) [=Chama reereana Cutissin]. 42 miles W. S. $11 ., 70-72$ feet $(25 / 5)$, about 6 sps, max. 1. $31 \mathrm{~mm}$. - LYNGE (1908) gives a satisfactory criticism of CreSSIN's opinion as to the Chama cristclla of REEVE, which, according to the last-named author, is specifically distinct from the type of LAMARCK, a view that cannot be maintained. The species is distributed from the Gulf of Siam to Java, the Moluccas, and Australia (LYNGE 1909). It is at once recognized by its orange colour and raised crista-shaped form, due to its attachment with the front half of the right valve, while its hind part is sharply bent from the substratum. I have referred this species to a new genus, Pseudochama, which comprises the so-called inverse» Cluamas, opposite to the normal or dextrally twisted ones, to which the old name is to be restricted. A complete discussion of this opinion and the reasons for establishing the new genus will be published in a special paper; here I only give a summary of the distinguishing points and the characteristics of the new genus. The dentition of these inverse or ssinistral» Chamas is developed in a quite different manner from that of Chama sensu stricto; the final result becomes a feature that is somewhat like the mirror image of the dentition of a Chama, so that the attached valves, in the former case the right, in the latter the left one, grow symmetric to each other, which has given rise to a misinterpretation of the conditions prevailing, known as the theory of the symmetric valves, and to a new Ch. julicsi.

1\%. A. Surn (1885) considers Ch. fibule and $C h$. pellis phocae both of ReEve, to be identical wilh 
denomination (by Munrer-Chatras) in opposition to the rule of homology. This comprehension of the genus Pseudochama as representing a phenomenon of inversion of the Chama type has been uncritically accepted by all the malacologists writing on the subject, and has hitherto rested unrefuted.

After a close investigation of many forms of Chamas, consiclering their ontogeny as well as the conchological and the anatomical conditions, I was convinced that a division into the two genera Chama and Pseudochama (comprising also Echinochama) is necessary. The distinguishing characteristics are the following: The dentition in Chama may be expressed (in accordance with BERNARD, 1895) thus:

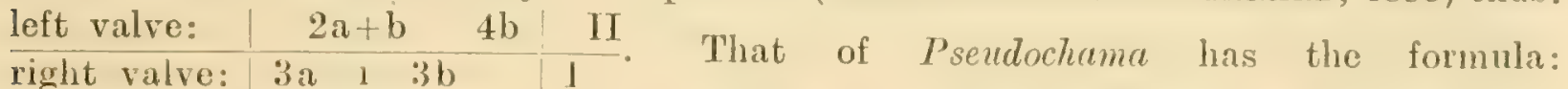
\begin{tabular}{l|c|c|c|} 
left valve: $\mid 2 a 2 b 4 b$ & II \\
\hline right valve: & $13 b$
\end{tabular} \mid The difference is more obvious in young than in older shells. The nepionic shell in Chama is very small (about $0.5 \mathrm{~mm}$ ) and has a minute sculpture of close radiating and somewhat more distant concentric riblets (cf. ANTHONy 1905). In Pseudochama the nepionic shell is sculptured just as in Echinochama with rather remote concentric lamellae, and no or only traces of radiating riblets; further its size is more considerable $(1.4-2.5 \mathrm{~mm})$. There are also some points of difference in the anatomical characteristics, inasmuch as Chama has a stomachal coecum directed forewards, which is wanting in Psendochama, and the nephridia of the former genus have the pericardial tubes wholly embedded in the external sacs, while in P'seudochama they are left uncovered on their median side.

\section{Survey of the Anatomy of Chamidae.}

The following accounts are based on an examination of the forms present in the collections from N. W. Australia and are an extract from a more exhaustive inquiry on the family, which will be published later on. As they are of importance for the comprehension of affinities in the group of Lamellibranchia and have a special interest in the matter of a comparison with Chamostrea described later, they are included in this publication.

The gills and the blood system. When the respiratory organs of the forms of Lamellibranchia have been studied, the examination has always been limited to the detailed anatomy and the histology. But such an investigation does not lead to an exact comprehension of the organization of the branchial apparatus as a whole. Its function is full-filled in the service of the circulatory system, and therefore we have to study it as an organ intimately connected with the blood system, a point of view which has been too much neglected. The accounts accessible in the literature on the subject give very little and seemingly contradictory information about the gills as blood-carrying organs. I therefore made it my task, by studying the Chemidae, to get an idea of the whole blood circuit within the gill. This was possible by following, on sections, the blood vessels back to the larger trunks from where they' 
emanate. The circulation within the gill of Chamidae, which is of the folded synaptorhabdic type, was then found to be as follows.

The venous blood is carried out from two different sources into the gills, partly from the renal sinus and partly from the anterior blood lacunae in the visceral hump. From the renal sinus an afferent axial trunk passes into the branchial axis and runs down its whole length. It gives off laterals to the posterior gill only, and each lateral is enclosed in a principal filamentar septum; further, we note the fact that each second septum contains an afferent vessel and each interjacent one an efferent. The blood from the afferent vessels is distributed through the interfilamentar junctions, and the filaments into those sides of a fold of the gill which incline towards a renous septum; the opposite fold sides again collect the blood that has been arterialized within the fold and carry it towards the efferent principal vessel. From here the blood is led by the arterial trunk into the gill axis, which debouches into the atrium of the heart.

The afferent principal vessels of the posterior gill are distally joined to a marginal vein enclosed into the upper margin of the reflected gill lamella. This also emanates from the renal sinus. The efferent ressels, on the contrary, have no corresponding distal connection, but taper and terminate towards the margin of the lamella.

In the anterior demi-branch the conditions are somewhat different. All the afferent vessels here emanate from the upper margin of the reflected lamella, which encloses a vein, which is a continuation of the vena cava, which receives all the blood from the intravisceral lacunae and carries it backwards. The vena cava begins in the neighbourhood of the mouth, where an anterior vessel (from the adductor and the mantle), an inferior (from the foot), and a superior (from the umbones), join. - From the marginal vein of the anterior demi-branch, the afferent principal vessels plunge down, also here confined to each second principal filament. In this demi-branch the principal filaments of opposite lamellae join to interlamellar septa, which then contain the blood vessels, these being also here, as named, alternately afferent and efferent. It is a remarkable fact that the afferent septa stretch higher up towards the gill axis than do the interjacent efferent ones, so that thus the septa also alternate in length.

The arterialization of the blood takes place into the same way as in the posterior demi-branch, in alternating synclinal folds, and the efferent septal vessels, which begin step by step under the free margin of the reflected lamellae and are not combined by any marginal vessel, debouch into the axial efferent trunk that carries the blood directly into the auricle.

A comparison with the conditions prevaling in other Lamellibranchia would be beyond the limits of the present publication; only so much may be stated, that there are essential differences in the infra-branchial blood circuit as regards the different types of branchiae.

Also the extra-branchial or infra-visceral portion of the circulatory system in Chamidac presents some peculiarities not before known. From the anterior aorta 
there branches off, immediately after its outset from the heart, an arteria gastrica, which descends on the left body side, similarly in Chama and Pseudochama, to the left of the intestine, towards the stomach; here it bifurcates and descends with one arm on each side of the duodenum. The principal trunk of the anterior aorta passes on above the stomach (in I'seudochama cristella to the left of it) and along the left side of the oesophagus (similarly in Chama and Pseudochama), from where it gives off a branch to the anterior adductor and one into the foot. - The posterior aorta presents nothing of interest; it sends a ventral trunk downwards between the nephridia and the posterior addnctor and one along the under side of the rectum towards the siphons. - As to the veins, it has already been described how they are arranged. It remains only to say that a special pallial vein carries the blood from the mantle directly into the auricle.

The intestinal canal. The stomach, which follows behind the simple oesophagus, presents in all the present forms great resemblances, but there are differences as to the coecal appendages and the liver ducts. Pseudochama cristella has a very small coecum on the posterior side of the stomach, while in both the Chamas this attains more considerable size. Further, in $P$. crislella no lateral coecum of the stomach is present (the absence of this is characteristic of the whole genus Psendochama, cf. above), this feature being confined to the genus Chama. Between the two species $C h$. lazams and $C h$. reflexa there exists the difference that in the lastnamed we find, as the rule, a single principal liver duct (so even in Pseudochama cristella), while $C h$. luzarus has two. For the rest, nothing of interest is to be noted. In all the three present forms the duodenum has a narrow furrow to the left and a larger one (corresponding to the crystalline coecum) to the right; ${ }^{1}$ in its lower end the duodenum passes into the intestine through a simple flexure, and this, later on, pierces the ventricle and leads to the anus.

The liver surrounds the stomach not only on its frontal and lateral, but also on its posterior and superior sides.

The nervous system. Grieser has described the organization of this system for $C h$. pellucida and the same conditions that he has found prevail in all Chamidae (Chama as well as Pseudochama). A distinct buccal ganglion is present beneath each cerebral centre, by a suboesophageal commissure combined with that of the other side. There is also a median commissure between the cerebrovisceral connectives in front of the pericard, established between the genital nerves, which here emanate from the nerve cords.

As to the genital organs, all Chamidae are gonochoristic; the folliculi fill all the visceral hump outside the liver and intestinal canal; the genital pores have somewhat projecting and muscular lips.

The nephridia were briefly described by me in 1912. They are situated behind the pericard and in front of the posterior adductor, and extend in a dorso-ventral direction up to the sides of the rectum; the left one is highest in Chama,

1 Similarly in Chama and Psculochuma; Griesen (1913) states for C\%. pellucila the reversed position. li. s.. Vet. Akml. Handl, Baml 52. Ni:0 16. 
the right one in Pseudochama. The pericardial tubes emanate through long and narrow oscular ciliated funnels from the lateral corners of the pericard. The sequent portion of them is widened and furnished with folded walls; then the tubes narrow again and extend, either surrounded by the outer sacs (Chama) or uncovered by them on their median side (Pseudochama), upward till they debouch into the outer sacs, earlier in Chama than in Pseudochama. 'The Iobation of the external sacs is minute and the lining cells are larger (bladder-like) in Chama than in Pseudochama. The nephridia open out somewhat below the genital organs, distinctly separated and opposite to the genital pores.

II uscles. As a consequence of the reduction of the foot, all Chamidae have the foot retractors vestigial, but they still retain different degrees of development in the different species, thus in Ch. lazarus the retractors are much more conspicuous than in Ch. reflexa and Pseudochama cristella and reach the shell, where they are inserted, which they are not in the last-named forms.

\section{FAM. SAXICAVIDAE.}

Saxicava arctica Linné (rar. australis LAMARCK). 45 miles W. S. W., 70 feet $(1 / \mathrm{s}), 1$ sp:, 1. It mm. 'ThTE and MAY (1901) consider LAMARCi's S. australis, to which the present specimen belongs, as identical with $S$. arctica and S. pholadis LıNné.

\section{HAH. CHAMOSTREIDAE}

Chamostrea plicifera n. sp. (Pl. 1, figs. 26-32, text figs. 5, 6). Shell sessile, its right valve being attached by means of its anterior half, and the posterior half of it being raised from the underground; its shape triangularly ovate, and its colour light yellowish green, with three dark olive brown lines running from the umbones to the posterior margin of the upper as well as of the lower valve. Upper valve operculiform, its superior margin lighly arcuated, the posterior margin a little longer and less curved, separated at an angle from the short inferior side; anterior margin stretching perpendicularly up to the umbo and separated from it by a small sinus continuing as a broad and short furrow beneath the umbo. The upper valve sculptured ontwardly with two furrows close to the upper margin and a diagonal curved impression dividing the valve into a convex anterior and a flattened posterior part; the anterior half sculptured by very fine raised irregular striae or rows of granulae and concentrically irregularly rugated, with some distant lines of growth. 'The lower valve sculptured with two furrows close to the upper margin, some lines of growth and extremely fine granulae, for the rest smooth. Inside of the shell nacreous; the upper valve in its upper part radiately plicated, the lower valve smooth. Pallial line simple; anterior muscular sear much lengthened, the posterior one short. Ligament represented both by a feeble thickening of the exterior cuticula and by an interior resilium transformed into a free ossicle attached into a small hole on the inside of each valve. Hinge consisting of a small knob-like tooth in the upper valve, fitting into a socket of the lower one, bounded by a raised margin. Dimensions: 
height from superior to inferior margin $21.8 \mathrm{~mm}$, breadth $15 \mathrm{~mm}$; breadth of the attached area of the inferior valve $11 \mathrm{~mm}$; breadth of the reflected (free) part of the same valve $12 \mathrm{~mm}$; crassitude of the mussle (valves closed) $15.5 \mathrm{~mm}$.

Locality: 42 miles W. S. W., 60 feet $(\% / r), 1$ sp., h. $21.8 \mathrm{~mm} ; 45$ miles W. S. IV., 72 feet $\left({ }^{11} / 8\right), 2$ sps, from Ascidiac and from a Melcagrina, h. 13 (with animal) and $7.5 \mathrm{~mm}$ (dead).

Animal (fig. 5) with the mantle closed all round except the short siphons; gills two on each side, the posterior one with its descendant lamella reduced and only the reflected one retained, highly expanded, with its superior margin free; the inner gill with both lamellae well developed; in the large specimen both pairs of gills were completely free of each other and of the mantle posteriorly; in the smaller one they were joined to each other behind the foot and fused with the edges of the mantle. Foot triangular, very short, laterally compressed, with a small cutaneous Jobe behind; labial palps elongated linguiform, not nearly reaching the middle of the adductor. The large shell was attached to a Cardita, the sculpture of which is repeated, not only on the inside of the lower valve but also on the outer side of the upper one, thus causing here a false or occasional sculpture in the form of a coarse rugation that is wholly absent from the smaller specimens. Also in the hinge struction, the large specimen is aberrant, inasmuch as the tooth of the left valve has been nearly entirely reduced, which has been compensated by a strong development of the socket margin in the right valve and an irregular rifling on its upper side, thus causing its striking similarity to a true tooth.

In general appearance the present shell reminds one strongly of a member of the family Chamidae, especially of the genus Pseudochama, in respect of its attachment with the right valve. SChama fimbrialas of REEvE (Conch. Icon. 4, fig. 41) which is recorded from Port Cunningham and Geraldton (cf. HedeEy 1916) is much similar to it, but the description is too uncomplete to allow identification. The presence of an interior ossicle and the aberrant construction of the hinge make it, however, evident that the form before us is to be referred to the genus Chamostrea, which has hitherto comprised only one species, Ch. albida LAMAnck, from the east coast of Australia. The new form differs distinctly from the type of the genus in the presence of plicae in the interior of the left valve, as well as by its smaller size. With regard to the soft parts of the animal, the new form shows some other differences from the type in its gills being free of each other (Chamostrea albida has them united posteriorly), ${ }^{1}$ and by the absence of a pedal opening as a consequence of the complete coalescence of the mantle margins in front of the siphons.

Basing themselves on the shell characteristics, the systematists have included the genus Chamostrea (generally made the representative of a distinct family) eitluer with the group Anatinacea, on account of the struction of the ligament, or with the group Chamaced, with respect to its similarity in the outer habitus and its mode of attachment, with forms of the family Chamidae. It is true that among this family

1 This condition may perlaps be subject to individual variation, as is the case in the forms of Chamiduc. 
only we meet with forms fixed as Chamostrea with the anterior half of the right valve and the hinder half directed upwards (an attachment similar to that of 1 'seudochama cristella and $P$. retroversa) and that among the Anatinacea no pleurotethic forms exist which are similar to Chamostrea and speak in favour of its reference to this group. Even the animal of Chamostrea seems to repeat the conditions of Chamidce by its reduced foot, its coalesced mantle, and the position of the gills (cf. ANTHONY 1905).

A close examination of the exterior and interior morphology of Chamostrea, for which I have taken the present specimens as subject, will show, however,

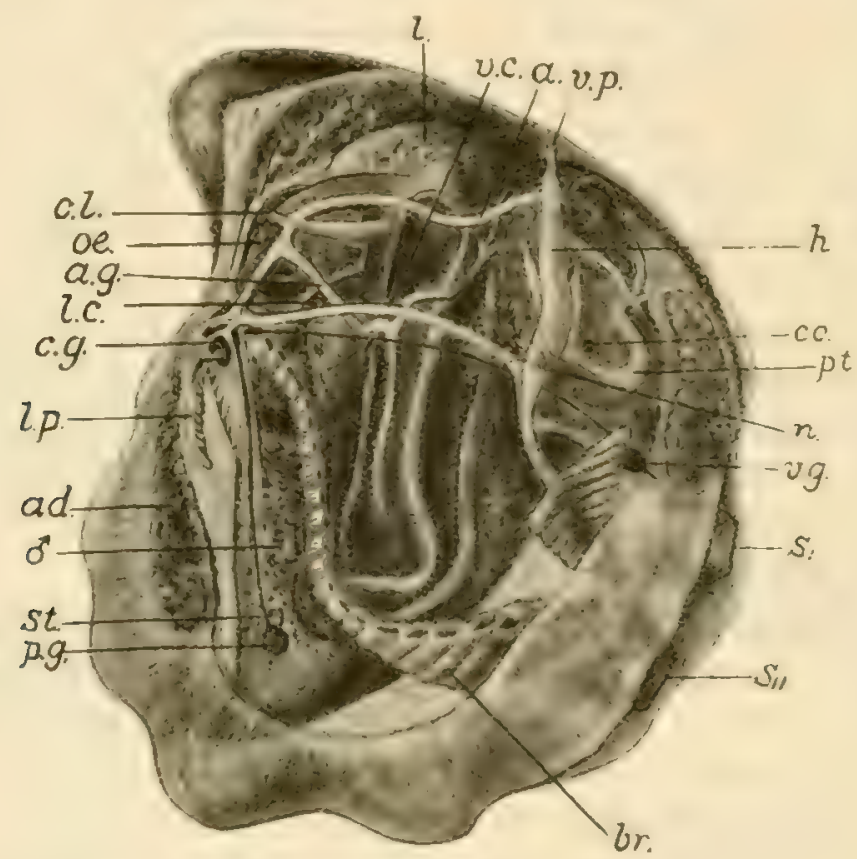

Fig. 5. Anatomy of Chamostrea plicifera n. sp., reconstructed from sections, a. norta anterior; ad. adductor anterior; a. g. arteria gastrica; br. gill., c. g. cerebral ganglia; c. $l$. lateral coecal process; co. commissure between nephridia; $h$. heart; $l$. liver; $l$. $c$. liver canal; $l$. $p$. labial palps; n. nephroproct, in front of it genital pore; oe oesophagus; $p . g$. pedal ganglia; $p$. $t$. pericardia tube of nephridia; $S I_{\text {, }}$ SII anal and branclaial siplons; st. statocyst; v. c. vena cava; v. g. visceral ganglion; v. $p$. vens pallialis; o malo genital organs.

that the resemblance to Chamidae is a mere parallelism and that the relationship must be sought in Anatinacea.

The small valves of $C h$. plicifera present in the collection allow an examination of the umbonal part of the free as well as the attached valves. If the form were a member of the Chamidae, we should expect to find its nepionic shell corresponding to that of a Pseudochama, i. e. to be of a rounded shape and furnished with widely separated projecting lamellae. But this is not the case; on the contrary, its outline is triangular, the umbones occupying the apex of the triangle, and its surface sculptured with close thread-like concentric ridges, more distinct on the upper than on the lower valve. The nepionic shell thus resembles that of IIyochama, a genus of Anatinidae likewise confined to Australia and attached by its right valve. 


\section{Anatomy of Chamostrea plicifera.}

In the inner organisation (fig. 5), Chamostrea exhibited many peculiarities. Considering first the intestinal canal, we find the stomach in its dorsal part extended transversly; further down it widens in its central part, but keeps a deep furrow on each side. The left one soon becomes separated from the stomach proper and extends as a coecal appendage (fig. $5 \mathrm{col}$.) towards the front; the right furrow also gives rise to a coecum, which is, however, much shorter. The central or pyloric part of the stomach gives off a short, median, anterior, descendent, principal liver duct $\left(l . c_{0}\right)$ and passes on downwards as the duodenal portion, showing a very narrow furrow in its anterior side, somewhat to the right of the median line. The chief part of the duodenal portion is occupied by the wide furrow of the crystalline stylet. In this specimen it contained only a cuticula separated from the underlying cylindric epithelium. In the lower end of the duodenum, this sheath of the crystalline stylet widens somewhat to a small sac; this probably marks the first step of a separation into a crystalline coecum. Beneath this sac-like dilatation the intestine emanates, describes a short curve towards the front, and passes by a simple flexure below and behind the duodenum towards the dorsal side of the pericardium, and then continues as rectum to the anus on the hinder side of the posterior adductor.

The liver (l.) occupies the central part of the visceral hump in front and at the sides of the upper part of the duodenum and of the stomach. From its upper portion there debouch two separate anterior and one posterior liver duct into the right part of the stomach and from its lower portion the somewhat larger principal liver duct leads to the left side of the cardiac part of the stomach.

The oesophagus (oe.) has its walls folded just above the mouth; well towards the interior they become smooth. The labial palps $(l, p$. $)$ are strongly folded.

The gills and the circulatory organs (fig. 6 ). As mentioned, there are two demi-branchs on each side of the body, the posterior one consisting of only one lamella, the anterior of two, as usual. The posterior demi-branch is to be considered as originating in such manner that its descendent lamella is probably greatly reduced in size in analogy with the conditions prevailing in Pisidium. In their detailed organization the gills in many respects recall those of Chama: the anterior demi-branch has a marginal furrow in its under free margin, and each lamella is plaited, the largest folds containing about 18 filaments, and lastly the principal filaments contain alternately afferent and efferent blood vessels. But by a study of the organization as a whole, essential differences between the present species and a Chama are to be established. It is not sufficient to examine a single section through the gills to gain an idea of the detailed organization and the combinations of filaments and lamellae. We must also consider in what manner the blood vessels enter into and leave the respiratory organs, and not until such an examination has been made can the complete structure of these organs be revealed and exhaustively compared with that of other forms. 
Just in the respects named are the most fundamental divergencies between the Chamostrea and the Chama gill. In Chamostrea all afferent vessels enter into the principal filaments out from the branchial axis, and to the same axis all efferent vessels run, debouching into the branchial vein or efferent trunk, which carries the blood back again to the heart. As all blood thus emanates from the renal sinus, no marginal veins, which are present in the reflected lamella in Chama, exist in Chamostrea. A further difference lies in the development of the interlamellar septa. These are complete only between the afferent vessels in Chamostrea, whereas they are high also between the efferent vessels, though not so long, and they terminate somewhat sooner, in Chama (cf. fig. 6).

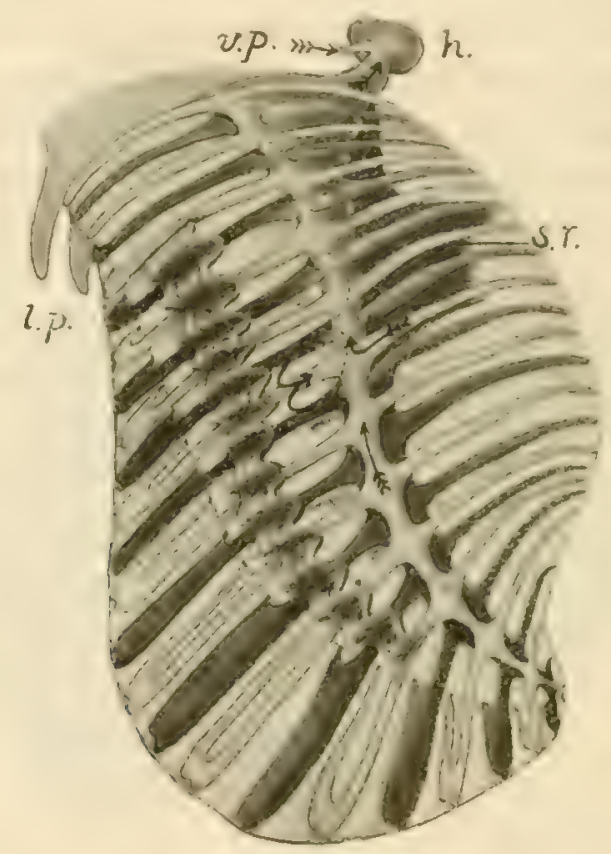

1ig. 6. Scheme of the intra-branchial blood circuit. Dark venous, lighe arterial interlamellar vossels; some plaits of the extorior lamella and the extonsion of the interior ono shown. $h$. heart; $l$. $p$. labial palps; s. $r$. sinus renalis; $v$. $p$. vona pallialis.

As to the minute structure, no differences prevail; in Chamostren, just as in Chama, there are interfilamentar junctions and as a consequence of their existence both the anticlinal sides of a fold always contain blood of opposite nature (venous in the one, arterial in the other side).

Being a breathing organ, the purpose of which is to serve the circulatory system, the organization of the gill can be wholly understood only in combination with the circulatory system, a fact of importance to remember in anatomical investigations of lamellibranchs.

The extra-branchial blood system. The heart of Chamostrea (fig. 5h.) is situated beneath the rectum, from which it is further separated by interjacent ovarial folliculi. Its ventricle is compressed from the front and behind and extended in a transversal direction. Trom its central part lobes project on each side of the 
rectal region, the largest being the right one. From the left lobe emanates the anterior aorta $(a$.$) , separated by a valvule from the ventricle, and from the posterior$ side of the central ventricular portion, somewhat to the right of the median line, the posterior aorta appears. As to the anterior aorta, this runs subcutaneously in the left body side out of the stomach and the oesophagus. From its oesophageal portion it gives off a branch $(a . g$.$) to the upper part of the duodenum, which branches$ on the one hand to the hinder side of the stomach and to the intestine, and on the other gives rise to two vessels running along each side down the duodenum. In Chamostrea, thus, the arteria gastrica emanates in a quite different manner from that in Chamidae (cf. above). Close above the mouth, the anterior aorta bifureates into 1) a branch penetrating on the left side of the oesophagus forewards to the anterior adductor and the mantle (no corresponding vessel occurs on the right side) and 2) the arteria pedalis, which follows the pedal nerve cords down into the foot. The posterior aorta runs between the two nephridia down on the anterior side of the adductor posterior and sends out a vessel which follows the under side of the rectum posteriorly.

The venous blood system begins among the viscera, from where two principal trunks converge towards the region of the mouth; an upper one from the umbonal region and a lower one from the foot. To the lacunae that are formed by them on each side of the oesophagus also join veins from anterior adductor and mantle. From the oesophageal region the blood is carried away by a trunk (v.c.) running laterally along each body side, the largest one being the left, and this debouches directly into the renal sinus on the base of the gill axis. Before its entrance here it receives veins from below.

This lateral vein is homologous to that vessel in Chama, which runs beneath the fixation line of the exterior lamella of the anterior demi-branch and, further back, is contained in the free margin of the reflected lamella. Which condition may be the primary one, that of Chama or of Chamostrea, is a question impossible to answer until a comprehensive inquiry into the circulation within the lamellibranchs has been carried out.

From the hindermost part of the body all venous blood is carried away to the renal sinus and from there arrives directly into the gills (cf. fig. $6, s_{0}, r_{\text {. }}$ ).

The mantle has its own closed circulation inasmuch as a special pallial vein $(v . p$.$) leads the blood from the upper part of the mantle directly into the auricles.$

The genital organs. Chamostrea is hermafroditic. The uppermost part of the visceral hump is occupied by the ovarial folliculi, which penetrate somewhat backwards between the rectum and the pericard. Down on the side they reach about the lateral vein. The present specimen had great masses of mature eggs, the largest measuring $0.17-0.20 \mathrm{~mm}$, and each surrounded by a thick cuticula.

Somewhat below the lateral vein the spermatoid folliculi begin to appear, but they pentrate farther upwards in the surroundings of the intestine. They also were filled with wholly developed genital products.

Hermaphroditism is a peculiarity that Chamostrea shares with all other Anatin- 
acea. Among them it takes a special position in the respect that both male and female organs have a common exterior opening, situated just beneath the end of the pericard and just opposite to the nephroproct $(n$.$) . It is a simple pore with some-$ what projecting margins.

The nervous system. A remarkable fact is the presence (just as in Chamidae) of a large and distinct buecal ganglion behind each cerebral centrum, connected by means of a distinct and continuous suboesophageal commissure to that of the opposite side. The right cerebral ganglion is situated higher up than the left one, as a consequence of the mode of attachment of the shell. For the rest, the nervous system exhibits no peculiarities. There is no median commissure between the cerebrovisceral connectives in front of the perieard, as in Chamidae. 'The pedal cords are very feeble and the pedal ganglia are coalesced to a single centre.

The nephridia. These are situated behind the pericard and before the posterior adductor and are extended in a dorso-ventral direction from the side of the rectum down to the visceral ganglion. The right one lies somewhat higher than the left, as a consequence of the inequilaterality of the body. Each external sac is heavily and minutely lobed in all its outer walls, but the inner (median) wall is even. The epithelium lining the external sac forms a simple layer and each cell is occupied by a large rounded concretion of a deep brownish colour; all such particles are of uniform size. The external sacs debouch into the mantle cavity by means of simple pores (fig. $5 \mathrm{n}$.) with muscular margins opposite and close to the genital orifices, and are in very short communication $(c o$.$) with each other above the peri-$ cardial tubes. 'These $\left(p . l_{0}\right)$ emanate with rather long, strongly ciliated funnels from the lateral corners of the pericardium; the funnels converge inwardly, widen somewhat to a sort of ampullae with smooth and even walls lined with ciliated epithelium, which are continued upwards by the very narrow pericardial tubes; these run, slightly winding, turned towards each other and separated only by the renal sinus, till they debonch into the upper third of the external sacs.

As a whole, the nephridia of this species are very similar to those of Chamidae, especially of Pseudochama, but they differ in the smooth-walled ampulla, the somewhat shorter pericardial tubes, and the presence of large concretions in the external sacs. The mentioned characteristics are confined to forms of Anatinacea (Pandora, Lyonsia, Thracia), from which, however, the short communication of the external sacs serves to distinguish the present form (cf. OdInER 1912).

Sensory organs. Immediately above and without the pedal ganglia are to be found the large statocysts (fig. 5 st.). They each contained large statolith and many small statoconia. The co-existence of these features is characteristic of Anatinacea. The statoconia showed the peculiarity of being assembled in the upper left part of the statocyst, either as a result of the right-sided fixation or else due to some temporary conditions at the moment of the preservation.

On the right side of the body there was to be observed a well-developed sensory organ, situated on the mantle just at its junction with the siphonal fold and extending from the median part of the inspiratory sipho up to the outer base of the 
right nephridium, as far as to the upper side of the visceral ganglion. It consisted, as far as could be seen, of epithelial plaits clothed by very high cylindric cells with contents deeply tinted with haematoxylin towards the exterior ends. It was innerved by the posterior pallial nerve.

On the general place of the osphradium at the base of the gill axis no specialization of the epithelium and its innervation was to be observed.

MLuscles. Besides the two adductors, of which the anterior one (ad.) is longer than the posterior, as the muscular impressions on the shell indicate, there exist the pallial and the siphonal muscles, as well as the foot retractors. The last-named are much reduced as a consequence of the vestigial nature of the foot. They emanate as a single cord from the musculature of the visceral hump and penetrate the nephridia in front of the visceral ganglion. They soon disappear, still as a single cord, in front of this ganglion long before arriving at insertion in the shell.

\section{b. Gastropoda.}

\section{Prosobranchia.}

\section{HAH. FISSURELLIDAE.}

Glyphis jukesi Rerve. 45 miles $W$. S. W., 66-84 feet $\left({ }^{1} / 6,{ }^{14} / 7\right)$; and 42 miles W. S. W., 60 feet $\left({ }^{10} / \%\right)$, many sps, max. $1.35 \mathrm{~mm}$ (the latter locality). Distribution: Gulf of Oman: Ormara Bay (Melvill \& STANDEN 1901); all round the coast of Australia (Pilsbry 1890, Hedeer 1910).

G. singaporensis REEVE. 45 miles W. S. W., 70-72 feet $\left({ }^{14 / 7}\right), 2$ sps, max. 1. $16 \mathrm{~mm} ; 42$ miles W. S. IV., 70 feet $\left({ }^{25} / 5\right), 1$ sp., $1.17 .5 \mathrm{~mm}$. The specimens agree in shape, colour, and sculpture, with figures 100 and 101 in REEv's Conch. Icon. 6, 1850. Most characteristic are the indistinct broad radii, to the number of 8 , best visible towards the margin, and the rather fine latticed sculpture, in which the radiating ribs dominate over the concentric threads. On the inside the radii shine through; here there appear also fine, opaque, white radiating lines such as PILSBRY (Man. of Conch. XII, 1890, p. 219) mentions. Distribution: Singapore (REEve), Maldives and Laccadives (E. A. Sintr 1903), Andaman Isl.; Chagos Archipelago (MELVILL 1909), Queensland (HEDLEY 1910).

G. quadriradiata ReEve. 45 miles W. S. W., $60-66$ feet $\left({ }^{15} / 7\right), 3$ sps, max. . $14.3 \mathrm{~mm}$. The specimens are quite similar to fig. 108 by REEVE (Conch. Icon. 6 Fissurella) in their very characteristic colouration (4 rays forming a cross) and the shape of their foramen, which has excavated sides, in which it differs from $G$. riipelli, which is, further, more elevated. The largest specimen had, besides the 4 dark cross rays, a greenish tint towards the margin, and some of its costae were stained with purple. 'The under margin is crenelated in an alternating manner, so that between two deep slits there is one median shallower, and on both sides of it 
one still smaller notch, the largest incisions corresponding to the coarsest purplestained costae. On the inside the colour shines through. - PiLsBry does not include this species in his Manual of Conchology, Vol. 12, 1890. REEvE records it from the Philippines, and HEDLEY (1910) from Queensland.

Emarginula galericulata A. ADAMs (Pl. 1, figs. 33-35). 45 miles W. S. WV., 66 feet $(18 / 7), 1 \mathrm{sp}$. with animal, l. 3.6, h. $2 \mathrm{~mm}$. The specimen has a greenish colour and has an apex highly bent posteriorly and a sculpture consisting of dense, radiating, finely nodulous ribs and interjacent elevated concentric lines in the interstices. The frontal rib is composed of a series of noduli, separated by pits; the distances between the noduli is $>$ the breadth of the rib. 'The figure given by Sowerby in Thes. Conchyliorum 3, pl. 246, fig. 24, shows only indifferently the shape and sculpture, for which reason I give a photograph of the present specimen in which these characteristics are more clearly shown. The species is only known from the Philippines.

Emarginella clupeus ADAMs. 45 miles W. S. W., 48 feet, $1 \mathrm{sp} .\left({ }^{8} / 7\right), 1.35 \mathrm{~mm}$ (animal), $24 \mathrm{~mm}$ (shell), and $1 \mathrm{sp} .\left({ }^{16} / 8\right), 1.15 .5 \mathrm{~mm}$ (shell); 66 feet $\left({ }^{20} / 7\right), 1 \mathrm{sp} ., 1.12 \mathrm{~mm}$ (shell). The colour was either light rose (sp. 3) or white (sp. 2), and in the former the shell was uneovered on a larger area than in the latter. - In comparison with the specimen dredged by the Siboga expedition (cf. ScHepman 1908) the present forms have denser sculpture, such as is described by PIISBRY (Manual of Conch., Vol. XII, p. 265, pl. 28, fig. 7). Schepmax has shown that $E$. clupeus belongs to the section Emarginella created by PILSBRY for E. cuvieri (AUDOIN) ISSEL in consideration of its soft parts, which are so voluminous as to be far larger than the shell. Cooke (1885) is of the opinion that E. planulata ADsus from Singapore and E. clupeus from the Philippines are identical with E. cuvieri, and this is scarely to be doubted, as the latter has been shown to belong to the same section. A comparison of the present specimens with the figure of $E$. cuvieri given by SAvignY (Descr. de l'Egypte, Hist. Nat. 2, 'l'ome IX, Pt. Gastéropodes, Pl. 3, fig. 2; Coquilles, Pl. 1, fig. 9) has shown only some slight differences in the sculpture and the place of the apex; the latter is situated more towards the front (subcentrally) in the present ones, and at the posterior third in that of SAVIGNY. The furrow on the front slope is shorter in the present forms than the distance from apex to posterior margin, while in SAvigxy's specimen it is longer, but these proportions are certainly subject to variation, for in the Siboga specimen the furrow is longer than the named distance. - The dimensions of the largest specimens are: shell: 1. 24, br. 16.3, h. at the middle $5.5 \mathrm{~mm}$; animal: 1. 35 , br. 28, h. $10 \mathrm{~mm}$. - Schepman's $L$. sibogae is probably only a variety of this species; it has 12 epipodial filaments on each side, while the present one has more than 20; but this difference is probably due to the different sizes of the respective specimens. In SAVIGNY's specimen there are 38 ribs on the shell and 15 epipodial filaments on each side of the animal.

Scutus unguis IIINNÉ. 42 miles W. S. IV., 42 feet $(10 / 7), 1$ sp., 1. 30 (shell), 36 $\mathrm{mm}$ (animal); 70 feet $\left({ }^{20-31} / 6\right), 6 \mathrm{sps}, \max .1 .27 \mathrm{~mm}$ (shell); 45 miles $\mathrm{WV}$. S. W., 66 
-80 feet $(1 / 7,15 / 7), 4$ sps, $\max .1 .18 \mathrm{~mm}$ (shell). The colour of the largest animal is light brownish with black dots, which are confluent to radiating stripes. The distribution is very wide: from Persian Gulf and Red Sea to Cape of Good Hope, Japan, Philippines, New Caledonia, and Australia (Melvill \& Standen 1901, PilsBRY 1890).

FAM. STOMATELLIDAE.

Gena strigosa A. Aduss, var. minor n. var. (Pl. 1, figs 36, 37, text fig. 7). 45 miles IV. S. W., 66 feet $\left({ }^{15} / 7\right), 2$ sps, max. 1. 7.5, br. 4.3, h. $2.4 \mathrm{~mm}$; whorls 4 . The two specimens differ neither in colour (light reddish, alternating dark red and yellow spots at the suture and the columellar margin) nor in sculpture (dense, unequal striae, higher up elevated threads) nor in shape from the typical G. strigosa

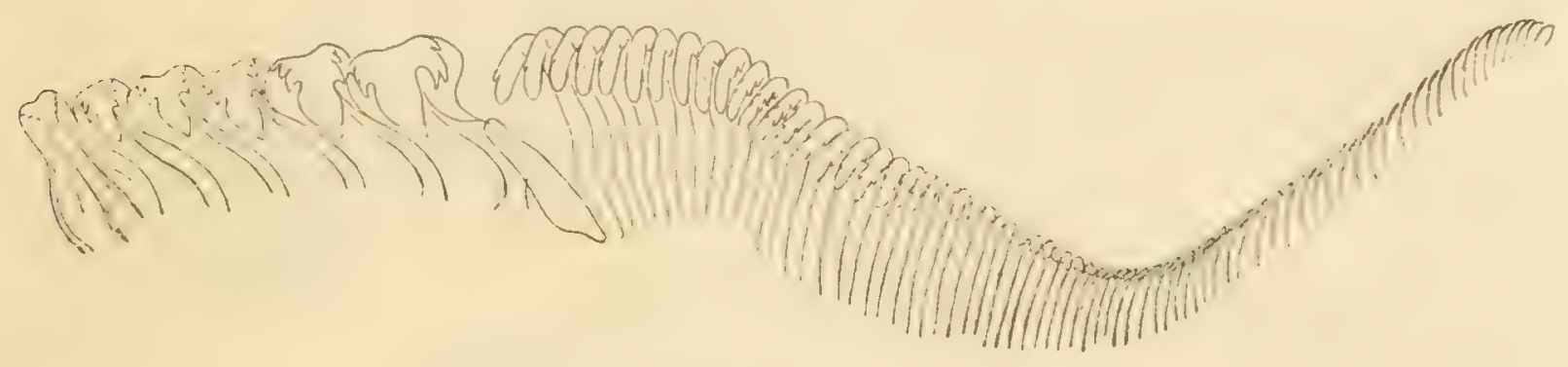

Fig. 7. Radula of Gena strigosa var. minor. $\times 200$.

from Port Jackson (specimens in R. M. compared), only the size differs, inasmuch as the type measures about $10.5 \mathrm{~mm}$ in length and $6.3 \mathrm{~mm}$ in breadth by 4 whorls; when smaller it becomes even broader relatively to its length. - The animal of the present variety has a strong foot with short fringed epipodial cirri; further there exists on each side of the neck a swater conduit, characteristics which are confined to the subgenus Plocamotis Fischer according to PiLsBry (Man. of Conch., Vol. XII, 1890). The typical G. strigosa is only known from Port Jackson and from the Chagos Archipelago (MELvild 1909).

The radula (fig. 7) has the formula $\infty .1 .5 .1 .5 .1 . \infty$. Median tooth with a small apex and 3 denticles on each side of it; the laterals increasing in size outwardly, each with 3 denticles on the sides of their cusps; in the outermost lateral the two anterior denticles in the outer edge are united; outside the laterals an incomplete transitional tooth; uncini more than one hundred, the inner ones with large spoonlike heads, with one strong denticle on each side of the base; tooth 10 and the sequent ones with 3 or more denticles, which, like the apices, successively diminish in size and increase in number; teeth from about 60 with reduced apices and smooth, abruptly truncated upper ends. 


\section{FA.TROCHIDAE.}

Trochus fenestratus Gablix. 45 miles W. S. W., 60 feet $(8 / 7), 1$ sp., h. 3] mm. The species differs from $T$. architectonicus in having considerably lower and distant tubercles (about 17 on a turn of the last whorl) - $T$. architectonicus has about 40 - and 5 distinct spiral lines of small tubereles on the last whorl. The interstices between the large tubercles are red in the present specimen. Distribution: Indian Ocean to Philippines, Viti Isl., Queensland (PILsiry 1889, HedLey 1910).

Euchelus atratus Girin. 45 miles W. S. W., 66 feet $(15 / 7), 5$ sps, max. 1. 17.5 $\mathrm{mm}$, overgrown with a spongia; a small sp., h. $6.4 \mathrm{~mm}$, not full-grown, deep rose, still only a very small, scareely visible rudiment of a columellar tooth; 42 miles $\mathrm{W}$. S. W.,

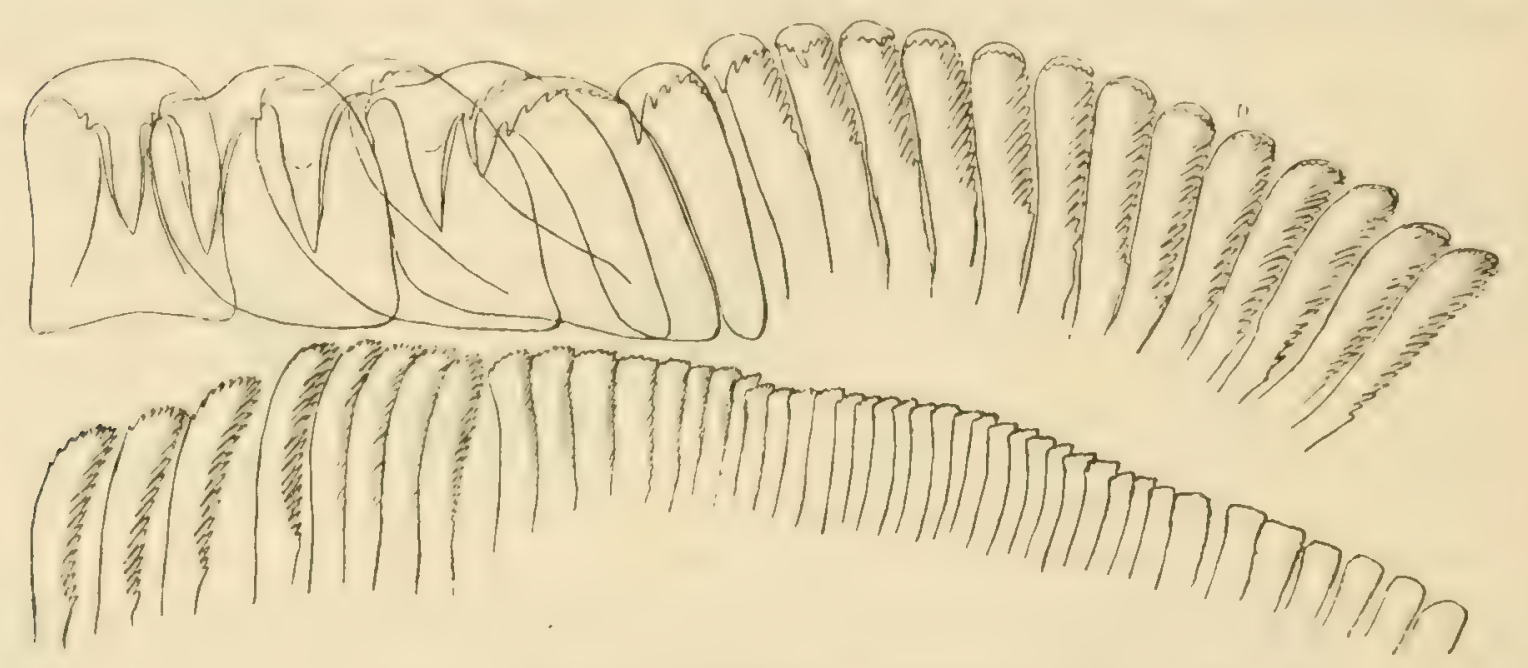

Fig. 8. Radula of Euchelus mysticus P'1LSBRY. $\times 320$.

66 feet $\left({ }^{11 / 7}\right), 2$ sps, max. h. 7, the one marbled with brown, the second grayish yellow-red; tooth very feeble but distinct. - 42 miles W. S. W., 42 feet, 1 sp., h. $16 \mathrm{~mm}$. - Distribution: Karachi (NeLvild of Standen 1901); Red Sea, Indian Ocean (L. A. Smitr 1891); Philippines; Viti Isl. (PILsury 1859); Queensland (Hediey 1910); Victoria (Pritcilard \& GathifF 1901), N. W. Australia (Brazier 1885).

E. mysticus PrLsbry (PI. 2, figs. 38, 39; text fig. 8). 45 miles W. S. W., 66-70 feet $\left(3 / 6,{ }^{20} / 8\right), 2$ sps, max. h. 12.6, br. 13 , and h. 11.6, br. $13.2 \mathrm{~mm}$; whorls 5 . They agree, though of smaller size, with the description and figure given by I'ILsizr 1889 (Man. of Conch. 11, p. 444, pl.57, fig. 7). 'The specimen described by PrLsnix was from Singapore.

The animal has an epipodial lamella all round the foot, with dense digitiform processes in its edge; the head bears two fringed lobes between the tentacles, which are set off from the body by their black colour; eyes pedunculate at the outer sides of the tentacles. 
Radula (fig. 8) $\infty .1 .3 .1 .3 .1 . \infty$. Inner teeth of the radula very uniform; median tooth and the first two laterals with a long cusp and 2 small denticles on each side of its base; third lateral with 3 or 4 denticles; transitional tooth vestigial; uncini much elongated, about the first 10 like the laterals with an increasing number of denticles and successively obliterating cusps; the nearest following ones with reduced cusps and pectinated outer edges; the outermost uncini more ereet and with serrated, then smooth, edges of the abrupt upper ends.

Turcica maculata Brazier. 45 miles W. S. W., 48 feet $\left({ }^{16} / 7\right), 1$ sp., h. 13 mm. - The species was previously known from Cape York, south N. Guinea, and Iorres Straits (PrLsbry 1889).

Delphinula distorta Linné, var. zonata n. var. (Pl. 2, figs. 40, 41; text fig. 9). 45 miles W. S. W., 60-80 feet $\left({ }^{13} / 8\right), 2$ sps. Shell depressed, widely and openly umbilicated, mouth wide, circular, with the outer margin projecting above. Spire with 3-4 flattened whorls with slight undulations and a sharp angular keel, tubercled at certain intervals. Last whorl with about 10 produced spines on the angular kcel, above it with 3 (towards the mouth 5) spiral rows of smaller spines, directed forwards, and below the angular keel with 8 (towards the aperture 9) equal rows, the last one bounding the umbilicus; even within the umbilicus $3-4$ rows of spinules. Colour: shell banded with brown, whitish yellow and red: a broad dark brown band on half the breadth of the upper surface of the whorls, the spines and a zone beneath the angular keel down to half the height of the whorl, light reddish; umbilicus deeply down and the spine rows within and around it dark brown; for the rest yellowish white. Mouth inwardly whitish, iridescent. Upper whorls light reddish with a deeper tint in the periphery, and with the brown band tapering upwards as a sutural line. Operculum horny brown, multispiral. Dimensions: max, height 23, br. 27.5, h. of aperture outwardly 17, inwardly about $15 \mathrm{~mm}$. - This variety differs from the typical $D$. distorla Linné chiefly in the upper surface of the last whorl being spinous, while it is destitute of spines and only spirally lirate in $D$. distorta. In one of the two specimens the brown as well as the red zone were more expanded and the rows of spines more numerous with smaller and denser pricks (11 rows between the angular keel and the periumbilical spiral). The specimen (Pl. 2, fig. 40) exhibited also a trace of longitudinal folds on the upper part of the whorls. It carried 2 specimens of Crepidula aculeata with a sculpture of fine prickles and even in its brown colour closely resembling the Delphimula. - The dark umbilicus is a characteristic that this species has in common with the West Australian D. Iyrin REEvE as well as with certain colour variations of D. delphimulus LINNÉ (laciniala LAMARCK). - Distribution of the typical form: Indian Ocean, Nicobar Isl. ('I'RYoN 1888, Man. of Conch. 10); Japan (R. M.).

The radula has the formula $\infty .1 .5 .1 .5 .1 . \infty$ (fig. 9). Median tooth broad with a straight, abrupt edge; the first three laterals with small conical apices, the two outer ones with highly enlarged cusps, the first of them with one, the second with two small denticles in the onter side of the base; transitional tooth with a 
moderate conical apex and denticulations on each side of its base; uncini about 37 in number with short spoon-like heads, which are bilaterally denticulated and gradmally decrease towards the sides. - The radula differs from that of $D$. atrata ('Troscini, 1879, 'Taf. XXI, fig. 8) and that of D. sphaerula (Scinermas 1908, pl. IX, fig. 3) only in having two denticles at the base of the cusp in the outermost lateral.

\section{FAII. NATICIDAE.}

Natica zebra LAMARCK. 42 miles IV. S. W., 70 feet $(26 / 5), 1 \mathrm{sp} . \mathrm{h} .5 .5 \mathrm{~mm}$. Corresponds perfectly with specimens from the Philippines in R. M. - The Siboga Expedition found this species in the Java Sea (Screprus 1909).

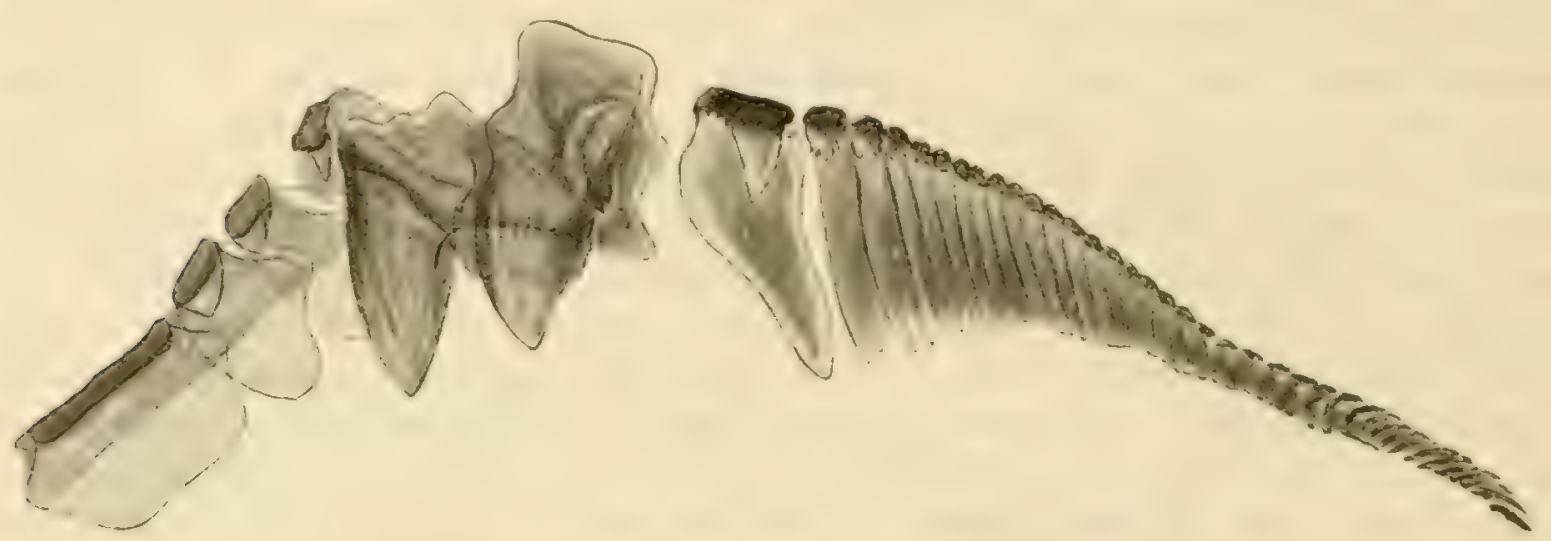

Fig. 9. Radula of Delphinula zonata n. sp. $\times 90$.

Vanikoro clathrata Recluz. 45 miles W. S. W., 70 feet $\left({ }^{3} / 6\right), 1 \mathrm{sp}$, , h. and br. $5 \mathrm{~mm}$; 42 miles W. S. W., 70 feet $\left({ }^{25} / 5\right), 1$ sp., h. and br. $8.8 \mathrm{~mm}$. Recorded from Persian Gulf and Mekran coast (Meivill \& STANden 1901), Queensland (HedLeY 1910), I. Bourbon and Polynesia (Trron 1886).

\section{FAH. HIPPONYCIDAE.}

Hipponyx australis Quor \& Gamard. 45 miles W. S. IV., on the spines of a Cidaris, 1 sp., $1.4 \mathrm{~mm}$. - Distribution: Maldives, Ceylon, Andaman IsI. (E. A. Surti 1903); Mauritius to Japan, Viti Isl., and New Zealand ('T'RYox 1886); Victoria (Pritchard \& GateifF 1899); W. Australia (Heder 1916).

\section{FA. II. CAIULIDAE.}

Crepidula aculeata Gulsin (Pl. 2, fig. 40). 45 miles IV. S. W., 80 feet $(29 / 6)$, 1 sp., 1. $20.5 \mathrm{~mm}$ (like C. echinus Broderip; ef. 'I'ryon, Man. of Conch., Vol. VIII, 1856, pl. 39, fig. 63); 72 feet $\left({ }^{11 / 7}\right), 1$ small sp., 1. $3 \mathrm{~mm} ; 45$ miles W. S. W., 60-S0 feet $\left({ }^{13} / 7\right), 2 \mathrm{sps}$, max. $1.13 \mathrm{~mm}$, on the larger specimen of Delphinula distorta var. 
zonata (Pl. 2, fig. 40). - East and west coasts of America; Japan, India, Australia ('T'ryon 1886); W. and S. Africa (v. Martens 1903); N. Kealand (Suter 1913).

C. (Siphopatella) walshii Hermanssen. 45 miles W. S. W., 48 feet $(5 / 8), 1$ sp., 1. $17 \mathrm{~mm}$. This characteristic species, which has the internal shelf tubular at the columellar margin, is known from Ceylon, Singapore, the China Sea, and Japan ('TrYon 1886, Man. of Conch., Vol. VIII; V. NAR'TENS 1886).

Capulus badius Dunker. 42 miles IV. S. IV., 70 feet $\left({ }^{25} / 5\right), 1$ sp., $1.10 .5 \mathrm{~mm}$, aperture 1. $7.2 \mathrm{~mm}$; the breadth of the shell (=apertire) $5.7 \mathrm{~mm} ; \mathrm{h} .5 \mathrm{~mm} ; 45$ miles W. S. W., 48 feet $\left({ }^{16} / 8\right), 1$ sp., $1.4 \mathrm{~mm}$. The specimens, which are orange coloured also within the aperture, correspond closely to figs. 15, 16, 17, Tab. XIII in DUNKER 1882, but lack the expansion of the lip on the left side of the aperture.

- Distribution: Japan.

\section{FAM. CERITHIIDAE.}

Cerithium (Vertagus) attenuatum Phiıp', var. brevicaudatum 11. var. (PI. ¿, fig. 42). 45 miles $W$. S. W., 70 feet $(2 / r), 1$ sp., $1.33 .5 \mathrm{~mm}$. The specimen differs only in having a shorter canal bent sharper towards the rear (its length about ${ }^{1 / 3}$ of the largest extension of the aperture) from the type figured and described by Pinlirpi (Abb. neuer Conch.; Tab. 1, fig. 2, Cerithium). The length of the canal is certainly subject to variation, for REEVE figures it shorter than does PIILIPPI (REevE Conch. Icon., Vol. 15, 1866, Vertagus. sp. 12). The species is known from the Philippines (Tryon 1887) and from the Mekran coast (Melvill \& Standen 1901).

Cerithiopsis crocea ANGAS, var. marmorea n. var. (Pl. 2, fig. 43). 45 miles W. S. W., 66 feet $\left({ }^{15} / 7\right), 1$ shell, 1. $9 \mathrm{~mm}$. Apical whorls defective; colour variegated with white and reddish brown dots; in other respects quite agreeing with the figure given by ANGas (Proc. Zool. Soc. London 1878, t. 1, f. 13). Recorded from Port Jackson and Viti Islands ('Tryon, Man. of Conch. IX, 1887), as well as from Tasmania (Hedley $1908 \mathrm{~b}$ ). A decollated specimen from Port Phillip containing 8 whorls was $17 \mathrm{~mm}$ in length (Pritchard \& GatlifF, 1900).

Triphora bicincta n. sp. (Pl. 2, fig. 44). Shell pyramidal, with acute apex and flattened whorls, sculptured with 8 series of tubereles, the two upper ones dark brown, the third whitish. The last whorl with a further angular (white) and a basal (brown) tubercle series. The median row of tubercles smallest, and disappearing on the upper third of the shell, the 9 upper whorls carrying only 2 series of tubercles; protoconch (comprising 5 whorls) dark brown, its 2 apical whorls smooth, its 3 lower ones sculptured with 2 spiral threads and close longitudinal folds, the 3 sequent whorls uniformly white - then the upper brown spiral line appears, and later on the second one. Canal brown with a thick basal cord. Whorls 14 including the 5-whorled protoconch. Dimensions: h. 6, br. $2 \mathrm{~mm}, \mathrm{~h}$. of mouth about $1.1 \mathrm{~mm}$. Locality: 42 miles W. S. W., 66 feet $\left({ }^{11 / 7}\right), 10$ sps. - This new species is casily recognized by its dark brown apex, and sequent uniformly white portion, beneath 
which the whorls are banded with brown and white. There are 20 longitudinal tubercle series on the last whorl.

Henter (1903), in his studies of Australian Molluscas, Pt. 7 (Proc. Linn. Soc. N. S. Wrales) gives the descriptions and figures of several forms of Triphora from Australia; the characteristic colouration of the present species distinguishes it from them all. Soweriz (1907, Proc. Malac. Soc. London, Vol. VII, p. 301, P1. XXV, fig. S) describes and figures a Triphora fuscozonala from N. Caledonia, with sdark brown bands on each whorl; the gem-like nodules... arranged in two prominent rows with a narrow intervening crenulated ridge; on the last whorl they are smaller and closer, forming six ridges. On the somewhat rough figure one observes that. both the rows of brown tubercles extend up to the apex, for which reason the distinction of this species from the one described here secms to be determined.

\section{FAM.VERUETIDAE.}

Vermetus novae-hollandiae Roussesu. 42 miles W. S. W., 70 feet $\left({ }^{30} / 5\right), 1$ sp.; the diameter of the aperture was $16 \mathrm{~mm}$. The animal has no operculum, so that it belongs to sub-gen. Thylacodes GuETTARD. - Queensland (HEDLEY 1910); Victoria (Pritchard \& Gatlife 1899); W. Australia (Hedizy 1916).

\section{FAM. RISSOIDAR.}

Rissoina (Zebina) tridentata Mrrmud, 45 miles W, S. IV., 66 feet $\left({ }^{18} / 8\right), 1$ sp., h. 8 mm. Outer lip with 3 very feeble teeth, upper whorls with costae. Distribution from Red Sea to Sandwich Isl., and Viti Isl. (Trron, Man. of Conch. Vol. IX, 1857, p. 389); Borneo Bank (Siboga Exp.; Scirepman 1909).

\section{WAM. TURRITELLIDAE}

Turritella cingulifera Sownebr. 42 miles W. S. IV., 70 feet $(3 / 6), 1$ shell, 1.25 mm; agrees with fig. :38, pl. 59 in 'Tryos 1886 (Man. of Conch., Vol. VIII). Distribution: Persian Gulf, Gulf of Oman (MELvilu \& Standen 1901); Arehipelago of East Indies (Scheman 1909); Australia (Trron 1856), Queensland (Hedeli 1910).

\section{FAM. STROMBIDAE.}

Strombus (Gallinula) campbelli Griffiri \& Pidgeos. ${ }^{1} 45$ miles W. S. W., 48 feet $(15 / 7), 1$ sp., $1.27 \mathrm{~mm}$; closely resembling - though young and without exterior lip - the specimen from Broome in its strongly folded spire and spirally striated subsutural band; 42 miles IV. S. IV., 42 feet $(5 / 8), 1$ fragment, $1.43 \mathrm{~mm}$. - Distribution: Cambridge Gulf (Hediex 18S9), Queensland (HedLer 1908, 1910). 


\section{FAM.PYRAMIDELLIDAE}

Pyramidella (Lonchaeus) sulcata A. AdAns, 45 miles W. S. W., 70 fect $\left({ }^{1} 1 ;\right)$, 1 shell, h. $21.5 \mathrm{~mm}$, very similar to $P$ '. teres A. Adums (figured by 'Tryon, Man. of Conch., Vol. VIII, 1886, pl. 72, fig. 82) and with a distinet median sulcus on the last whorl. - Distribution: Red Sea, Mauritius, Australia, Philippines, Sandwich Isl. ('TrYON 1886).

\section{FAM. EULIHIDAF.}

Eulima martinii A. Adans. 42 miles W. S. W., $60-72$ feet $\left({ }^{9-14} / 2\right), 2$ deail shells, max. h. $31.5 \mathrm{~mm}$; 45 miles W. S. W., 54 feet, 1 sp., h. $32 \mathrm{~mm}$; 48 miles W. S. W., 78 feet $\left({ }^{15} / 7\right), 1$ shell, $1.19 .5 \mathrm{~mm}$. The specimens agree very well with the figures given by REeve (Conch. Icon. 15, 1866, fig. 6) and Tryon (Man. of Conch., Vol. VIII, 1886, pl. 68, fig. 90); they have the strikingly pyramidal shape and the feeble angularity characteristic of the species. It is recorded from the China Sea and Singapore (Tryon), from the Persian Gulf (Melvill \& Standen 1901), Lombok and Japan (Schepman 1909).

Mucronalia eburnea Deshayes (PI. 2, fig. 45). On Ophiothrix sp. from Cape Jaubert, 45 miles W. S. W., 70 feet $(1 / 6), 1$ sp., h. $4 \mathrm{~mm}$, with 6 whorls, and in entire agreement with the figure in DeshaYes 1863 (Conch. Réunion) in the convex whorls. Scriepman (1909) records this species from the Arafura Sea (Siboga Exp.).

M. variabilis Schepman (Pl. 2, fig. 45). Together with the preceding form on the same specimen of Ophiotrix from 45 miles W. S. W., 70 feet, 1 sp. h. $2 \mathrm{~mm}$, wh. 5. This specimen is attached somewhat above the preceding one. As it carries a distinct operculum but no false mantle, and as its form is in entire agreement with $M$. variabilis figured and described by Schiepuan 1914, I do not hesitate in referring it to this species, though the mode of parasitism in the present specimen is different from that of the typical ones, which were found as ecto- and intestinal parasites on a Synapta from Zanzibar. Of the genus Mucronalia most species are found on Ophiurids or Echinids (cf. Scheprian 1909), but none of them correspond to the present form as much as does $M$. variabilis. The shell of the specimen before me, though young, shows the same configuration of the apex and the same convexity of the two sequent whorls, as well as a similar constriction beneath the suture of the body whorl, as Scrismin describes. Further, the produced shape and the protracted median part of the outer lip are exactly the same in both forms.

\section{FAM. TRITONIDAE.}

Cymatium australasiae Perry (= Triton olearium Auct., not Lixxé). 4in miles W. S. W., 70 feet $(1 / 6), 1$ sp., h. $20.5 \mathrm{~mm} ; 66$ feet $\left({ }^{9} / 7\right), 1$ sp., h. $13 \mathrm{~mm}$. - Though small they show no differences from specimens of the same species from the Mediter- 
ranean, with which they have been compared. - The distribution comprises the whole tropical zone of the world ('Tryos 1881, Man. of Conch., Vol. III, p. 11). A discussion of its nomenclature is given by HEDLEX, 1915.

\section{FAM. TURBINELLIDAR.}

Tudicla inermis Sow ER B Y. 42 miles W. S. W., 42 feet $\left({ }^{15} / 7\right), 1 \mathrm{sp}, 1.31 \mathrm{~mm}$; 45 miles W. S. W., 66 feet $\left({ }^{15} / 2\right), 1$ sp., $1.35 \mathrm{~mm}$. Both specimens agree with the figures given by 'Irrox (Man. of Conch., Vol. III, 1881, pl.58, fig. 410), where there are to be observed 3 folds on the columella; further, they have longitudinal folds or knobs (about 8 on the last whorl) of a yellowish brown colour. 'The species is recorded from Singapore (with doubt by 'I'RYON) and from W. Australia (HedeEY 1916). Both the present specimens were dead and inhabitated by Pagurids.

\section{FAA. FASCIOLARIIDAE.}

Latirus niger n. sp. (Pl. 2, fig. 46). Shell turreted, of a dark brown colour, with a deep-violet aperture; canal produced (more than half the aperture in length). Sculpture: about 8 very broad and slightly elevated longitudinal swellings, crossed by coarse spiral cords ( 4 on the penultimate whorl); the second one below the suture feebler than the rest; a much fainter interjacent thread in each interstice; about 15 cords on the last whorl, to the base of the canal, and some additional ones on its back. The interstices densely strigated longitudinally. Canal half-closed. Columella with 3 plications. Outer lip inwardly with 7 distant riblets and beneath them 3 narrower ones. Whorls 8 , height 15 , br. 5.3 , aperture $1.4 .5 \mathrm{~mm}$ without, and $7 \mathrm{~mm}$

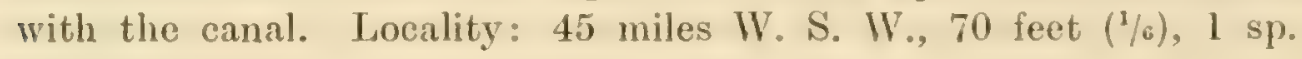

\section{FAM. BUCCINIDAE.}

Phos textilis A. Adass (Pl. 2, fig. 47). 45 miles W. S. W , 48 feet $(5 / 7)$; I sp., h. $17 \mathrm{~mm}$. The species is considered by Tryox (Man. of Conch., Vol. III, 1881, p. 216) to be identical with $P h$. senticosus Linné, but form, size, and sculpture, are very different. The present specimen agrees in these respects most closely with figures 48 and 49 in Sowerisy's 'Thesaurus Conch. 3, pl. 222, inasmuch as the whorls are inconspicuously convex, and the spiral sculpture consists of alternately stronger and feebler lirations; between an overlying feebler and an underlying stronger there appears a very faint thread, so that severy third one is prominent, as SowERBY describes the characteristic sculpture; further there exist fine longitudinal striae between the lirae. On the last whorl there are 9 longitudinal ribs or folds. The colour is quite white with a feeble trace of a subsutural series of dots. The mouth is white inwardly. Whorls about 9. As SowenBy's figure is very indistinct, the species is photographically reproduced here. It differs from $P$ 's senticosus in having denser and narrower lirae (about 7 in contrast to Ph. senticosus which has $4-5$ 
knobs) on the upper whorls, and in the absence of spinous nodules on them; even the longitudinal folds are considerably broader and rounded. - E. A. Sмiтir (1903) mentions this species from the Maldives and the Philippines.

Ph. senticosus Linne. 45 miles W. S. IV., 54 feet $(6 / 7)$, 1 shell, 1. $29 \mathrm{~mm}$. Distribution: Philippines (Tryor 1881), East Indian Archipelago (SchepMaN 1911); Queensland (Hedlex 1910); Victoria (Pritciard \& Gathiff 1897).

Tritonidea (= Cantharus) fumosa (Dillwys). 45 miles IV. S. W., 60-70 feet $\left({ }^{2-s} / \mathrm{r}\right), 2 \mathrm{sps}$, max. h. $45 \mathrm{~mm}$. The specimens are like ReEve's Buccinum proteus (Conch. Icon. 3, 1846, fig. 51 a), which Tryon 1881 (Man. of Conch., Vol. III) unites with Cantharus (-Tritonidea) fumosus. Distribution: Red Sea-Japan, Australia, Polynesia (Tryon 1881).

\section{FA. NASSIDAE}

Nassa livida Gray (= unicolorata Kiener). 45 miles W. S. IV., 66 feet, 3 sps, max. 1. $28.5 \mathrm{~mm} ; 54$ feet $\left({ }^{6} / 7\right), 1 \mathrm{sp} ., 1.26 \mathrm{~mm}$. Distribution: W., N. and E. coasts of Australia (Brazier 1886); Moluccas (Scinepman 1911, v. Martens 1903).

N. particeps Hedley. 45 miles W. S. W., 72 feet $\left({ }^{2} / \gamma\right), 1$ sp., 1. 20 mm. Like $N$. suluralis LAMARCK, but without sutural nodules; encircling red lines interrupted on the last half of the body whorl and accentuated in pairs, the median, upper, and lower ones being darker. The pairs are transversally connected by brown stripes and flames. REEvE's fig. 11 (Conch. Icon. 8) shows the closest agreement with the present specimen. HEDLEY (1915) discusses the synonyms and the distribution of the species. In 1917 he gives a figure and some ecological notices of it.

N. elegans KIENER. 42 miles W. S. W., 36-60 feet $\left({ }^{11 / 7),} 2\right.$ sps, max. h. 14 $\mathrm{mm}$. 'The colour is ivory white with some obscure longitudinal stripes, most obvious on the back, but without any revolving brown bands, which 'Irros (1882), gives as characteristics. 4-5 sharp striae encircle the base. TrYos gives so. Australia. as its habitat. Schepman (1911) records it from Makassar and Moluccas, V. MARTens (1S80) from Mauritius, MELrid \& STANDEN (1901, 1909) from the Persian Gulf to Andaman Isl.

\section{FAM. COLU MBELLIDAE.}

Columbella (Atilia) conspersa Gaskorn. 45 miles IV. S. W., 70 feet $(2 / 7), 1$ sp., h. $13.3 \mathrm{~mm}$, like the figure in 'Tryor (Man. of Conch., Vol. V, 1883, PI. 52, fig. 77 = fig. 99 in Revve, Conch. Icon., Vol. 11, 1858). - Distribution: Persian Gulf (Mervilu \& Standex 1901); Philippines, N. E. Australia, New Caledonia ('Irryon 1883).

C. (Meta) philippinarum Recluz. 45 miles W. S. W., 48 feet $(5 / 8), 1$ sp., 1. 17.3 mm; 66 feet $\left({ }^{16} / \mathrm{r}\right), 1 \mathrm{sp} ., 1.18 \mathrm{~mm}$. - Distribution: Andaman Islands, Philippines, N. Borneo (L. A. Surti 1901). 
C. (Conidea) discors Gmelin. 45 miles W. S. W., 60 feet $\left({ }^{13} / 1\right), 1$ sp., 1. 20.4 $\mathrm{mm}$. 'This species has a shorter spire and a longer aperture than the preceding one. At the aperture the last whorl is strongly ascending. It occurs from East Africa to the Philippines and New Guinea ('Tryos 1883, Schepran 1911).

C. (Mitrella) moleculina Duclos (P1. 2, figs. 48, 49). Shell ovate, pyramidal, with pointed apex and somewhat convex whorls, separated by shallow sutures welldefined below, smooth, except for faint lines of growth and some spiral lirations on the canal. Aperture about half the shell, outer lip crenelated within, and columella with 3 small tubercles. Colour whitish with a fine net-work of brown and a subsutural interrupted line of brown, with a white dot above each streak and larger ones alternating with the streaks; a similar marking of reversed position and alternating with the upper one is usually present above the periphery and the suture on the upper whorls; both series connected by square brown dots with produced and connected corners, with or without a series of brown meshes between the dots; at the base of the last whorl a series of small brown dots. Locality: 42 miles W. S. W., 66 feet $\left({ }^{11 / 7}\right), 1$ sp., h. $7 \mathrm{~mm}$; wh. $8 ; 45$ miles W. S. W., 66 feet $\left({ }^{15} / 7\right), 1$ sp., h. $8 \mathrm{~mm}$.

A rose variety (fig. 49) with only the subsutural series of markings and a single row of brown dots on the base of the last whorl occurred at 42 miles W. S. W., 66 feet $\left({ }^{11} / 7\right), 2 \mathrm{sps}$, max. h. 7.2, br. 3.2, aperture height $3.4 \mathrm{~mm}$.

The species moleculina is well defined by its subsutural series of brown streaks, running along the whorls, and the white dots combined with them; it is easily distinguished from the seemingly nearly allied $C$. lineolata PEASE by its narrow and pointed, not broadly obtuse, spire, and the mentioned characteristics of its colouration. The broken spiral line (also occurring in $C$. galaxias RELVE, Conch. Icon 11, 1859, fig. 220) is single in the typical $C$. moleculina Duclos which has, further, 4-5 columellar folds (cfr. Kobelt 1897, Die Columbelliden, Martini \& Cinematit, Conch. Cab., p. 315, Taf. 40, fig. 7, and Hervier, R. P. J., Le genre Columbella dans l'archipel de la Nonvelle-Calédonie, Journal de Conch., Vol. XLVIJ, No. 4, p. 330, 1899). T'o the present form evidently belongs $C$. moleculina of HEDLEY (1901) from Katow and Port Moresby, N. Guinea.

\section{FAY. CYPRAEIDAE.}

Cypraea cribraria Linné. 45 miles W. S. W., 80 feet $(2 \%), 1$ sp., 1. $24 \mathrm{~mm}$, br. 14, h. $11.5 \mathrm{~mm}$; only 14 feeble teeth on the inner wall of the aperture and 15 feeble teeth on the outer. A typical specimen of about the same size (1. 25.5 mm, br. $14.5, h .11 .5 \mathrm{~mm}$ ) has 21 teeth on the inner and 21 on the outer wall. Further, the present specimen differs from the type in having a brown primary colour and somewhat larger spots. It is similar to fig. 161, Pl. 311 (var. esontropia ReEve, not Duclos) in Sowerby, Thesaurus Conchyliorum, Vol. 4. - 'The species ranges from the Maldives and Ceylon to Mauritius and Funafuti, New Caledonia and New Ireland (E. A. Sinti 1903, Hedley 1899, Scineman 1909, 'Tryon 1885). 
C. lutea Gronovius. 45 miles W. S. W., 54 feet $(6 / 7), 1$ sp., $1.16 .5 \mathrm{~mm}$. It belongs to var. $\beta$ of REEVE (fig. $110 \mathrm{c}$, Conch. Icon. III) with 2 whitish bands. As to the colour of the animal was noted on the label: soft parts pretty light reddish tinted». REEVE does not state any locality for the species. TrYon (Man. of Conch., Vol. 7, 1885) gives it as occurring in N. Caledonia and Australia; Schepman (1909) records it from the Moluccas, Heder $(1910,1916)$ from Queensland and W. Australia.

C. subviridis ReEve. 42 miles W. S. W., $42-60$ feet $(5 / 7), 2$ sps, max. 1. 30 mm; 48 iniles W. S. W., 78 feet $\left({ }^{15} / 7\right)$, I sp., 1. $30 \mathrm{~mm}$. The shape and the colour agrees with those exhibited by figure 48 of REEvE (Conch. Icon, 3, 1845). - Distribution: Cambridge Gulf (Heder 1889), Queensland (HEDley 1910), New Caledonia (T'RYon 1885), W. Australia (Hedeey 1916).

Trivia grando Gaskorv (Pl. 2, fig. 50, 51; text fig. 11). 42 miles W. S. W., 66 feet $\left({ }^{11 / 7}\right), 1 \mathrm{sp} ., 1.8 .5 \mathrm{~mm}$. The specimen corresponds with the description and figures given by Roberts (Tryon, Manual of Conch., Vol. VII, p. 200, pl. 21, figs. $86,87)$, in the respect that the ribs are extremely fine and the spire is prominent, $i$. e. visible and feebly papilliform, projecting under the ribs. The shell is rose at both ends. The shape of the aperture seems to agree most nearly with the figures, as it is uniformly broad throughout and strongly flexuous (concave) only above at the spire, straight below (in contrast to $T$. australis LAMARCK, where it is flexuous below in the same degree as above). The interstices between the ribs are smooth above, on the under side feebly granulose. The dorsal furrow lies somewhat to the left and is curved to the left. - As typical specimens are not at my disposal and the determination is thus somewhat uncertain, I give a photograph of the specimen for identification. Distribution: Manila (TrYos 1885), Queensland (HEdery 1910).

T. oryza Lamarck (Pl. 2, figs. 52,53, text fig. 12). 45 miles W. S. IV., 66 feet $(16 / 7) 3 \mathrm{sps}$, max. $1.6 .5 \mathrm{~mm}$. The difference between this species and the preceding one is shown clearly from the figures given here compared with those of the former. The dorsal furrow in the present specimen is rather short (< half the shell). The distance of the under margin from the basal (anterior) end of the furrow is equal to the corresponding apical (posterior) distance and equal to about $1 / \mathrm{a}-2 / 5$ of the length of the furrow; the whole surface up to the furrow is rugous in the interstices of the ribs and the colour is pure white. - Distribution: Red Sea (T'RYoN 1885), Mauritius (v. Martens 1880), S. Africa (Bartscir 1915), Moluccas (Schepran 1909), Victoria (Pritciard \& (Athlfe 1899), Polynesia (Hedily 1899); Sandwich Isl. (Tryon).

T. bipunctata n. sp. (Pl. 2, figs. 54, 55; text fig. 10). Shell of the same shape as $T$. oryza, only somewhat narrower; colour light reddish, somewhat deeper towards the ends and round the base; on the inner (left) side of the dorsal furrow 2 reddish brown dots placed one behind the other. The dorsal furrow long (>1/2 the shell); the distance from its anterior (basal) end to the shell end is $1 / 2-2 / 3$ of the posterior upper corresponding distance and about $1 / 3-1 / 4$ of the length of the furrow. Sculpture consisting of strong radiating ribs with the interstices on the 
ander side and down the sides feebly rugated, dorsally smooth. The shape of the aperture as in $T$. oryza. 'The apical end of the shell somewhat produced. Spire not prominent nor visible.

Locality: 42 miles W. S. W., 66 feet $\left({ }^{11} / 7\right), 1$ sp., 1. 8, br. 5.4 , h. $4.5 \mathrm{~mm} ; 4$ ) miles W. S. W., 66 feet $\left({ }^{25} / 7\right), 1$ sp., 1. 7.5, br. $4.9,1.4 .3 \mathrm{~mm}$.

Even if the present form should prove to be identical with some species previously known, I prefer to describe it as a new one before trying to identify it according the diagnoses and figures accessible at present, which, through their incompleteness and through the accentuation of unessential characteristics without comparisons with other forms, rather make a determination uncertain than increase our knowledge of the forms in question.

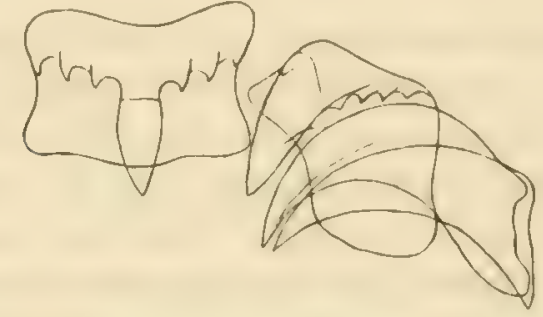

Fig. 10. Radula of Trivia bipunctala 11. sp. $\times 300$.

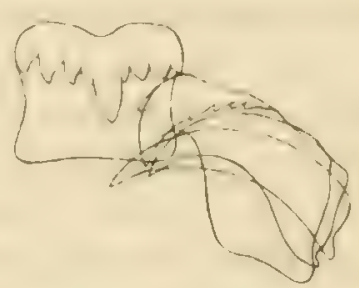

Fig. 11. Raduln of $T$. grando GASE. $\times 300$.

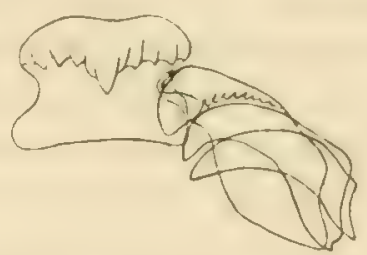

Fig. 12. Radula of $T$. oryza LAM. $\times 300$.

The radula of $T$ '. bipunctata (fig. 10) differs from that of $T$. grando (fig. 11) and $T$. oryza (fig. 12) in being comparatively broader; its median tooth has an elongated central spine and 3 denticles on each side of it; and the first lateral has 4 outer and 1 inner denticle. For comparison the radulae of the two other species, and even the specimens figured on plate 2, are reproduced here; they are narrower; have a smaller cusp of the central tooth and 4 denticles on its sides; the first lateral lias 1 inner and in 'T. grando 4, in 'T. oryza about 8 outer denticles.

\section{FAH. WITRIDAL}

Mitra variegata Rueve. 45 miles W. S. W., 66 feet $(\% / 2), 1$ dead shell, h. 23 mm. In form and colour most resembling $M$. nympha. REEve (fig. 249, Conch. Icon. 2, 1843), which is included by Tryos in the above species (Man. of Conch. IV, 1882, p. 113). - Distribution: Maldives, Mauritius (E. A. Surtu 1903); Quecnsland (HEDLEY 1910); Philippines (TrYoN 1882). 
Turricula (Pusia) festa ReEve (Pl. 2, fig. 56). 42 miles IV. S. W., 70 feet $\left({ }^{26} / 8\right)$, $1 \mathrm{sp} ., \mathrm{h} .11 \mathrm{~mm}$, br. 3.9 ; aperture $4.5 \mathrm{~mm}$; colour ash gray, brownish on the lower half of the last whorl, on the apex and above the sutures; columella with 4 folds. There are 17 longitudinal folds on a whorl and 6 spiral sulci on the penultimate whorl. As it is impossible to fix a single specimen withont material for comparison, I give a figure of the specimen in question. The sculpture and the colour is very similar to 11 . (Coslellaria) gotoensis E. A. Suntu 1879 (Proc. Zool. Soc., p. 215, fig. 51, pl. XX), but this latter is somewhat narrower than the present species. Distribution: the Philippines (Tryon 1882).

\section{FAII. MURICIDAE.}

Murex axicornis Lamarck. 45 miles W. S. IV., $60-72$ feet, 4 sps, max. 1. 59 $\mathrm{mm}$. Agrees in colour and sculpture with Pl. 16, fig. 161 and 163 in Tryon (Man. of Conch., Vol. 2, 1880). Distribution: Persian Gulf (Melvill \& STANden 1911), Ceylon, Andaman Isl. (E. A. Sirte 1904, 1906), S. Africa (BARtscil 1915), Ind. Archipelago (Schepmax 1911), Queensland (Heduey 1910).

M. cervicornis LamarcK. 45 miles W. S. W., $60-72$ feet, 2 sps, max 1. 58 mm. Distribution: Port Darwin (HedLEY 1889), Queensland (HEDLEY 1910), Aru Is1. (Schepuan 1911), W. Australia (Hedley 1916).

M. denudatus Perry (= palmiferus Sowerby). 45 miles W. S. W., 66-70 feet $\left(3 / 6,{ }^{20} / 8\right), 2 \mathrm{sps}, \max .1 .14 .5 \mathrm{~mm}$. For the nomenclature of this species see HEDLEY 1903. Distribution: Red Sea, all Australian coasts, New Caledonia (Brazier 1892).

M. brevispina Lamarck. 42 miles W. S. W., 42 feet $(5 / 7), 1$ shell, 1. $57 \mathrm{~mm}$. Distribution: Red Sea, S. Africa, N. Australia, Queensland ('T'RYoN 1880, Heduer 1910).

\section{FAII. CANCELLARIIDAR.}

Cancellaria septemcostata n. sp. (Pl. 2, fig. 57). Shell ovate ventricose with short spire and a wide and deep umbilicus. Whorls $5 \frac{3}{4}$, the apical $2 \frac{1}{2}$ rounded and smooth, the sequent ones planulated or slightly excarated and sharply angulated in their upper part, strongly plicated longitudinally, the costae 7 in a complete whorl, becoming more distant towards the aperture; ${ }^{1}$ umbilicus not costate within. Spiral lirae of alternating thickness, about 12 large ones in the last whorl with interjacent smaller ones. Besides this sculpture faint punctures arranged in somewhat irregular longitudinal rows. Aperture high triangular with 3-plicated columella and slightly rifled outer lip. Colour light yellowish brown, aperture of the same colour, white-lipped. Locality: 45 miles W. S. W., 66 feet $(9 / 7), 1$ sp., h. 10.5, br. 8 , l. of aperture $6 \mathrm{~mm}$.

In form this species approaches $C$. bicolor Hinds (REEve, Conch. Icon. 18, 187:3, fig. 29, and Lömbeke, Martini \& Chemnitz, Cancellavia, 1887, 'T'af. 22, fig. 34), but differs in its fewer costre and in the fine stippling all orer.

1 In the last whorl the costa behind the aperture has certainly been suppressed occasionally. 


\section{FAM. PURPURIDAE.}

Ricinula (Sistrum) ochrostoma Blarnville. 45 miles W. S. W., 70 feet $(1 / 6)$, $1 \mathrm{sp}$. , h. $15.6 \mathrm{~mm}$. With yellow dots in the crossing points of the longitudinal and the revolving costae; aperture white within. - Distribution: Persian coast of Indian Ocean (Melvill \& Standen 1901), Mauritius (v. Martens 1880), Queensland (HedLry 1910), the Philippines, Paumotus Isles (Tryon 1880).

\section{FAM. OLIVIDAE.}

Ancillaria monilifera Reeve. 45 miles W. S. W., 48 feet $(5 / 7), 1$ sp., h. 12.5 mm. Agrees in all essentials with ReEve's fig. 36 (Conch. Icon. 15, 1864) but between the series of points is simply white, not reticulated. REEVE's specimen comes from Swan River. TRYON classes the species with A. marginala LaMarck, which is, however, doubtful when we consider the difference in size.

Oliva duclosi ReEve. 45 miles W. S. W., $70-72$ feet $\left({ }^{1} / 6\right), 1 \mathrm{sp} ., 1.13 .5 \mathrm{~mm}$. It agrees best with Refeve's fig. $45 a$ of $C$. lentiginosa, which Truox (Man. of Conch., Vol. V, 1883) declares to be identical with the present species. It has elongated brown spots beneath the suture (5 on the whorl), 1 median and 1 suprafascicular band of spots (Tryon Pl. 32, fig. 17 is very similar). - Distribution: China to Australia, Polynesia and New Zealand (Trrov).

?0. sidelia Duclos (Pl. 2, fig. 58). 42 miles W. S. W., 36 feet $\left({ }^{11} / 7\right), 1$ sp., 1. $11.5 \mathrm{~mm}$; 45 miles W. S. W., $70-72$ feet $(11 / 6), 4 \mathrm{sps}, \max .1 .11 .5 \mathrm{~mm}$. The present specimens closely resemble O. faba Maryat (Sowerby, Thes. Conch. 4, pl. 343 , figs. 238, 239). TrYon considers this species as identical with $O$. sidelia. As the determination of the present specimens, in view of the great confusion of Olividae, is somewhat uncertain, I give a figure of the form here referred to $O$. sidelia. In colour it is light grayish blue with thin regular yellowish repeatedly angulated stripes and distant grayish brown twice-bent streaks and some large grayish brown spots beneath the suture ( 6 on the last whorl); interior white. The fine yellowish fulguration also recalls the more distinct colouring of $O$. rufofulgurata ScImPMaN (1911; Siboga Exp.). - Distribution: China to Viti Isl., and Madagasear ('Trron 1883).

\section{FAM. MARGINELLIDAE.}

Marginella (Volvaria) philippinarum livintidt, 45 miles W. S. IV., 70 feet $(2 / 7)$, I shell, l. $14 \mathrm{~mm}$. The shape is like that of fig. 84 in Reeve (Conch. Icon. 15, 1866), and the colour shows three very indistinct bands; the columella bears 4 plaits. - Philippines ('TrYon 1883), W. Australia (Hedley 1916).

M. (Volvaria) mustelina ANgaS. 45 miles W. S. W., 66 feet $(15 / 7)$, I sp., 1. 6 $\mathrm{mm}$. It agrees with the description and the figure in REEve (Conch. Icon. 15, 1866, pag. 48, pl. 12, fig. 87), as well as with the shape of fig. 82, pl. XXVI, in TATE \& MaY 1901 (Proc. Linn. Soc. N. S. Wales), the mouth is, however, somewhat more 
lengthened and the spire is shorter. 'I'RYon supposes that this species is synonymous with M. obscura REeve, a form confined to Aden (E. A. Snitir 1891, M. Suitir 1913 [in Nautilus]). I am of the same opinion, as the present specimen corresponds to the photograph given by M. Sintr, pl. IV, fig. 16, except that the bands are bordered by series of small dots. In shape the specimen before me is exactly intermediate between the figures given by TATE \& MAY and M. SMitr. - Distribution: Australia and Tasmania (Hedery 1908 b) to Aden.

\section{FAN. PLEUROTOMIDAE.}

Drillia sexradiata n. sp. (Pl. 2, fig. 59). Shell turreted claviform, whorls somewhat convex, separated by a shallow suture, margined by a subsutural cord. Aperture about $1 / 3$ of the height of the shell with broad and short recurved canal and a deep subsutural sinus, as well as a slight sinuosity behind the canal. Columella straight, with a slight callus at the body wall. Outer lip thickened, simple. Sculpture consisting of broad and strong, somewhat oblique, ribs, almost nodiform on the upper whorls, decurrent on the body whorl; they number 6 on the last whorl. Very fine spiral cords, alternating with finer ones over the whole shell, except for the 2 smooth apical whorls. Colour whitish, the interstices between the longitudinal folds as well as the columellar margin olive-brown, apex yellowish. Dimensions: H. 13, br. 4.4, aperture $5 \mathrm{~mm}$. Whorls 9 . Locality: 45 miles W. S. W., 48 feet $\left({ }^{16} / 7\right), 1 \mathrm{sp}$.

A total of 6 longitudinal costae is not common in the Pleurotomidae. It occurs in Pleurotoma hexagona Sowerby (Central America), Mangilia hexagonalis ReEvE (N. Australia), Pleuroloma albata E. A. Sirti (Persian Gulf), P. consociala E. A. Smiti (W. Africa), and sexcostata E. A. Sirtr, Singapore (Ann. Mag. Nat. Hist. ser. 5, Vol. 10, 1882), but none of them exhibit the longitudinal brown stripes which alternate with the broad costae.

D. varicosa Reeve (Pl. 2, fig. 60), 45 miles W. S. W., 70 feet $\left({ }^{2} / 8\right), 1$ sp. and 1 dead shell, $\max$. l. (sp.) 15.5, br. 4.7, aperture h. $6.2 \mathrm{~mm}$; whorls 10 . - The shape of both shells agrees with the figures given by ReEve (fig. $141 a, b$, Conch. Icon. 1, Pleurotoma, 1843), which it most nearly approaches also on account of its few varices scattered here and there, which are, however, less conspicuous than those described and figured by REEVE; the smaller specimen has them somewhat more distinct than the larger one. As REEVE's diagnosis is very brief, I give a new description of the specimens before me.

Shell produced, turreted, with somewhat convex whorls, sculptured with a subnodulous cord and a furrow below the sutures; and with dense and rather narrow, somewhat flexuous, longitudinal ribs to the number of about 17 , of which one is broader, round the last whorl, terminating in obsolete nodules at the subsutural groove and decurrent on the last whorl to the canal. Spiral sculpture consisting of impressed grooves, the interstices rising as rather coarse cords crossing the ribs; subsutural grooves smooth except for faint lines of growth. 'The two apical whorls 
wholly smooth. Aperture about $1 / 3$ of the height of the shell, with a broad and short recurved canal, a deep subsutural sinus and an obsolete sinus near the canal. Columella straight, with thin reflected margin and a small callus at the lip insertion on the body whorl. Outer lip rather thin, simple. Colour light violaceous, with a yellowish tint, the interstices of the ribs somewhat darker; apex bluish white. Distribution: the Philippines ('T'RYON 1884), Indian Arehipelago (ScHerMun 1913), Queensland (HEDLEY 1910).

D. hololeuca n. sp. (Pl. 2, fig. 61). Shell pyramidally claviform with rather convex whorls, separated by rather deep sutures bounded with a somewhat nodulous subsutural carina, and a furrow below it. Aperture somewhat shorter than $1 / 3$ of the shell height, with a broad and short recurved canal and a deep and narrow subsutural sinus, as well as a slight flexure in the lip margin above the canal. Columella straight, with reflected margin and some irregular rugae in the middle part; a thick callus spreading over the body wall at the lip insertion. Outer lip simple, somewhat slightly crenelated in its edge. Sculpture consisting of oblique and somewhat flexuous costae reaching the base of the eanal and about 17 in number on the last whorl, 13 on the penultimate one, crossed by elevated revolving lines to the number of about 24 on the body whorl, alternating with finer ones below its middle; in the subsutural furrow 1 or 2 spiral threads. The 3 apical whorls wholly smooth. Colour milky white all over. Locality: 45 miles W. S. W., 72 feet $\left(2 / z^{1}, 1\right.$ sp., 1. 17.2 , br. 6.1 ; aperture height $7.4 \mathrm{~mm}$, whorls 10 .

The shell somewhat recalls Pleuroloma torresiana E. A. Smitir (1884, Moll. of Alert Exped.) but has a thicker canal and oblique, uniformly sized, longitudinal folds, as well as a snowy colour.

Mangilia (Cythara) vittata Hxnds. (PI. 2, fig. 62). 45 miles IV. S. W., 72 feet $\left({ }^{2} / 7\right), 1 \mathrm{sp} ., \mathrm{h} .8$, br. 4.2 , aperture height $4 \mathrm{~mm}$. The specimen agrees in shape with fig. 65 in RiEVE (Conch. Icon. 3, 1846). 'The determination is, however, uncertain, as no useful characteristics are established by the authors on the rarious species belonging to this genus. I therefore give a photograph of the shell. It is entirely white, only the posterior part of the body whorl shows 3 very faint yellowish bands, the upper one in the subsutural furrow. The whorls are angled in the middle by the convexity of the ribs. The number of longitudinal ribs in the last whorl is 12 . 'They are crossed by very feeble elevated lines. Over the whole shell there exists a very fine, microscopical texture of granula, caused by the crossing of the spiral lines by fine longitudinal striae. 'Through the existence of this granulation, the suture becomes very feebly denticulated. - Distribution: Straits of Macassar (Trron 1884).

M. (Glyphostoma) spurca Hinns. 45 miles W. S. IV., 72 feet $(8 / 7), 1$ shell, h. $9.9 \mathrm{~mm}$. It has the characteristic form and sculpture as well as the three revolving brown bands on the last whorls, which RuErE mentions (Conch. Icon. 1, sp. 312). There are 11 longitudinal ribs on the last whorl, the last one raricose, and 5 
spiral cords on the penultimate whorl, of which 3 stronger, the subsutural zone is finely striated. - Distribution: N. Guinea, Straits of IIalacea, Australia (TrYos, Man. of Conch. 6, 1884).

M. crassicingulata Scripuan. 45 miles IV. S. W., 66 feet $(2 \% / 5)$, 1 empty shell, 1. $5 \mathrm{~mm}$; wh. 8. 'Though very small, the specimen exhibits in all details the characteristics of the very easily recognizable type (cf. Schemian 1913, pl. XXIX, fig. 1). It has 9 longitudinal ribs on the last whorl and 5 spiral cords besides 2 smaller subsutural ones above them. The produced shape is quite similar, and even the characteristic excavations in the interstices of the ribs on the basal constriction are traccable. The type specimen was taken in Madura Bay (Siboga Exp. St. 51).

\section{FAM. CONIDAE}

Conus pulchellus Swainson. 42 miles W. S. W., 72 feet, 1 sp., 1. $38 \mathrm{~mm}$, without pearly cords, only with elevated spiral lines at the base; no distinct spiral bands, only red lines and a rose tint at the angular lieel, marking a band; spire flamy of reddish brown and white. In shape it agrees with figs. 5 and 6 , in colour with figs. 7 and 8, pl. 36 in Weinkauff 1875 (Martini \& Chemnitz, Conch. Cab. Conidae). - Ceylon, Philippines, Mauritius, Australia, N. Caledonia (Melvilu 1909).

C. textile Linné. 45 miles W. S. W., 66 feet $(18 / 7), 1$. sp., $1.33 \mathrm{~mm} ; 42$ miles, IV. S. W., $66-72$ feet $\left({ }^{14} / \mathrm{r}\right), 2$ sps, max. 1. $30 \mathrm{~mm}$. Distribution: Gulf of Oman, Red Sea, East Africa, N. Australia, Philippines, Japan, Polynesia (Melvill \& StanDEN 1901, V. Martens 1880, 1903; Hedley 1889, 1910; Schepman 1913, Watson 1886).

\section{FAII.TEREBRIDAE.}

Terebra pertusa Born. 45 miles W. S. W., 65 feet $\left({ }^{9} / 7\right), 1$ sp., 1. $28 \mathrm{~mm}$. Agrees in the sculpture with a specimen of $T$. pertusa in R. M. (from Java), but the colour is lighter and the dots on the subsutural band are not so sharply pronounced. - The species is recorded from Darnley Island, Australia (Tryon 1885; Heduey 1910), S. Africa, Seychelles and Providence TsI. (II ELvilu 1909).

T. eximia DeshaYes (PI. 2, fig. 63). 45 miles W. S. W., 70 feet $(2 / 7), 3$ sps, max. h. $28 \mathrm{~mm}$, evidently not full-grown, as they have only 18 whorls. The sculpture agrees with the description and figure given by RELVE (Conch. Icon. 12, 1860, fig. 106). The colour is white, bluish and violet towards the apex, and dotted all over with a single series of obscure brown dots, situated either on the subsutural band or on the wholls. Besides the unique specimen figured by REEve, Melvile \& STANDEN (1S98) described and figured a second larger one $(48 \mathrm{~mm}$ ) from Madras (Journ. of Conch. 1898, pl. 1, fig. 8). Of the 3 present specimens found off Cape Jaubert, the largest one contains a far withdrawn animal, the others are empty.

T. columellaris Hinds. (PI. 2, fig. 64). 45 miles W. S. W., 70-72 feet $\left({ }^{2} / 7\right)$, 1. $22.8 \mathrm{~mm}$, whorls $15 ; 42$ miles W. S. W., 36 feet $\left({ }^{11} / 7\right), 1.17 .3 \mathrm{~mm}$, wh. 12. - On 
arecount of the produced shape of these specimens, I have determined them as belonging to this species (Soweriy, 'Thesaurus Conch. J, Pl. XLV, fig. 127, Pl. XLIV, fig. 77). Trrox (Manual of Conchology, Vol. 7, 1885) considers this species to be a variety of $T$. cancellala QUOY \& Garmard, but the definitions of the species within this genus are too uncertain for this opinion to be justified. The shell is grayish violet coloured, with a brown line somewhat below the sutural band, a light band in the periphery. The aperture is light grayish brown within, recalling $T$ ' livida REEve. The ribs are straight, distant, bent to the left; and there are a few distant striae (only 3-4, and on the lower half of the body whorl exclusively). - Distribution: Molucas, Philippines ('Tryon 1885, Schepman 1913), Queensland (Hedewy 1910), Maldives and Laccadives (E. A. Sumxi 1903).

T. textilis Hrnds. (Pl. 2, fig. 65). 45 miles W. S. W., $70-72$ feet $\left({ }^{2} / 7\right), 2 \mathrm{sps}$, max. 1. 20.5 mm. They agree completely with the figures in Sow Conch. I, Pl. XLIV, fig. 73), as well as with the description given by I. A. Surm 1879 (Proc. Zool. Soc, p. 185). Photographs of this and the preceding species are reproduced here to illustrate their characteristics, which are only indistintly to be seen in older figures. - Distribution: Japan, Straits of Macassar, Sandwich Islands ('Tryon 1885, Schepman 1913).

\section{Opisthobranchia.}

\section{Tectibranchia.}

Atys tortuosa A. Adums, 42 miles W. S. W., 66 feet $\left({ }^{11} / 7\right), 1$ sp., 1. $6.5 \mathrm{~mm}$. Though somewhat defective the specimen proves clearly to belong to this species as the aperture is produced above, as well as below, to form canals, especially inferiorly. Upper and lower ends of the shell are spirally striated and furnished with feeble, irregular, extremely fine, longitudinal folds, which end at the smooth (not spirally striated) median zone. The colour is a hyaline grayish white. - This species is mentioned by ReEve (Conch. Icon. 17, 1869, pl. III, fig. 15), from Philippines, by Brazier (1878) from Torres Strnit and New Guinea, 8-30 fms (Proc. Linn. Soc. N. S. Wales, Vol. II, Moll. of Chevert Exped.), and by Schepman (1913) from Sunda Islands, 36-90 m (Siboga Exped.).

\section{Nudibranchia.}

Ceratosoma corallinum n. sp. (Pl. 2, figs 66, 67; text fig. 13). Animal rather slender, with a far produced tail and a high body, sloping sharply towards the front. Dorsal surface quite flattened and smooth, sharply limited all round at the sides by a well defined margin. One pair of well developed, rounded lobes, thinning towards the edge, just behind the middle of the back. Posterior protuberance narrow $\left({ }^{1} / 4\right.$ of the back across the lobes) and short (about $1 / 4$ of the length of the back in front of it), distinctly set off, and broadly canaliculated beneath. Head separated from the 
back by a slight constriction, and furnished with a sharply projecting margin, forming two side lobes, separated by a slight front concavity. Colour a marbling of light rose and yellowish white, forming large spots or clouds. On the back, the red tint occupies 3 zones: the head, the middle part, and the hind part (in the latter the lobes on their median portion), separated by whitish transverse bands. The posterior projection on its upper side, expecially behind, dotted with some darker red points; such a marking indistinctly appearing also on its under side. Sides of body red-marbled above, uniformly whitish below, tail somewhat more vividly red with yellow whitish spots and 3 transverse bands of the same colour.

Gills about 16, surrounding the anus on the sides and in front, bush-like, trifid, strongly expanded, with red ends and white roots. Rhinophorial pores with slightly elevated yellowish white margins, rhinophorial clubs rose tinted, closely laminated.

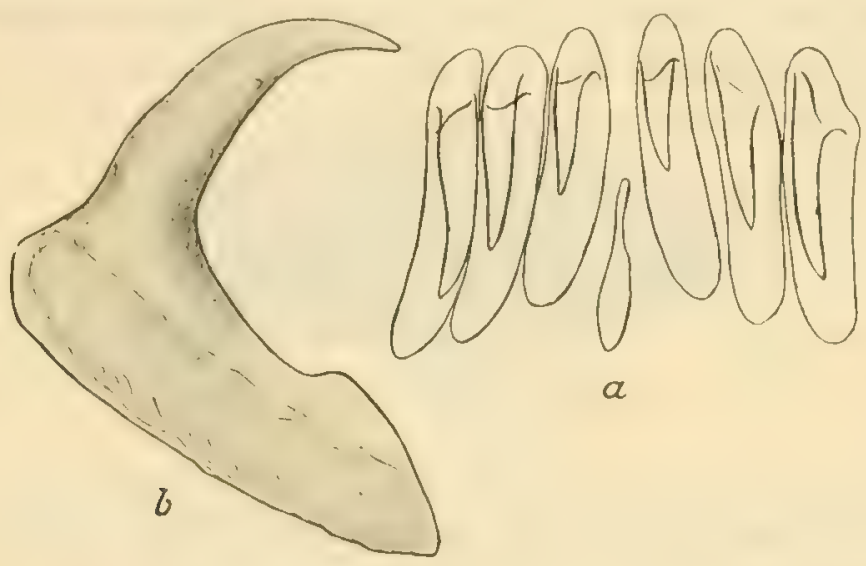

Fig. 13. Radula of Ceralosoma corallinum n. sp. a rachis, with rudimentary median tooth, $b$ lateral tooth from outside.

Dimensions in millimetres: Length of animal 78, 1. of body portion 44, 1. of tail 34 , h. of the tail at the root 10.5 , breadth 8 , height of body at the gills 20 , breadth of body across the lobes 17 , l. of hind process 9 , br. at the base 6 , br. of head 13.

Radula (fig. 13) $\infty .1$. $\infty$. The teeth agree with those of $C$.cornigerum (ADAMS) BerGH, gracillimum (SEMPER) BERGH and trilobatum (GRAY) RochemRUNE, described and figured by BERGH in 1876, but differ from those of $C$. polyomma BERGI 1880 and $C$. bicorne BERGH 1905, where more $(3-6)$ denticles are present. Median tooth is rudimentary, and without hook, lateral teeth are very close with a sharp underedge and a strongly curved hook; a very small denticle on its outer side.

Locality: Cape Jaubert, 45 miles W. S. W., 72 feet ( $/ 7$ 1911).

The present form approaches in shape and colour C. lixi RocIEBRUNE (1895, pl. 6, fig. 61), from Dead Island, Torres Strait, but the latter has numerous small red dots scattered over the uniformly rose-tinted body and a blue marginal line. Further it differs in having a narrower tail, a concave front margin of the head, and stronger side-lobes. As a consequence of these differences, I consider it a distinct 
species. Also in its manner of life, $C$. lixi differs from the present form in its occurrence on algae and clay bottoms (cf. Rochebrune 1. c., p. 138). - 'The most recent publication on the genus Ceratosoma is the monograph published by RocukBRUNE (1895). In his valuable work he gives some figures in colours of all the species occurring preserved in the Paris museum, and he there gives diagnoses of the 14 forms known then. Since 1895. BERGin (in 1905) has described and figured a new characteristic species, C. bicome, from Sapel Strait, Java Sea. Further (in 1905) BASEnOW and HEDLEY described and figured from York Peninsula a $C$. adelaide, 8 $\mathrm{mm}$ in length and $3 \mathrm{~mm}$ in breadth. This form, as well as that described and figured by the same authors as $C$. brevicaudalum AisanAu, seems to belong to the genus Chromodoris, ALDER \& HANCOCK 1855 (= Hypselodoris STIMPSON 1855).

Doridopsis guttata 11. sp. (PI. 2, fig. 71). Body elongated elliptic, entirely smooth, rather convex, with a narrow, slightly undulating, perinotum or mantle border all round, of a bright brick-colour with distant black spots irregularly scattered all over, the largest ones in the median part, smaller ones in the margins.

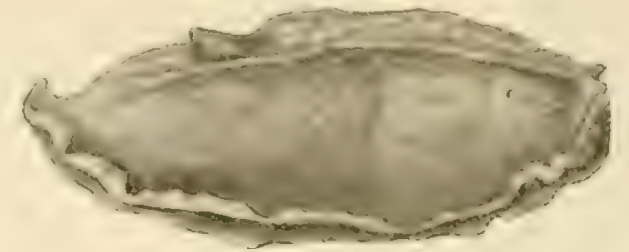

Fig. 14. Trevelyana marginata $\mathrm{n}$. sp. Viewed from tho right. $\times 4.5$.

Gills situated far back (at $1 / 9$ of the body length from the rear end, consisting of 6 tripinnate plumes with their axes black towards the ends. Rhinophores with paucifoliate clubs; their lower half white, the upper one black with a white stripe on the tip. Rhinophorial and branchial openings with smooth margins. Anal tube projecting in the middle line of the branchial circle, on its hind periphery, symmetrically flanked by the branchial plumes. Under side of the notum smooth, somewhat lighter than the dorsal surface, and withont dots, except for some in the margins. Foot broad, equal in length to the notum, rounded in front. Oral tentacles forming a sort of oral veil, narrowly expanded at the sides of the oral pore. Dimensions: Length 8 , breadth 4 , height $3 \mathrm{~mm}$. Locality: 45 miles $W$. S. W., 72 feet $(2 / 7), 2$ sps. Up to the present no classification of the comprehensive genus Doridopsis has been attempted, for which reason there are great difficulties in identifying the species belonging to this genus. ELIOT (1906) includes in it 66 species, to which BERGH (1907) has added 3, and VAYssik̀ne (1912) also 3 new ones. In the literature accessible to me I have met with no form similar to the present one, which presents a very characteristic colour, constant in both the specimens taken.

Trevelyana marginata n. sp. (figs. 14, 15). Body limaciform, somewhat compressed from the sides, highest in the middle, slightly and convexly sloping towards the ends. Back rounded (from side to side), somewhat pustulate and rugose, divided from the sides of the body by a low list ruming forwards and joining the 
mouth disc in front of the rhinophores, which are situated far in front and close to each other, their clubs consisting of about 12 foliations emerging from a fronta] rhachis. Rhinophorial openings with a simple margin; in front of them an indistinct papilla forming the starting-point of the marginal line; this stretching backwards behind the gills and terminating in a somewhat papillous thickening without joining that of the opposite side. Gills situated at the beginning of the last third of the body, forming a bow in front of the anal opening, consisting of 13-14 leaf-shaped lamellae, with their axial edge turned forwards, each lamella bearing on both sides small rami. Foot narrow with somewhat expanded, thinning margins, rounded in front and connected with the oral disc. No oral tentacles. Penis long and narrow, armed with a few series of small hooks.

Colour (in alcohol) uniformly whitish with a darker bluish tinge shining through from the peritoneum. Length of animal $13 \mathrm{~mm}$.

Locality: Cape Jaubert, 45 miles W. S. W., 54 feet $(6 / 81911), 1$ specimen.

Radula small, with about 15 rows of teeth of about 13 teeth on each side. Rhachis unarmed. The inner teeth of the same hook-shaped form as the others (fig. 15).

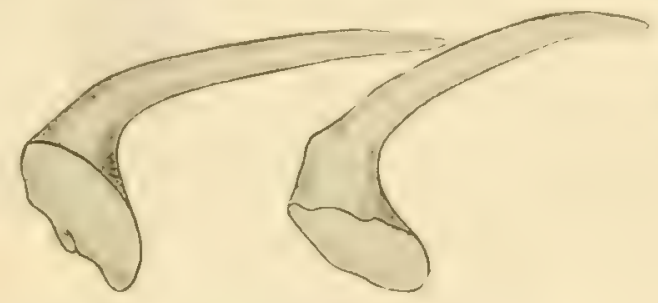

Fig. 15. Trevelyana marginata n. sp. To the left one of the inner, to the right one of the outer lateral teetl. $\times 235$.

In the narrow but distinct margin of the back and in the uniform shape of the radular teeth, this species differs from all previously known species of the genus. ${ }^{1}$ It therefore comnects the genus Trevelyana with that section of the family Polyceridae in which all the teeth are uniform in shape, comprising the three genera Notodoris, Triopella, and Acgires.

Madrella ferruginosa ALDER \& HANcock (Pl. 2, figs. 68-70; text figs. 1623). 45 miles $\mathrm{W}$. S. W., 72 feet $(2 / \%), 1 \mathrm{sp} ., 1.12 .5 \mathrm{~mm}$; breadth of the mantle $5.5 \mathrm{~mm}$, breadth of the foot $5.3 \mathrm{~mm}$. Colour of whole animal rusty brown, the papillae somewhat lighter than the rhinophores and the rest of the body.

Only a few notes about this interesting nudibranch have been published. It has been recorded from Zanzibar (many specimens, ELiot 1902, 1903), from the Maldives (ELtot 1903, 1 sp.) and from the Indian Ocean (AldER \& HANCOCK 1S64).2 ELIot (1902 and 1903) has made some observations of the living animal and its I.nnilon)

1 For these see Litor 1906 (On the Nudibranchs of Southern India and Ceylon etc, Iroc. \%ool. Soc.

- Tamus sanguineus of Asous (Journ. de Conch. 1864) may perhaps be identical with the present species, though the median part of the back lacks the papillac. It is reconded from Watson Bay, Sydney. 
habits. He remarks the resemblance of this form to Tritonia and considers it a connecting link between the Janidae and the other Aeolididae. As his account of its morphology is very short, a more complete description may be given here, based on the present specimen, which was examined both in toto and in sections.

As to its exterior shape, the dorsal side is occupied by a large notaeum, which surrounds and extends beyond the foot and the head. Near the hinder end of the body, this notaeum passes directly into the foot, its margins on both sides being connected with the foot end. The margins of the notaeum are set with papillac all round, these are smaller at the edges and become larger towards the centre; in the middle part of the back they are replaced by minute papillae; such also occur be-
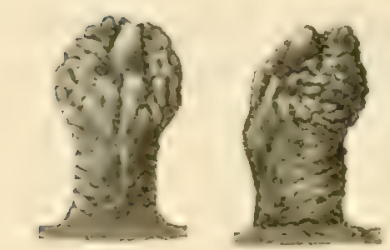

Fig, 16. Rhinophore of Madrella ferruginosa A. \& H. from front and from side.

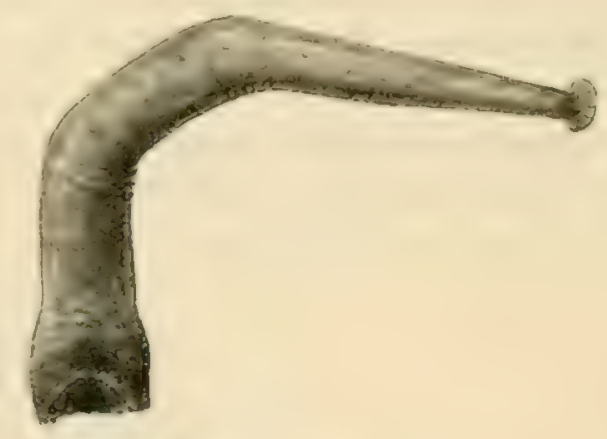

Fig. 17. Jorsal papilla of Madrella ferruginosa A. \& $\mathrm{H}$.

tween the rhinophores, without, however, forming any feature that might be regarded as a rudimentary crest, such as ELIOT has observed in large specimens. The under surface of the notaeum is quite smooth.

The rhinophores (fig. 16) somewhat resemble those of a Tritonia, as ELiot remarks. A short peduncle bears a club divided into leaf-like lobes or tubercles, arranged round a subcentral tip, projecting beyond the tubercles. In the front side the peduncle carries an obscure furrow running from top to base. On its hinder side the peduncle is wrinkled by some semicircular lamellae, which disappear on its front side; these may perhaps be due to contraction. The rhinophores are not retractile and have no sheaths.

At the base of the rhinophores, on their inner side, a small eye is visible, by its pigment shining through the epidermis (fig. $21 \mathrm{o}$ ).

The anterior corners of the foot are angular and only slightly projecting. 'They are free from the velar expansion around the mouth. This velum is semicircular and produced on each side into a rounded lobe. Towards the median line, the lobes are attached to the front margin of the foot. The velum projects quite freely from the neck and is free from the notaeum.

On the right side of the body are visible the genital opening in the first third and the anal orifice in the last third of the body length. The renal pore is situated between these two, somewhat nearer to the anus. 


\section{Anatomy of Madrella ferruginosa.}

A microscopical examination of sections through the notaeum gives some interesting results. Not only are the cerata empty, as ELIOT (1913) states, and contain no liver diverticula nor any apical cnidocysts, but on the contrary these latter are included in cnidosacs situated at the bases of the cerata. Even by macroscopic examination one can perceive the openings of these cnidosacs at the tops of some small swellings at the side of the cerata (Pl. 2, fig. 68; text fig. 17). These small enidophorous sacs are combined with the liver diverticula by small canals. They are lined inwardly (fig. 18) with the characteristic cnidoblasts which are described by, for example, Herdian 1890 and Hecht $1895(\Rightarrow$ nématophages', СUе́мот 1907) and which are considered to be ectodermic cells by the first-named author and modified cells of the liver coecum by later scientists.

That the latter opinion is the correct one is proved by the conditions prevailing in Madrella (fig. 18). The cnidophorous sac not only communicates with the liver coeca, but the cells of the former gradually pass into those of the latter by means of the connecting collar cells. In this portion the cells

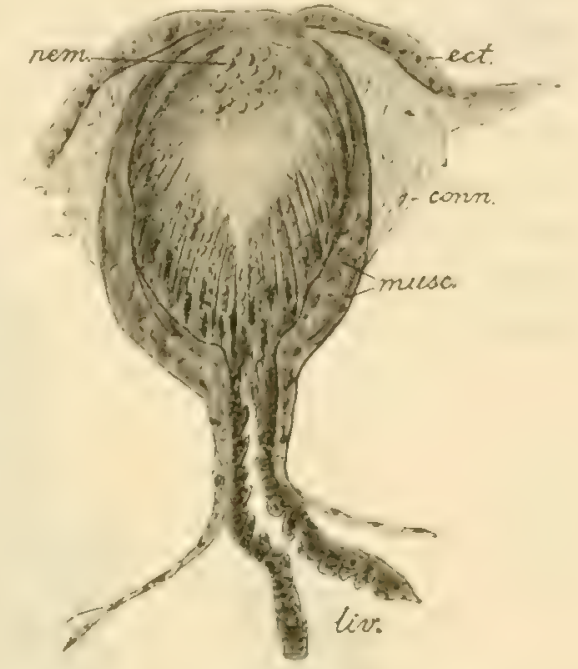

Fig. 18. Section through a cridosac oMadrella ferruginosa A. \& H. conn. connec; tive tissue; cet. atoderm; liv. liver collnf musc. unicullular museled; urm. nematoryts. are shorter than the cnidoblasts described below, but in other respects they are similar to them; they also contain brown granulations, like the cnidoblasts on the one hand and like the liver cells on the other, thus giving support for the supposition not only that the cnidoblasts are modified liver cells, but that their granula are homologous with those of the last-named.

The cnidoblasts are long cylindrical cells with nearly basal oblong or pyriform nucleus. Above the nucleus they are filled with rounded, brownish granulations, which seem to be active by the arrangement of the cnidocysts in the cnidoblasts. They are to be found only in the innermost cnidoblasts and here only in their basal half, while the apical half is occupied by small ovoid vacuols enclosing the cnidoblasts. The undermost of them are set with some small granula, but whether the cnidoblasts are formed or only arranged by means of these granula, could not be made out from the present material.

The cnidophorous sac is surrounded with walls formed by unicellular muscles (fig. 14, musc.); the walls are thickest towards the base of the sac and grow thinner towards its apex. The muscle cells, which cross each other irregularly, extend down the collar and later on pass into the fibrillar cells which surround the liver diverticula. Fven towards the apices of the cnidophorous sacs, the muscular cells pass into fibrillar ones, which are expanded beneath the epithelium. 
Near the pore of the enidophorous sac, this latter is filled with secretion, in which appear many cnidocysts $(n \mathrm{~cm}$.); these are very small, being only about $3-5, \mu$, and ovoid in shape.

In the morphology of the cnidophorous apparatus, Madrella represents a primitive stage in comparison with other Eolids, not only in the position of the saes on the notaeum at the base of the papillae, but also in their structure, which is not so specialized as in Acolididae. The collar is very short, with a transgredient epithelium which is not ciliated (as in Acolis papillosa e.g.). 'The muscular layer of the cnidophorous sac shows a primitive stage inasmuch as it is not yet differentiated into a longitudinal and a circular stratum (as in Ae. papillosa) and as it very clearly passes into the fibrillar covering of the hepatic coeca, thus showing its origin from the connective tissue. Madrella, as a consequence, shows the way of development of the cnidophorous sacs of the Aeolididae.

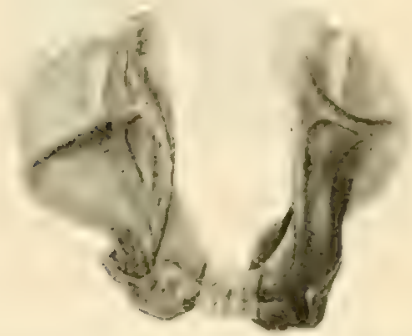

Fig. 19. Jaws of Malrella fermginosa A. \& II., from above.

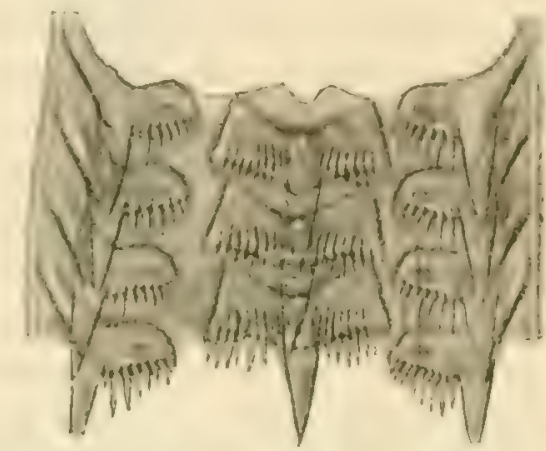

Fig. 20. Iaclula of Madrella ferruginosa A. \& II.

The papillae of the notaeum (fig. 17) are simple prolongations out of the connective tissue that fills their interior; they have no hepatic diverticula, but are furnished with a cnidophorous sac within their root. 'Their apices are expanded like a pins head, as shown in the figure.

Interior anatomy. Concerning, first, the alimentary canal, we find that the bulbus pharyngeus is of considerable size.

The jaws (fig. 19) are two chitinous lateral plates of a yellowish horn colour, combined in front on their upper side by a bridge of a cartilagineous consistency and of white colour. 'This unpaired section has a thicker anterior margin, with some rifle-like stripes of a firmer consisteney, but not forming prominences on the surface. Its hinder part is lamelliform and tapers towards its posterior margin.

The lateral parts of the jaws have an elongated wing-form. Their foremost lower ends, at the sides of the connecting bridge, are swollen and rounded and with no trace of denticulation. They each bear on their under part a small projection of the same swollen habitus, representing a rudimentary masticatory process. The dilated posterior parts of the jaws are furnished, on the outer as well as on the inner walls, with crests running one in a longitudinal, the other in a transversal 
direction; on these the muscles of the pharyngeal bulbus are inserted. No denticulation at all exists on the jaws, which have a homogenous lamellar structure with thickenings at the ridges.

The radula (fig. 20) has the formula $45 \times 1.1 .1$; it measures $0.5 \mathrm{~mm}$ in breadth. The breadth of the median tooth is $0.18 \mathrm{~mm}$, its length is $0.09 \mathrm{~mm}$, the lateral tooth has a breadth of 0.14 and a length of $0.11 \mathrm{~mm}$. All the teeth are of a light yellowish colour. They consist of a strong central spine and lateral denticles, in the median tooth at both sides of the spine, in the lateral ones at the median side only. The number of denticles is somewhat variable: $7-10$ in the lateral teeth and $9-11$ on

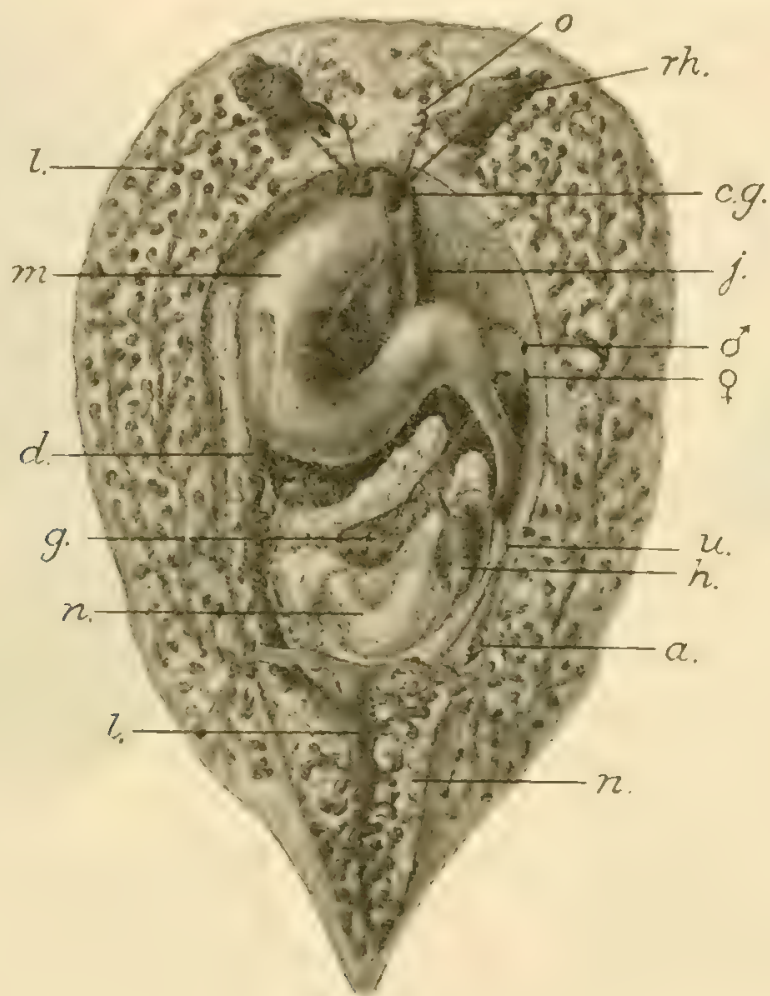

Fig. 21. Anatomy of Madrella terruginosa A. \& H a anus. c. g. cerebral ganglia: $d$. liver duct; $g$. hermaphrodite gland: $h$. hoart; $j$. pharyngeal bulbus; $l$. liver diverticula; $m$, stomach: $n$ nephridium; o eyes; $s h$. rhinophores; $u$. nephridial pore; ot male, of female genital orifico.

each side of the median ones. In each tooth the denticulated part forms a semicircular areh or comb, the innermost pines in it being the longer ones in the central teeth, and the most lateral ones in the lateral teeth. Seen from behind, each tooth has a somewhat shield-like, slightly convex, upper surface.

Behind the pharynx a short and narrow oesophagus leads to the stomach, which has a somewhat curved shape (fig. $21 \mathrm{~m}$.) and lies towards the left. From the stomach the intestine emerges and runs over to the right side, then over the mueus gland and the hermaphrodite gland again over to the left side, from where the rectum bends back again and leads in a slight curve to the anus (a.). The intestine is, 
thus, of a more considerable length in the present species than in most of the Acolididae, and it is, and more so the stomach, wider than the liver duct (see below). The intestine has no internal fold such as is described in the case of Aeolis by HЕснт (1895), but only a number of plications of its walls throughout.

On the under side of the stomach, in the middle of its length, debouches a narrow, very long, liver duct $\left(d_{\text {. }}\right)$, which leads from the posterior part of the body behind the rectum, where it springs from the principal liver trunk. This stretches

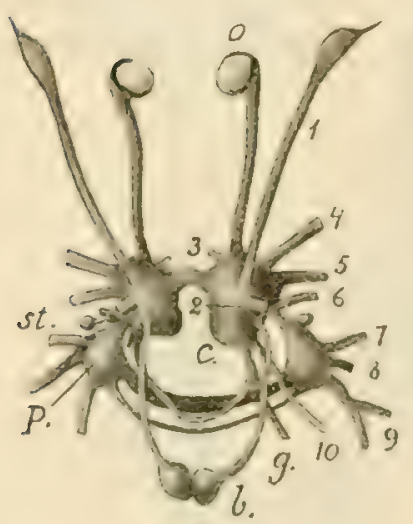

Fir. 22. Nervous system of Madrella ferruginosa A. \& II. b. buccal ganglia; c. cerebro-pleural ganglia: g. genital norve; o oyes; p. pedal ganglin; 8 . statocyst; 1 rhinophorinl nerve with ganglion olfactorium: 2 nervo to the tegument of tho head: 3 small nerves to the upper part of the oral veil; 1 nerves to the lateral parts of tho oral veil; 5 circumbuccal nerve; 6 anterior lateral nerve: 7 latero-pallial nerve; 8 anterior pedal nerve; 2 posterior pedal nerve; 10 pallio-dorsal nerve.

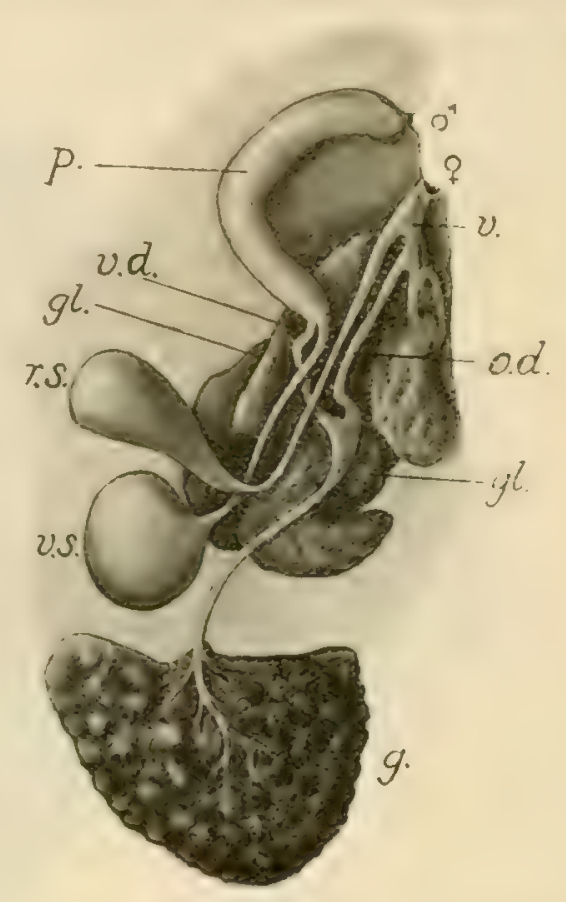

Fig. 23. Genital system of Madrella ferruginosa A. \& If. g. hermaphrodito gland; gl. nucus glaud; o. d. oviduct; $p$. penis shenth; r. s. receptaculum seminis; $v$. vagina: v. d. vas doferons; v. s. vesicula seminalis; or male, of femalo genital urifice.

backwards in the median line, with numerous branches, and from its anterior end there emerges one lateral trunk on each side, proceding forwards and branching into the anterior and lateral portions of the notaeum. This liver system $\left(l_{\text {. }}\right)$ differs considerably from that of the whole group of Aeolidioidea (LLIOT 1910), even from those forms belonging to it which have the liver diverticula partly retained in the body, partly in the cerata (Janidae). In Madrella ferruginosa the liver is entirely enclosed in the body and sends no branches into the cerata. ${ }^{1}$ Further the liver is, as a whole, trilobed, and debouches into the stomach by means of a single duct (d.). This last-named condition separates Madrella from as well the Aeolidioidea as the family Pleurophyllidiidae, where three liver ducts (one median and 2 lateral) debouch

1 Eriot (1902) states that very short diverticula of the liver penetrate into the cerata: in 1903 he finds them empty. 
into the stomach, and make it more closely related to the group Dendronotoidea (ELIOT 1910), in which the liver is normally three-lobed.

The nervous system (fig. 22) does not present any peculiarities; it seems to be of the same type as in the tribe Aeolidioidea, with some exceptions from the rule. Thus the ophtalmic nerves are rather long, and the ganglia olfactoria are situated within the peduncles of the rhinophores, from where they send nerve branches to the tubercles of the club.

The kidney $(n$.$) occupies a great part of the body, but has not such numerous$ branches as in Aeolidia (cf. Hecrit). It consists chiefly of a median, widened sac and lateral branches from it, passing forward on each side. The reno-pericardial tube is very wide, with the usual strongly folded walls. It opens to the right of the pericardium.

The latter, as well as the heart $\left(h_{0}\right)$, is situated on the right side of the body.

The genital organs (fig. 23). The hermaphrodite gland $(g$.) occupies the space between the stomach and the rectum; thus it is of comparatively small extension. The eggs are formed in the same folliculi as the spermatids, in their tops; the spermatids have long and narrow heads. - From the hermaphrodite gland runs a wide canal, in the present specimen filled with spermatids, which proves that these are mature before the ova; this hermaphrodite duct bifurcates into a male vas deferens $\left(v, d_{0}\right)$ and a female oviduct $\left(o_{0} d_{0}\right)$. The former leads to the penis $\left(p_{0}\right)$ and receives immediately, before its junction with the penis sac, a duct from a large spermatocyst (or vesicula seminalis, v.s.). The female oviduct is short and debouches into the vagina $(v$.$) ; here also opens a duct from a spermatocyst (receptaculum semi-$ nis, $\left.r s_{*}\right)$ as well as the outlet from the mucus gland $(g l$.) and the connected albumen gland. The penis opens somewhat in front of and below the female orifice.

The whole apparatus is thus rather simply constructed and presents the diaulic type (in the sense of ELIOT), because the hermaphrodite duct furcates into two, not three canals.

The presence of a vesicula seminalis in the male apparatus is a characteristic that distinguishes Madrella from the Aeolidioidea and gives it a resemblance to Tritoniidae. In Marionia blainvillea as well as in Tethys fimbriata, VAYSSIÈre (1901) has described a similar appendix to the male apparatus, which he names prostata; this is situated just beneath the proximal end of the vas deferens. This prostata also exists in Pleurobranchidae, in the Holohepatica, in Ascoglossa, and in the Dendronotoidea (ELIOT), but is absent in Aeolidiidae, Pleurophylliidae and allies. The vesicula seminalis present in Madrella seems to be a homologon to this prostata gland or a further development of it.

General remarks on the genus Madrella. Besides the present type the genus contains another species, M. aurantiaca, established by VAYSSIÈRE (1903) from the Gulf of Marseilles. A description of its anatomy is given, from which it appears that the cerata contain liver diverticula, but have no nematocysts and do not present any knoblike dilations of their tips. The rhinophores, the jaws, and the teeth of the radula are very like those of $M$. ferruginosa. As ELIOT states about the latter species from 
Zanzibar that into each of the cerata passes a very short diverticulum of the liver, it seems as if the extension of the liver into the cerata is subject to variation within the genus. $M$. aurantiaca seems to differ from $M$. fermiginosa also in possessing a naked median portion of the back, the marginal zones only bearing cerata, as well as in the shape of the jaws, which are not combined as in $M$. fermginosa, but separated, and lack the transversal crest present in this species (cf. VAYsSIÈ E 1903, pl. III, figs. 29, 30).

In 1909, VAYSSIÈRE, for good reasons, established for Mndrella and the new genus Eliotia a separate family, Madrellidae, the characteristies of which he gives in these words (l. c. p. 637):

'l'entacules dorsaux ou rhinophores cylindro-coniques, présentant autour de leur moitié supérieure de nombreuses digitations tubulaires, simples, contractiles, rappellant un peu celles des rhinophores des 'I'ritoniadés.

Les mâchoires de ces Mollusques, au lieu d'être lamelleuses dans toute leur ítendue, comme chez les Aeolididés, sont massives, très épaisses, cornées, mais assez molles, à face interne peu concave et à face externe irrégulièrement convexe, mamelonnée avec ou sans arêtes longitudinales.

\section{c. Cephalopoda.}

Octopus membranaceus Quor \& Gamard. 42 miles W. S. W., 42 feet $(5 / 7)$, 1 sp., I. $42 \mathrm{~mm}$ (of which the body $17 \mathrm{~mm}$ ). 'This species is easily recognized by the presence of an ocular spot between the base of the second and third pairs of arms. Distribution: Japan, China, New Guinea ('Tryow 1879).

O. cuvieri d'Orbigny (= macropus Risso). 45 miles W. S. W., 72 feet $(2 / 7)$, $1 \mathrm{sp} ., 1.50 \mathrm{~mm}$ (thereof $15 \mathrm{~mm}$ for the body). - Distribution: Canaries, Mediterranean, Red Sea, Indian and Pacific Oceans ('l'ryon 1879).

\section{d. Amphineura.}

Craspedochiton laqueatus SowerBY. 42 miles W. S. W., 70 feet $(26 / 51911)$, 7 sps, max. 1. 27.5, br. $18 \mathrm{~mm} ; 45$ miles W. S. W., $50-80$ feet $\left({ }^{29} /,{ }^{16 / 7} 1911\right), 10 \mathrm{sps}$.

The genus Craspedochiton SHutreworti (1853) includes the following species: C. laqueatus (Sowerby 1841), Philippines, C. liberiensis (Tnmet 1909), Liberia, $C$. ('Thaumastochiton) möbiusi ('I'Hele 1909), Mauritius, C. (Angasia) tetricus Carpexter, Red Sea. The present specimens from Cape Jaubert approach in all essentials the Philippinian form, but differ from it in some details in the shape of the ralves. These are - especially the anterior one - somewhat more depressed, and have a more quadrangular circuit than the figure in PILSBRY (1893) indicates, in the fact that the sutural plates are more dilated and have a convex, well curved outline. Also the 
posterior valve has a greater length, in relation to its breadth, than the figures show, its sutural plates are not produced so far laterally but are more dilated forwards and evenly rounded.

The colour of the present species is very variable from grayish to brownish, usually marbled in red and green and maculated with white. In one specimen the girdle is light green with red dots on the margin and a couple of darker green blotches at each end, in other specimens it is light reddish brown with purple stripes or flesh-coloured, minutely dotted with dark brown. Other specimens have the girdle grayish, minutely punctated with brown and maculated with green elouds. 'The valves, too, are variegated of gray, green, white, and reddish, forming stripes, points, or blotches, in various patterns. Inside, the valves are rose-tinted or white. The girdle is of a leathery consistency and bears a fringe of very short spicules on its elge, its under-side is yellowish white, dotted and clouded with brown, especially at the fore end, where it is broader. The gills attain only half the length of the foot.

The species was first recorded from the Philippines, 9 fms (PILsBry 1893), and has afterwards been found in Ceylon, $5-13 \mathrm{fms}$, in the Maledives and Laccadives, $1-33$ fms (E. Surti 1903, including $C$. letricus), and in the Zanzibar Channel, 5-20 fms (SYKES 1907).

\section{Mollusea from the shores of Queensland.}

Placuna placenta Linné. Cairns, in mud on the shore, 1 sh., max. diam. (breadth) $115 \mathrm{~mm}$.

Chione peronii Lamarck. Yarrabah (May 1913), 5 sps, max. 1. $32 \mathrm{~mm}$.

Natica (Mamma) plumbea Lıмırck. Yarrabah (May 1913), l sp., h. 34 mm. 


\section{B. Land and fresh-water Mollusca.}

\section{From West-Australia.}

FAM. ENDODONTIDAE.

Endodonta (Charopa) tumida n. sp. (Pl. 3, figs. 72-74; text figs. 24, 25). Shell inflated discoidal, flattened or slightly concave above, deeply and openly umbilicated below, the umbilicus in diameter equalling half the last whorl. Whorls tumid,

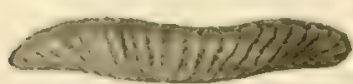

Fig. 24. Jaw of Endodonta tumida n. sp.
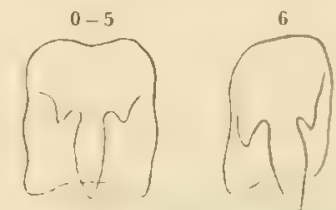

Fig. 25. Teeth from the radula of $E$. tumida n. sp. $\times 1000$.

well rounded, sculptured by dense transverse thread-formed costellae. Last whorl not descending in front. Aperture reniform, nearly vertical, with simple lip of slight sigmoidal curvature. Colour light reddish brown. Whorls $3^{1 / 2}$. Diameter 3.9, height 2 mm. Locality: Noonkanbah, Fitzroy River, at the Pandanus Spring, 10\% 1911, 8 sps.

The flattened or concave apex and the relatively small umbilicus, as well as the size of the shell, distinguishes this species from any known West Australian Endodonta (cf. SMitit 1894, HedLey 1895).

The animal lacks a caudal mucus pore; it has a radially grooved jaw (fig. 24) and a radula of the formula 12.6.1.6.12 with all teeth tricuspid (fig. 25); thus it proves to belong to Charopa (ef. Pilsbry, Man. of Conch., Vol, 9, pl.9, figs. $23,24)$.

FAM. IELICIDAE.

Rhagada leptogramma Pferffer. Broome ( $\% / 8$ 1911), 4 dead shells, max. d. $17.5 \mathrm{~mm}$.

R. reinga GRAY. Broome $(6 / 8$ 1911), 1 dead shell, d. $13 \mathrm{~mm}$. This species also oceurs at King's Sound (Hedley 1895). 


\section{FAM.BULIMULIDAE.}

Bothriembryon indutum Menke. Waaloo (Aug. 1911), many sps, max. 1. $33 \mathrm{~mm}$.

$$
\text { FAM. LIMACIDAE. }
$$

Limax arborum Bouchard-Chantereaux. Perth (24/8 1911), 4 sps, max. 1. $24 \mathrm{~mm}$. Its colouring is very characteristic. The shield has two lateral, entire, and one median, broken, band; out of the former a trace of a broken line emerges; the back has two latero-dorsal entire lines. This species has not before been recorded from Australia, and its occurrence at Perth is, like that of all Australian Limacidae, due to importation from Europe.

Amalia gagates Draparnaud. Perth $(24 / 8$ 1911), 1 sp., $1.17 \mathrm{~mm}$. It corresponds, both in exterior characteristics and in the structure of the radula, with this species from Europe, from where it has been introduced (cf. Musson 1891).

\section{FAM. SUCCINEIDAE.}

Succinea strigillata Adams \& ANGAS. Geraldton, under dry bark, many sps, max. h. $6.2 \mathrm{~mm}$, which agree very well with the figure and description in Cox (1868, pl. 15, fig. 5); the distinet striation is especially characteristic.

\section{FAM. ONCIDIIDAE.}

Oncis cinerea n. sp. (PI. 3, figs 75, 76). Body depressed, rounded ovate, with the notaeum densely papillose with rather regularly scattered small and larger papillae. Eyes only about 15, wide apart from each other, occupying chiefly the median part of the notaeum. Hyponotum smooth, its breadth about $1^{1 / 2}$ of the foot sole. Anus free, immediately behind the foot end. Respiratory orifice in the median line, at $1 / 3$ of the breadth of the hyponotum from the anal pore. Colour grayish, with a blackish dorsal stripe and an ovate blackish girdle round the median part of the back; towards the margins, black dots. Dimensions: length 9 , breadth 8.5 , height $3 \mathrm{~mm}$; breadth of foot sole 2, of hyponotum at its side $3.5 \mathrm{~mm}$. Locality: Broome, in mangrove mud $(18 / 61911), 1$ sp.

Though this specimen might be only a young individual, it camnot be referred to any of the 9 known species constituting the genus Oncis (cf. STANTSCHINSKY 1907). With respect to its shape, it shows close relation to O. marlensi Puate, which has, however, a uniform lemon colour. According to Stantschussky (1907), Oncidium and Oncis are srichtiger als durch l'bergangsmerkmale zusammenhängende Subgenera anzusehen. 


\section{FAM.LIUNAEIDAE.}

Isodora newcombi ADAMs \& AxGaS. Perth, from water holes ( $\left.{ }^{27} / 81911\right), 1$ sp., h. $10 \mathrm{~mm}$; wh. 4 . In its hollow umbilicus, it agrees well with the figure given by Sowerby in ReEve's Conch. Icon. 19 (Physa, pl. III, fig. 21). It has been found before near Mount Margaret, Western Australia (Smrn 1853), as well as in S. Australia (BEDNALL 1892).

I. (Ameria) reevei Anams \& Angas. Noonkanbah, Kimberley district, in grass, 1 empty shell, h. $6 \mathrm{~mm}\left({ }^{12} / \mathrm{r}\right.$ 1911). Thongh best agreeing with the figure of this species in ReEve, Conch. Icon. 19, 1874 (fig. 40), it differs in having a somewhat narrower upper part of the last whorl.

I. (Ameria) bonus-henricus Apars \& Angas. Noonkanbah ( $29 / 12$ 1910), 1 dead shell, $1.5 \mathrm{~mm}$, in its carinated penultimate whorl and the rounded last whorl with the strongly sloping aperture lip completely corresponding to fig. 29, $\mathrm{pl}$. $\mathbf{6}$ of E. A. Sмпти, 1883. The species is recorded from Arnheim Land (Sмитн).

Planorbis essingtonensis E. A. Surtir. In the Pandanus Spring near Noonkanbah, Fitzroy River ( ${ }^{10} / 2$ 1911), many specimens, max. diam. $4 \mathrm{~mm}$. A good description and figure is giren by E. A. Sмiтir 1883.

Ancylus australicus TATE. Fitzroy River, in sbillabong. (11/3 1911), 5 sps, max. 1. $2.9 \mathrm{~mm}$. The position of the apex is somewhat variable inasmuch as it may be nearly median or more distinctly to the right; it is always situated at the posterior third of the shell. The anterior slope is a little more convex than in the figures of E. A. Smin (1883, pl. 7, figs. 36, 37), the shells a trifle more depressed and the apex directed to the right (not to the left, as in the figures).

\section{FAM, PAISUDINIDAE.}

Paludina essingtonensis Fravifirt, Noonkanbah, Fitzroy River, in shillabong, (37/18 1910), 4 large and some small specimens, max. h. $24 \mathrm{~mm}$, and many dead young ones. The species is found at Port Fssington, in Victoria River, in Queensland and in tropical Australia (E.A. Sum 1883).

\section{FAM. UNIONIDAE.}

Diplodon wilsonii Les. Fitzroy River, many sps, max. 1. $85 \mathrm{~mm}(6 / \mathrm{s} 1911)$. Sow ERBY in RELve's Conch. Icon. gives Port Jackson as the locality of this species, while Snitu (1883) mentions its occurrence in Central Australia (Mount Margaret and Umbum). HEDLFY (1905) reports it from the Alberga River. In the nomenclature of Unionidae I follow Simpson (1900). 


\section{Mollusca from Queensland (and from South Australia).}

\section{a. Operculate land mollusca (Prosobranchia).}

FAII. CICLOPHORIDAE.

Leptopoma vitreum Sowerby. Atherton (Jan. 1913), 1 sp., h. 12 mm; Yarrabah (May 1913), 3 sps, max. 1. 15 mm; Bellenden Ker (May 1913), 5 sps, max. h. $12 \mathrm{~mm}$.

\section{FAI, PUPINIDAE.}

Hedleya umbilicata n. sp. (PI. 3, fig. 77). Shell pupiform with somewhat convex whorls, closely and regularly costulate, only the first apical whorl smooth. Last whorl somewhat ascending. Aperture square, peristome simple, reflected, not continuous, but interrupted on the body whorl and there replaced by a thin, finely granulated, callus; a short ridge-shaped callus close to the insertion point of the outer lip; columella straight, bounded by a short canal. Umbilicus wide and deep, surrounded by a keel springing from the end of the canal and separated from the base by a sharply impressed furrow. Colour light grayish. Dimensions: height 7.5 , breadth 3.2, height of the aperture $2.3 \mathrm{~mm}$. Locality: Evelyne (April 1913), 1 dead shell without operculum.

This species apparently belongs to the genus Hedleya Cox (1892), hitherto comprising only one known species, H. macleayi, collected at Cairns. 'This species agrees with the present one in the discontinuous peristome and the square mouth with the list-shaped callus at the lip insertion, as well as in the ribbed surface of the shell, characteristics which, consequently, are to be considered as generic, but it differs in its produced shape, the absence of an umbilicus, and the presence of a median furrow on the last whorl.

Pupina bilinguis Preiffer. Cedar Creek (April 1913), 6 sps, max. h. $8.5 \mathrm{~mm}$.

P. robusta Cox. Colosseum (November 1912), 3 sps, max. 1. $8 \mathrm{~mm}$. For the determination I am indebted to Mr. HEDLEY.

Pupinella densecostata Fulton (Pl. 3, fig. 78, text fig. 26). Mr. Hedley has kindly informed me that the present specimens belong to this species, described by FultoN in 1906 (Ann. Mag. Nat. Hist. 7, vol. 17). He writes: 'The umbilicus of yours is a little wider and the cord that margins it, is more distinct than in the typical form, but I have series from several localities that unite the extremes." I give a figure in order to illustrate the characteristics of the present shells, and a description completing that by FuLTON: Shell light grayish red-brown, very finely and densely ribbed (though often worn on the middle of the whorls). Both apical whorls smooth; the last whorl flattened above the aperture; the latter circular with 
a double peristome caused by a furrow which separates the lip callus from the edge. Canals two in number, very short, the right one bounded only above by a feeble tongue, the left one situated a little beneath the middle of the aperture and bounded both above and below by thickenings of the peristome. An umbilical keel emanating from the left canal and surrounding the rather narrow umbilicus. Dimensions: height 9, breadth 4, h. of aperture $2.7 \mathrm{~mm}$; whorls 6 . Locality: Colosseum (November 1912), 5 sps.

Radula 3.1.3 (fig. 26), median tooth with 3 broadly rounded cusps, first lateral with one broad median cusp and one small denticle on each side of it - by suitable position of the tooth a second minute denticle is visible on the inside -; second lateral with a strong cusp, a bifid denticle inside it and a simple smaller one on the outer side; third lateral with a bifid denticle and a broad cusp

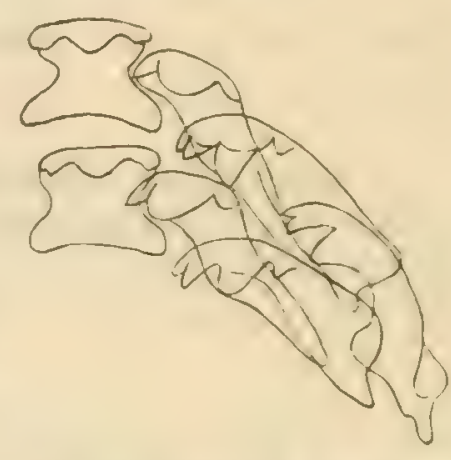

Fig. 26. IRaduls of Pupinclla densccostata FULTON. $\times 100$. but withont exterior denticle.

\section{b. Inoperculate land mollusca (Pulmonata).}

FAH. RHYTIDIDAE.

Rhytida sheridani Brazler. Atherton (Jan. 1913), 2 sps, max. d. $28 \mathrm{~mm}$ (colour dark brown); Malanda (Febr. 1913), I sp., d. $22 \mathrm{~mm}$ (colour yellowish brown); Cedar Creek (April 1913), 1 sh., d. $26 \mathrm{~mm}$. - Queensland, with no definite locality, 3 shs, max. d. $35 \mathrm{~mm}$. The whorls of this species are more rounded than in $R$. confuse Pfeiffer (cf. figs. 10-12, Taf. 6 in v. Moellendorff, 1902, Martini \& Chennitz, Conch. Cab.).

R. strangei Pfeiffer. Atherton (Jan. 1913), l sp., d. $19 \mathrm{~mm}$; Malanda (Febr. 1913), 1 sh., d. $15 \mathrm{~mm}$; Cedar Creek (April 1913), many sps, max. d. 22 mm; Bellenden Ker (May 1913), 1 sp., d. $14.5 \mathrm{~mm}$.

R. capillacea Férussıc. Colosseum (November 1912), 3 sps, max, d. $15 \mathrm{~mm}$; Carrington (May 1913), 1 sp., d. $18 \mathrm{~mm}$. This species, differing from $R$. slrangei only in the absence of spiral striae, is probably only a variety of the last-named form.

\section{FAM, NANINIDAE.}

Parmacochlea fischeri Suiti. Atherton (Jan. 1913), many sps, even with eggs, max. 1. (anim.) $31 \mathrm{~mm}$; Yarrabah (May 1913), $1 \mathrm{sp}, 1.21 \mathrm{~mm}$ (animal), $10 \mathrm{~mm}$ (shell); Millaa-Millaa (July 1913), 1 sp., I. $14 \mathrm{~mm}$ (anim.), Bellenden Ker (May 1913), 2 sps, max. 1. $16 \mathrm{~mm}$ (anim.). - According to HEDLEy, who has published a description of its anatomy and radula (1893), it is fairly common in N. Queensland $\mathrm{N}$. of $20^{\circ} \mathrm{S}$. 
Helicarion strangei PFEIFFsR. Blackal Range (18/3 1911), many sps, max. shell diam. 10, height $6 \mathrm{~mm}$; Atherton (Jan. 1913), 1 sp., d. $8.5 \mathrm{~mm}$ (shell); Bellenden Ker (Nay 1913), 1 sp., 1. $8 \mathrm{~mm}$ (shell). The animal of this species has, according to the present material, both the shell lobes granulated, the granula being partly blackish gray, partly whitish like the rest of the animal; on the right-sided shell-lobe there is a row of larger papillae in the middle line. The whorls of the shell are 3 in number at a diameter of $10 \mathrm{~mm}$.

H. bullaceus n. sp. (Pl. 3, figs. 79-82, text fig. 27). Shell depressed sphaeroidal, with slightly prominent spire and inflated whorls; aperture rounded lunate, very oblique, its breadth but little greater than the height; surface polished, shining, sculptered with low irregular transverse costae and with feeble spiral lines in the shape of low elevated angles. Colour light yellowish green with darker brownish transverse flames. The animal is characterized by the surface of both its shell lobes, which bear a few lengthened warts arranged longitudinally; for the rest the lobes are minutely wrinkled. These verrueae of the animal, as well as the sculpture of the shell, distinguishes this species from $H$. strangei. Dimensions: length of the animal

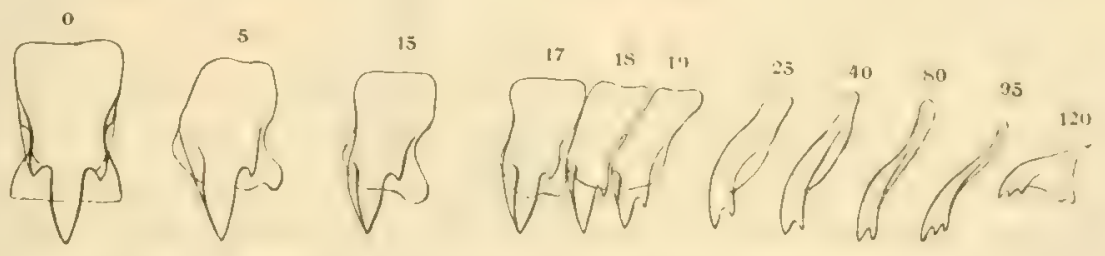

Fig. 27. Teeth from the radula af Helicarion bullaccus n. sp. $\times 300$

$30 \mathrm{~mm}$; 1. of the shell 19, height 14 , height of aperture 10 , breadth $12 \mathrm{~mm}$; whorls $31 / 2$. Locality: Bellenden Ker, 2 sps.

Radula (fig. 27) with about 120 teeth in one row at each side of the median tooth, which has a narrow central spine and a denticle on each side of its base; lateral teeth about 17, with an acute cusp and an exterior basal denticle, which in the first uncini is removed towards the apex of the spine; the sequent uncini to about 90 bicuspid and the outermost ones tricuspid. The last-named ones do not show, besides the denticles, any serration in the outer edge, such as is described for the subgenus Helicarion s. str. by P. and T!. SARASIX (1899).

Microcystis rustica Cox. Atherton (Narch 1913), 2 shs, max. d. $9 \mathrm{~mm}$; Herberton (Aug. 1913), 1 sp., d. $9.5 \mathrm{~mm}, \mathrm{~h} .6 .2$, br. of aperture $5 \mathrm{~mm}$; wh. 5 1/a. Shell depressed trochiform, its shape like $M$. Ireffli but smaller; whorls convex, somewhat transversly rugose through irregular lines of growth, extremely finely, spirally, striated; suture slightly margined and minutely undulating, caused by the rugations; umbilicus minute but scarcely covered by the slightly reflexed columellar margin. Distinct furrows running into the umbilicus, as mentioned by HEDLEY (1912); these begin comparatively far below the columellar sinuation (about 3 times its height from the body whorl). Colour grayish horny yellow; surface feebly lustrous. The species is distinguished from $\mathbf{M}$. kreffti, to which it is strikingly similar, in its smaller size 
when number of whorls is equal, a less shining surface, a grayish instead of an orange colour, and more pronounced transwerse rugations of the whorls, as well as by the presence of umbilical furrows, which are lacking in $M$. kreffti.

M. responsivus Hedley. Cooktown (Sept. 1913), 5 sps, max. d. $10 \mathrm{~mm}$. The specimens differ somewhat from that described and figured by HEDLEY (1912) in being larger and having narrower umbilicus; besides that, the outer lip of the aperture is inserted nearly horizontally on the body wall, while in HEDLEY's specimen it is very sloping. In the depressed shape, the light reddish gray colour, with a lighter base, and the fine striation, the present shells, however, agree very well with the typical 11 . responsivus. 'The small size of the latter seems to indicate a younger individual.

M. fulva n. sp. (Pl. 3, figs. 83-85, text figs. 28, 29, 30 b, 32, 35 a). Shell depressed with the spire slightly prominent; whorls convex, separated by a shallow, margined suture. Last whorl well rounded, not descending in front; aperture oblique ovately lunate, with simple lips; the lower lip somewhat convexly projecting in the middle. Columella sloping, its margin thickened, but scarcely reflected, leaving the greater part of the umbilicus uncovered, and with no sinuosity. A thin, minutely granular, callous layer joins the columella and the outer lip. Umbilicus narrow with no furrows within it. Surface of the shell polished, shining, the lines of growth feeble, irregular; no distinet spiral lines. Colour brownish orange, somewhat lighter below. Dimensions: diameter 9.5 ; height 6 , breadth of aperture 5.5 , height $4.6 \mathrm{~mm}$; whorls 5\% L. Localities: Colosseum (October 1912), 1 small sp., diam. 5, h. $2.7 \mathrm{~mm}$; Atherton (Jan. 1913), 4 sps, max. d. 9.5 mm; Malanda (Febr. 1913), 3 sps, max. d. $7 \mathrm{~mm}$; Cedar Creek (April 1913), 8 sps, max. d. $10 \mathrm{~mm}$; Carrington (May 1913), 1 sp., d. $4.5 \mathrm{~mm}$. - The specimens from Cedar Creek differ in being of somewhat larger size and having a somewhat more elevated spire than the others.

M. marmorata Cox. Gleen Lamington (November 1912), 1 sp., diam. 12.5, h. $8 \mathrm{~mm}$. - HEDLEY remarks (1912) that $\mu$. marmorata does not range so far north as to Port Curtis, from where it has been reported by 'Tryon (Man. of Conch. 1586). 'The present specimen also was collected considerably south of this place. It resembles the figure given by $\operatorname{Cox}(1868, p l \mathrm{~V}$, fig. 6$)$ in its elevated spire and angled periphery, for which reason it is to be referred to tho present species. The columella does not exhibit the same sinuosity as in $I I$. melica (HEDLEY 1912, pl. VIII, fig. 42), but is straight, vertical, and simple, reflected over half the umbilicus; the columellar margin shows transversal striae outwardly, which plunge down into the umbilicus.

M. kreffti Cox. Atherton (March 1913), 1 empty shell, d. $11.5 \mathrm{~mm}$; Malanda (Febr. 1913), $1 \mathrm{sp}$, diam. $10 \mathrm{~mm}$; whorls $4^{3} / \mathrm{s}$. The specimens agree completely with types in R. M. from Darnley Island, received from MAC LEAT. 
General Remarks on the Species of Microcystis.

As Hedery (1912) remarks, the Queensland forms of the genus Microcystis have not been definitively distinguished. They are very uniformly shaped and difficult to identify without types for comparison. In order to facilitate their identification and to contribute to a better knowledge of the genus, I have undertaken a close examination of the above species, with the following results.

Concerning the shell, $M$. marmorata is easily distinguished from all the others by its angulated periphery, as well as by its comparatively large size, $12 \mathrm{~mm}$ in diameter at $5 \frac{1}{3}$ whorls. The colour is yellowish gray as in $M$. rustica, equal above

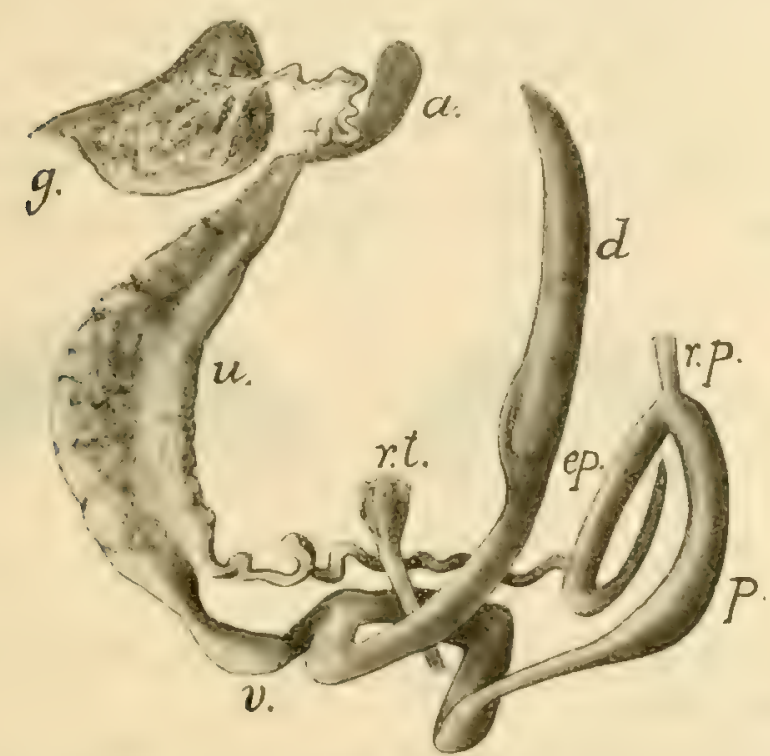

Fig. 28. Genital organs of Microcystis fulva n. sp. a albuminiparous gland; $d$. dart sac; ep. opiphallus; $g$. hermaphrodite gland; $p$. penis; $r . p$. retractor penis; $r . t$, tentacular retrnctor; $u$. utorus; $v$, vagina.

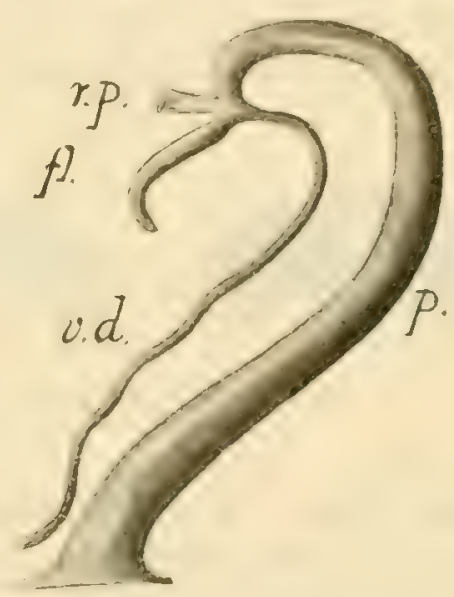

Fig. 29. Gonital organs of Microcystis rustica Cox. fl. flagellum; $p$. penis: $r . p$, retractor ponis, $v$. $d$. vas deferens.

and below, and the umbilicus is furnished with a few dense oblique furrows, but not infringed by any columellar sinuation.

The same yellowish or reddish gray colour is confined to $M$. mustica and $M$. responsivus; the latter is lighter above. Both have also spiral furrows entering the umbilicus and occupying a broader zone in $M$. rustica; a columellar sinuation is present in both, and the whorls are rounded. MI. rustica is more elevated (height of shell $>$ aperture breadth; in $M$. responsivus the height is=the aperture breadth). The outer lip is inserted at an acute angle to the body whorl in MI. metica and at nearly a right angle in $M$. responsivus; in the last-named the inferior aperture margin is slightly convexly projecting in the middle. There is only a slight difference in size: at $5^{1 / 3}$ whorls $M$. ruslica is $9.5, M$. responsivus $10 \mathrm{~mm}$ in diameter.

M. fulva and $M$. Rireffi differ from the three named species in their fulvous or orange colour, equal above and below. They have no columellar sinuation and 
no obvious furrows in the umbilicus, which are, however, indistinctly indicated. $M$. kreffii is more elevated and more or less distinctly spirally striated, its height $1^{1 / 4}$ of the aperture breadth, and larger, $11.5 \mathrm{~mm}$ in diameter at 5 whorls. $M$. fulva is smooth, smaller, $8 \mathrm{~mm}$ at 5 whorls, and its height is little more than the breadth of the aperture.

All the species in question agree in the following exterior characteristics of the animal. The foot sole is divided all along into a median and two lateral areas. The foot end has a slightly elevated upper corner but no horn. On the sides of the foot there run two epipodial furrows parallel to each other.

Between the different species differences prevail in colour and in the form of the shell lobes. In $M$. fulva the foot, on its dorsal side, is of a blackish blue colour; likewise the shell lobes, which are of nearly uniform lanceolate form; in $M$. responsivus the foot has a grayish blue back and the right shell lobe is grayish in its middle (and Jarger than the left one). M. marmorata and rustica are light coloured on foot and shell lobes, except that the right shell lobe of the former has a blackish base; in both the right lobe is the larger. Of the cervical lobes the left one is always

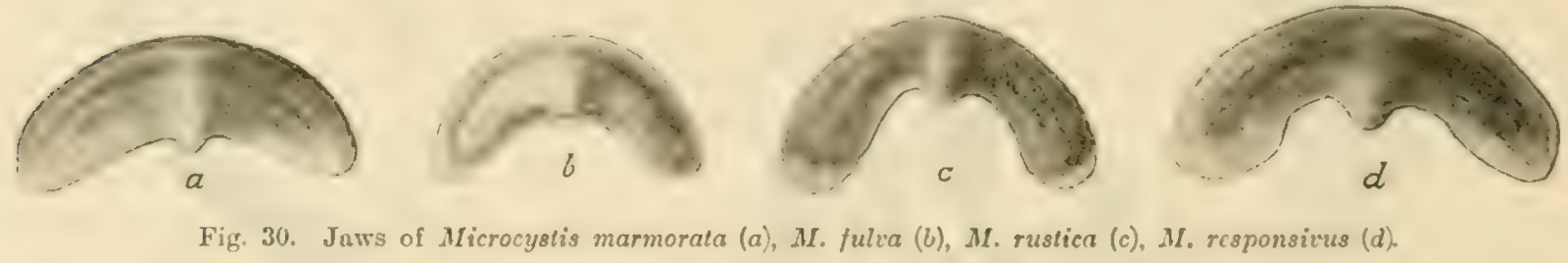

smaller than the right, which is divided into a columellar and a median portion; they are of the same colour as the shell lobes.

The genital apparatus exhibits the following common conditions: From the prostata gland, which is spread over the inside of the uterus, a simple, winding or straight, vas deferens leads to the penis, passing the right tentacular muscle. It has no accessory coeca. Above the insertion point of the vas deferens the penis carries a more (1I. fulva, fig. 28) or less (M. responsivus, rustica, fig. 29) produced flagellum. In the first case the vas deferens debouches in a sort of epiphallus (ep.). At the end of the oviduct is fixed a lengthened coecal sac, containing in $M$. fulva a chitinous cord corresponding to the dart of the Helicidae and certain Nuninidue; this dart sac seems to be of varying length in the different species.

The jaw has always a single median tooth, and it is more or less curved, so that the sinus on its lower side grows less pronounced in $M$. marmorata (fig. $30 a$ ) and fulva (b), more in $M$. rustica $(c)$ and responsivus $(d)$. Its colour is yellowish or brown.

The radulae (figs. $31-34$ ) have a tricuspid median tooth and bicuspid lateral and marginal teeth of different number, most in M. marmorata (about 150: 60.13. 1.13.60, fig. 31); M. fulva (fig. 32) has 25.13.1.13.25, M. ruslica (fig. 33) 26.14.1.14.26, M. responsivus (fig. 34 ) about 33.12 .1 .12 .33 . In $M$. marmorata 
and fulva the marginal teeth have the cusps of equal size, in $M$. responsivus a principal and a secondary cusp is present, and in M. mstica the latter is rather reduced in size and rather remote from the tooth end.

Thalassia pudibunda (Cox). Mount Tambourine (Oct. 1912), 4 cmpty shells, max. d. $14 \mathrm{~mm}$.

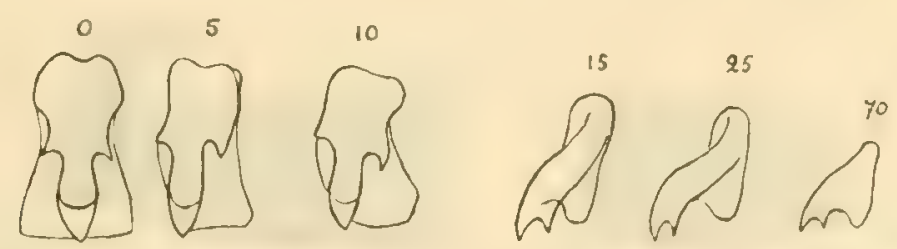

Fig. 31. Teeth from the radula of Microcystis marmorata Cox. $\times 350$.
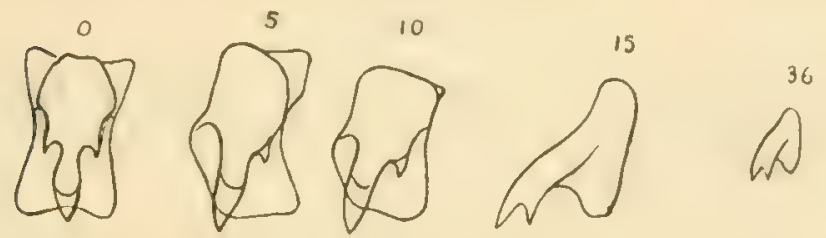

Fig. 32. Teeth from the radula of $M$. fulva $\mathrm{n}$. ap. $\times 500$.
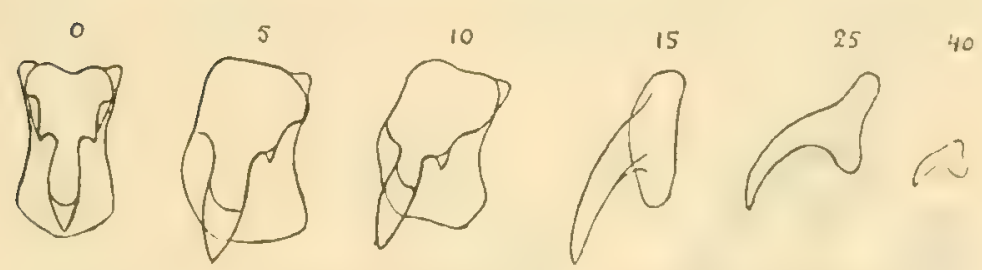

Fig. 33. Teeth from the radula of MI. rustica Cox. $\times 500$.

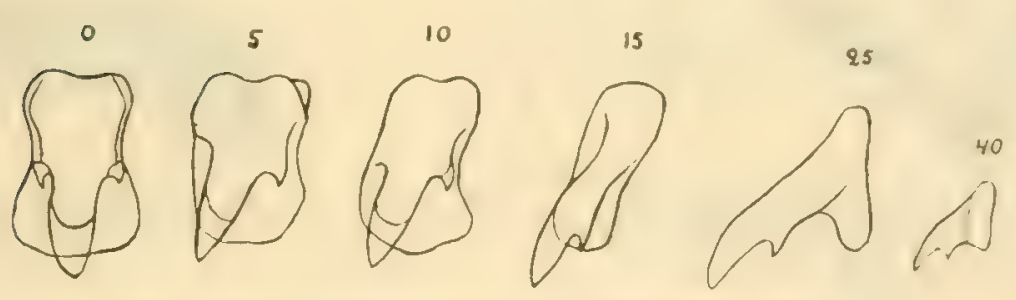

Fig. 34. Teeth from the radula of $M$. responsivus Hedrey. $\times 500$.

Macrochlamys suturalis n. sp. (Pl. 3, figs. 86-88; text figs. 35 b, 36-38). Shell trochiform, thin, with slightly convex whorls and shallow margined suture; last whorl subangulated, not descending in front; surface finely undulatingly striated, and with irregular lines of growth, polished and shining. Colour fulvous, suture marked by a thin dark brown line, and the umbilical funnel tinted by a faint reddish hue. Umbilicus narrow, half covered by the columella; aperture diagonally lunate; peristome thin, inserted at an acute angle on the body whorl; outer margin rather straight, 
then strongly and uniformly curving into the columella; the latter perpendicular, its margin in a short upper portion reflected and partly covering the umbilicus. MIaximal dimensions: diameter 15, height 11.5, height of aperture $7.3 \mathrm{~mm}$. Localities: Malanda (March 1913), 5 sps, max. d. 15 mm; Cedar Creek (April 1913), 2 sps, max. d. 14 mm; Bellenden Ker (Nay 1913), I sp., d. $15 \mathrm{~mm}$; Herberton (Aug. 1913), 2 sps, max. d. $13 \mathrm{~mm}$. - A more depressed variety with light reddish colour and some-
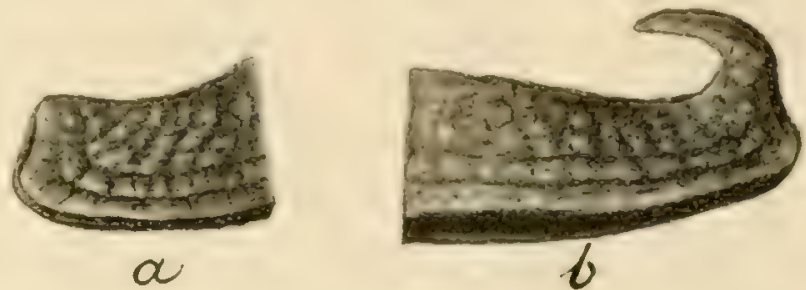

Fig. 35. Foot end of Microcystis fulva n. sp. (a) and Macrochlamys suturalis n. sp. (b).

what more pronounced striae (var. depressa) was found at Cairns (June 1913), 1 sp., diam. 13.8, h. 8, h. of aperture $5.6 \mathrm{~mm}$., and another, empty, shell at Atherton (Jan. 1913), d. 15.5, h. 10.5 , h. of ap. $7.3 \mathrm{~mm}$.

I have included this new species in the genus Macrochlamys BENson on account of the general pellucide appearance of the shell and the outer morphology of the animal, which has a large caudal horn (fig. 356 ) and two shell lobes, as well as the

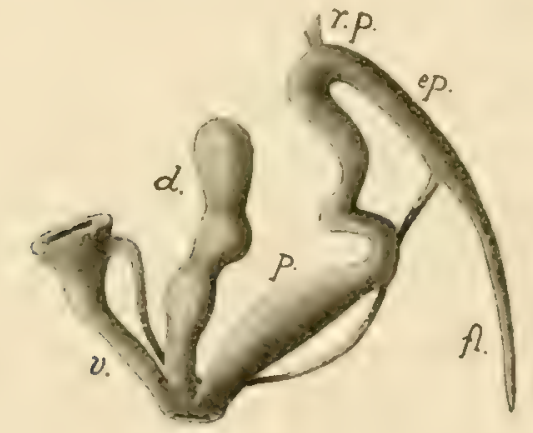

Fig. 36. Genital organs of Macrochlamys suturalis n. sp., distal parts. d. dart sac; $e p$. opiphallus; $f$. flagellum: $p$. penis :

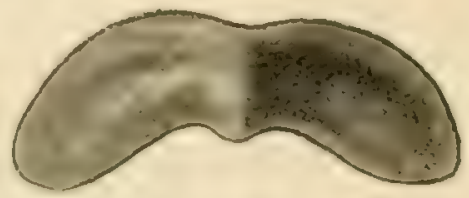

Fig. 37. Jaw of Macrochlamys suturalis n. sp.

left cervical lobe, divided into two portions. The foot sole is divided all along. Of the shell lobes, the right one is tapering, the left tongue-like. Colour of the animal uniformly gray (even the sole); shell lobes light coloured, cervical lobes grayish; mantle blackish.

The anatomy of the genital organs (fig. 36) corresponds entirely to that of Microcystis fulva (in simplicity and the absence of accessory coecal sacs). The penis has a long flagellum, and the vagina a lengthened dart sac with a chitinous cord-like dart. 
Jaw (fig. 37) reddish brown with shallow sinuosity. Radula (fig. 38) with 170 teeth in one row: 70.15 .1 .15 .70 , the marginals with subequal cusps.

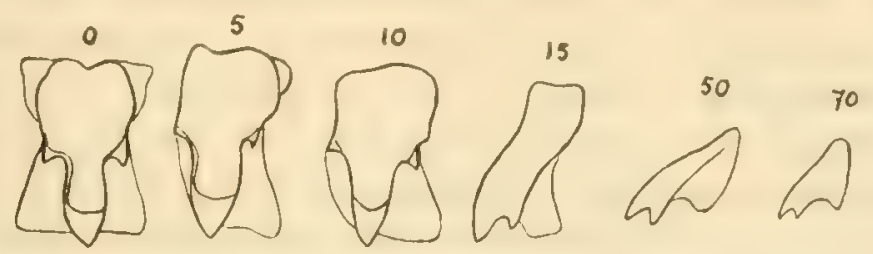

Fig. 38. Teeth from the radula of Macrochlamys suluralis n. sp. $\times 300$.

Sitala wilcoxi (Cox). (Figs. 39-41). Atherton (March 1913), 2 sps, max. d. $4.5 \mathrm{~mm}$; Malanda (March 1913), 2 sps, max. h. 3, d. $3.8 \mathrm{~mm}$; Cedar Creek (April 1913), 5 sps, max. h. $3.9 \mathrm{~mm}$.

An examination of the anatomy and the radula of this species made apparent its close affinity with Sitala anthropophagom HEDLEY (1894), from British New Guinea. The radula (fig. 39) has more than 150 rows of teeth, each row containing about 300 teeth, most of them uniform in shape and showing a denticulated outer margin (4-5 denticles) and a bicuspid apex. The formula is about 150.3 .1 . 3 . 150. All teeth have narrow, produced basal plates, and are extremely small, the largest
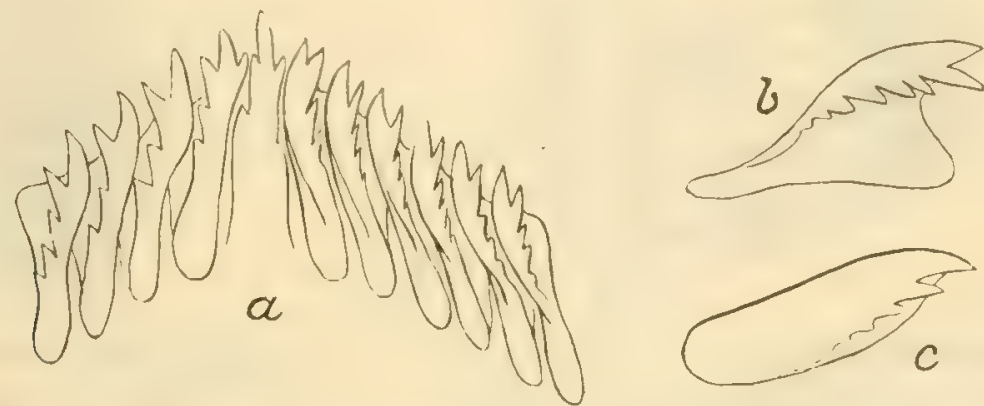

Fig. 39. Radula of Sitala wilcoxi Cox. $(a) . \quad b$ one of the inner, $c$ one of the outer teeth, seen from outer side.

measuring $8 \mu$ in length. The median tooth has a strong median cusp, at the base of which stand, somewhat obliquely, two smaller denticles, and farther away two other, still smaller, ones.

The jaw presents a curved segment without any projections, quite similar to the figures given by Godwin-Austex (18s4, pl. VIII, figs. $1 d, 2 d$ ).

In the genital organs (fig. 40 ), there is also a close resemblance to $S$ anthropophagorum (cf. HEDLEY 1894, pl. XXVI, fig. 24) as well as to S. allegia (cf. GoDwin-Austen 1884, pl. VIII, fig. 2 f.). There are no coecal appendages nor a flagellum in the male apparatus, and the female one has a spermatocyst and a dart sac.

The arrangement of the pallial organs (fig. 41) exhibits a twice reflected urethra, thus showing the characteristics of the group Sigmurethra, and a triangular nephridium extending beyond the pericardium. Except for two principal, nearly parallel 
pulmonary reins (the right one somewhat smaller), the renation of the lung is rather indistinct.

Exteriorly the animal has a foot with a mucus pore, surmounted by a small papilla (no horn), a sole longitudinally divided into three equal portions, and two epipodial furrows rumning all along the sides of the foot. The lobes of the mantle are small and indistinct.

O. F. V. MoellendorfF (1901) expresses a doubt whether HedLEY's S. anthropophagorum is a real Sitala. He says (p. 110): Konchyliologisch ist sie ohne jede Frage eine Coneupher und die Beschreibung der Weichteile ist so durftig, dass sich darauf keine sicheren Schlïsse basiren lassens. The examination of the present species and a comparison with HEDLEY's and GoDwIN-AUSTEN's descriptions, however, seems to me to remore all doubts as to its generic classification.

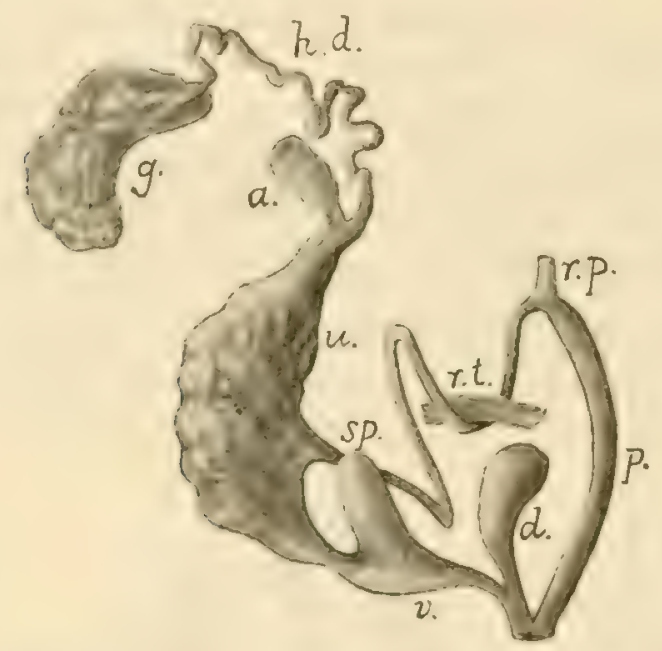

Fig. 40. Genital organs of Silala wilcoxi Cox. a. albuminiparous gland: $d$. dart sac; g. hermaphrodite gland: $h$. d. hormaphrodite duct; $p$. penis; $r$. $p$. rotractor penis; $r$. $t$. tentacular retractor; sp. receptaculum seminis; $u$. uterus; $v$. vagina.

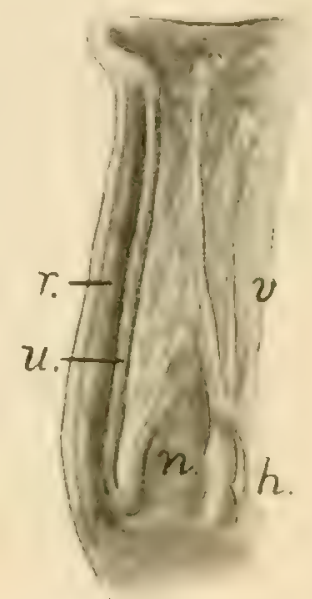

Fig. 41. Mantle organs of Sitala uil coxi Cox. h. heart; r. rectum; $u$. urethra; $v$. pulmonary voins.

The geographical range of the genus Sitala is rather wide, comprising N. E. Africa, Madagasear, India, China, Philippines, Celebes, New Guinea and East Australia.

\section{FAM. ENDODONTIDAE.}

Flammulina cumulus n. sp. (Pl. 3, figs. 89-91). Shell depressed trochoid, minutely perforate, irrecularly and densely costulate and microscopically longitudinally striated between the costae, and spirally striolated by impressed punctations between the longitudinal lines; thin and fragile, covered by a loose cuticula, streaked and marbled with lighter and darker brown flames, especially on the base. Whorls convex, separated by a deep suture, the last subangled in the periphery. Aperture lunate, somewhat broader than it is high; peristome simple, columellar lip slightly 
expanded at the insertion. Dimensions: diameter 7 , height 4.7 , height of aperture $2.8 \mathrm{~mm}$; whorls 5\% $5^{\frac{1}{3}}$. Locality: Bellenden Ker, 4,000 feet (May 1913), I sp. with animal.

This species belongs to the same group as Flammulina corticicola Cox figured by Hedlex (1912; pl. VIII, figs. 46-48), a species confined to New South Wales (Lismore) and recently found in Queensland (Tambourine Mountain). It differs from the present species in being more depressed and lacking the basal flames.

Flammulina cumulus is certainly to be regarded as a relic from a time when the genus had a wider distribution, comprising also northern Queensland (see sIntroduction", p. 4).

Endodonta (Charopa) intermedia n. sp. (P'. 3, figs. 92, 93). Shell small, very depressed, with the spire a little projecting beyond the body whorl. Surface densely and somewhat irregularly sculptured with transversal costae, the interstices between them transversally finely striated (parallel with the costae) and with dense microscopic spiral impressions. Umbilicus wide, its diameter somewhat exceding half the breadth of the last whorl. Colour, dark reddish brown. Dimensions: diameter 2, height $1 \mathrm{~mm}$; whorls $3 \frac{1}{2}$. Locality: Cedar Creek (March 1913), 3 sps.

The present form seems to approach $E$. stroudensis (from N. S. Wales), from which it differs, however, in having a deeper brown colour, a smaller number of whorls (presuming that the present specimens are full-grown), and a somewhat wider umbilicus; in $E$. stroudensis Cox the latter is equal to half the last whorl, in $E$.iuloidea Fonbes it is larger than in $E$. intermedia, or about $3 / 4$ of the breadth of the last whorl. Mr. HEDLEx has kindly verified the specific distinction of this form.

\section{FAM. HELICIDAE.}

Planispira strangulata HonBRoN \& JACQUINOT (= cyclostomata LE (YUHAoH). Colosseum (October 1912), 2 sps, max. d. 7.5 mm; Christmas Creek (Nov. 1912), many sps, max. d. $8 \mathrm{~mm}$; Cedar Creek (April 1913), 2 sps, d. $7.6 \mathrm{~mm}$; Evelyno (April 1913), in the jungle, 2 sps, max。d. $7.5 \mathrm{~mm}$. - Hederr has (1912) given good illustrations of this species and discussed its relations. For the synonymy cf. HEDLEY 1917.

P. rudis HedLey. Atherton (Jan. 1913), I young sp., d. $15 \mathrm{~mm}$, which shows the nearest agreement with the description and the figures given by HEDLEX (1912). The typical specimens were from south-west of Cairns and from Johnstone River serubs.

Chloritis bilabiata n. sp. (Pl. 3, figs. 94-96, text figs. 42, 43). Shell depressed conoidal with a convex base, and covered with a thin, velvet, stiff-haired cuticula. Colour, dull horn brown; spire slightly prominent; whorls convex, the lnst with an indistinct peripheral angulosity, abruptly and shortly descendent in front. Aperture obliquely lunate, lip thickened, expanded, and slightly reflected, of a dark hrown columr: columella concave, perpendicular, its margin triangularly expanded, partly covering 
the umbilicus. Behind the peristome a furrow-like contraction of the body whorl, and behind the. furrow a crest-like swelling of a dark brown colour, crossing the whole whorl. Umbilicus narrow, deep. Apical whorl smooth. Dimensions: diameter 10.5, height 7, aperture height $4.5 \mathrm{~mm}$; whorls 4\%. Locality: Malanda (Febr. 1913), 3 sps, thereof 2 small young ones.

This shell is closely related to Chloritis inflecta HEDLEy (1912) from south-west of Cairns. It differs from the latter in having the apical whorls smooth, the shell perforate and of smaller size - Ch. inflecta is $15 \mathrm{~mm}$ when there are $4 \frac{1}{2}$ whorls as well as in the dark-brown lip, while that of $C h$. inflecla is buff.

As external characteristics of the animal may be mentioned that the foot carries a dorsal longitudinal furrow and some oblique ones on its sides; there are no borders at the foot edges, and the sole is undivided. 'The foot has a uniform grayish brown colour, the mantle edge and the tentacles are blackish and the mantle part which covers the pulmonary sac is grayish, with small, regularly scattered, black dots.

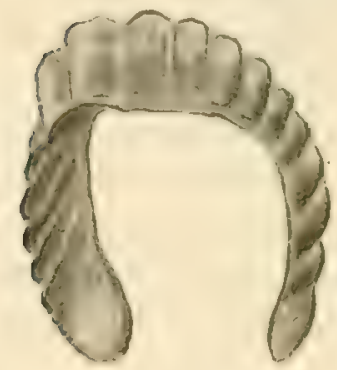

Fig. 42. Jaw of Chlorilis vilabiata a. sp.
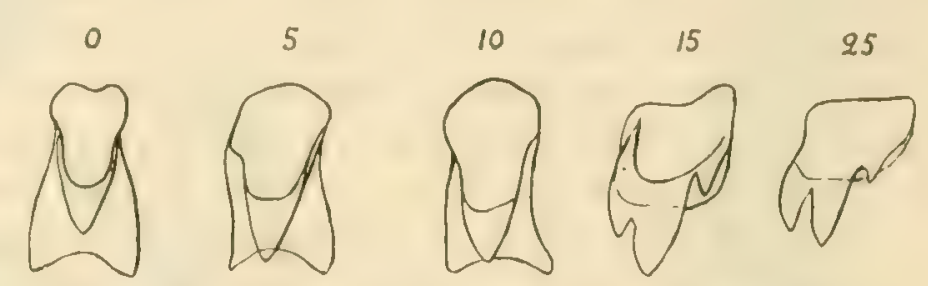

32

Fig. 43. 'Teeth from the radula of Chloritis bilabiata n. sp. $\times 750$.

The jaw (fig. 42) carries 16 strong ribs. - Radula (fig. 43) with about 32 teeth on each side of the median tooth. The latter is comparatively narrow, with a strong, simple cusp, equal in length to the basal plate. The 10 inner laterals with a similar cusp and without denticles; teeth $11-13$ with a small denticle outside the cusp, and the sequent marginals with a bicuspid mesocone and a small ectocone; the two outermost ones with a single obtuse mesocone and two ectocones.

Of the inner anatomy only so much could be observed on the badly preserved specimen that the penis is rather long, just as in Chloritis. Also in the structure of the jaw and the radula, the present species shows agreement with this genus, especially with the group Austrochloritis PILSBRY, but it differs in the peculiar shell form with its constriction and sequent swelling behind the lip, as well as in the smooth apical whorls, which bear no hair-points. These features give the species a close resemblance to the group Cristigibba of Planispira, which is confined to New Guinea. Whether the present form presents a real link between the latter section and the Australian group of Chloritis is a question for which only an anatomical examination can give the necessary basis of judgement. 
Ch. porteri Cox. Mount Tambourine (Oct. 1912), 1 sp., d. $10 \mathrm{~mm}$; Atherton (Jan. 1913), 1 sp., d. $9 \mathrm{~mm}$; Blackal Range ( ${ }^{20} / 10$ 1911), $3 \mathrm{sps}, \mathrm{max}$.d. $14 \mathrm{~mm}$; Evelyne, in the jungle (April 1913), 1 small sp., d. $6 \mathrm{~mm}$.

Ch. aridorum Cox. Colosseum (Oct. 1912), 2 sps, max. diam. 6.5 mm; Christmas Creek (Nov. 1912), 5 sps, max. d. 12 mm; Atherton (Jan. 1913), 3 sps, max. d. $15 \mathrm{~mm}$; Carrington (May 1913), 3 sps, max. d. $10 \mathrm{~mm}$; Bellenden Ker (May 1913), 1 sp., d. $7.5 \mathrm{~mm}$; Yarrabah (June 1913), many sps, max. d. $12.5 \mathrm{~mm}$; Cooktown (Sept. 1913), 6 sps, max. d. $10 \mathrm{~mm}$, under Eucalyptus bark; Malanda (March 1913), 1 sp., d. 11 mm; Herberton (Aug. 1913) many sps, max. d. 15 mm; Cedar Creek (April 1913), 3 sps, max. d. $7 \mathrm{~mm}$; Evelyne, in the jungle (April 1913), 1 sp., d. $5 \mathrm{~mm}$.

Thersites richmondiana PFEFFER. Queensland, no definite locality, l sp., h. 30, d. $49 \mathrm{~mm}$, with animal. Colour uniformly dark brown, lighter towards the apex.

T. castanea n. sp. (Pl. 3, figs. 97, 98; text fig. 44). Shell elevated globose with obtuse apex and shallow sutures; whorls moderately convex, the last one obscurely keeled at the periphery, somewhat descendent in front. Colour uniformly
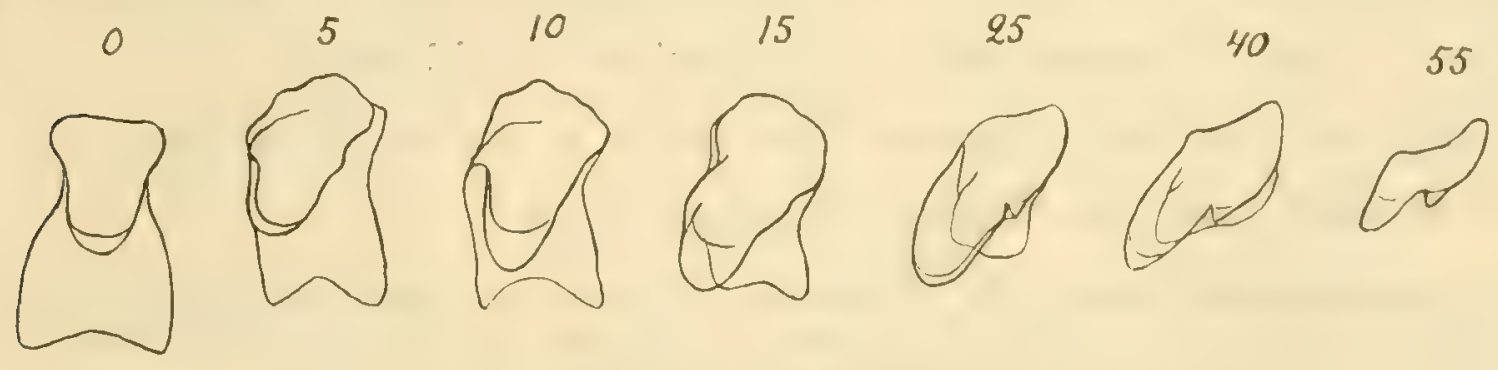

Fig. 44. Teeth from the radula of Thersites castanea n. $8 p . \times 100$.

dark chestnut, with 2 dark olive brown bands, the one peripheral, just above the obtuse keel, the other subsutural. An extremely fine, more or less obvious, whitish line bounds the suture. Aperture oblique, ovatelunate, peristome widened, expanded, of a violet brown colour, the columellar lip reflected, covering the greater part of the umbilicus, and joined to the outer lip by a thin callous layer on the body wall, spreading in an even curve. Umbilicus surrounded by an obtuse angularity at the base of the last whorl. Sculpture very characteristic, consisting of lengthened oblique rugae running in two different directions in alternating areas of irregular form and arrangement. Dimensions: diameter 42, height 38, aperture height $23 \mathrm{~mm}$. Localities: Cedar Creek (April 1913), I sh., d. $36 \mathrm{~mm}$, and many young specimens, max. d. $13 \mathrm{~mm}$; Evelyne (April 1913), many young sps, max. d. 9 mm; Bellenden Ker (May 1913), I young sp., d. 16 mm; Herberton (Aug. 1913), 1 sh., d. $14 \mathrm{~mm}$; Atherton (Jan. 1913), 2 sps, max. d. $33 \mathrm{~mm}$ (not full-grown); Malanda (Febr. 1913), 6 sps, max. d. $25 \mathrm{~mm}$ (not fullgrown).

A somewhat similar sculpture to that of this species exists in both the other true Thersites (richmondiana PFEIFFer and novachollandiae GRAY) most obvious in the base of the shell; but in these forms the rugae are coarser and, generally, divided into irregular granulations instead of being long and undivided. 
The jaw is dark brown with 12 strong ribs. The radula (fig. 44) has about ij) teeth on each side of the median tooth. The (about) 20 inner laterals have broad simple cusps and are without denticle; the exterior teeth from about 20 have an exterior denticle at the side of the large cusp.

Hadra bipartita F'érussac. Bellenden Ker (May 1913), l young sp., diam. $32 \mathrm{~mm}$; Queensland, no definite locality, 2 shs, the one of a more depressed, the other of a higher shape, the former measuring $\mathrm{d} .56, \mathrm{~h} .44 \mathrm{~mm}$, and having an obseure peripheral light band; the other d. $56, \mathrm{~h} .48 \mathrm{~mm}$, less obviously keeled and having a white subsutural band.

H. semicastanea Pfeiffer. Queensland, without definite locality, 1 sh.

H. forsteriana PFinfer. Cedar Creek (April 1913), 4 sps, d. $37 \mathrm{~mm}$; Carrington (May 1913), 1 sp., d. 27 mm; Atherton (Jan. 1913), 3 sps, max. d. 33 mm; Malanda (Febr. 1913), 1 sp., d. $18 \mathrm{~mm}$.

H. fraseri GRAY. Blackall Range (Sept. 1911), I sp., d. 33 mm; Mount Tambourine (Oet. 1912), 4 sps, max. d. $16 \mathrm{~mm}$; Christmas Creek (Oct. 1913), 2 sps, max. d. $12 \mathrm{~mm}$; Colosseum (Oct. 1912), 4 sps, max. d. $12 \mathrm{~mm}$.

H, incei Pfeiffer. Colosseum (Nov. 1912), 2 sps, max. d. $33 \mathrm{~mm}$.

H. grayi Pfeiffer. Adelaide (16/10 1911), 1 sp., h. $13 \mathrm{~mm}$.

Xanthomelon pachystyla PFeıferr. Queensland, without definite locality, 5 shells; Atherton (Jan. 1912), 2 sps, max. d. 24 mm; Carrington (May 1913), 1 sh., h. $8 \mathrm{~mm}$; Colosseum (Nov. 1912), l sp., h. $15 \mathrm{~mm}$.

X. durvillii Hombron \& Jicquinot ( - pomum PFenfer). Queensland, without definite locality, I sh. For the synonymy cf. HedLey 1917.

Papuina macgillivrayi Forbes. Bellenden Ker (May 1913), 3 sps, max. h. 2(), diam. $25 \mathrm{~mm}$.

FAM. ACAVIDAE.

Panda falconeri ReEve. Qucensland, without definite locality, 5 sps, max. h. 60 , diam. $65 \mathrm{~mm}$. - In 1914 IREDALE proposed to substitute the name Hedleyella for the generic name Panda, since the latter name was already in use, but as it has gained sanction as being generally employed, I cannot see any reason for the change.

Pedinogyra cunninghami Grar. l shell with no definite locality, showing transition to var. mülllfeldtiana PFEIFFer.

FAM. ACHATINIDAE.

Pseudopeas tuckeri Pfinfer. Malanda (March 1913), 1 sp., I. 8 mm. 
FAM. TORNATELLINIDAE.

Elasmias eucharis Brazier. Cedar Creek (March 1913), 1 sp., h. 2.5 mm., with embryoes in the uterus. - The specimen agrees best with the figures given by Hedley 1901 (Proc. Linn. Soc. N. S. Wales, 26, pl. 34, fig. 12) and Pilsbry (Man. of Conch., Vol. 23, 1915, pl. 30, fig. S). It is perhaps only a variety of $E$. waliefieldiae Cox (cf. Prlsbry, 1. c., pl. 30, figs. 9, 10), but seems to differ from it in having a shorter and comparatively narrower spire, a larger aperture and a narrower columellar expansion, characteristics which are all very typical in the present specimen. As this carries embryoes in the uterus, it cannot be, as HedLey (1. c. 1901, p. 705) seems to suppose, a young specimen of $E$. wakefieldiae, but must represent a distinct species or variety.

\section{FAM. LIMACIDAE.}

Limax agrestis Livié. Evelyne, in the jungle (April 1913), 1 sp., 1. $16 \mathrm{~mm}$. The colour is blackish brown, dark grayish down the sides; the shield and the foot end darkest black-brown. In having a median respiratory orifice at the shield it differs from the normal form of the species, but shell and radula exhibit quite typical characteristics.

\section{WAII. JANELLIDAE.}

Aneitea graeffei Humbert. Mount Tambourine (Oct. 1912), 3 sps, max. 1. about $45 \mathrm{~mm}$; Glen Lamington (Nov. 1912), 1 sp., l. about $45 \mathrm{~mm}$; Colosseum (Nov. 1912), l sp., 1. $55 \mathrm{~mm}$ (all measurements referring to contracted state). - The genus Aneitea, established by Gray (1860) for a species from the Island of Aneiteum, is represented in Australia by two species, the one described by HUMBERT (1864) and later on examined more in detail by HEDLEY (1889). The last-named author remarks on the present form (1892): After examining several hundreds...from various localities ranging along fourteen degrees of latitude, I reiterate the opinion formerly expressed (Proc. Roy. Soc. Queensland, Vol. V, pt. V, pp. 162-173) that only one species of this genus is yet known to inhabit Australias. According to HEDLEY (1889) the animal attains a length of $136 \mathrm{~mm}$. The second species, A. brisbanensis, was described by W. PFEIFFer in 1900.

\section{FAII. YAGINULIDAE.}

Vaginula leydigi Snготн. Atherton (Jan. 1913), 1 sp., 1. $30 \mathrm{~mm}$; Yarrabah (May 1913), 4 sps, max. 1. $42 \mathrm{~mm}$. The specimens show the characteristic blackish colour with a median yellow line, which is described by SmRotr $(1859,1891$ ) and HedLeY (1891).

V. hedleyi Snrrotr. Atherton (Jan. 1913), 1 sp., I. $25 \mathrm{~mm}$; Herberton (Jan. 1913), 1 sp., 1. $30 \mathrm{~mm}$.

K. Sv. Fet. Akad, Fandl. Band 52, N:0 16. 


\section{FAM. RATHOUSIIDAE.}

? Atopos (Prisma) australis Hersemaxy (Pl. 3, figs. 99-100: text figs. 45- in). Herberton (Jan. 1913), l sp., 1. $45 \mathrm{~mm}$. - As no good description or figure has been published either of this species or the closely allied A. prismatica TAPPARONE Canefri (1883), I am not sure which of these species the present specimen represents. It is different from both in the dark, blackish gray, foot sole, but whether this is a specific or individual characteristic it is impossible to say without examining

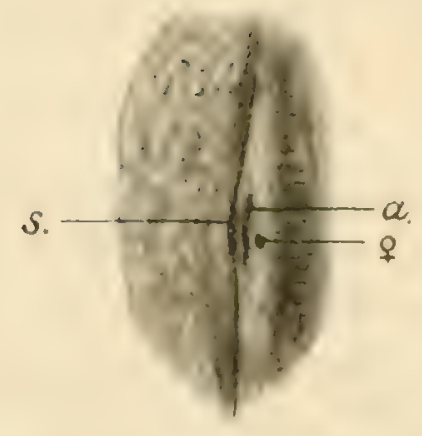

Fig. 45. Atopos australis'?) Hirressas. Position of tho openings: $a$. clonca (anus and urethra pore); s. pulmonary orífico; + fomalo gonital opening.

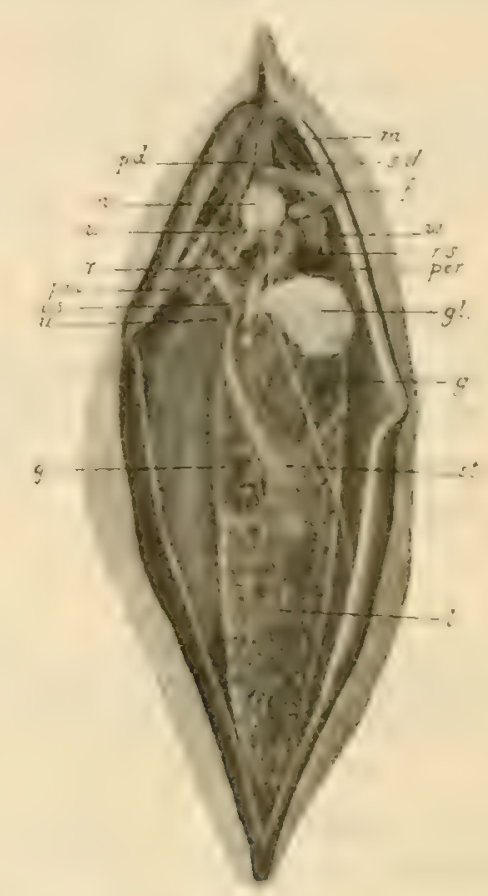

Fig. 46. Anatomy of Alopos australis (?). $f$. foot gland; $g$. hermaphrodito gland; gl. albuminiparous gland; $l$. liver; $m$. muscles; $n$. central ganglia; $p$. $d$. penis gland: $\mu$. $m$. retractor penis; per. pericard; $r$. rectum; 8 . d. xspin gland”; r. s. radula sac; $s$. stomach; $u$. nephridium; $v$. s. receptaculum semi. nis: $v$. "white glands". The white broken line marks the extension of the stomach lumen.

more comprehensive material. I therefore prefer to range it under the previously known Australian (Queensland) species and to give a good figure and a detailed description for future identification.

The present specimen had the anterior end strongly retracted beneath its notum, so that neither tentacles nor mouth were visible. The exterior characteristics agree with the descriptions that SrMromir (1891) has put together from the literature on the allied forms. In its outline the body has a narrowly elliptic shape with tapering ends; the dorsal side is very elevated and forms a sharp keel which gives the body an equilaterally triangular section with somewhat convex sides (ef. fig. $a$ of Simrotr 1891). The sides of the notum are densely set with larger and smaller, regularly 
rounded and rather uniformly spread verucae. On the under side three portions appear, the median one being the sole, and showing a close transversal rugation, the lateral ones being the equally broad hyponota, which are warty like the upper part of the body. The foot sole is shorter than the notum, becomes narrow towards both ends, which are rounded, and is separated all round from the hyponotum by a rather shallow furrow. In the latter there appear the following openings (fig. 45): in the foremost end close to the right of the mouth the male genital orifice; far back on the right side (in the first fifth of the body length) a group of openings, namely the female genital orifice as a small rounded pore below, above it the cloaca, or the joined anal and nephridial openings $(a)$, as a lengthened slit, and lastly, just in the bottom of the mantle furrow, the minute inspiratory orifice $(s)$. - The colour of the animal was a uniform light brown, except for the blackish, medially lighter, sole.

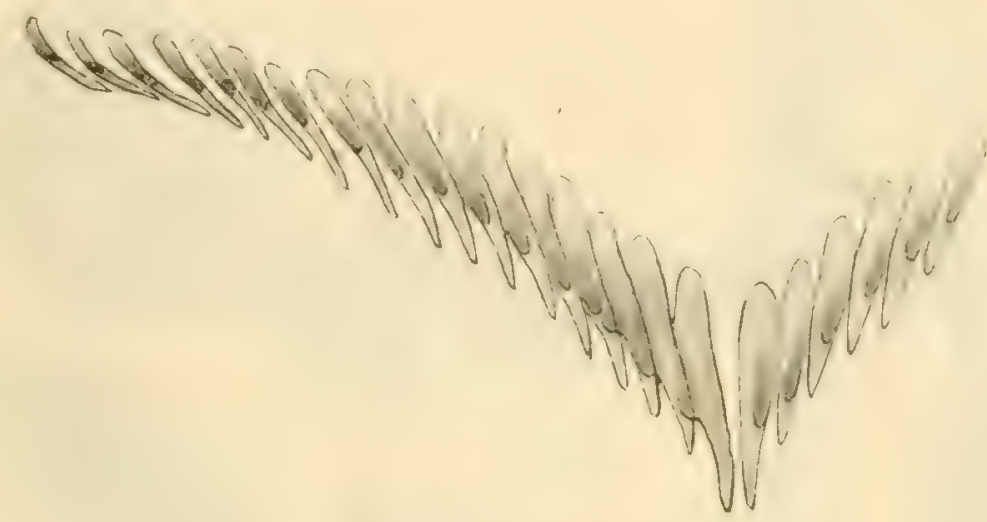

Fig. 47. Radula of Atopos australis(?). $\times 145$

\section{Anatomy of Atopos anstralis.}

The figure 46 gives a scheme of the inner organization, which in all essential respects agrees with the description by Snirotr 1891. 'The alimentary canal begins with a lengthened muscular pharynx without jaws, which receives on both sides the ducts from the triangular salivary glands. In the immediate continuation of the pharynx follows a cylindric radular sac $\left(r . s_{\text {. }}\right)$, which is exteriorly not markedly set off from the former. In front of the radular sac, on its upper side, a very narrow, thin-walled oesophagus emerges; it passes through the nerrous centrum, stretches backwards on the right body side and opens in its median line into the spacious liver $\left(l_{\text {. }}\right.$, which extends backwards as a narrowly conical, slightly lobed, whitish gray sac. Close to the junction of the oesophagus with the liver emanates the intestine, which describes a curve towards the dorsal side between the liver and the hermaphrodite gland $\left(g_{0}\right)$ and then leads directly to the anus.

The radula (fig. 47) is rather narrow with only $19-22$ teeth in the oblique rows on each side of the naked rhachis. The teeth are uniformly hook-shaped with one large cusp only, as in Testacella, but the outermost laterals are smaller than the 
others (cf. Sinmotil 1891 and P. \& F. Sarasin 1899). The largest teeth have a length of $0.17 \mathrm{~mm}$.

In the vicinity of the mouth debouch some glands in the median line of the foot, one pedal gland (fig. $46 f$ ) which is bent back upon itself, so that its posterior part is reflected foreward. It has a flattened appearance and is indistinctly divided all along. On the sides of the foot gland there emanate a pair of glands (s. d.), which Snmotr has called spinndriisen and P. \& F. SARASIN have named simrothsche Drüsen; these have tho same structure as Snmotr describes, with a distal cylindrical muscular portion and the proximal, likewise cylindrical whito glands (Simroti), which are connected by a long, complicately winding, thread-like canal. The right-sided spin gland, opened in connection with the penis and might perhaps

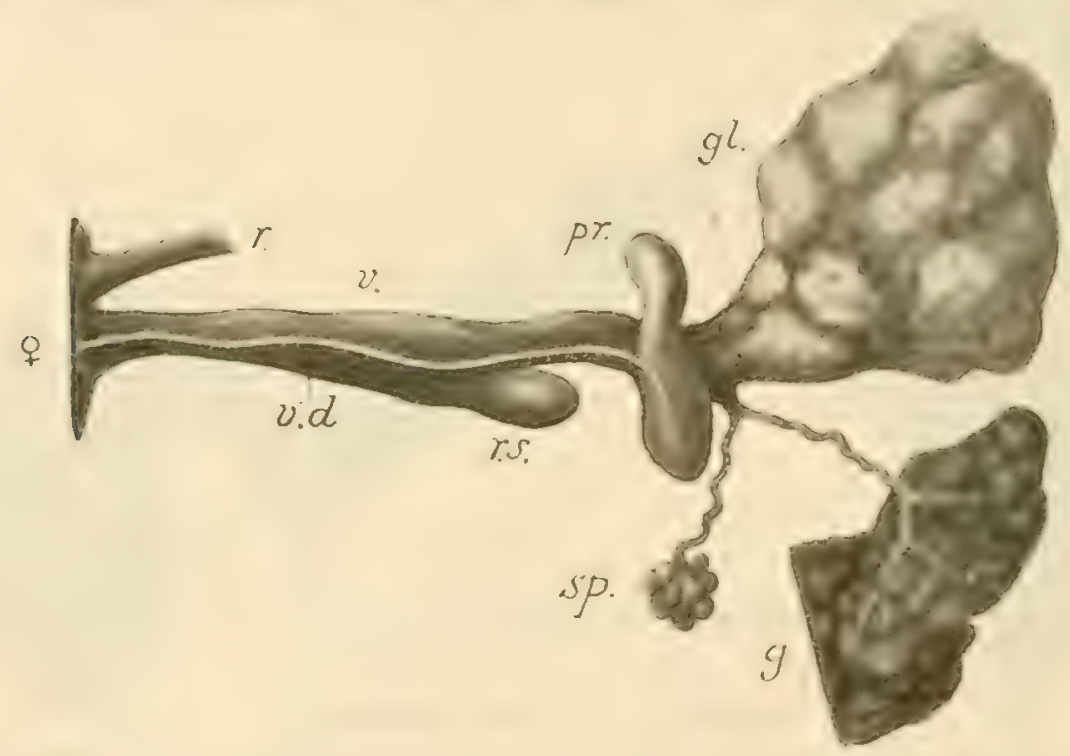

Fig. 48. Female genital organs of Alopos australis(?). g. hermaplurodito gland: $g l$. albuminiparous gland: $p r$. prostata; $r$. rectum: $r$. s. receptaculum seminis;

$s p$. spermatocyst; $v$. vagina; $v$. $d$. vas deferens; + female genital orifice.

be an appendix to it; the shite gland $(w$.$) exists also on that side, but the whole$ apparatus is somewhat thinner than the left-sided one. In the distal cylindric portion of both spin glands a short cartilagineous staff is encluded with a short point in its foremost abruptly rounded end.

The genital organs (figs. 48, 49). The hermaphrodite gland (g.) occupies the anterior right part of the visceral mass and consists of some large lobes of a reddish brown colour. From these the hermaphrodite duct emerges as a narrow, winding canal. To this joins a short branch from a spermatocyst (sp.), composed of many small sacs. The hermaphrodite duct debouches jnto the oviduct, which is at this point furnished with two appendices, on the one hand an albuminiparous gland $(g l$. of irregular shape with largely folded walls, strongly swelling in water, and of a milky white colour, on the other hand a narrowly lanceolate prostata ( $p r$.$) . From$ this latter the vas deferens $\left(v, d_{0}\right)$ emerges in the shape of a very thin and straight, 
(not winding) canal. From the albuminiparous gland the oviduct continues as a strongly thickened straight tube, which passes into the vagina $(v$. $)$ carrying a sessile pear-shaped receptaculum seminis $\left(r, s_{*}\right)$. 'The vagina debouches immediately behind and beneath the rectum $\left(r_{0}\right)$, and near its opening the vas deferens penetrates the body musculature and then runs encluded into it towards the front to the male genital opening. Here the vas deferens enters again into the body cavity (fig. $49 a$ ) and passes, after some curls, into the posterior end of the penis immediately in front of its retractor $\left(m_{0}\right)$, which is inserted on the right side of the body, far behind the anus and far behind the insertion of the tentacular muscle. The penis proper is rather short, soft, without special armature furnished only in its end with a number of slightly obliquely running riblets (fig. $49 \mathrm{~b}$ ). It rested retracted into a long sheath. Close by the distal end of the penis sheath or sac the right spin glands $(p . d$.$) joins it, thus being in$ the same relation to the male apparatus as the spenis gland in part of the Vaginulidae and in Oncidiidae; in the last-named family this organ has a habitus that strikingly recalls this spin gland, of Atopos. I therefore consider it possible that these organs are homologous and that the penis gland of Oncidiidae and Vaginutidae might have originated from a spin gland like tliat of Atopos, while the corresponding left-sided gland has become completely reduced. For such an

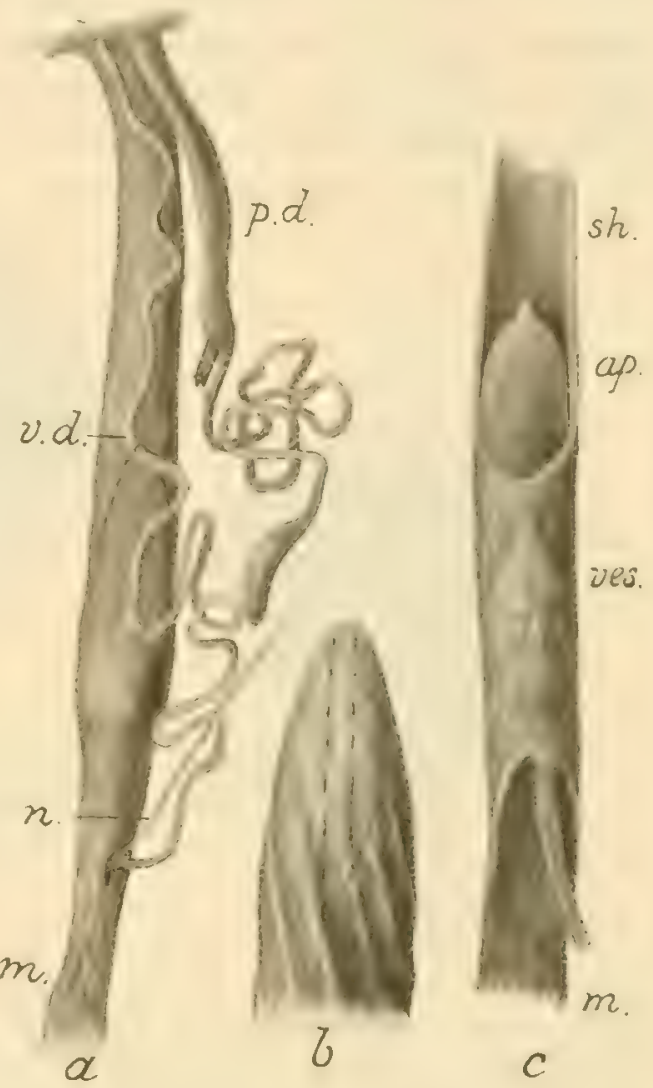
opinion speak also the observations made by Fig. 49. Male genital apparatus of Alopos austra. the two SARASIN on the ontogeny of the penis lis? " land in Vaginula. where it arises apart from $b$ end of the penis; $c$ end of tho penis gland:ap. gland in Vaginula, There it arises a part from its apex; m. muscle of the sheath (sh.); ves. vesicula. the penis. They state (p. 98): "Auch die Penis-

drüse scheint sich von aussen her selbständig als Hautdriise anzulegen und mit der Penisscheide secundär zu gemeinsamem Ausführgang zu vereinigen。»

The nervous system (fig. 50). With Simroti I have found the ganglia very close together with only a narrow central opening for the passage of the oesophagus. The cerebral ganglia $\left(c_{0}\right)$ are connected by means of a very broad commissure and also by a thin inferior cord, from where a nerre trunk (1) passes towards the month. From the cerebral ganglia nerve trunks lead to the tentacles (2) and into the musculature (3), as well as connectives to the buccal ganglia (5), which are situated beneath the radula sac (cf. SIMROTH 1891). The posterior half of the nervous ring is occupied by the parietal ganglia (par.), which send nerves to the penis and the 
musculature of the body sides. A very inconspicuous pleural ganglion $\left(p l_{\text {. }}\right)$ exists between them and the cerebral centra. At the hindermost side of the nervous ring, between the parietal ganglia, a very indistinct visceral centre $\left(v_{0}\right)$ is recognized by the visceral nerve (11) that emanates here near the right parietal ganglion and follows the intestine backwards, till it ramifies in the hermaphrodite gland and the liver. - The whole under side of the posterior portion of the nerve centrum is occupied by the elongated pedal ganglia (p.). From their anterior end they send nerves to the foot gland (6), and from the posterior end a very strong nerve cord on each side stretches backwards innervating the foot and the hyponotum (10). The statocysts were not observed.
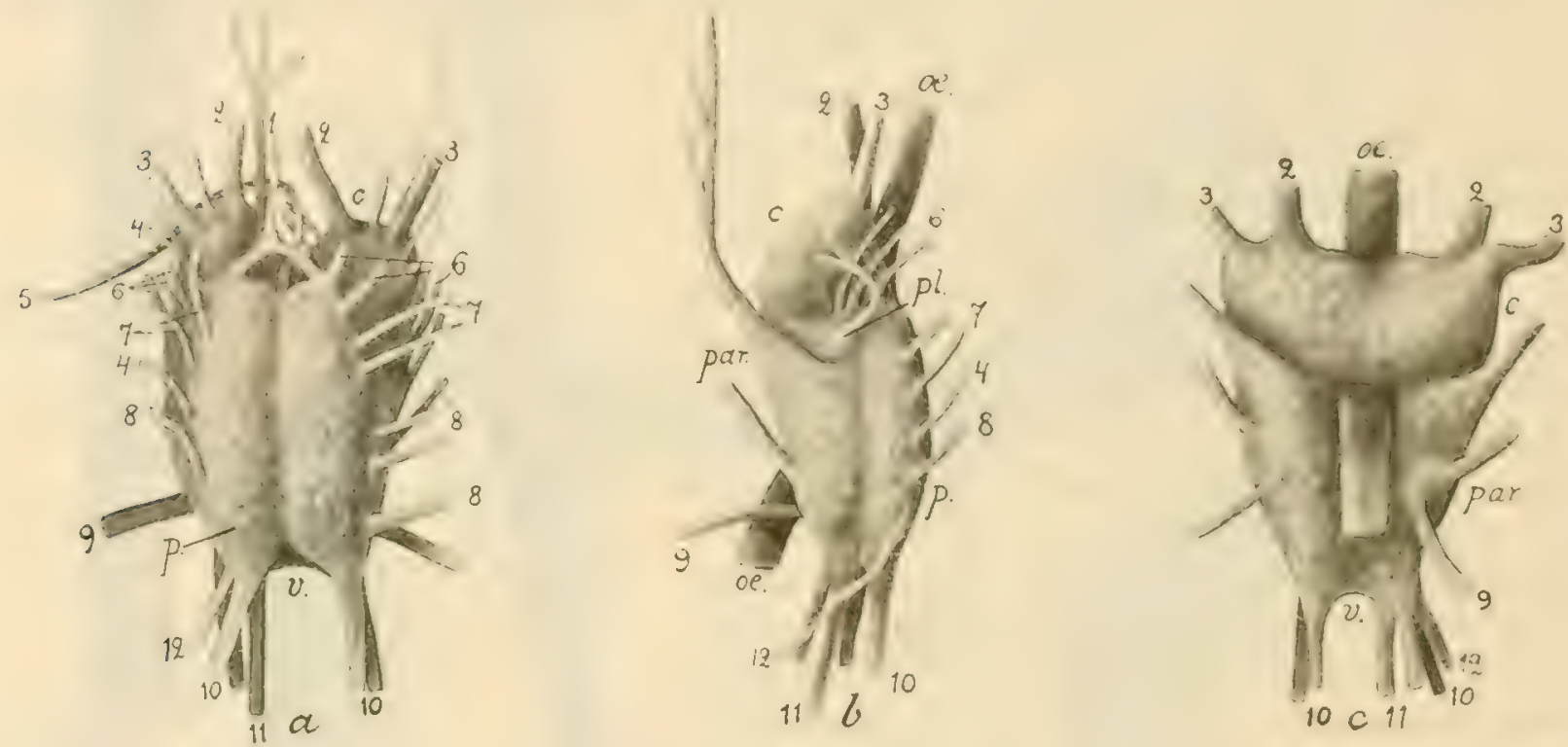

Fig. 50. Nervous system of Atopos australis(?): $\boldsymbol{u}$ from below; $\boldsymbol{b}$ from right sido; $\boldsymbol{c}$ from above. corebral ganglia; ac. oesophagus; $p$. pedal ganglia; par. parietal ganglia; $p l$. pleural ganclia; $v$, visceral ganglion; 1 labial nerves; 2 tentacular nerves; 3 nerves to the musculature of the anterior body part; I nerves to the anterior part of penis; 5 buccal nerve; 6 nerves to the foot gland; 7 nerves to the anterior part of the foot; 8 nerves to the anterior parts of the body sides; 9 penis nerve (to posterior part of penis); 10 nerves to the posterior parts of the body sides; 11 visceral nerve; 12 pallial nerve to posterior part of notum.

'The pallial organs (fig. 51). In the median line of the body, just under the end of the radular sac, the pericardium $(p$.$) appears as an ovate bladder, and in it$ the light yellowish heart (h.) consisting of a posterior auricle and the ventricle in front of it. The pericardium was designated by SIMRotr (1891) as a lung (cf. his figs. 19 and 21 ). In reality the lung is situated behind the pericardium and above the nephridium, something which is at once obvious from the fact that the auricle is turned against, and its blood-ressels intimately branched into, these organs. 'Their intimate comection secms to have caused Sumoti to confoumd them when examining his sections. What Smmotu has described as a mucus gland (:Sichleindrise:) seems to correspond to an outer portion (l.) of the lung, ${ }^{1}$ for into this portion leads the

${ }^{1} \mathrm{P}$. and F. SArasin have found in this place a glandular expansion of the urethra, which they consider to be Simroti's s Schleimdrüses. 
pulmonary orifice $\left(s_{0}\right)$ which is situated in the peripedal furrow above the anus $(a)$. The outer pulmonary sac stretches along the right side of the perieardium (and partly covers it); in its posterior end it becomes narrow and communicates here with the posterior or respiratory portion of the lung, which is intimately connected with the nephridium (n.) in the same manner as in Oncididae (cf. Plate 1893). From the nephridium, which occupies an orbicular space behind and on the sides of the pericardium (even below the outer pulmonary sac), the reno-pericardial canal ( $\left.p . t_{0}\right)$, on the one hand, leads to the pericardium, where it debouches on the right side of the auricle,

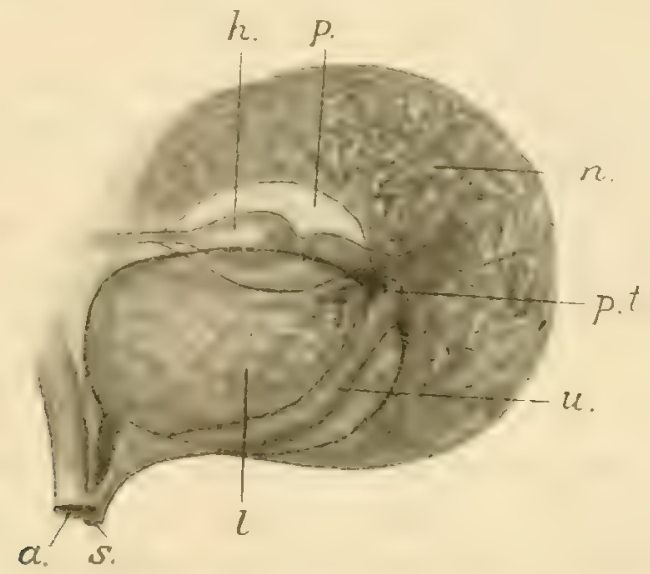

Fig. 51. Mantle organs of Atopos australis(8): a cloaca (anus and urethra pore); $h$. ventricle of the heart; $l$.lung; $n$. nephridium: $p$. pericardium; $p . t$. pericardial tube of the nephridium; s. pulmonary orifice; $u$. urethra.

and on the other hand, a urethra ( $($ ) $)$ runs along the posterior and outer side of the outer pulmonary sac; this urethra joins the rectum, thus forming a cloaca just as in Oncidiidae (ef. Plate 1893).

It should be remarked that the above account of the organization is based on the dissection of only a single specimen. I regret that no more material of this interesting form has been at my disposal for examining the finer details in sections. Just in the anatomy of the mantle organs and their mutual relations are the chief points for judging on the affinities to be found. At present no exact idea of the organization is obtainable from the discrepant descriptions of Atopos given by SIMROTH on the one hand and by P. \& F. SARASIN on the other, which both differ from the above statements. The two SARASIN give a somewhat schematic figure of the mantle organs (fig. 141), but they do not mention anything about the heart and the nephridium. As to Simrotr's description, they make no attempt at comparing it with their own results nor enter into a criticism of it. 'They only see in the urethra gland, existing in the form examined by them, something equivalent to his 
Sichlemdriises, and give no other expression of opinion about his investigations on these organs than the following words (p. 112): s'mrotr hat diese Drüse auch gesehen, doch wurden von ihm die Mantelorgane nicht richtig erkannt. By such circumstances a future investigation must be awaited before complete certainty as to the organization of the genus Alopos is attained, as well as, basing thereon, an idea of its affinities is possible to gain. With respect to the relations within the genus, the present species differs from the forms described by sinnotin in having a broader hyponotum and in the structure of its genital organs; further the retractor penis inserts rather far behind the retractor of the right body side. A muscular knot like that of $A$. semperi (cf. Smrotir, 1891, fig. 19a) is present on the bottom of the body cavity behind the mouth. 'The differences named are not more important than that they justify at the most tho establishment for this and the nearest allied forms of a distinct subgenus, Prisma, proposed by Simroti (1891).

A parasitic nematod was found in the rectum of the present species. It will be described by Dr. Ditlevsen, who has preliminarily named it Atopoeca inlestinalis.

\section{FAM, LIMNAEIDAE}

Isodora gibbosa Gould, var. brevispira n. Atherton (Jan. 1913), in a brook. many sps., max. h. 12.5 ; ap. h. $9 \mathrm{~mm}$; whorls 5 . On account of the gibbosity of the last whorl, which is most swollen above the middle, I have referred these specimens to $I$. gibbosa; but they differ from the typical form (figured by E. A. Surtu 1883, pl. 6 fig. 4) in a smaller (both narrower and shorter) spire. 'The colour is horny brown. 'The shape of the aperture, which is widened below and obtusely angled above, is typical.

FAH.PALUDINIDAE.

Larina strangei A. AdAMs. Cedar Creek (Narch 1913), 4 sps, max. h. $4.4 \mathrm{~mm}$.

\section{FAM. UNIONIDAE}

Diplodon shuttleworthii TAK1 (= Unio angasi SowrRuY). Coleman River, $\mathrm{X}$. Queensland (Sept. 1913), one large shell, 1. $90 \mathrm{~mm}$, and three smaller ones. The former agrees very well with fig. 282 in ReEve (Conch. Icon. 16) and with the description given by E. A. SuIti (1883) of the livid lustre of its nacre, which reminds one of the interior of a Haliotis; the small shells, max. 1. $19 \mathrm{~mm}$, have the posterior laterals simple in both valves, which may perhaps be a characteristic of a young specimen.

FAM. CYRENIDAE. $82 \mathrm{~mm}$.

Cyrena ceylanica Cuesnitz. Queensland, without definite locality, 1 sh., I. 


\section{Subfossil mollusea from the eaves at Chillagoe.}

Planispira praehadra n. sp. (Pl. 3, figs. 101-103). Shell depressed, conical, with slightly raised spire and inflately convex basal portion, separated by a sharp peripheral carina. Whorls slightly convex, nearly flattened and separated by shallow sutures, the last one shortly descending in front. Aperture oblique, broadly lunate, with the lip slightly expanded; columella perpendicular with reflected margin, half covering the small umbilicus. Sculpture: whole surface roughly rugated in oblique direction, here and there two systems of rugae crossing each other; the rugae carrying lengthened hair scars placed in spiral series. Colour milky white, somewhat

translucent, with two light brown bands, one above and the second just below the peripheral carina. Maximum dimensions: diameter 25 ; height 16.5 ; h. of aperture 11 , br. of ap. (from columellar to outer lip margins) $14 \mathrm{~mm}$. Whorls $5 \%$.

About eight large and small shells were collected, most of them covered with an earth crust, under which the surface of the shell had a fresh appearance. The species is closely related to the large forms of Planispira from Queensland, described by HEDLEY in 1912, but it differs from them in its more elevated spire and in its rough sculpture with the elongated hair scars, which strongly recall the sculpture of Hadra forsteriana. The new species appears to be a transition form between the latter species and a large Planispira, such as $P$. delicala Heduer (1912). In its young state $H$. forsteriana is still more like $P$. praehadra in its keeled periphery, but the shape of aperture, with its sloping, not horizontal, under-margin, distinguishes it from the present species.

Microcystis antiqua n. sp. (Pl. 3, figs. 104-106). Shell depressed, conical, with slightly projecting spire and well rounded body whorl, narrowly umbilicated; suture broadly margined. Aperture produced lunate, with simple peristome, the outer lip immediately declining from body whorl, evenly rounded all round, under lip somewhat convexly projecting in the middle, columellar margin not reflected but somewhat thickened and with a small sinus. Surface with microscopical spiral striae and slight rugations across the whorls, the latter appearing most obviously on the base. Within the umbilicus a few furrows appear at the columellar margin. Max. dimensions: diameter 7.5 , height 4.5 ; h. of aperture 3.1 ; br. of ap. $3.7 \mathrm{~mm}$; whorls $5 \frac{1}{3}$.

Though very like $M$. fulva, the above species differs from it in possessing a somewhat more elevated shape and a more contracted spire, so that 5 complete whorls are present at about $6 \mathrm{~mm}$ diameter; further the umbilicus is a little wider and furnished with some distinct furrows within. It resembles $M$. fulva in having the under lip of aperture broadly convexly projecting, wherein it differs from $M$. rustica; on the contrary, it resembles the latter in its elevated form and the distinct 
umbilical furrows. On the whole it seems to be intermediate between $\mathbf{M}$. fulvu and $M$. metica, though differing from both in being of smaller size.

Hypselostoma australis n. sp. (Pl. 3, figs. 107-109). Shell pyramidal, with convex whorls and deep sutures; last whorl dilated, with an angular periphery and a protracted aperture. Peristome continuous, expanded all round. Aperture rounded heart-shaped, with 5 teeth, 2 on the parietal wall, 2 on the outer wall, and 1 on the columella. Sculpture consisting only of oblique fine lines of growth. Umbilicus deep, widening below and surrounded by a basal keel. Colour light brownish. Max. dimensions: diameter 2.7; height 2, h. of aperture $1.1 \mathrm{~mm}$.

About 20 empty shells were collected. - 'The characteristics of the genus are given by Tryon (1884, Struct. and Syst. Conch.) as follows: shell convolute, conoidal, umbilicus open, last whorl free, protracted, turned upwards; aperture trumpet-like and dentate; peristome horizontal, expanded.s Moellendorff includes (1891, Proc. \%ool. Soc. London) 7 species in the genus, and to them are to be added: H. rochebruni Mabille (1857), 'Tonking, H. roebeleni, pusillum, edenlulum MoelcexdorfF (1894), Philippines, H. everetti Smin (1896), Kalao, IsI., H. sibuyanicum, polyodon, quadrasi Moellexdorff (1896), Philippines, H. fruhslorferi Moellendorff (1897), Java, $H$. dohertyi Fultox (1899), Tenimber Isl., H. hangchowensis Pilsiry (1908), China, and 11. insulanum Pusbry (1910), Japan. The earlier known forms are distributed in Further India. The genus is lacking on the Great Sunda Islands, as pointed out by Cooks (1894, Cambridge Natural History, Mollusca). The more interesting is the fact that one species is now recorded from Queensland, a circumstance which is a further proof of the former connection of Australia and New Guinea, the only possible way of its invasion. No forms of Hypselostoma are yet known from $\mathrm{N}$. Guinea, it is true, but they will certainly become known, either living or fossil, when the fauna is better explored (cf. Microphyura microdiscus).

Aphanoconia extincta n. sp. (Pl. 3, figs. 110-112). Shell depressed conical, somewhat shiny, with slightly convex base, and little convex whorls, the last one obtusely carinated, slowly descending in front. Sculpture consisting of fine regular lines of growth crossed by microscopic oblique rugae, and rather coarse spiral lirae, of which $4-6$ on the upper side of the last whorl and $3-5$ on the penultimate whorl, the lirae stretching up to the smooth apical whorl. Aperture oblique, rounded triangular, peristome thin, hardly expanded, under lip with a tooth-like projection at the end of the excavated columella. Basal callus faintly granular, thick and distinctly bounded below, thinning and less distinctly limited upwards. Colour grayish white, with traces of one subsutural and of one angular white band. Mlax. dimensions: diameter 5.2 ; height 3 ; h. of aperture 2 ; br. of ap. $2 \mathrm{~mm}$; whorls $4^{3 / 4}$.

The strong spiral seulpture of this shell proves that it belongs to the group Sculpla of Aphanoconia (ef. WAGNER 1911), among which it comes nearest to $A$. kalaoensis E. A. Surrir, from Kalao Island, and A. submucronata MöLlendorfF from German New Guinea. It is of interest that the affinities of the present form are to 
be searched for in the districts named and not among the recent Helicinidae of the Australian continent, belonging to Aphanoconia, subg. Sphacroconia, or to Palacohelicina, subg. Ceratopoma (cf. WAGNER 1911).

Omphalotropis minuta n. sp. (Pl. 3, figs. 113, 114). Shell turreted, with convex, tumid whorls, coarsely spirally lirated and with irregular faint lines of growth, the apex $(1-]^{1 / 2}$ whorls) smooth, bulbiform; base somewhat smooth, with fainter spiral lines; aperture somewhat oblique, ovate, peristome simple, rather thick, columellar margin oblique, straight or a little convex, callous, so as to nearly cover the umbilicus; lips connected by a rather thick parietal callus. Umbilicus narrowly contracted, furrow-shaped, bordered by a nearly obsolete umbilical keel. Colour light grayish, aperture with a feeble tint of orange within. Max. dimensions: height 2.5 ; br. 1.8 ; 1. of aperture 1 ; br. of ap. $1 \mathrm{~mm}$; whorls $4 \frac{1}{2}$.

This species, of which 8 specimens of various sizes were collected, seems to belong to the group Stenotropis, on account of its nearly obsolete umbilical keel (cf. Kobelt 1906). In its lirate sculpture it resembles O. conella Sykes (1902, Proc. Mal. Soc. London) from New Hebrides, but it differs from this and other species of the genus in lacking a peripheral carina on the last whorl, in having a less number of whorls, and in its small size. No operculum was found. The occurrence of this form of a chiefly Polynesian group in the caves of Chillagoe is very interesting. as no member of the genus lives nowadays on the continent of Australia. This locality (Australia) given by Pfeiffer for his O. malleata is doubtful (cf. Kobelt 1906).

Microphyura microdiscus (BAVAY) (PI. 3, figs. 115-118). Shell depressed, orbicular and almost discoidal, with slightly convex spire and a broadly excavated umbilicus, occupying a third of the shell diameter. Whorls narrow, the last one shouldered, slightly bent down in front. Aperture somewhat contracted, narrowly lunate with continuous peristome, thickened all round; outer lip reflected, inner lip projecting as a transversal plate from body whorl. Parietal wall with 2 teeth, the upper one longer, terminating before reaching the inner lip; outer wall smooth inwardly. Surface microscopically sculptured with close spiral lines, most distinct on the peripheral part of the base, and obsolete lines of growth; umbilicus smooth within. Colour yellowish white. Max. dimensions: diameter 1.7 ; height 0.0 ; h. of aperture $0.4 \mathrm{~mm}$. Whorls $3 \frac{1}{3}$.

About ten shells were collected, all of them being of a subfossil appearance and covered with earth. They agree completely with the figures and descriptions given by $\mathrm{BAv}_{\mathrm{A}}$ (1908, p. 283, pl. XIV, fig. 10). BAvAY, who does not, however, mention the microscopic sculpture, has referred the species to Polygyra, but in consideration of the geographical distribution of this genus, which is exclusively North American, I include this species in the genus Microphyna AxcEx, since it has a striking resemblance, on the one hand, to $M$. (Diplomphalus) microphis Cross: from New Caledonia, on the other, to $M I$. hemiclausa 'I'ATE (I896), from Central Australia. From both, however, it differs in possessing teeth on the parietal wall 
- at least none are described in the former. On the other hand no recent forms show so close agreement with it as rather this genus. The type was found at Humboldt Bay, Dutch New Guinea. That the present species is really identical with BAvaY's species is beyond all doubt. I am indebted to Professor A. WICHMANN of Utrecht for a comparison of one of the present specimens with the types of Bavay. At his kind request it was compared by Dr. C. A. VaN DER WILLIGEN in Leiden, who gave this opinion as to its identity: „Beim Vergleich des Exemplares des Herrn Dr. OdHNer mit der Polygyra microdiscus von der Humboldt Bai stellte sich eine vollkommene Übereinstimmung heraus. Bei beiden kommt die Spirallinie vor, die jedoch nur bei mikroskopischer Untersuchung zu gewahren ist, genau wie von Dr. ODIINER angegeben wurde.s

The occurrence of one and the same species in a subfossil state at these two separate localities, the one situated in New Guinea and the other in North Queensland, is a fact of considerable interest, as it offers the best thinkable proof of the theory of a land bridge between the two countries in a geological period immediately preceding the present time. A careful, scientific investigation of the caves at Chillagoe will certainly reveal many other facts of importance as to our knowledge of the zoo-geography of Australia.

Besides the above-named species, the collection of fossil shells from the Chillagoe caves contained 2 fragmentary specimens of an Endodonta (Churopa), one somewhat defective shell of a $P u p a$, seemingly not agreeing with any of the known Australian species, and with 7 teeth in its mouth, and, lastly, a new specics of Pseudopeas (Eremopeas), very like $P$. interioris 'ТАTE in sculpture but differing in shape, intermediate between this and $P$. tuclieri. It measured $7.5 \mathrm{~mm}$ in length, $2 \mathrm{~mm}$ in breadth at 9 whorls. The apical whorls exhibited very faint traces of the peculiar sculpture described by Pilsiry (1906, Man. of Conch., Vol. 18). The recent species of the genus are viviparous, and it is therefore of interest that the present specimen, in breaking off short during its treatment for examination, delivered a small egg of 1 $\mathrm{mm}$ in length, of ovate shape and somewhat compressed from two opposite sides. Though this fact may not necessarily indicate an oxiparous nature, it may, however, be noted as a fact worthy of the attention of future investigators. 


\section{List of Works referred to.}

1868. Cox, J. C., A Monograph of Australian Land Shells. Sydney.

1876. Bergi; R. Malacologische Untersuchungen. H. X. Semper, Reisen im Archipel der Philippinen. T. II. Bd 2. Wiesbaden.

1879. Troscuel, F. H., Das Gebiss der Schnecken. Bd 2, Lief, 6, Berlin.

1879. Thros, G. W., Manual of Conchology, Vol. 1. Cephalopoda. Philadelphia.

1880. v. Martens, E., Beiträge zur Meeresfauna d. Insel Mauritius u. d. Seychellen. Mollusken. Berlin.

1880. Tryos, G. W., Manual of Conchology, Vol. 2.

1881. - - I. c., Yol. 3.

1882. - - l. c., Vol. 4 .

1882. Dunker, G.. Index Moll. Maris Japonici. Cassellis Cattorum.

1883. Surt, E. A., On the Fresh-water Shells of Australia. Journ. Limn. Soc. London. Vol. XVI.

1883. Tryos, G. W., Manual of Conchology, Vol. 5.

1884. Godwin-Austen, H. H., Land and Fresh-water Mollusca of India I. London 1882-1889.

188t. Smitr, E. A., Mollusea. Rep. on the Zool. Coll. made...during the Voy. of H. M. S. \$Alert». Lonilon.

1884. TRyon, G. W., Manual of Conchology, Vol. 6.

1885. Brazier. J., Critical List of Mollusca from North-west Coast of Australia. Proc. Linn. Soc. N. S. Wales. Vol. 9.

1885. Cooke, A. H., Rep. on the Test. Moll. obtained... in the Gulf of Suez... 1869. By Rob. Mac Andrew. Republished with Add. and Corr. Part I-III. Anu. Mag. Nat. Hist. Ser. 5, Vol. 15, 16.

1885. Hutron, F. W. Revision of the recent Lamellibranchia of New Zealand. Proc. Liun. Soc. N. S. Wales, Vol. IX.

1885. Suith, E. A. I amellibranchiata. Rep, "Challenger», Vol. XIII.

1885. Trrov, G. W., Manual of Conchology, Vol. 7.

1886. Brazier, J., Synonymy of and Remarks upon the Specific Niames and Authorities of four Species of Australian Marine Shells. Proc. Limn. Soc. N. S. Wales, Vol. 10.

1886. Cooke, A. H., Rep. on the Test. Moll. obtained... in the Gulf of Suez... 1869. By Rob. Mac Andrew. Republished with Add. and Corr. Part V. Ann. Mag. Nat. Hist. Ser. 5, Vol. 18.

1886. Tisyon, G. W., Manual of Conchology, Vol. 8.

1886. Watson, R. B., Scaphopoda and Gasteropoda. Rep. schallenger». Vol. XV.

1887. Tryon, G. W., Manual of Conchology, Vol. 9.

1889. Hedley, Cir, List of Mollusca. Savidele-Kent, Preliminary observations on a Nat. Hist. Coll. Proc. Roy. Soc. Queensland, Vol. VI.

1889. —- On Aneitea graefiei and its Allies. I. c., Vol. V.

1889 _ - A list of land shells recorded from Queensland. $I_{d}$. c., Vol. V.

1889. V. Martens, E., I ist of Shells of Mergui and its Archipelago. Joum. Linn. Soc. Zool. Vol. 21. I.ondon.

1889. Pir.sbrr, H. A., Manual of Conchology, Vol. 11.

1889. Snxorn, II., Über einige Vaginula-Arten. Zool. Anzeiger Noo. 319.

1889. Tate, R., New Species of Marine Mollusca from S. Australia and Victoria. Trans. Roy Soc. S. Austr. Vol. X.

1890. Herdman, W. A., On the Structure and Functions of the Cerata or lorsal Papilla in some Nudibranchiate Mrollusca. Quart. Journ. Mier. Sci. Bd 31.

1890. Pilsbry, H. A., Manual of Conchology, Vol. 12. 
1891. IEdere, Chr, Australian slugs. Nautilus, Vol. V.

1891. - - If Mussox, C. '1'., On a collection of Land and Fresh-water Shells from Queensland. Proc. Linn. Soc. N. S. Wales, Yol. 6.

1891. Mussok, C. T., On the naturalised Forms of Land and Fresh-water Mollusca in Australia. I'roc. Linn. Soc. N. S. Wales, Vol. 5.

1891. Siмrotu, H., Über das Vaginulidengenus Atopos n. g. Zeitschr. f. wiss. Zool. Bu 52.

1891. - - Ueber einige Vagimula-Arten. Zool. Anzeiger 5.

1891. Sзитн, L. A., On a Coll, of Marine Shells from Aden. Proc. Zool. Soc. I.ondon.

1892. Bedval, W. T., Land and Fresh-water Mollusca. Trans. Roy. S. Australia, Vol. XVI. Part. 1. Adelaide.

1892. Brazler, J., Synonymy of and Remarks on old-described Australian Mollusca with Yotes on their Distribution. Proc. Linn. Soc. N. S. Wales, Vol. VIII.

1892. Cur, J. C., Descriptions of some new Species of P'ulmonate MIoll. from Australia and Solomon Is. Proc. Linn. Soc. N. S. Wales, Vol. 6.

1892. Heder, CH., Remarlis on Australian Slugs. Ann. Mag. Nat. Hist. IX.

1893. - - On Parmacochlea fischeri, Ssutu, Macleay Memorial Vol., Linn. Soc. N. S. Wales.

1893. Pilserr, I. A., Manual of Conchology, Vol. 15.

1893. PLATE, L., Studien uber opisthopneumone Lungenschnecken II. Zool. Jahrb. Anat. u. Ontogenie, Bd 7. II. 1 .

1893. Woodward, M. F., On the auatomy of Ephippodonta Macdougalli Tate. Proc. Malac. Soc. London, Vol. 1, No. 1.

1894. Hedex, Ch., The Land Molluscan Fauna of British New Guinea. Proc. Linn. Soc. N. S. Wales, Vol. 8.

189. Sarti, E. A., On the Land-shells of Western Australia. Proc. Malac. Soc. London, Yol. 1, No. 3.

1895. BERNaRd, F.g Sur le développement et la morphologie de la coquille chez les Lamellibranches. I'remière note. Bull. Soc. Géol. de France, sér. III, t. 23.

1895. Hecht, E., Contribution à l'étude des Nudibranches. Mém. Soc. Zool. de France, Tome VIII.

1895. Hedery, Cir., Notes on West-Australian Land-shells. Yroc. Malac. Soc. London, Yol. 1, No. 6.

1895. Rochebrune, A. T. DE, Monographie des formes jusqu'ici connues, appartenant au genre Ceratosoma. Nouv. Areh. Mus, d'Hist. Nat. Sér. 3. I'aris.

1896. Tate, R., Mollusca. Rep. on the Work of the Horn Scientific Exped. to Central Australia. Part II Zoology. Melbourne.

1897. IEdery, CH., Descriptions of New Land Shells. Rec. Austral. Mus. Yol. 3, No. 2.

1899. - - The Mollusca of Funafuti. Part I Gastropoda. Mem. Austral. Mus. III. Part. 7.

1899. Melvili, J. C., \& Standen, R, Report on the Mollusca obtained during the first exped. of l'rof. $\Lambda$. C. Haddon to Torres Straits. Journ. Linn. Soc. London, Vol. 27.

1899. Pritchard, G. B., \& Gathiff, J. II., Catalogue of the Marine Shells of Victoria. Part. I. Proc. Roy. Soc. Victoria. Yol. XI.

1899. Sarasin, P.\& F., Die Land-Mollusken von Celebes. Materialien zur Naturgeschichte der Insel Celebes. Bd II. Wiesbaden.

1900. Hedeey, Ch., Studies on Australian MIollusca, l'art II. Proc. Linn. Soc. N. S. W., Yol. 25.

i900. PfEIfFEn, IV., Die Gattung Triboniophorus. Zool. Jahrb. Anat. u. Ontogenie. 13d 13. Jena.

1900. Pritcinard, G. B., \& Gatiffe, J. II., Catalogue of the Marine Shells of Victoria, Part IV. Proc. lioy. Soc. Victoria, Yol. XIII.

1900. Surson, Cr. T., Synopsis of the Naiades or pearly fresh-water mussels, l'roc. U. S. Nat. Mus., Vol. 22.

1901. Hedeey, Cri, A Revision of the Types of the Marine Shells of the Chevert Exped. Records Austral. Mus., Vol. 4. No. 3.

1901. - - Studies on Australian Mollusca, I’art V. Proc. Linn. Soc. N. S. Wales, Yol. 26.

1901. Jameson, II. L., On the Identity and I)istribution of the Mother-of-Pearl Oysters, witl a Revision of the Subgenus Margaritifera. Proc. Zool. Soc. I.ondon. Vol. 1.

1901. Melvill, J. C., \& Standen, R.. The Mollusca of the Persian Gulf, Gulf of Oman and Arabian Sea. Proc. Zool. Soc., Vol. II.

1901. V. MLoLLENonfF, O. F., Laudmollusken. Ergănzungen u. Berichtigungen. SEMPER's Reisen im Archipel d. Philippinen. Wiss. Kes. Bd 8, 1898-1904.

1901. Pritchaid. G. B. \& Gathiff, J. II., Catalogue of the Marine Shells of Victoria, Part V. Proc. Roy. Soc. Victoria, Vol, 14.

1901. Tate, R., \& MaY, W. L., A Revised Census of the Marine Mollusca of Tasmania. I'roc. Linn. Soc. N. S. Wales, Vol. 26.

1901. Varssiere, $\Lambda$., Recherches zoologinues et anatomiques sur les Mollusques Opisthobranches du Golfe de Marseille. P. III. Ann. Mus. Marseille VI.

1902. Elot, Sir Charles, On some Nudibranchs from Zanzibar, Proc. Zool. Soc. London.

1903. - - Nudibranchia. Fauna and Geography of the Maldive and Laccadive Archipelagoes, Vol. II, I'art I. 
1903. Hedlex, Ca., Studies on Australian Mollusca. Part. 7. Proc. Linn. Soc. N. S. Wales, Vol. 27.

1903. V. MLARTEN, Die beschalten Gastropoden der deutschen Tiefsee-Lxpcdition 1898-99. Systematisch-geogr. Teil. Wiss. Ergebnisse d. Dentsch. Tiefsee-Exp. (Valdivia), Bd 7. Jena.

1903. Surti, E. A., Marine Mollusca. Fauna and Geograplyy of the Maldive and Laccadive Archipelagoes, Vol. II, Part. II.

1903. Varssière, A., Recherches sur les Moll. Opisthobranches du Golfe de Marseille. Supplément. Ann. Mus. d'hist. nat. de Marseille. Zool. Tome VIII.

1904. Smiti, E. A., On Mollusca from the Bay of Bengal and the Arabian Sea. Nat. Hist. Notes from H. M. Indian Marine Survey Steamer \$Investigator». Ann. Mag. Nat. Ilist. Ser. 7, Vol. 13.

1904. Pritcilakd, G. B., \& Gatiff, J. H., Catalogue of the Marine Shells of Victoria, Part VIII. Proc. Roy. Soc. Victoria, Vol. 17.

1905. Antrons, $\mathrm{R}$, Intluence de la fixation pleurothétique sur la morphologie des Mollusques acéphlıales dimyaires. Ann. Sciences Naturelles. Zool. sér. 9, t. 1. P’aris.

1905. BAsEDow, H., \& HEDLEY, CH., S. Australian Nudibranclis and an Enumeration of the known Australian Species. 1R. Soc. S. Austr. Trans. and P'roc., Vol. 29.

1905. Bergi, R., Die Opisthobranchiata der Siboga-Expedition. Siboga Exp. Livr. XXV. Leiden.

1905. Hedeex, CH., Report on the Mollusca coll.... on the S. Australian Government Forth-West Exped. 1903. Trans. Roy. Soc. S. Australia, Vol. 29.

1906. Eliot, Sir Charles, On the Nudibranchs of Southern India and Ceylon... Proc. Zool. Soc. London, Vol. 45: 2.

1906. Kobelt, W., Synopsis der Pneumonopomen-Familie Realiidae. Nass. Ver. f. Naturk., Jahrb., Jahrg. 59. Wiesbaden.

1906. Sirm, E. A., On Mollusca from the Bay of Bengal and the Arabian Sea. Nat. Hist. Notes from H. M. Indian Marine Survey Steamer $\gg$ Investigator». Ann. Mag. Nat. Hist. Ser. 7, Vol. XVIII.

1907. Cúxot, L., L’origine des nématocystes des Eolidiens. Arch. de Zool. expér. et génér. IV Sér., Tome VI.

1907. Lavy, E., Révision des Arca vivants đu Museum d'Histoire naturelle de Paris, Journ. de Conchyliologie 55.

1907. Stantscinsskr, W., Zur Anatomie und Systematik der Gattung Oncidium. Zool. Jahrb. Syst. Bd 25.

1907. Srkes, E. R., On the Polyplacophora or Chitons. Rep. Mar. Biol. Sudanese Red Sea. Journ. Linn. Soc. Zool. Isondon. Bd 31.

1907. Verco, J. C., Notes on S. Australian Marine Mollusca with Descr. of New Species, Part VI. Adelaide. R. Soc. S. Austr. 'Trans. and Proc., Vol. 31.

1908. Bayay, A., Mollusques terrestres et fluviatiles. Nova Guinea. Rés. de l'expéd. scient. néerlandaise à la Nouvelle-Guinée. Vol. V. Zool. Leiden.

1905:. Hedlex, Ch., Studies on Australian Mollusca. Part X. Proc. Linn. Soc. N. S. Wales, Yol. 33.

$1908^{7}$. - - Mollusca from one hundred fathoms..., Tasmania. Records of Australian Museum, Vol. VII.

1908. Schepman, MI. M., Rhipidoglossa and Docoglossa. Siboga Exp. Livr. XXXIX.

19108. Verco, J. C., Notes on S. Australian Marine Mollusca with Descr. of New Species, Part IX. Adelaide, R. Soc. S. Austr. Trans, and Proc., Vol. 32.

19(19. Hedrex, CH., Mollusca from the Hope Islands, N. Queensland. Proc. Linn. Soc. N. S. Wales, Vol. 34.

1909. LYNGE, H., Marine Lamellibranchiata. The Danish Exped. to Siam 1899-1900. Mém. de l'Acad. Roy. des Sciences et des Lettres de Danemark. 7 sér. t. Y. No. 3.

1909. Melvils, J. C., Rep. on the Marine Mollusca, obtained by Mir. J. Stanley Gardiner among the Islands of the Indian Ocean in 1905. Trans. Linn. Soc. London, Ser. 2, Vol. 13. Zool.

13019. Schepman, M. M., Tænioglossa and Ptenoglossa. Siboga Exp. Livr. XiliII.

1909. - - Gymnoglossa. L. c. Livr. XLVI.

1909. Surt, E. A., Totes on Voluta norrisii, V. piperita, V. sophia, and Description of a neav Species. Ann. Mag. Nat. Hist. Ser. 8. Vol. IV.

1909. THELE, J., Revision des Systems der Chitonen I. Zoologica H. 56. Stuttgart.

1909. Varssière, A., Sur une nouvelle famille d'Acolididés, les Madrellidés, et sur le nouveau genre Eliotia appartenant à cette famille. Comptes Rendus de l'Acad. des Sciences Paris, T. 149.

1910. Euot, Sir Chances, The British Nudbranchiate Mollusca (Alder \& Haxcock). Part VIII (Supplementary). London.

1910. Hedrex, Cir, Catalogue of the Marine Mollusca of Queensland. Rep. Austral. Ass. for Advancement of Science. Brisbane. Vol. XII.

1911. Pelsweer, P., Les Iamellibranches de l'Expéd. du Siboga. Partie Anatomique. Siboga-Lixped. Livr. LXI.

1911. Scueprax, M. M., Rachiglossa. Siboga Lxp. Livr. LVIII.

1911. Wagner, A., Die Familie der IIelicinidae, Martun \& Cnesintz, Conchylien-Cabinet, Nünberg.

1912. Dautzeriera, Cir., \& Bafay, A., Les Lamellibranches de l'Exped. du Siboga. Partie Systematique. I Pectinidés. Siboga-Exped. Livr. LXIII. 
1912. Hedrer, CH., On some Land Shells collected in Queensland. P'roc. Limn. Soc. N. S. Wales, Vol. 37.

1912. ODINER, N., Norphologische und phylogenetische Untersuchungen über die Nephridien der Lamellibranchien. Zeitschr. f. wiss. Zool. Bd 100.

1913. Greser, E., Über die Anatomie von Chama pellucida Broderur. Fauna Chilensis I3d 4, II. 2. Jena. 1913. Hedlex, CH., Studies on Australian Mollusca. Part X̌I. I'roc. Linn. Soc. N. S. Wales, Yol. 38.

1913. ScuEPMaN, II. M., I'ulmonata and Opisthobranchia 'Tectibranchiata. Siboga Exped. Livr. LAVI.

1913. - - Toxoglossa. Siboga Lxped. Livr. LXIV.

1913. Suter, II., Manual of the New Zealand Mollusca. Wellington, N. Z.

1914. Iredal, T, On some invalid Molluscan Generic Names. Proc. Malac. Soc. London, Vol. XI, Part III.

1915. Baktsci, P., Report on the Turton Collection of S. African Marine Mollusks ... Snithsonian Institution, U. S. Nat. II S. 13ull. 91. Washington.

1915. IIEder, CH., Studies on Australian Mollusca. Part XII. Proc. Linn. Soc. N. S. Wales, Yol. 39.

1916. - - A Preliminary Index of the Mollusea of Western Australia. Journ. Roy. Soc. West. Austr. Vol. I. Perth.

1917. - - Studies on Australian Mollusca. Part XIII. Proc. Linn. Soc. N. S. Wales, Vol. 41. 


\section{Index.}

abdita, Flammulina, Hedex . . . . . I’ag. Acavidae . . . . . . . . . . . . . . . 88 Achatinidae . . . . . . . . . . . . 88 Acmaea . . . . . . . . . . . . 9 aculeata, Crepidula, Gmets. . . . . . . 1 acuticostata, Nassa monile var, Moxtrallie adelaide, Ceratosoma, Basedor \& Hedeey agrestis, Limax, LINNÉ

albata, Pleurotoma, E. A. Surtit . . . . . . 57

albicosta, Modiola, Lamarch . . . . . . . . 19

albida, Chamostrea, Lararck . . . . . . . 5, 35

albus, Malleus, Lamarck . . . . . . . 8

Amalia . . . . . . . . 73

Ameria . . . . . . . . . . 74

Amphineura . . . . . . . . . 70

Ancillaria . . . . . . . . . . . 11, 56

Ancylus . . . . . . . . . . . . . 74

Ancitea . . . . . . . . . . . . . . 89

angasi, Unio, Sowerby . . . . . . . . . . 96

Angasia . . . . . . . . . . . . . . 70

Anomia . . . . . . . . 8, 14

Anomiidae . . . . . . . . . . . 14

anthropophagorum, Sitala, Hede $L^{\prime}$. . . . . . . 83

antiqua, Microcystis, n. sp. . . . . . . . 97

antiquata, Mactra, Spexgler . . . . . . . . . . 9

Aphanoconia . . . . . . . . 98

arborum, Limax, Bovchard-Chantereaux . . . . 73

Area . . . . . . . . 8, 21

architectonicus, Trochus, A. ADAus . . . . 9, 44

Arcidae

arctica, Saxicava, LINNÉ

. 21

34

aridorum, Chloritis, Cox

Artemis

aruanus, Megalatractus, Liske.

Asaphis

asperella, Cancellaria, LaMABCh

asperrimus, Pecten, Iauarck

aspersa, Cliama, ReEve

Atilia

Atopos

atratus, Euchelus, Greecix

attegia, Sitala, Godwis-Austes. attenuatum, Cerithium, PHILPri . .

Atys . . . . . . . . . . (i)

aurantiaca, Madrella, VAYssiere . . . . . . (i!)

aurifluus, Pectunculus, ReEve _. . . . . 2.2

auris dianae, Strombus, LinNé . . . . . . . 10

australasiae, Cymatium, P'ErriY. . . . . . . . 44

| australicus, Ancylus, T'AтE . . . . . . . . 74

australis, Atopos, HeYNEMANy . . . . . . . ! !

\&, Hipjonyx, Quor \& Gamard . . . . . 4 i;

, Hypselostoma, n. sp. . . . . . . . 1s

, Pecten, Sowerizy . . . . . . 11

, Plicatula, Lanarcr . . . . . . 15

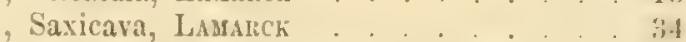

, Trivia, Lamarck . . . . . . . . . 5;

Austrochloritis . . . . . . . . . . mf

arellana, Arca imbricata var., LAMAack . . . 21

Avicula . . . 15, 17

Aviculidae . . . . . . . . . . . . . . . . .

axicornis, Murex, LamarcK . . . . . . . . 5.

badius, Capulus, Dunker ........ . . . . . . . .

barbata, Modiola, JaAarch . . . . . . . . . . .

bednalli, Trigonia margaritacea var., Verco . . . 2:3

berryi, Chione, Deshares . . . . . . . !

bicincta, Triphora, 11. sp. . . . . . . . . . 47

bicolor, Cancellaria, Hisds . . . . . . . 55

, Pinna, Chemsitz . . . . . . -

bicome, Ceratosoma, Brran . . . . . . . til

bilabiata, Chloritis, n. sp. . . . . . .

bilinguis, Pupina, Pferterer . . . . . . .

bilocularis, Septifer, IJNEE

bipartita, Ilalra, FÉressac . . . sc

() bipunctata, Trivia, n. sp. . . . . . . . . . . . .

11 biradiatum, Cardium, IBRUGrière . . . ב-

9 bonus-henricus, Ameria, ADars \& ANGAs . Tt

11 Bothriembryon . . . . . . . . . . . .

14 brevicaudatum, Ceratosoma, Abraliam . . . (i2

30 , Ceritlium attenuatum, n. var. . 47

51 brevispina, Murex, IAsarck ... 11,

90 brevispira, Isodora gibbosa, 11, var. . . (16)

9, 44 Buccinidae . . . .

83 | Inuccinum .

K. Sv. Vet. Akall. Handl. Band 52. X̃:0 16. 
Bulimulidae

Bulla

bullaceus, Helicarion, n. sp.

Byssoarca.

campbelli, Strombus, Griffith \& l'Jogeos

Cancellaria .

Cancellariidae

cancellata, Terebra, Quoy \& Gamard.

Cantharus

capillacea, Rhytida, Férussac

capitaneus, Conus, Liso'

Capulidae

Capulus.

Cardiidae

cardiiformis, Pectunculus, ANGAS

Cardita

Carditidae

Cardium

Cassis .

castanea, Thersites, n. sp.

caurica, Cypraea, Linsé

Cephalopoda

Ceratopoma

Ceratosoma

Cerithidea

Cerithiidae

Cerithiopsis

Cerithium

cervicornis, Murex, Lamarck

ceylanica, Cyrena, Cuennitz

Chama

chamaeleon, Nerita, LiNsé

Chamidae

Chamostrea

Chamostreidae

Charopa.

chemnitzi, Pinna, HakieY

Chione

Chloritis .

Chromodoris

cinerea, Oncis, n. sp.

cingulata, Ancillaria, Soweru

cingulifera, Turritella, Sowerby

Circe

clatlrata, Vanikoro, Recuuz

Clementia

clupeus, Emarginella, ADAMS

coerulescens, P'sammobia, Lamarck

colubrinus, Conus, IaAmarck

Columbella .

Columbellidae

columellaris, Jerebra, Hrwns

complanata, Arca, Chesrnitz

conella, Omphalotropis, Syкes

Coneuplecta

confusa, Rhytida, Pfeiffer

conica, Natica, Lamarck

Conidae

\begin{tabular}{|c|c|c|c|c|c|c|c|c|}
\hline & & & & & & & & - \\
\hline & 73 & onidea. & & & & & 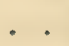 & $\because 0$ \\
\hline & 12 & consociata, Pleurotoma, E. A. Smi & ITU & - & . & . & & 57 \\
\hline & 77 & conspersa, Columbella, Gaskors . & & & . & & & \\
\hline & 21 & $\begin{array}{l}\text { Conus - Ceratosoma, n. sp. } \\
\text { corallinum, }\end{array}$ & & & . & . & 11. & \\
\hline 10. & 48 & $\gg$, Cerithium, Durresse & & & 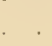 & . & & \\
\hline & $\therefore 5$ & Corbula . . . . . . . & . & . & & . & & 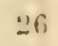 \\
\hline & isi & cornigerum, Ceratosoma (ADA3s) B & BERG & & & & & \\
\hline & (i) & ornucopia, l'seudochama, REEvE. & . & & & & & \\
\hline 11, & $\therefore 1$ & coronulata, Cassis, Sowerbr & & & & & & \\
\hline & $i t i$ & AMARCh & & & . & & - & \\
\hline & 11 & $\mathrm{a}, \mathrm{Fl}$ & & . & & & & \\
\hline & 46 & Dolium, MENKE. & & . & & . & - & \\
\hline & 47 & ia . . . . & & . & & & & \\
\hline & 27 & Craspedochiton . & & . & - & . & - & \\
\hline & 22 & orbula, Ilsos . . . . . & & 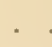 & . . & . & . & \\
\hline & 24 & ingulata, Mangilia, Scheryan & N . & . & . & . & 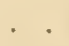 & \\
\hline & 24 & a, Cardita, IaAMARCK . & & 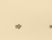 & . & & & 24 \\
\hline 4 , & 27 & a, Trigonia uniophora, & & & . & & & $2: 3$ \\
\hline & 11 & . . . . . & & & & . & & \\
\hline & 87 & Cypraea, Liswé . & & & . & . & & \\
\hline & 11 & l'seudochama, Lamarek . & - . & . & . & . & • & \\
\hline & 70 & . . . . . & & & & & & \\
\hline & 9 & ithiopsis, ANGas . & . . & - & . & . & & 7 \\
\hline & (i) & .... & - . & 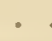 & & . & & (3) \\
\hline & 111 & olaria, (DUNKER) I & REE & & & & & \\
\hline & .17 & E.... & & & . & & & 15 \\
\hline & 47 & ulina, n. sp. & & S & . & & . & $t$ \\
\hline 10 , & 47 & E... & 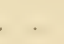 & 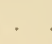 & & . & & $\therefore$ \\
\hline 11 , & $5 \overline{5}$ & GouLd & & . & . & & . & 211 \\
\hline . & 916 & gyra, Grar & . . & . & . . & & & \\
\hline & .2 & rginella, (Audo1s) Isse & & . & & & . & \\
\hline 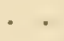 & 111 & DRBIGNY . & & . & & & . & $7(1$ \\
\hline & $\ddot{2}$ & , liellya, Desinayes & & . & & $x^{2}$ & & 24 \\
\hline & 3.1 & . . . . . . & . . & & . . & . & & . \\
\hline & 34 & , Planispira, LE GuIld & LOU & & & . & & 5 \\
\hline 72, & 8.5 & . . . . . . . & . . & & & & & .19 \\
\hline & 7 & . . . . & . . & & . . & . & 11, & : \\
\hline 26 . & 71 & dae . & • & . & . & . & & $\therefore 1$ \\
\hline$\cdot$ & $8:$ & 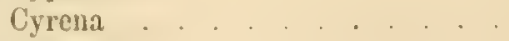 & . & . & & & . & \\
\hline 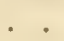 & (i; & lae & • & . & . . & . & . & (i) \\
\hline & $\pi$ & . . . & & 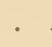 & . & . & & in \\
\hline & 11 & Cytherea. . . . . & . & & & 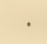 & & \\
\hline 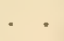 & 4 & & & & & & & \\
\hline 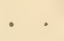 & 27 & Iidea, IINNÉ . & & & & . & & \\
\hline & $46 ;$ & Arca, Sowerar & & & & & & 21 \\
\hline & 9 & Asaphis, LINNÉ & . & . & & & & $!$ \\
\hline & $4:$ & Planispira, Hedley. & . & & & • & & 17 \\
\hline & $!$ & 年 & . & . & & & . & 45 \\
\hline • & $1: 2$ & , Delphinula, I_INкÉ . & & . & & . & . & 45 \\
\hline & $\therefore$ & inella, livitos & & & . & . & $\cdot$ & 7, \\
\hline & i) & Perry . - & - & & & & & (1) \\
\hline & $\vdots !$ & hlamys suturalis, & var. & & & & & $\mathrm{C}$ \\
\hline & 21 & a, Srexgiser . . & & . & & & & \\
\hline & $! !$ & diadema, Melo, LaMarck & & - & & - & & 12 \\
\hline & -1 & s, l'ecten, n. sp. & • & 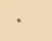 & & & & 1,5 \\
\hline & 7 & . . . . . . & . & & & . & & 71 \\
\hline & I & $0^{\circ} \cdot 0^{\circ}$ & . & - & & & & !!! \\
\hline & & lumbella, Greus . & & & & & & $5 \cdot 2$ \\
\hline
\end{tabular}


distorta, Delphiuula, LinNé

divaricata, Arca, Sowerby

Dolium

Doridopsis

Drillia

dringi, Pecten, ReEr

duclosi, Oliva, lieeve

duplicata, Terebra, Lissé.

durvillii, Xanthomelon, Hombrox \& Jaceursot

churnea, MIucronalia, Deshayes

echinata, Clıana, Broderip

Echinochama.

echinus, Crepidula, Broderip

Elasmias

Electroma

elegans, Nassa, Kiexer .

Eliotia

elongatum, Cardium, Bruguiere

elyros, Anomia, Gray

Emarginella

Emarginula

Endodonta.

Endodontidae

Ephippodonta

Eremopeas .

errones, Cypraea, LINNÉ

Erycinidae . . .

esontropia, Cypraea cribraria var., liefwe

essingtonensis, Paludina, Frauenfeld , Planorbis, E. A. Sutu

eucharis, Elasmias, Brazier.

Euchelus

Eulima

Eulimidae

eximia, Terebra, Drsuayes

extincta, Aphanoconia, n. sp.

faba, Oliva, Martat .

falconeri, Panda, Reeve

Fasciolariidae

fenestratus, Trochus, GMELIN

ferruginosa, Madrella, Alder if HArcuch

festa, Turricula, REeve .

fibula, Chama, ReEve

filosa, Natica, Sowerby

fimbriata, Chama, ReEr

I'erna, ReEve

fischeri, Parmacochlea, E. A. Surti

Fissurellidae

Flammulina

foliacea, Chione, Philippi.

forsteriana, Hadra, Pfeiffer .

foveolatum, Cardium, Sowerby

fragilis, Lima, Cirmisitz

fraseri, IIadra, Grat . . . . . . . . . . s

fulva, Microcystis, n. sp............ is

fulvicostatus, Pecten, ADAMS \& REEvE.

fumosa, Tritonidea, DILıwr

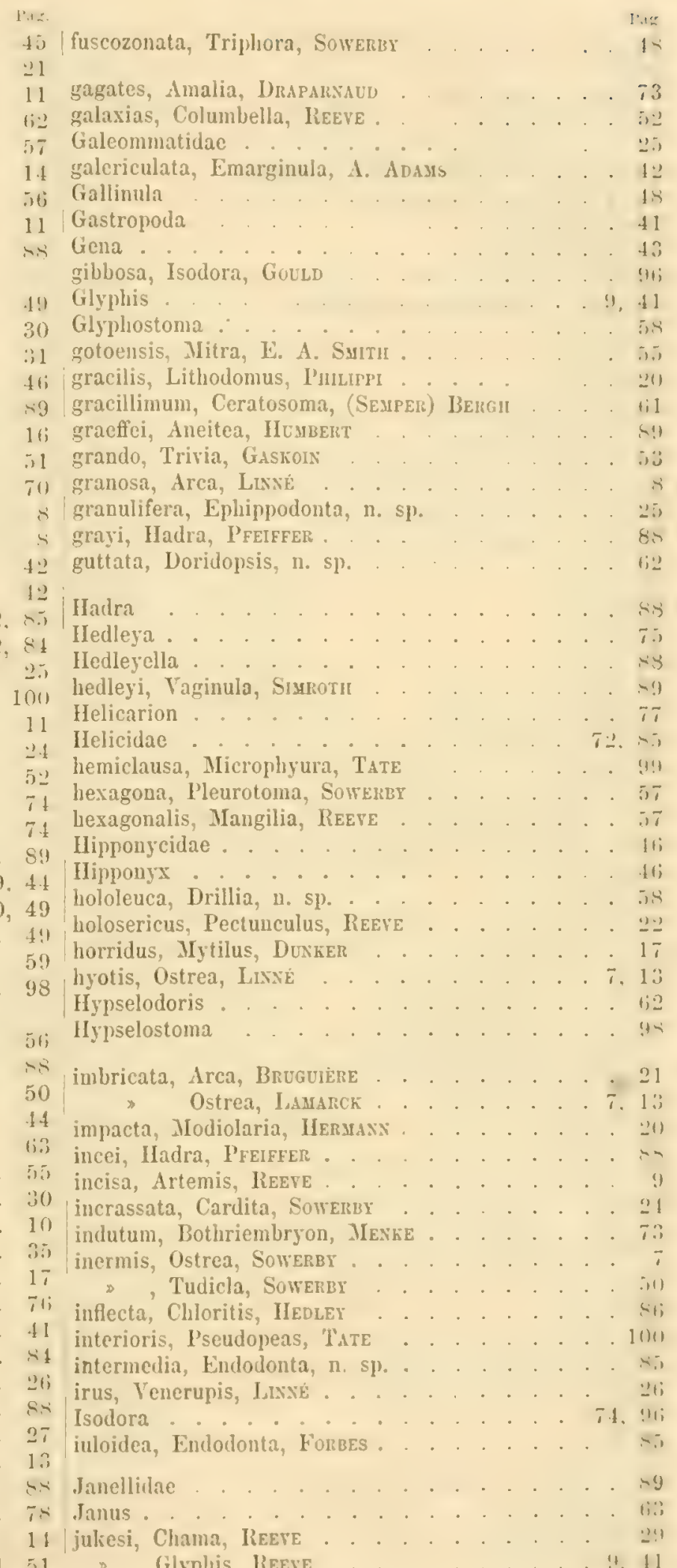


kalaoensis, Aphanoconia, k. $\Lambda$. Surti . . . . 9 líellya kraussi, Mytilus, ReEve

kreffti, Microcystis, Cox

labio, Monodonta, Liswé .

laciniata, Delphinula, Lasanck

Iavevicardium

Lamellibranchia .

lapicida, Naranio, Chesnitz

laqueatus, Craspedochiton, Soweris

Larina

laticostata, Chione, n. sp.

Latirus

lazarus, Chama, LIxมE .

lentiginosa, Oliva, ReEve

leptogramma, Rhagada, PFeiffer

Leptopoma .

leydigi, Vaginula, Siмnотн

liberiensis, Craspedochiton, 'Thele

Lima .

Limacidae

I imax

I.imidae .

Limnaeidae

Limopsis

lineata, Nerita, Linne

lineolata, Columbella, P'EASE.

I ithodomus

livida, Nassa, GraY

¿, Terebra, ReEve

lixi, Ceratosoma, Rochebruse

I. onchaeus .

Iucina

Lucinidae

Iutea, Cypraea, Groxovius.

lyratum, Cardium, Sowerbi

macdougalli, Ephippodonta, Tate

macgillivrayi, Papuina, Forbes.

macleayi, Hedleya, Cox

Macrocallista.

Macrochlamys

macrophylla, Venerupis, Deshayes

macropus, Octopus, Iisso

Mactra

maculata, Byssoarca, Soweruy

> Turcica, Brazier . . . . . . . 15

Madrella . . . . . . . . . . . 63

Madrellidae . . . . . . . . . . . T0

madreporarum, Pecten, PEтіт . . . . . . . 15

malleata, Omphalotropis, PFEIFFer . . . . . . 99

Mallens . . . . . . . . . . . . . $\$ 17$

MIamma . . . . . . . . . . . T

Mangilia ............ . . 57,58

margaritacea, Trigonia, Ldмакск . . . . . . . 23

Margaritifera . . . . . . . . 8, 15

margaritifera, Pteria, Linvé . . . . . . . . 15

marginata, Ancillaria, IAMARCK as.

marginata, Trevelyana, n. sp. . . . . . . . . . (i2

Marginella . . . . . . . . . . . ji

Marginellidac . . . . . . . . . . . . . . 5li

marmorata, Cardita, ReEve . . . . . . . 24

Microcystis, Cox . . . . . . . T4

!) marmorea, Cerithiopsis crocea, u. var. . . . . . 17

45 martinii, Lulima, A. ADAMS . . . . . 10, 49

27 martensi, Oncis, Plate. . . . . . . . . . 73

13 maxima, P'teria, Jaseson . . . . . . . . \&, 15

27 Megalatractus . . . . . . . . . 11

71) Melo .............. . 12

96 membranaceus, Octopus, Qcor \& Garsard - 12, 70

26 IIeta . . . . . . . . . . . 引l

$50)$ microdiscus, Microphyura, BayaY . . . . . . 99

28 Microcystis . . . . . . . 77, 97

if microphis, Microphyura (Diplomplualus), Crosse . . $9 !$

72 Mlicrophyura ............. . 9!

(5) minor, Gena strigosa, 11. var. . . . . . . . 4:3

(9) minuta, Omplalotropis, n. sp........... !!

T0 miranda, Modiolaria, E. A. Surı . . . . . . . 20

13 Mitra . . . . . . . . . . . . 54

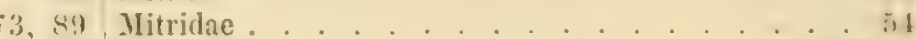

., M Mitrella . . . . . . . . . . . .

13 möbiusi, Craspedochiton, THiele . . . . . . . . T(1

96 Modiola . . . . . . . . . . . . . 1!

3.2 Modiolaria . . . . . . . . . . . . 201

11) moleculina, Columbella, Duclos . . . . . . . 5:

5.2 monile, Nassa, Kienel . . . . . . . . . . . 11

() monilifera, Ancillaria, Reeve ........... . . il

51 monodon, Murex, ReEve . . . . . . . . 11

(i) Monodonta . . . . . . . . . . !

61 morus, Cerithium, IaAmarck . . . . . . 10

49 Iucronalia . . . . . . . . . . . 4!

21 mülılfeldtiana, Pedinogyra cunninghami var.. PFEIffer \&

24 multispinosum, Cardium, ReEve . . . . . . !

53 multisquamosa, Chama, Reere . . . . . . . 2!!

27 multistriata, Limopsis, Fonski̊L . . . . . . . . 를

Yurex . . . . . . . . 11, 5i

Inuricilae . . . . . . . . . . 55

\$9 musivum, Cerithium, IIosmbon \& Jacquinot . . 111

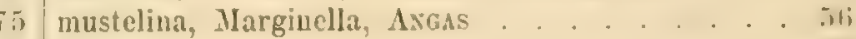

27 Myidac . . . . . . . . . . .

(1) Myochama . . . . . . . . . . . . :36

26 mysticus, Euchelus, PILsirix . . . . . . . . . . 14

70 Mytilidae . . . . . . . . . 17

I) mytiloides, Ostrea, Lamarch . . . . . . . . . . 13

Mytilus . . . . . . . . . 17

Naninidae . . . . . . . . . . . . 6

Naranio . . . . . . . . . . . . . . .

Nassa . . . . . . . . . . 11, 11

Nassidae . . . . . . . . . . . 51

Natica . . . . . . . . . 41,71

Naticidac . . . . . . . . . . . . 46

navicularis, Arca, Bruguene . . . . . . . . 21

Neotrigonia . . . . . . . . . 2?

Nerita . . . . . . . 111

newcombi, Isodora, A DaMS \& AxGas . . . . 74

56 nicobaricus, Mytilus, Cheanit . . . . . . . 18 
aiger, Latirus, 11. sp. . . . . . . . . . . . . 50

$»$, Lithodomus, D'OrBigNY . . . . . . . . . 21

niloticus, Trochus, LinnĖ . . . . . . . . . . 9

nigra, Pinna, Chensitz . . . . . . . . . . 7

norrisii, Voluta, Sowerry . . . . . . . . . 12

novaehollandiae, Thersites, Gray

$$
\gg \quad \text { Vermetus, Rousseau }
$$

Nudibranchia . . . . . . . . . 60

nympha, Mitra, ReEve . . . . . . . . 54

obliquata, Chama, Reeve .

oblita, Voluta, E. A. Surt . . . . . . 12

obscura, Marginella, REEvE . . . . . . . . 57

ochrostoma, Ricinula, Bhanvilue...... . 56

Octopus . . . . . . . . . . 12,70

olearium, Dolium, Iabrarck ........ . 11

Oliva , Triton

Olividae . . . . . . . . . . . 56

omaria, Conus, Hwass . . . . . . . . 1.

Omphalotropis . . . . . . . . . . . . 99

Oncididae . . . . . . . . . . . . . . . 73

Oncis . . . . . . . . . . . 73

Opisthobranchia . . . . . . . . . . 60

orbicularis, Pectunculus, ANgas

ordensis, Ostrea, Saville-Kent .

oryza, Trivia, LamancK .

ostracea, Tellina, Hanley

Ostrea

Ostreidae

Ovula .

pachystyla, Xanthomelon, PFeiffer

pacificus, Strombus, Swainson

Palacohelicina

palmiferus, Murex, Soweriy

Paludina .

Paludinidae

palustris, Potamides, LiNnE:

Panda

Paphia

Papuina .

papyracea, Clementia, GraY

papyraceum, Cardium, Chennitz

Papyridea

Parmacochlea .

participes, Nassa, Hedley

patiens, Cerithium morus var., Bayue

I'atro.

P'ecten

l'ectinidae

l'ectunculus

P'edinogyra

pellis-phocae, Chama, ReEve

pellucida, Chama, Brodelup'

lerna .

peronii, Chione, Lamarck .

pertusa, Terebra, Bori. petholatus, l'urbo, LiNsé

Petricolidae

Phacoides . . . . . . . . .

philippinarum, Columbella, Recuvz ........ 5

, Marginclla, Redfield . . . 51;

, Modiola, Haktex . . . . . 8, 1!

pholadis, Saxicava, LINNÉ . . . . . . . . . 3.t

l'hos . . . . . . . . . . . . . .

Physa . . . . . . . . . 74

Pinna . . . . . . . . . 7

placenta, Placuna, Linsé . . . . . . 71

Placuna . . . . . . . . . . 71

plana, Circe, п. sp. . . . . . . . . . . . 27

planata, Chama, ReEve . . . . . . . . 30

Planaxis . . . . . . . 11

Planispira . . . . . . . . . 85, 97

Planorbis . . . . . . . . . . .

planulata, Emarginelia, Adars . . . . . 4. 42

planulatus, Sigaretus, Recluz . . . . . . 10

Pleurotoma ........ . 57

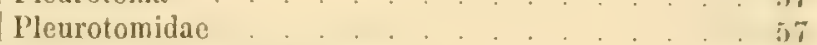

plicata, Arca, Chemitz . . . . . . . 21

I'licatula ............. 15

plicifera, Chamostrea, n. sp. . . . . . . 31

Plocamotis . . . . . . . . . $4:$

plumbea, Natica, Lasarck . . . . . . . . . .

plumescens, Modiola, Dunker . . . . 8, 19, 20

polita, Nerita, LuNNÉ . . . . . . . . 10

Polygyra . . . . . . . . . . 99

polyomma, Ceratosoma, Berah . . . . . . . (il

pomum, Xanthomelon, PfeIffer . . . . . . . 88

ponderosa, Siliquaria, Mörси . . . . . . . 10

porcatus, Turbo, ReEve. . . . . . . . . o

porosa, Cliama, Clessin . . . . . . . . . 30

porphyrites, Turbo, MARTYN . . . . . . . . 9

porteri, Chloritis, Cox . . . . . . . . . . 7

5 Potamides ......... 10

$74 \mid$ praehadia, Planispira, n. sp. . . . . . . 97

74, 96 P'risma

10 prismatica, Atopos, Tapparone Canefri a)

88 Prosobranchia . . . . . 11,75

26 proteus, Bucciuum, ReEve . . . . . . . . 1

88 Psammobia

9 Pseudochama 30

28 Pseudopeas . . . . . . . . . . . . . 100

28 Pteria . . . . . . . . . . . 13

76 pudibunda, Thalassia, Cox . . . . 81

51 pulchella, Chama, lieveve . . . . . . . . . .

10 pulchellus, Conus, Swainsos . . . . . . 5!!

8 P'ulmonata . . . . . . . . . . . . .

$14 \mid$ Pupa . . . . . . . 100

14 Pupina . . . . . . . . . . . . . .

8. 22 Pupinella . . . . . . . . . . . .

s8 Pupinidae . . . . . . . . . . . . . . . .

30 Purpuridae . . . . . . . . . . 56

33 : Pusia

17 Pyramidella . . . . . . . . . 19

9. 71 Pyramidellidae . . . . . . . . . . . . 4!

59 Pyrula 
quadriradiata, Glyphis, REEve quoyi, Bulla, Grax

radians, l'ectunculus, LAsanch Rathousidace recognita, Chione, E. A. Surn recreana, Chama, Cuessin . reevei, Ameria, doars \& ANgas reflexa, Chama, Reeve regula, Malleus, Forskì reinga, lihagada, GraY responsivus, Microcystis, Heder resticulata, Cytherea, Sowerib reticulata, Voluta, lieEve reticulatus, lithodomus, Dusiker retroversa, Pseudochama, LISCHKE Riliagada.

rhomboides, Telliua, Quor \& Gamand. lihytida

\section{Rhytididae}

richmondiana, Thersites, P'FEIFFER:

Ricinula.

liissoidae

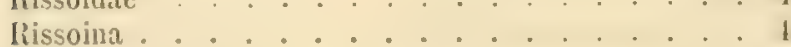

rivularis, Ostrea, (Govid) Liscilke . . . . . 13

robusta, Iupina, Cox

rosacea, Ostrea, Cilemitz.

rubea, Chama, ReEve

rubicunda, Cardita, MENkE

rudis, Planispira, IEDLEY .

rufofulgurata, Oliva, Scuepman

rugosum, Cardium, I A Mrarce .

rugosus, Phacoides, HEdLEY

ruppelli, Glyphis, SowErbX

rustica, Microcystis, Cox

saccharina, Acmaea, LINwé

sanguineus, Janus, ANgas

sarda, Chama, Reeve

Saxicava .

Saxicavidae

scrinta, Circe, IINNÉ. ${ }^{2}$, Oliva, Lamarck ............ . . 11

Scutus

semicastanea, Hadra, Preirter "

seminula, Lucina, Gourd . . . . . . . . . . 21

semitrisulcatus, Potamides, (BoLtes) Miörcir . . . 10)

senticosus, Phos, Linsé . . . . . . . . . 11

septemcostata, Cancellaria, n. sp. . . . . . . . $5 \%$

Septifer . . . . . . . . . . 18

setiger, Pectunculus, n. sp.

sexcostata, Pleurotoma, E. A. SMir

sexraliata, Drillia, u. sp..

sheridani, Rhytida, Brazier.

shuttleworthii, Diplodon, LEA

sibogac, Emarginella, Scherman

sidelia, Oliva, Duclos

Sigaretus

Siliquaria
$+1$

(1)

$26 ;$
30

7.1

$\frac{3 ! 9}{17}$ similis, I'seudochama, n. sp. ............. I' siugaporensis, Glyphis, ReEve . . . . . . . . 11 Siphopatella . . . . . . . . . . . . 47

Sistrum . . . . . . . . . . . . . 51;

Sitala . . . . . . . . . . . . .

sol. Anomia, Reeve . . . . . . . . . . . 11

sordida, Chama, Broverup . . . . . . . . . . . : :1)

Spliaroconia . . . . . . . . . 9s

spinosa, Chama, I3roderip . . . . . . . 2!!

Spondylidae . . . . . . . . 1;

Spondylus . . . . . . . . . . . . . . . .

spurca, Mangilia, Ilsus . . . . . . . . . . . . .

squamatus, l'ecten, Gisels. . . . . . 11

squamigera, Cardita, Desinares . . . . . . . 24

squamosa, Cryptogramma, Lisvé . . . . . . . . 9

» Lima, Lasarck . . . . . . . . . 1:3

* , Tridacua, I Asurack . . . . . . . . \&

squamosus, l'ecten, Grelis . . . . . . . . 11

stellaris, Acmaca saccliarina var., Qcor of Gaisand 3

Stenotropis . . . . . . . . . . . . 9!!

Stomatellidae . . . . . . . . . . . . 1:3

straminea, Avicula, Duskel . . . . . . . . . 17

strangei, Helicarion, l'́reiffer . . . . . . . Ti

Larina, A. ADAMS . . . . . . . 91i

, Rlyytida, P'feiffer . . . . . . . 76

,Trigonia, A. ADAMs ........ 2:3

strangulata, Planispira, Hombrox \& JAcquinot . . 4.

strigillata, Succinea, Adaus \& ANGas ..... 73

strigosa, Gena, A. AdAMS .......... 42

Strombus . . . . . . . 10, is

stroudensis, Endodonta, Cox . . . . . . . . . . .

subdecussata, Venerupis, Desinares ....... . ?

submucronata, Aplanoconia, MöllendorfF . . . gr

subviridis, Cyuraca, lieeve ...... 11, 53

Succillea . . . . . . . . . . . . . . 73

Succineidae . . . . . . . . . 73

sulcaria, P'aphia, Lasarck . . . . . 2 21;

sulcata, Planaxis, Bors . . . . . . . . 11

\, l'yramidella, A. ADAMS . . . . . . 4!

sulphurea, Chama, Reeve . . . . . . . . . . :0

suturalis, Macrochlamys, n. sp. . . . . . . . . 41

, Nassa, Laurarck. . . . . . . . 51

Tapes . . . . . . . . . . . . . . !

Tectibranchia . . . . . . . . . . . . fil

Telescopium . . . . . . . . . . 10

telesconium, Telescopium, Linsé . . . . . 111

Tellina ................ 9.

Tellinidac . . . . . . . . . . . . 26

tenuisculpta, Bulla, n, sp.......... 12

Terebra.............. 11. 5!

Terebralia . . . . . . . . . . 10

Terebridac . . . . . . . . . . . 5?

teres, Pyramidella, A. Adass . . . . . . . 1!

tessclata, Pyrula, Kobelt .......... . 11

tetricus, Craspedochiton, Carrester . . . . . . . T0

tetrix, Tapes, Cuemitz. . . . . . . . . . ?

textile, Conus, LINsË . . . . . . . . . . . . . . .

textilis, Ihos, A. ADass . . . . . . . . . . . . . . . . . 
KUNGI. SV, VET. AKADEMIENS IIANDLINGAR, BAND 52. N:O I6.

textilis, Terebra, HINDs .

Thalassia

Thaumastochiton

'I'hersites

thersites, Cypraea, GAskom

Thylacodes

thyria, Delphinula, ReEv:

tiara, Chione, (DiLlwys) Iieeve

'Tonicia

Tornatellinidae

torresiana, Pleurotoma, E. A. Smitri

tortuosa, Atys, A. ADAMs.

tortus, Mytilus, ReEve

Trachycardium

Trevelyana. . .

tribulus, Murex, LINNÉ

Tridacna .

tridentata, Rissoina, Micraed

'Trigonia.

'Trigoniidae

trilobatum, Ceratosoma, (GRAI) Rocirerrune

Triphora .

'Triton .

Tritonidae

'Tritonidea

Trivia.

'Trochidae

Troclius

truncata, Tonicia, Sowerex _........ l. . . .

tuckeri, Pseudopeas, Pfeiffer . . . . . . . . \& , 10(1)

Tudicla . . . . . . . . . . . . (1)

tumida, Endodonta, n. sp.. .

Turbinellidae

'Timbo

'Turcica

'Turricula

'Turritella

Turritellidae

Tymunatotous:

umbilicata, Hedleya, n. sp.

unguis, Scutus, LiNé

unicolorata, Nassa, Kieser

87

11,50
60 - Unio lag.

$60 \mid$ Unio . . . . . . . . . . . . . . \$1:

81 Unionidae . . . . . . . . . . . .

70 uniophora, Irigonia, GraY . . . . . . . . .:;

11 Vaginula. . .

18 Vaginulidac ....... . . . . . . .

45 Vanikoro ....... dt

26 variabilis, Mucronalia, Schfpmax . . . . . . . $1 !$

12 I varicosa, Drillia, Reeve . . . . . . . . . . .

89 variegata, Cardita, Bruguikre . . . . . . . . 24

8 » Mitra, Reeve . . . . . . . . . 5.1

(1) , Tapes, Sowerri . . . . .

velata, Arca, Sowerer . . . . . . . 21

Veneridae . . . . . . . . 2fi

Venerupis . . . . . 2 26

venosa, Chama, Reeve . . . . . . . . 30

Vermetidae . . . . . . . . . 15

8 Vermetus . . . . . . . . . . tis

3 versicolor, Turbo, Reeve . . . . . . . . .

3 Vertagus. . . . . . . . . . . . 17

1 victoriae, Spondylus, Sowerir . . . . . . . . 8

7 vitrefacta, Ostrea, Sowener . . . . . . . 13

(4) vitreum, Leptopoma, SowEliBY . . . . . . . . 75

11, 49 vitreus, Pectunculus, LaMakck . . . . . . . . . . 22

51 vittata, Mangilia, Hixbs . . . . . . . 58

$5:$ Voluta .............. 12

4.1 volva, Ovula, Linsé . . . 11

Volvaria . . . . . . . . . . 5 5 . .

vulsella, Perna, Lamarck . . . . . . . . 17

wakefieldiae, Elasmias, Cox . . . . . . . . . !

walshii, Crepidula, Hermanisex . . . . . . . 47

( wilcoxi, Sitala, Cox . . . . . . . . . .

4) wilsonii, Diplodon, ILEA. . . . . . . . 71

45 wrightianus, Spondylus, Crosse. . . . . . . .

48 Xanthomelon.............. . . . . .

10 Zebina .............. 4n

zebra, Natica, LAsrarci . . . . . . . . 11;

$75 \gg$, Pteria, Reeve ......... Mi

42 zonata, Delphimula clistorta Lixé, n. rar. . 


\section{Explanation of the Plates.}

\section{Plate 1.}

Fig. 1. Bulla temisculpta n. sp., from aperture. Broome. Nat. size.

2. The same, from behind.

3. The same, another specimen, from behind.

4. Pecten diflormis n. sp., from upper (left) side. Cape Jaubert. $\times$ 2.7.

5. The same from lower (right) side.

6. Pteria (Electroma) zebra ReEve, 2 sps. on Iyjocarpus phoeniceus. Cape Jaubert, 42 miles IV. S. WV. $\times 3.5$.

7. The same, 1 sp. on Phumularia badia. Cape Jaubert, 45 miles $\mathbf{W}$. S. W. X 3.5.

8. The same, 2 sps. on Illumularia balla, one of them with aberrant colouration. Cape Jaubert, 45 miles W. S. W. $\times 3.5$.

1). Perna iutsella LAmarek, right valve from inside, with soft parts (mantle reflected in order to show the gills). Cape Jaubert, 42 miles W. S. W. Nat. size.

- 10. The same specimen, left valve from outside.

- 11. Modiola plumescens Dunker. Cape Jaubert, 42 miles W. S. W. Nat. size.

" 12. Pechnculus vitreus Lamarck, left valve from outside. Cape Jaubert, 46 miles W. S. W. Nat. size. 13. The same specimen, right valve from inside.

14. P'ectunculus setiger n. sp., left valve from outside. Cape Jaubert, 48 miles W. S. W. $\times 1.6$.

15. 'lie same specimen, right valve from inside.

16. Trigonia uniophora Grax, left valve from outside. Cape Jaubert, 42 miles W. S. W. X 2.

17. The same, var, crebrisculpla $n$. left valve from outside. Cape Jaubert, 45 miles W. S. W. $\times 2$.

18. Cardita squamigera DesHayes, left valve from outside. Cape Jaubert, 45 miles W. S. Wr. Nat. size,

19. The same specimen, right valve from inside.

- 20. Ephippodonta granulifera u. sp., left valve from outsicle. Cape Jaubert, 45 miles IV. S. W. $\times 3$.

21. Chione laticostala n. sp., a left valve from outside. Cape Jaubert, 15 miles WV. S. IV.X 1.6.

22. The same, a right valve from inside.

23. Circe plana n. sp., left valve from outside. Cape Jaubert, 45 miles W. S. W. Nat. size.

24. The same specimen, the closed valves seen from the umboes; anterior margin above.

25. The same specimen, right valve from inside.

- 26. Chamostrea plicifera n. sp., left (upper) valve from outside. Cape Jaubert, 42 miles W. S. W. Nat. size.

27. The same specimen, left valve from outside. $\times 2$.

- 24. The same specimen, right (lower) valve from outside. $\times 2$.

29. The same specimen, left valve from inside. $\times 2$.

30. The same specimen, right valve from inside. $\times 2$.

:1. The same, another sp. from Cape Jaubert, 45 miles W. S. W., left valve from inside. $\times 3$.

32. The same specimen, right valve from inside. $\times 3$.

33. Emarginula galericulata A. ADAMS, from above. Cape Jaubert, 45 miles W. S. W. $\times 4.5$.

34. The same specimen from inside. $\times 4.5$.

35. The same specimen from left side. $\times 4.5$. 
Fig. 36. Gena strigosa A. ADas, var. minor n., shell from upper side. Cape Jaubert, 45 miles W. S. W. $\times 3.3$.

37. The same specimen from inside. $\times 3.3$.

\section{Plate :.}

Fig. 38. Euchelus mysticus I'ulsbry. Cape Jaubert, 45 milcs W. S. W. $\times$ 1.6.

39. The same, another sp., from aperture. $\times 1.6$.

10. Delphimula distorta Linse, yar. zonata 11., from above, with two sps. of Crepidula aculcata GseL. Cape Jaubert, 15 miles IV. S. IV. Nat. size.

41. The same, another sp., from aperture.

42. Cerithium (Vertagus) altenuatum Pninsp, var. brevicaudatum n. Cape Jaubert, 45 miles W. S. W. $\times 1.7$.

4:. Cerithiopsis crocea ANGas, var. marmorea n. Cape Jaubert, 45 miles W. S. W. $\times 3.3$.

4.1. Triphora bicincta n. sp. Cape Jaubert, 42 miles W. S. W. $\times 5$.

45. Mucronatia ebumea Desiuyes and M. variabilis SchepMan on an Ophiollrix from Cape Jaubert, 45 miles W. S. W. $\times 4$.

46. Latirus niger n. sp. Cape Jaubert, 45 miles W. S. W. $\times 3.5$.

47. Thos textilis A. ADass. Cape Jaubert, 45 miles W. S. W. $\times 1.7$.

48. Columbella (Mitrella) moleculina DucLos. Cape Jaubert, 42 miles W. S. W. X 6.5.

49. The same, a rose variety from the same locality. $\times 6.5$.

50. Irivia grando Gaskors, from above. Cape Jaubert, 42 miles W. S. W. $\times 3.3$.

51. The same specimen from below. $\times 3.3$.

52. Trivia oryza Lamarck, from above. Cape Jaubert, 45 miles W. S. W. $\times 3.3$.

53 . The same specimen from below. $\times 3.3$.

54. Trivia bipunctata 11 . sp. from above. Cape Jaubert, 42 miles W. S. W. X 3.3.

55. The same specimen from below. $\times 3.3$.

56. Turricula (Pusia) festa ReEve. Cape Jaubert, 42 miles W. S. W. $\times 3.3$.

" 57. Cancellaria septemcostata n. sp. Cape Jaubert, 45 miles W. S. W. $\times 1.7$.

58. Oliva sidelia? Duclos. Cape Jaubert, 45 miles W. S. W. X 2.2.

59. Drillia sexradiata n. sp. Cape Jaubert, 45 miles W. S. IV. $\times 3.5$.

60. Drillia varicosa lievve. Cape Jaubert, 45 miles W. S. W. $\times 3.5$.

61. Drillia hololeuca n. sp. Cape Jaubert, 45 miles W. S. W. $\times 3.5$.

62. Mangilia vittata Hinds. Cape Jaubert, 45 miles WV. S. W. X 3.5 .

63. Terebra eximia Deshayes. Cape Jaubert, 45 miles W. S. W. $\times 2.6$.

64. Terebra columellaris Hinds. Cape Jaubert, 42 miles W. S. W. $\times 2.2$.

65. Terebra textilis Hinds. Cape Jaubert, 45 miles W. S. W. X 2.2.

66. Ceratosoma corallinum 11. sp., from above. Cape Jaubert, 45 miles W. S. W. Nat. size.

67. The same specimen from the right side.

68. Madrella fermiginosa Alder \& Hancock, from above. Cape Jaubert, 45 miles W. S. W. X 3.2.

69 . The same specimen from under side. $\times 3.2$.

70. The same specimen from right side. $\times 3.2$.

71. Doridopsis guttata n. sp. Cape Jaubert, 45 miles W. S. W. $\times 5$.

\section{Plate 3.}

Fig. 72. Endodonta tumida n. sp., from above. Noonkanbah, West Australia. $\times 5$.

- 73. The same specimen from aperture.

"74. The same specimen from below.

"75. Oncis cinerea n. sp. Broome, from above. $\times 2.7$.

" 76 . The same specimen from below,

77. Hedleya unbilicata n. sp. Evelyne, Queensland. $\times 4.5$.

" 78. Pupinella densecostata FurTon. Colosseum, Qucensland. $\times 4.5$.

79. Helicarion bullaceus 3 . sp., animal with shell, from above. I3cllenden Ker, Quecusland. $\times 1.8$.

80. The same specimen, animal with shell from the left. $\times 1.5$.

81. The same, another specimen, shell from aperture. $\times 1.5$.

82. The same, shell from below. $\times 1.5$.

83. Microcystis fulca $\mathrm{n}$. sp., from above. Atherton, Queensland. $\times 2.0$. 
Fig. 81. The same, from aperture. $\times 2.6$.

" 85. The same, from below. $\times 2.6$.

86. Macrochlamys suturalis 11. sp., from above. Malanda, Qucensland. $\times 1.5$.

87. The same specimen, from aperture. $\times 1.5$.

" 88. 'l'he same specimen, from below. $\times 1.5$.

- 89. Flammelina cumulus n. sp., from above. Iielienden lier, (Queensland. X 3.3 .

90. The same specimen from aperture. $\times 3.3$.

91. The same specimen from below. $\times 3.3$.

92. Endodonta intermedia n. sp., from aperture. Cedar Creek, Quecnsland. X 8.

93. The same specimen from below. $\times 8$.

94. Chloritis bilabiata 11. sp., from above. Malanda, Queensland. X 2.5.

- 95. The same specimen from anerture. $\times 2.5$.

v 96. The same specimen from below. $\times 2.5$.

97. Thersites castanca n. sp., from aperture. Queensland. Nat. size.

98. The same specimen from below.

\. 99. Atopos (Prisma) australis? Hevnesas, from below. Herberton, queensland. $\times 1.5$.

100. The same specimen from above. $\times 1.5$.

- 101. Planispira prachadra n. sp., from above. Chillagoe, (queensland. Nat. size.

: 102. The same specimen from aperture.

103. T'he same specimen from below.

- 104. Microcystis antiqua n. sp., from above. Chillagoe, Queensland. $\times 3$.

"105. The same from aperture. $\times 3$.

106. The same from below. $\times 3$.

- 107. IIypsclostoma australis 11. sp., from above. Clillagoe, (Juecnsland. $\times 10$.

108. The same, another specimen, from aperture. $\times 10$.

109. The same, another specimen, from helow. $\times 10$.

\$110. Aphanoconia extincta 11. sp., from above. Chillagoe, Queensland. $\times 3$ :

* 111. The same specimen from aperture. $\times 3$.

112. The same specimen from below. $\times 3$.

-113. Omphalotropis mimuta n. sp., from aperture. Chillagoe, Queensland. $\times 10$.

"114. The same specimen from below. $\times 10$.

"115. Microphyuera microdiscus Baray, from above. Chillagoe, Queensland. $\times 10$.

- 116. The same, another specimen from aperture. $\times 10$.

\$ 117. The same a third specimen; outer wall broken in order to show the parictal teeth. $\times 10$.

-118. The same, a specimen from below. $\times 10$.

\section{Postscript.}

While the last sheets of this publication were going through the press, I received a letter from Mr. Cr. Heder in reply to my question, as to whether Mlicrophlyera microdiscus from Chillagoe, of which I had sent a specimen for comparison, was identical with $M$. hemicleusa of TATE. Mr. Heder informs me that the identity of these forms has already been established by Funton (Ann. Mag. Nat. Hist. 8, XIV, Aug. 1914, p. 164, and Proc. Malac. Soc. XI, 1915, p. 236), who has also erected the genus Stenopylis for the reception of the species, which, consequently, should be named Stenopylis hemiclausa (TaTE). 


\section{Contonts.}

Pag.

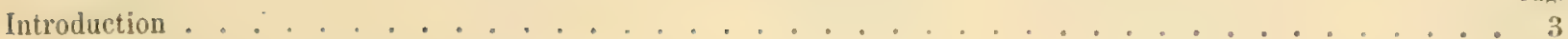

A. Marine Mollusca . . . . . . . . . . . . . . . . . . . . 7

1. Mollusca from the shores of Broome. . . . . . . . . .

2. Mollusca from the Pearl Banks off Cape Jaubert. . . . . . . . . . . . . . . . . 13

a. Lamellibranchia . . . . . . . . . . . . . . . 13

Survey of the Anatomy of Chamidac . . . . . . . . . . . . . . . . . . 31

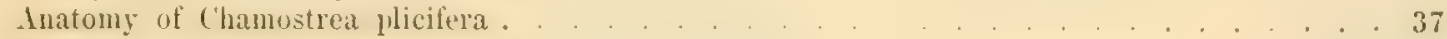

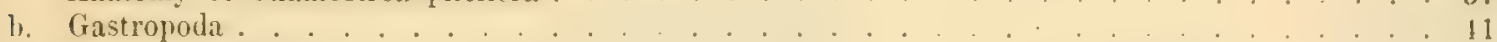

Prosobranchia . . . . . . . . . . . . . . . . . . . . 41

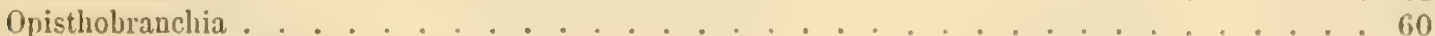

Anatomy of Madrella ferruginosa. . . . . . . . . . . . . . . . . 65

॰. Cephalopoda . . . . . . . . . . . . . . . . . . . . . . 70

d. Amphineura. . . . . . . . . . . . . . . . . . 70

3. Mollusca from the sliores of Queensland . . . . . . . . . . . . . . . . . . . 71

1). Land and Fresh-water Molluscir . . . . . . . . . . . . . . . . . . . . . 7:?

1. From West-Australia . . . . . . . . . . . . . . . . . . . . . . 72

2. From Queensland (and South Australia) . . . . . . . . . . . . . . . . 75

a. Operculate land mollusca (Prosobranchia) . . . . . . . . . . . . . . . . . . 75

b. Inoperculate land mollusca (Pulmonata) . . . . . . . . . . . . . . . . . 76

General Remarks on the Species of Mricrocystis . . . . . . . . . . . . . . 79

Anatomy of Atopos australis. . . . . . . . . . . . . . . . . . . . 91

3. Subfossil mollusca from the caves at Chillagoe . . . . . . . . . . . . . . . . 97

List of Worlis referred to . . . . . . . . . . . . . . . . . . . . . . . . . . .

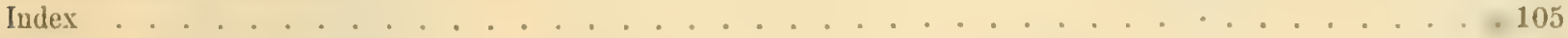

Explanation of tle Plates . . . . . . . . . . . . . . . . . . . . . . . .

Tryckt den 19 septembor 1917.

Uppsala 1917. Almǫrist \& Wiksells Boktrgekeri-A.-B. 

K. SVENSKA VETENSKAPSAKADEMIENS HANDLINGAR. Band 52. N:o 16.

Pl. 1.
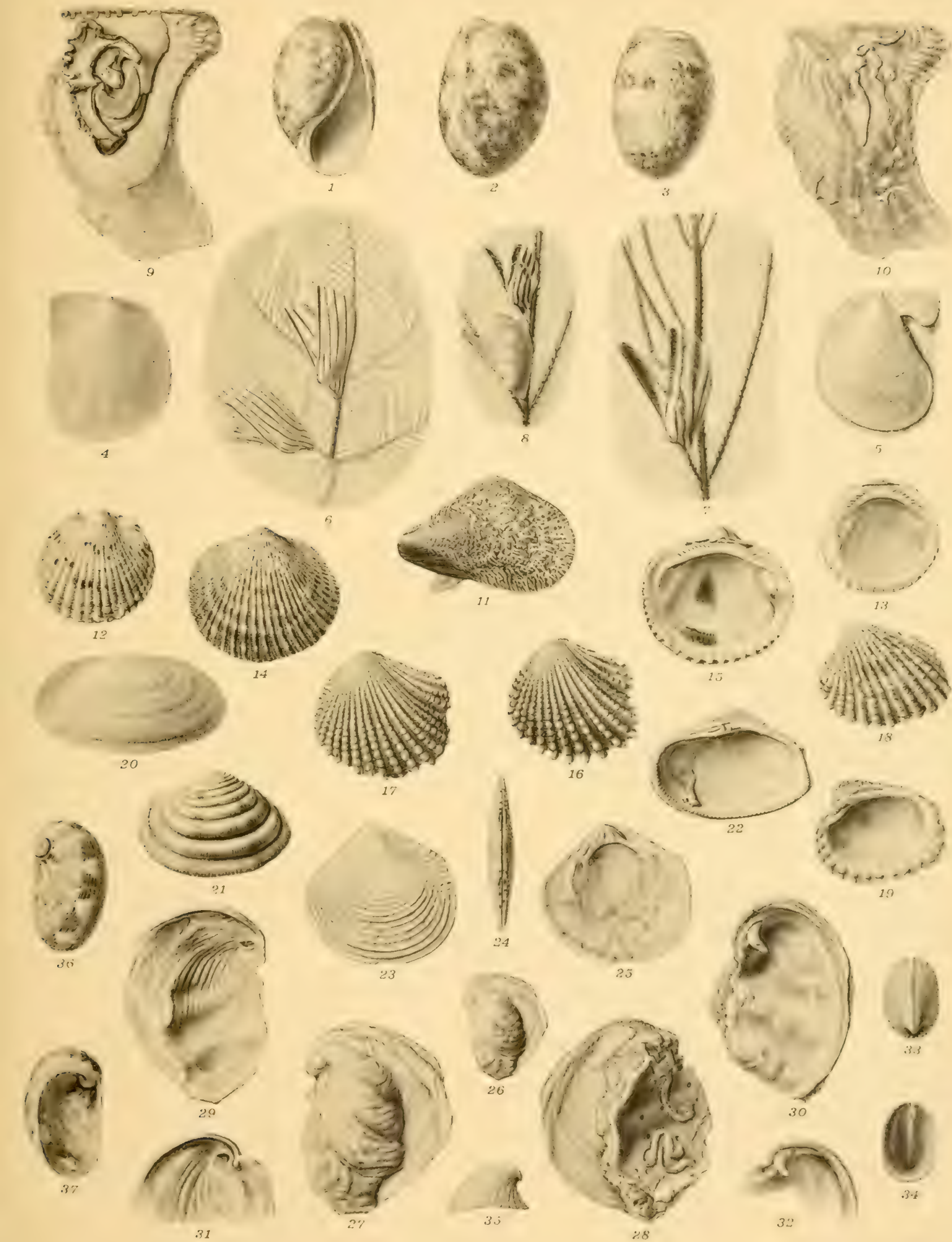

N. Odhner phot. G. Liljevald ret. et del.
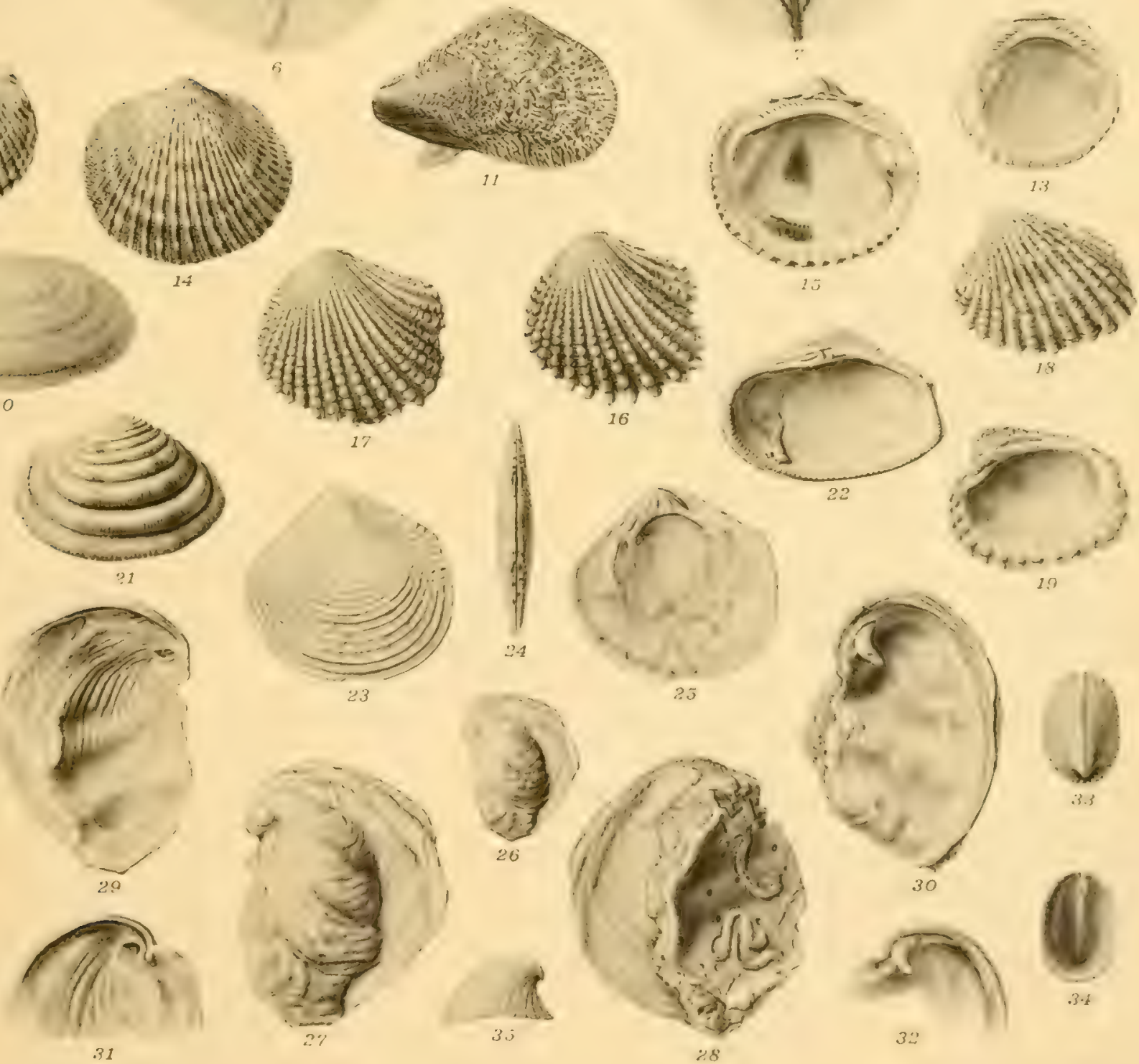


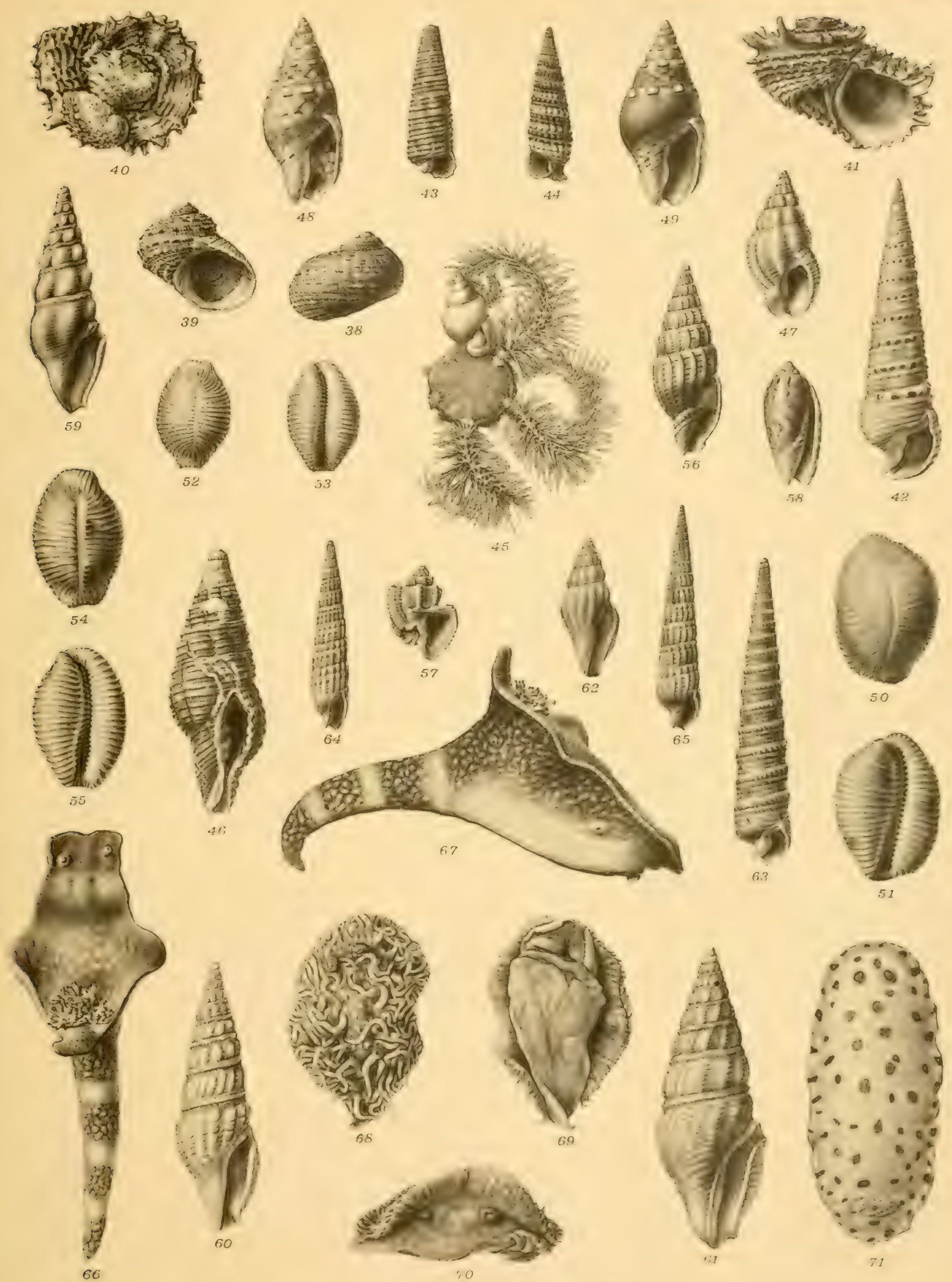

N. Odhner phot. el del. G. Liljevall ret. et del. 

K. SVENSKA VETENSKAPSAKADEMIENS HANDLINGAR. Band 52, N:0 16,

PI. 3.
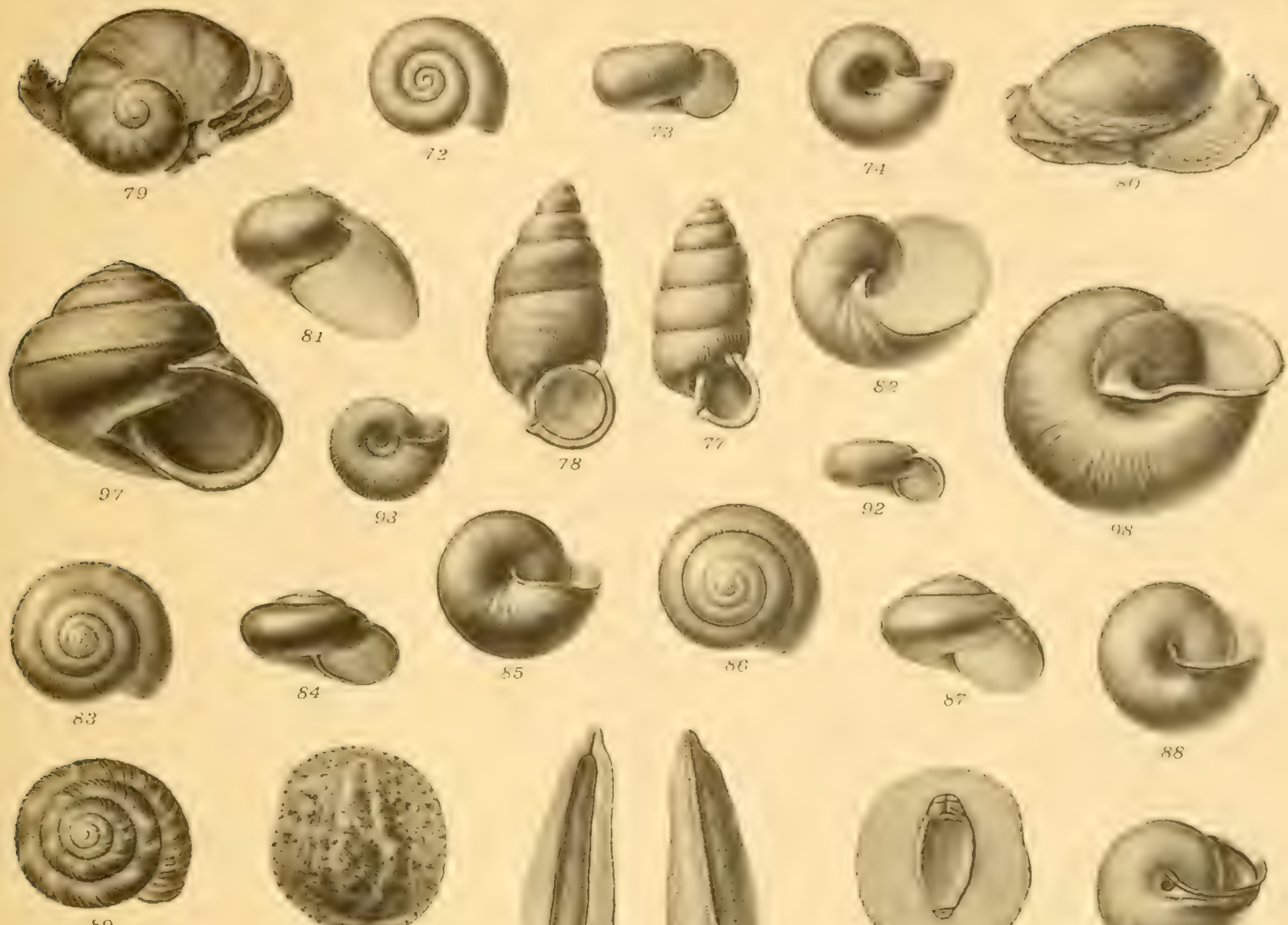

49
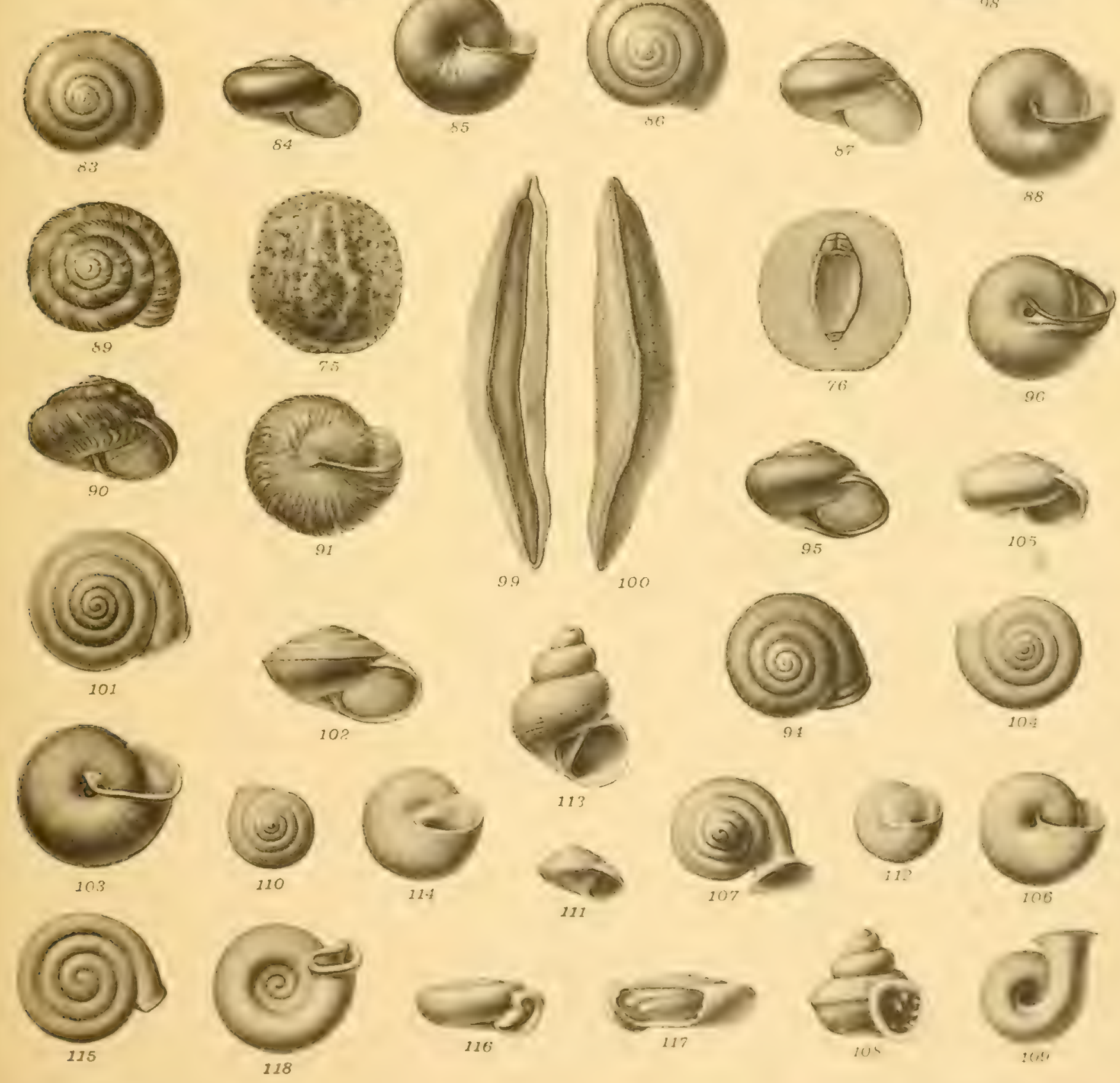

N. Odhner phot. G. Liljevall ret. 








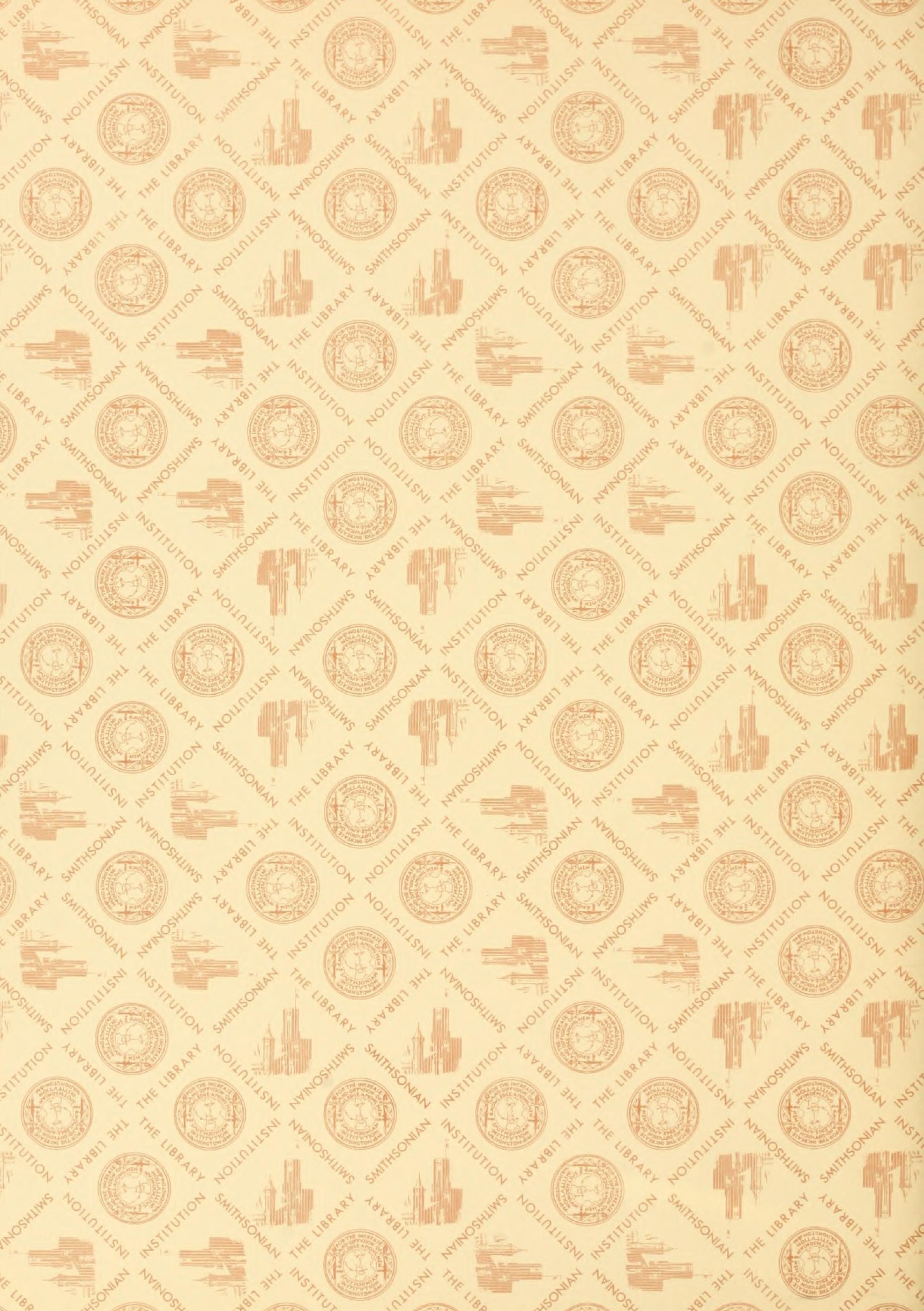




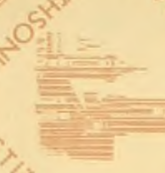

(ca)

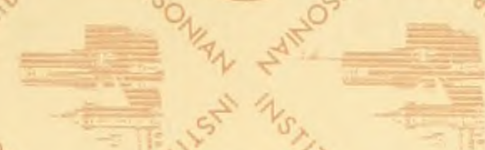

10

$=$

$y=$
the
th
(c)

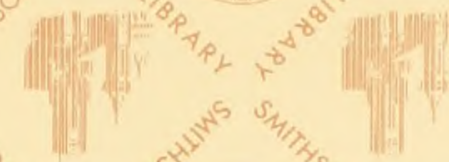

(c) (O)

(19)

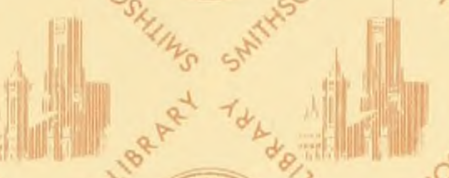

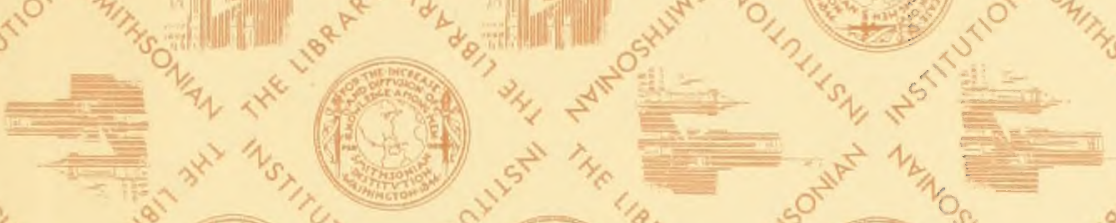

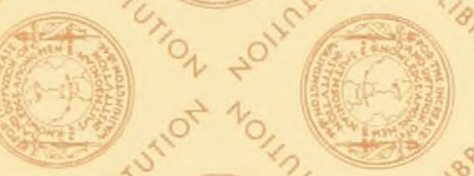

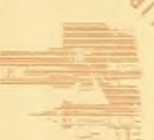
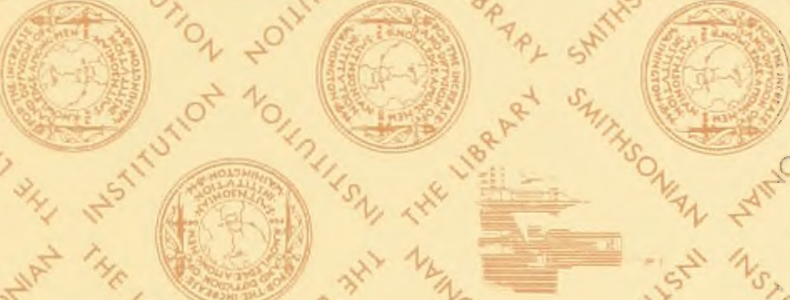

$(4-5)$

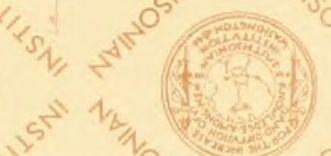

$\left(\frac{2}{3}\right)$

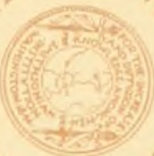
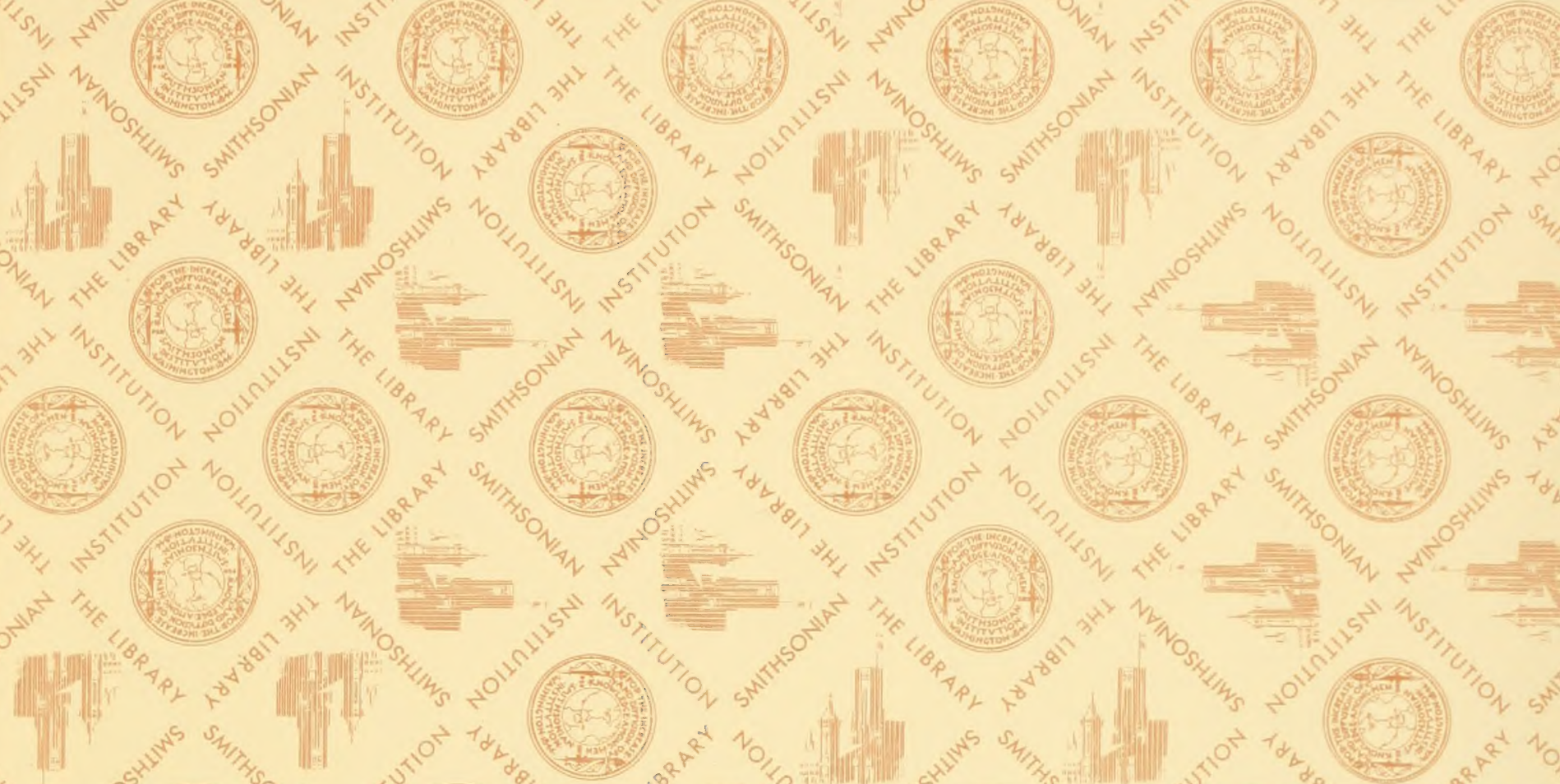

(Cst

(a)

(iㅣㄴ.

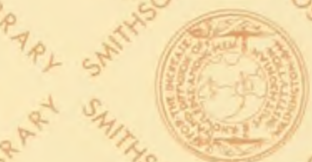

(is)

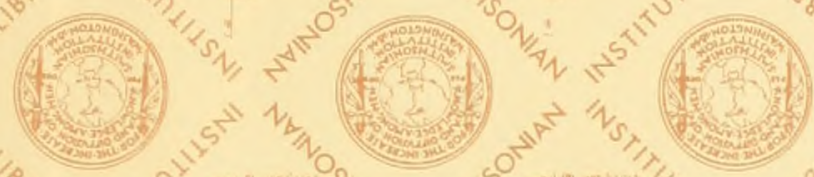
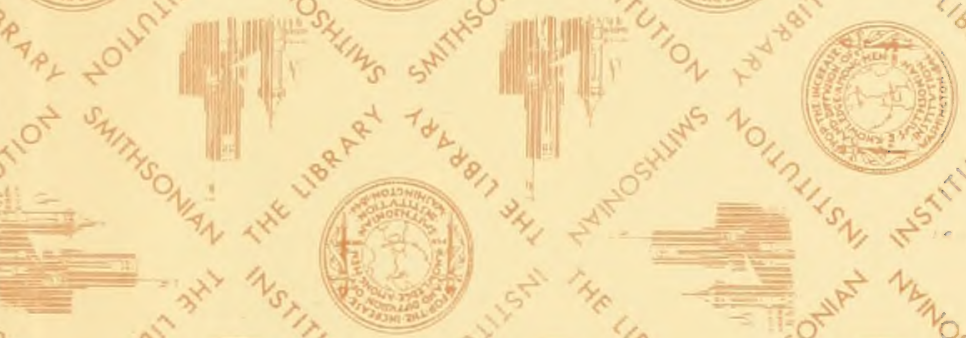

it (i)
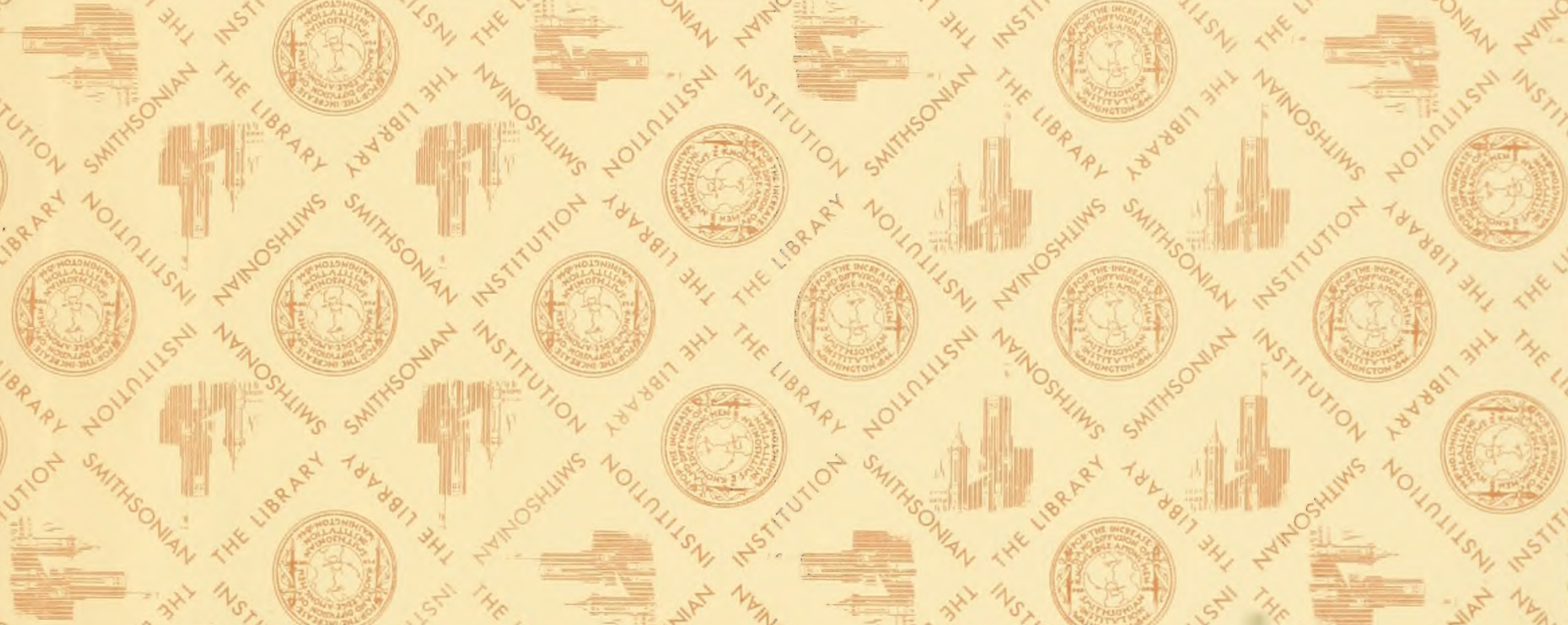

(1)|
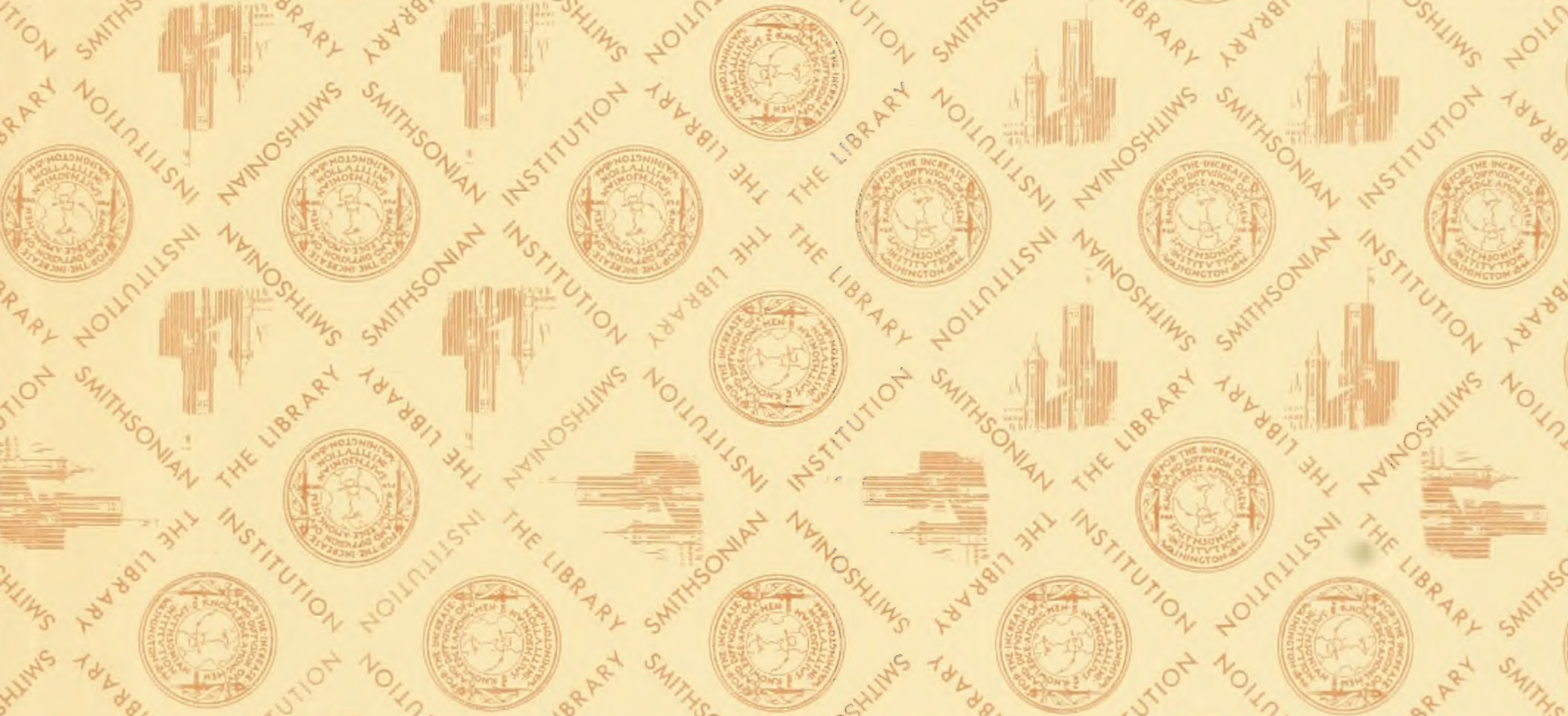

I.t.
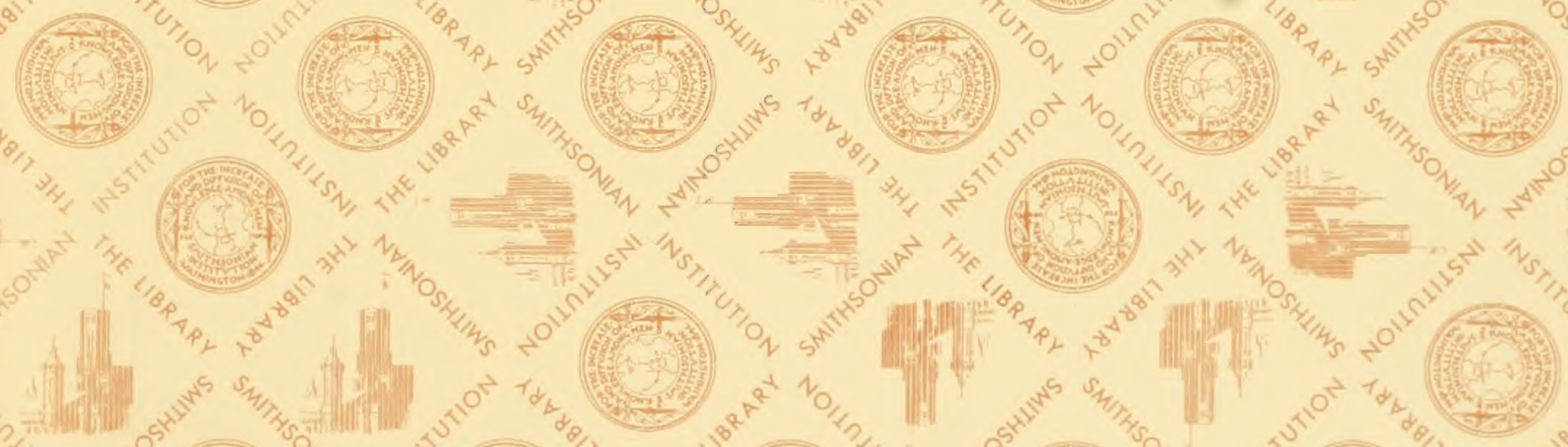

(39)
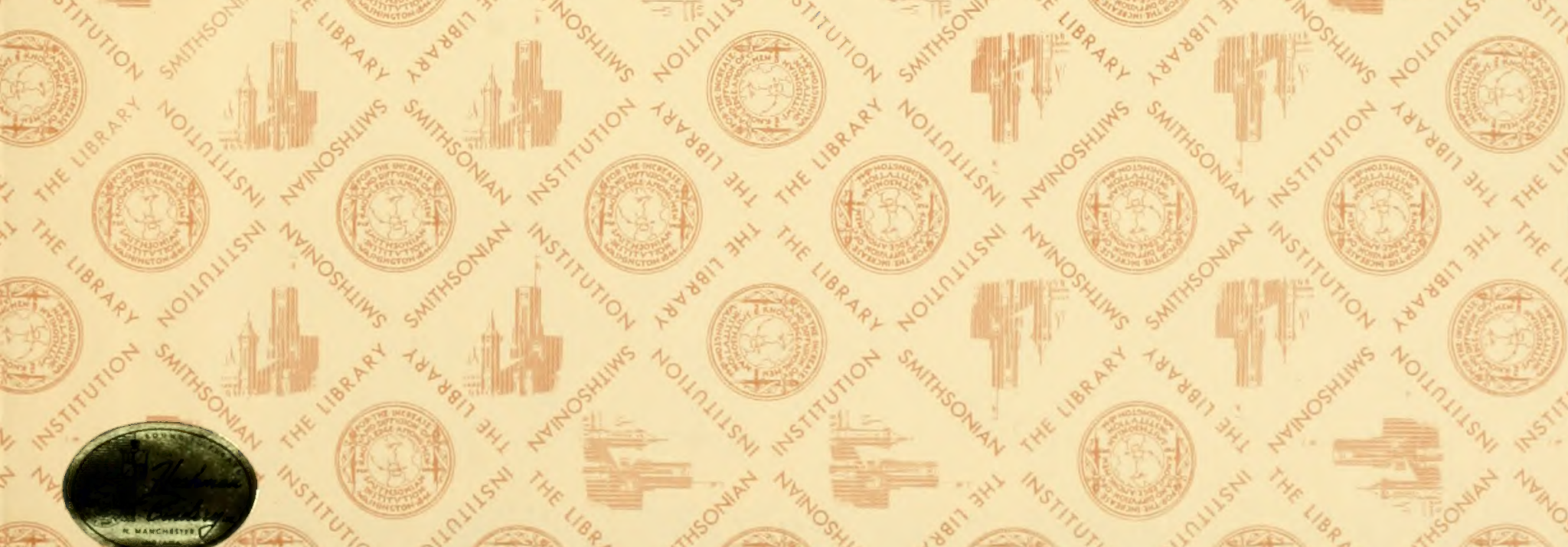

(2)
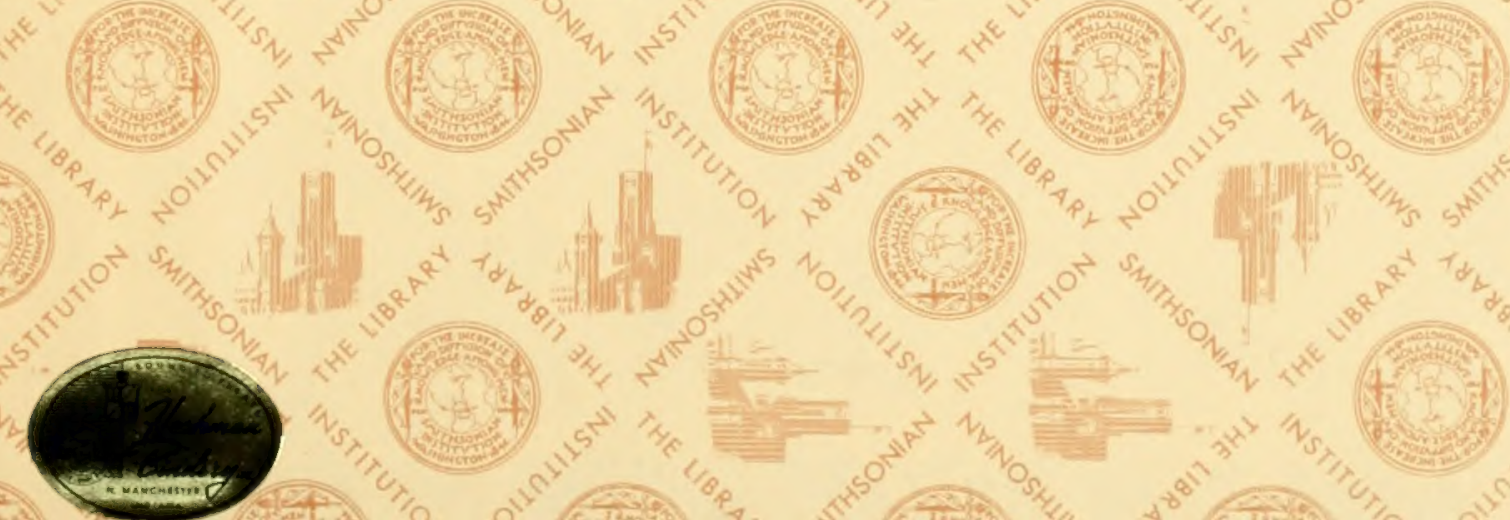

$\left(\frac{1}{3}-5\right)$$$
x^{n}+4
$$ 
